\title{
Updated catalogue of bony fishes observed in deep waters at Isla del Coco National Park and Las Gemelas Seamount, Costa Rica (Eastern Tropical Pacific)
}

\author{
Astrid Sánchez-Jiménez ${ }^{1}$, Beatriz Naranjo-Elizondo ${ }^{1,2}$, Alexander Rodríguez-Arrieta ${ }^{3}$, \\ Andrés J. Quesada ${ }^{1}$, Shmulik Blum ${ }^{4}$, John E. McCosker ${ }^{5}$, D. Ross Robertson ${ }^{6}$, Peter J. Auster ${ }^{7,8}$ \\ \& Jorge Cortés ${ }^{1,2 *}$ \\ 1. Centro de Investigación en Ciencias del Mar y Limnología (CIMAR), Ciudad de la Investigación, Universidad de \\ Costa Rica, San Pedro, 11501-2060 San José, Costa Rica; astrid.sanchez@leibniz-zmt.de, beanaranjo@gmail.com, \\ quesadacr@gmail.com; jorge.cortes@ucr.ac.cr \\ 2. Escuela de Biología, Universidad de Costa Rica, San Pedro, 11501-2060 San José, Costa Rica. \\ 3. Centro de Investigación en Estructuras Microscópicas (CIEMic), Ciudad de la Investigación, Universidad de Costa \\ Rica, San Pedro, 11501-2060 San José, Costa Rica; bioalrod@gmail.com \\ 4. DeepSee, UnderSea Hunter Group, San José, Costa Rica; shmulikbl@underseahunter.com \\ 5. California Academy of Sciences, San Francisco, California 94118, USA; jmccosker@calacademy.org \\ 6. Instituto Smithsonian de Investigaciones Tropicales, Balboa, República de Panamá; drr@stri.org \\ 7. Mystic Aquarium - Sea Research Foundation, 33 Coogan Blvd., Mystic, Connecticut 06355, USA; \\ peter.auster@uconn.edu \\ 8. University of Connecticut, Department of Marine Sciences, 1080 Shennecossett Rd., Groton, Connecticut 06340 USA \\ * Correspondence
}

Received 30-V-2018. Corrected 13-VIII-2018. Accepted 31-VIII-2018.

\begin{abstract}
From 2006 to date the submersible DeepSee has been used to study the deep waters in and around Isla del Coco National Park, Costa Rica. Over these years, images and samples have been collected at depths between 50 and $450 \mathrm{~m}$. Here we present a catalogue of bony fishes recorded by the submersible in deep waters of Isla del Coco, $500 \mathrm{~km}$ south-southwest of mainland Costa Rica, and at Las Gemelas Seamount within the designated Seamounts Management Area, $50 \mathrm{~km}$ southwest of Isla del Coco. A database with video-images of bony fishes was created from videos taken by the submersible's high-definition digital camera from 2006 to 2015 . Additional information on the distribution of fishes was obtained from 11 dives $(24.3 \mathrm{hrs})$ using the remotely operated vehicle Hela at Las Gemelas Seamount during February 2012. Images of bony fishes were obtained during 376 dives (365 DeepSee dives plus 11 Hela dives) in 18 different locations, and here we report on a total of 85 taxa (i.e. putative species). In this catalogue we present images that are the first color photographs published for some species. In other cases, identifications were possible only to the level of genus (11), family (5) or order (1); hence the information is presented in terms of putative taxa. Four new records are reported for Isla del Coco: Leptenchelys vermiformis (Ophichthidae), Hyporthodus mystacinus (Serranidae), Kathetostoma averruncus (Uranoscopidae), and Symphurus diabolicus (Cynoglossidae). Depth ranges of twenty-six species are expanded beyond previously published records; three were observed in shallower water, twenty-two in deeper water and one was observed both shallower and deeper than in previous reports. As might be expected, increased bottom time with the submersible resulted in additions to the list of documented species. This highlights the importance of maintaining systematic research efforts in the deep waters around Isla del Coco, both for scientific purposes as well as conservation.
\end{abstract}

Key words: Deep-water fishes; marine biodiversity; Cocos Island; DeepSee; ROV; submersible research.

Sánchez-Jiménez, A., Naranjo-Elizondo, B., Rodríguez-Arrieta, A., Quesada, A. J., Blum, S., McCosker, J. E., Robertson, D. R., Auster, P. J., \& Cortés, J. (2018). Updated catalogue of bony fishes observed in deep waters at Isla del Coco National Park and Las Gemelas Seamount, Costa Rica (Eastern Tropical Pacific). Revista de Biología Tropical, 66(Supplement 5), S1-S113. 
Isla del Coco is the only section of the Coco Volcanic Submarine Range (Cordillera Volcánica Submarina del Coco) that emerges above sea level (Rojas \& Alvarado, 2012), reaching a height of over $2500 \mathrm{~m}$ above the ocean floor (Lizano, 2012), and $575 \mathrm{~m}$ above sea level (Montoya, 2016). The island is a hotspot of biological diversity in the Eastern Tropical Pacific, with at least 1688 marine species reported (Cortés, 2012) and with the highest number of endemic marine species in Costa Rica (Wehrtmann, Cortés, \& Echeverría-Sáenz, 2009; Cortés, 2012). Although the shallowwater marine biodiversity of Isla del Coco has been well studied and documented (Cortés, 2008), there are still unexplored regions with large potential for discovery, such as deep ocean zones (Cortés, 2012, 2016).

The waters of Isla del Coco are totally protected from fishing within the area designated as a National Park whereas Las Gemelas Seamount is subject to fishing pressure within a Seamounts Management Area; however, illegal fishing is recognized as a major threat (Soto, 2014; López-Garro, Zanella, Martínez, Golfín-Duarte \& Pérez-Montero, 2016). Since 2006 the submersible DeepSee has been used to study waters between 50-450 m depth at Isla del Coco (Cortés \& Blum, 2008), and more recently at depths between 167-311 $\mathrm{m}$ at Las Gemelas Seamount, $50 \mathrm{~km}$ southwest of the island (Lizano, 2012). The use of DeepSee has led to a series of investigations into deeper areas that address multiple topics: diversity and associated marine environments (Cortés \& Blum, 2008; Starr, Cortés, Barnes, Green, \& Breedy, 2012a; Starr, Green, \& Sala, $2012 b$ ), reproductive behavior of fish (Erisman, Konotchick, \& Blum, 2009), imaging of new fish species (Bussing, 2010; McCosker \& Rosenblatt, 2010; Poss, McCosker, \& Baldwin, 2010), first reports of range extensions for bony fish species (Angulo, Naranjo-Elizondo, Corrales-Ugalde \& Cortés, 2014), first reports of elasmobranchs (Long, McCosker, Blum, \& Klapfer, 2011; Cortés et al., 2012), quantitative sampling of fish communities (Starr et al., $2012 b$ ), and the first report of group hunting by piscivores in deep-water communities (Auster et al., 2016). There are also publications on invertebrates: a description of a new family of octocorals (Breedy, Van Ofwegen, \& Vargas, 2012), diversity and abundance of invertebrates (Starr et al., 2012a), descriptions of new gastropod species (Owen \& Reitz, 2012), and reports of gelatinous zooplankton (Corrales-Ugalde, Quesada, Naranjo-Elizondo, \& Cortés, 2017). Also, the DeepSee acquired images of anthropogenic debris deposited in the deep waters of Isla del Coco, where mainly plastic litter from fishing gear can be found (Naranjo-Elizondo \& Cortés, 2018).

Isla del Coco has 514 reported species of bony fishes, of which 72 are limited to deep zones $(>50 \mathrm{~m})$ as defined by Fourriére, Alvarado, Bocos, and Cortés (2017). Most of fish diversity known so far at Isla del Coco is associated with shallow coral reefs (Fourriére et al., 2017), one of the most threatened ecosystems around the world due to global change and human activities (Hughes et al., 2017). Mesophotic coral reefs, occurring from 30 to $150 \mathrm{~m}$ (Hinderstein et al., 2010) are recognized to be distinct from shallow reefs and have been proposed to offer refuge for many shallow species able to survive in deeper areas (Baldwin, Tornabene, \& Robertson, 2018). However, mesophotic reefs are also impacted by human activities and their recovery might take more time (Rocha et al., 2018). Since conservation efforts are usually focused on shallow waters, the protection of deeper ecosystems should be a priority in marine conservation in order to protect both shallow and deep reef species (Rocha et al., 2018). Recently, Baldwin et al. (2018) proposed a classification for fishes differentiating between the altiphotic ( 0 to $\sim 40 \mathrm{~m})$, mesophotic $(\sim 40$ to $\sim 130 \mathrm{~m})$ and rariphotic $(\sim 130$ to $\sim 300 \mathrm{~m}$ ) zones, which are defined according to the amount of light present (from high in the altiphotic to scarce in the rariphotic). Since the mesophotic zone can provide refuge for altiphotic species, so can the rariphotic zone for the mesophotic (Baldwin et al., 2018). Therefore, studies on depth boundaries and species composition in each depth region can 
provide information for the conservation of many fishes.

As a baseline for future studies, here we present a catalogue of deep-water species of Isla del Coco and Las Gemelas Seamount (50-450 m depth), recorded by the submersible DeepSee and ROV (remotely operated vehicle) Hela, the latter has been used only at Las Gemelas and is a technology not yet employed for the exploration of Isla del Coco National Park. We included images, descriptions and distributions of 85 deep-water fish species, some of which had not been previously reported for the island, and others are imaged alive in the field for the first time in color.

\section{MATERIALS AND METHODS}

Dives were conducted at 18 different locations (15 sites around Isla del Coco National Park and three at Las Gemelas Seamount) between 2006 and 2015 (Table 1, Fig. 3). The places most frequently sampled were Everest and The Wall 475, with the least frequent being Canyons and Banana (Table 1, Fig. 3). A total of 365 dives of the DeepSee submersible were analyzed. DeepSee is a three-person submersible with capability to dive to $450 \mathrm{~m}$, equipped with a high definition camera placed outside (Fig. 1; see Cortés \& Blum, 2008 for more details); MV Argo serves as the support ship (Fig. 2). Prior to 2013 videos were recorded with an AVI format on mini-DVC tapes with a Sony FX1 and from 2013 to 2015 with a Sony High Definition HXR-NX70U. The videos were transcoded with a 4:2:2 low codec to a .mov format. Image-captures of fishes were made in the laboratory with iMovie and FinalCut software and linked to information (e.g., location, depth, dive time) collected during each dive from 2006-2015. Observations of fishes were not made systematically because the submersible is used mainly for tourism; however, since the recordings are usually focused on large and conspicuous animals, the icthyofauna is well represented in the videos. Each DeepSee dive lasted approximately two hours; however, since observation periods

TABLE 1

List of diving sites where the submersible DeepSee (2006-2015) and ROV Hela* (2012) had explored the deep waters at Isla del Coco National Park and Las Gemelas Seamount, Costa Rica

\begin{tabular}{|c|c|c|c|c|c|}
\hline \multirow{2}{*}{ Site } & \multirow{2}{*}{ Number of dives } & \multirow{2}{*}{ Latitude $(\mathrm{N})$} & \multirow{2}{*}{ Longitude (W) } & \multicolumn{2}{|c|}{ Depth (m) } \\
\hline & & & & Minimum & Maximum \\
\hline 1. Argo 2 & 4 & $05^{\circ} 35.244^{\prime}$ & $87^{\circ} 02.848^{\prime}$ & 180 & 205 \\
\hline 2. Kili Rock & 5 & $05^{\circ} 34.903^{\prime}$ & $87^{\circ} 03.400^{\prime}$ & 220 & 220 \\
\hline 3. The Edge & 5 & $05^{\circ} 34.920^{\prime}$ & $87^{\circ} 03.161^{\prime}$ & 200 & 300 \\
\hline 4. Kili 2 & 17 & $05^{\circ} 35.006^{\prime}$ & $87^{\circ} 03.141^{\prime}$ & 160 & 180 \\
\hline 5. The Wall 475 & 104 & $05^{\circ} 34.753^{\prime}$ & $87^{\circ} 03.504^{\prime}$ & 200 & 450 \\
\hline 6. Piedra 165 & 25 & $05^{\circ} 34.670^{\prime}$ & $87^{\circ} 03.473^{\prime}$ & 150 & 170 \\
\hline 7. Kili & 7 & $05^{\circ} 34.703^{\prime}$ & $87^{\circ} 03.400^{\prime}$ & 130 & 170 \\
\hline 8. Piedra Drop & 50 & $05^{\circ} 34.640^{\prime}$ & $87^{\circ} 03.557^{\prime}$ & 180 & 300 \\
\hline 9. Banana & 1 & $05^{\circ} 34.497^{\prime}$ & $87^{\circ} 03.606^{\prime}$ & 225 & 225 \\
\hline 10. Canyons & 1 & $05^{\circ} 34.383^{\prime}$ & $87^{\circ} 03.909^{\prime}$ & 308 & 308 \\
\hline 11. Boulders & 5 & $05^{\circ} 34.267^{\prime}$ & $87^{\circ} 03.818^{\prime}$ & 250 & 311 \\
\hline 12. Everest & 117 & $05^{\circ} 33.950^{\prime}$ & $87^{\circ} 02.862^{\prime}$ & 45 & 90 \\
\hline 13. Bajo Manuelita & 10 & $05^{\circ} 33.741^{\prime}$ & $87^{\circ} 02.715^{\prime}$ & 40 & 65 \\
\hline 14. Arena & 2 & $05^{\circ} 33.732^{\prime}$ & $87^{\circ} 02.232^{\prime}$ & 110 & 110 \\
\hline 15. The Arch & 6 & $05^{\circ} 29.076^{\prime}$ & $87^{\circ} 05.144^{\prime}$ & 60 & 90 \\
\hline 16. Las Gemelas 1 & 3 & $04^{\circ} 59.153^{\prime}$ & $87^{\circ} 26.472^{\prime}$ & 250 & 250 \\
\hline 17. Las Gemelas 2 & 1 & $04^{\circ} 59.120^{\prime}$ & $87^{\circ} 26.410^{\prime}$ & 170 & 200 \\
\hline 18. Las Gemelas 3 & $2+11^{*}$ & $05^{\circ} 04.851^{\prime}$ & $87^{\circ} 38.525^{\prime}$ & 163 & 261 \\
\hline
\end{tabular}




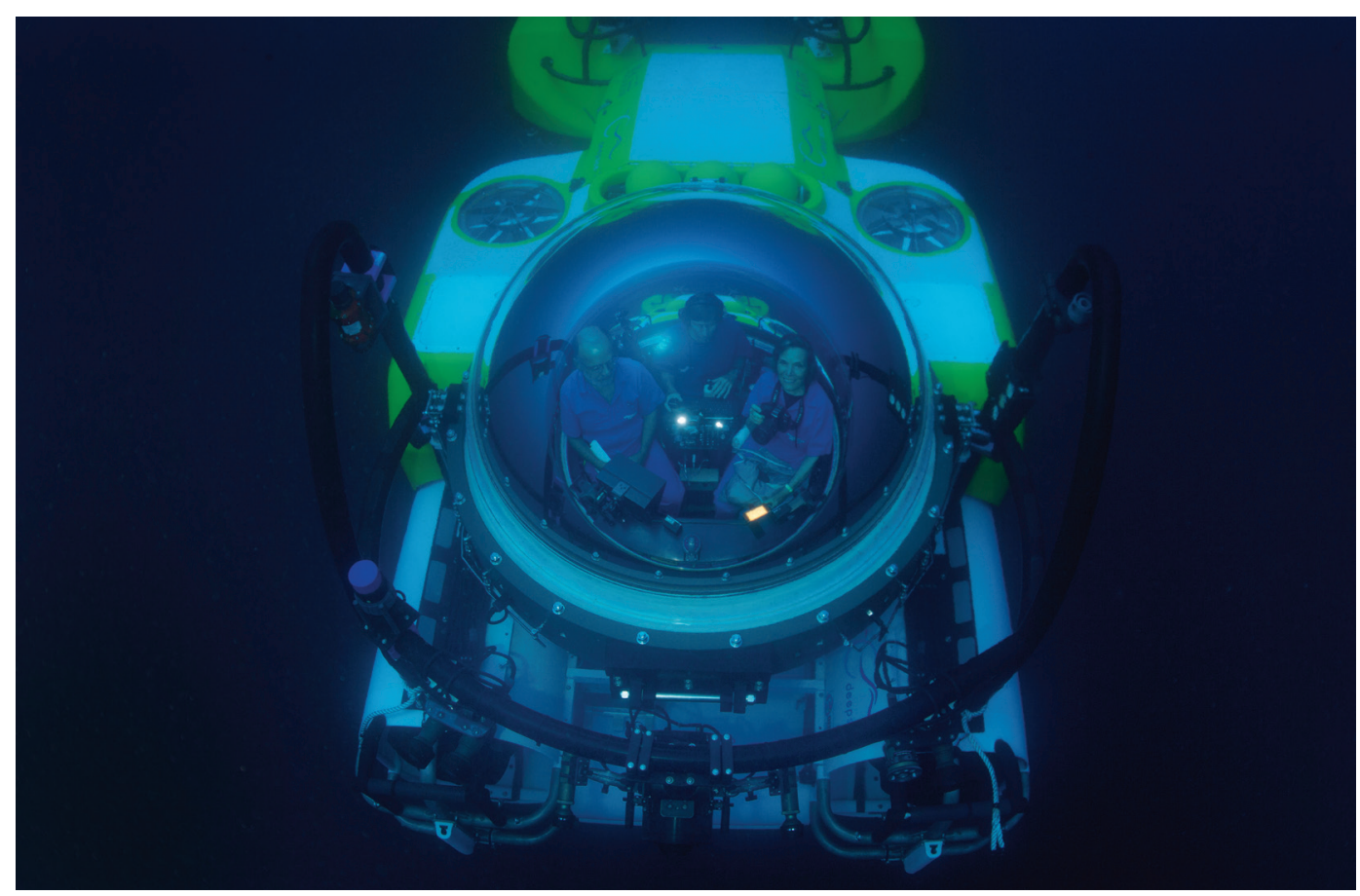

Fig. 1. DeepSee submersible with the pilot in the back and two persons in the front. Photograph by Kip Evans.

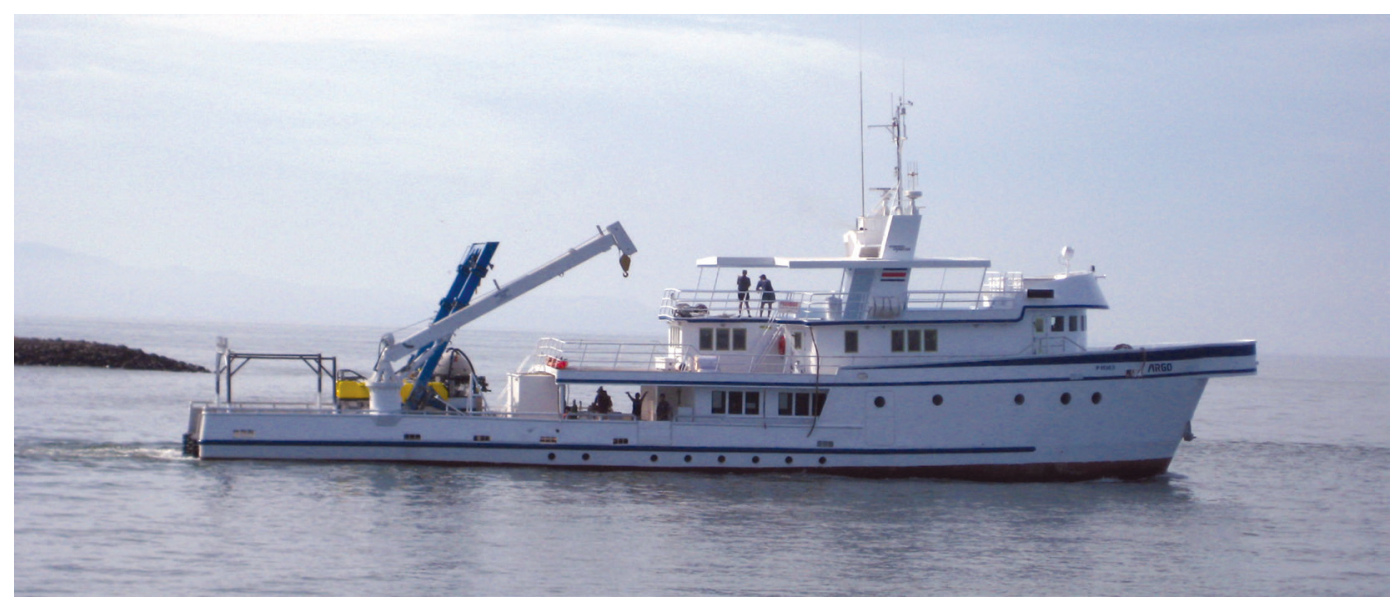

Fig. 2. DeepSee mothership MV Argo. (Reproduced with permission from Revista de Biología Tropical, Vol. 56, Suppl. 2, page 192). Photograph by Jenaro Acuña-González.

were not made systematically, we measure the sampling effort based on the number of dives and not on their duration. Additionaly, 11 dives (24.3 hrs) with the ROV Hela were conducted at Las Gemelas Seamount in February 2012 (Table 1, see Auster et al., 2016 for details). Hela carried a Kongsberg OE 14-502A HD (1080i) video camera and sent video in real time to the surface via an HDSDI signal over fiber-optic with image captures of fishes made directly using BTV Pro software. Video was translated to an analog signal and recorded to DVD. 


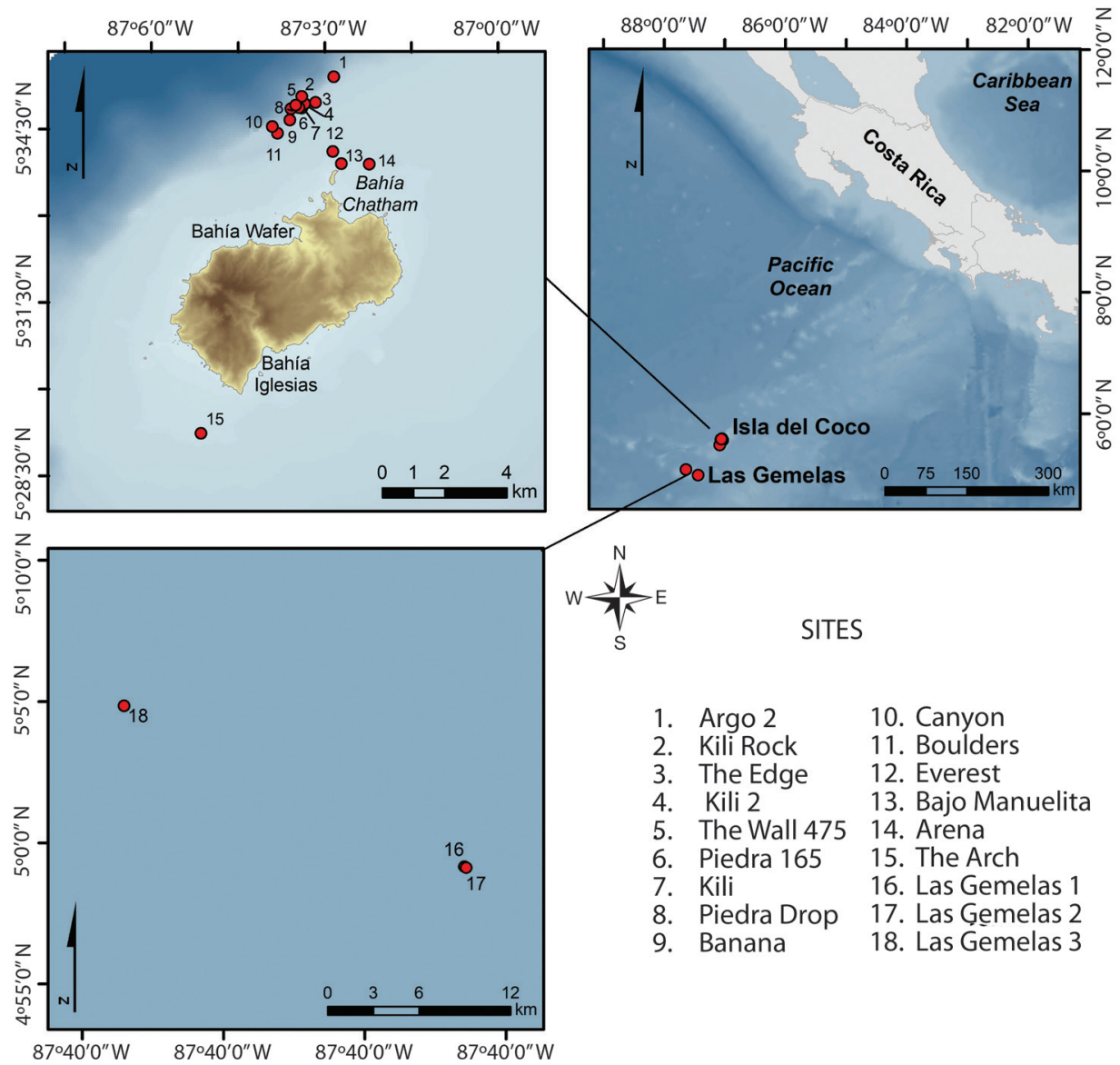

Fig. 3. Location of sites at Isla del Coco National Park and Las Gemelas Seamount where the submersible DeepSee and ROV Hela acquired video of bony fishes. Maps generated with topographic data from the Instituto Geográfico Nacional (Costa Rica) and bathymetric data provided by Omar Lizano.

Images of every species are included in the Appendix, with a brief description of the species, its local and global distribution, details of the observations at Isla del Coco and Las Gemelas (location, depth, date and time of day) and previous reports at either location. A list of these taxa is presented in Table 2 in a phylogenetic sequence following Nelson (2006) and Page et al. (2013). Within each family, species are arranged alphabetically using valid names according to Eschmeyer, Fricke, and van der Laan (2017). Common names are given in both English and Spanish, according to Page et al. (2013) if the species was included in that work, otherwise following the common names used in Robertson and Allen (2015). The depth range of occurrence is shown for each specific locality as the minimum and maximum depth where the species was recorded. Previous reports and comments (in some cases) are also included for each taxa. The underwater vehicles used in this study are not equipped to capture specimens, thus all the fishes were visually identified to the minimum taxonomical level possible. We used for the identification: Fischer et al. (1995), Bussing and López (2005, 2009), Garrison (2005), Cortés and Blum (2008), Erisman et al. (2009), Bussing (2010), McCosker and Rosenblatt (2010), Poss, McCosker, and Baldwin (2010), Starr et al. (2012b); Robertson and 


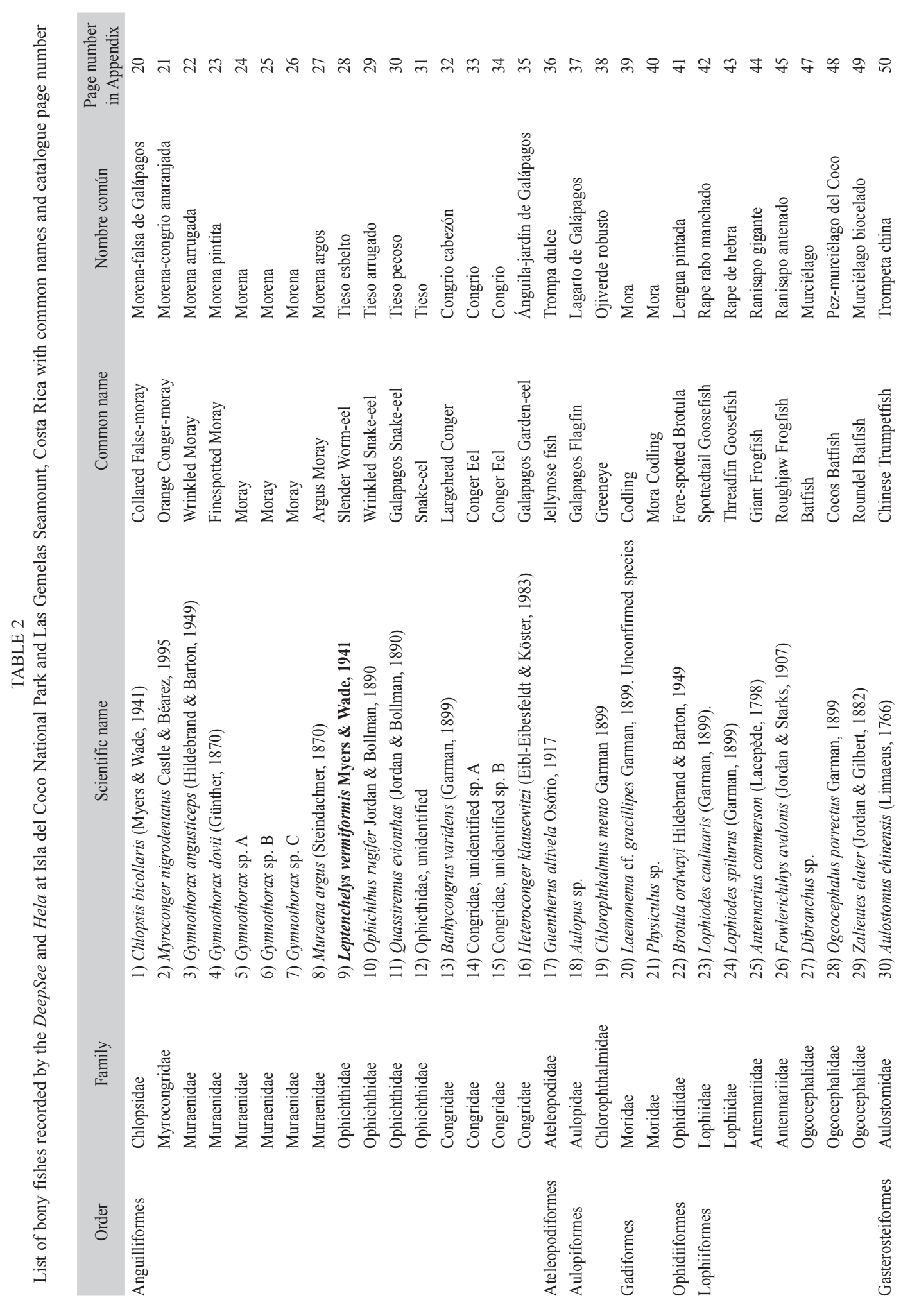




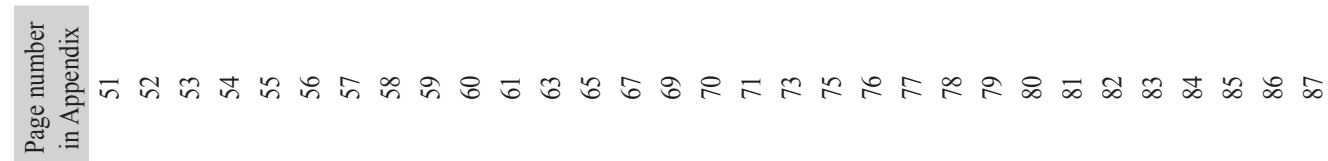

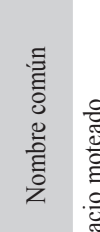

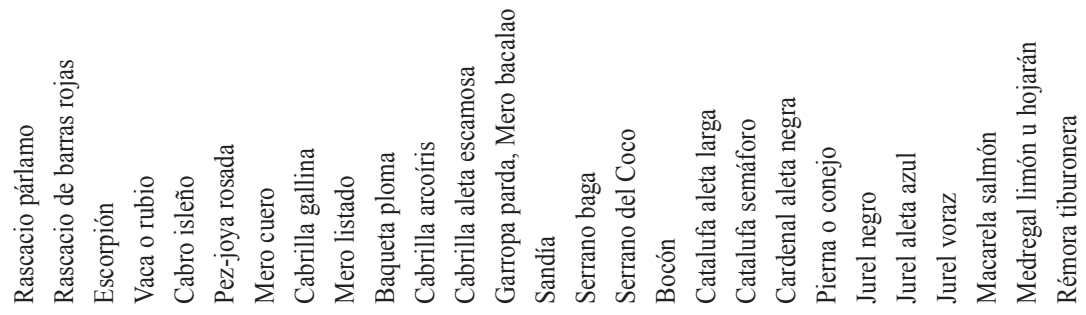

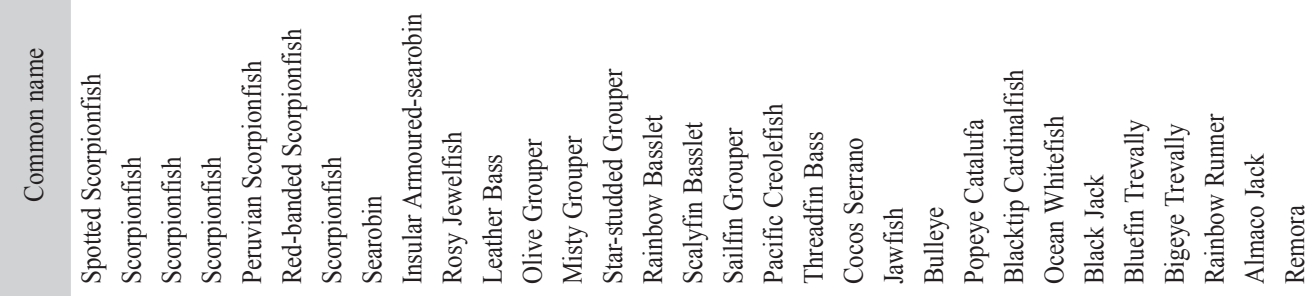

惫

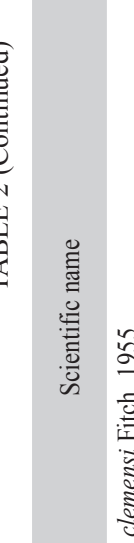

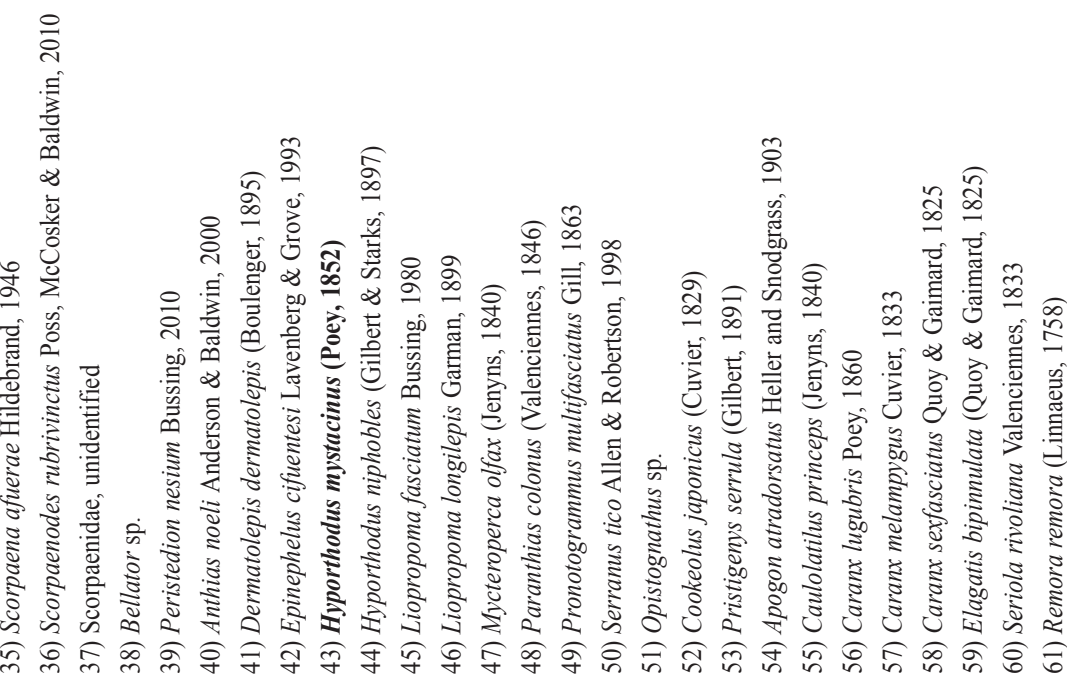

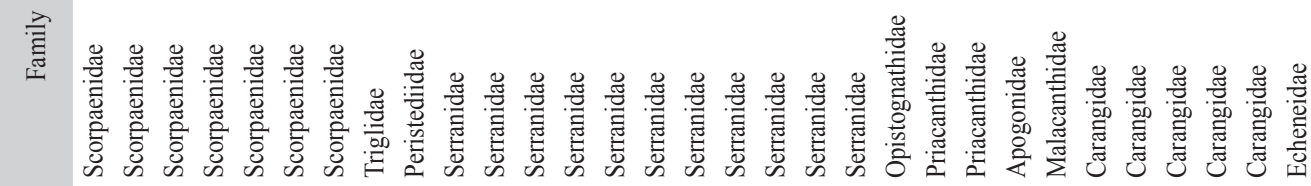

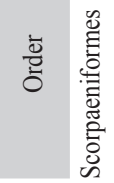
总 


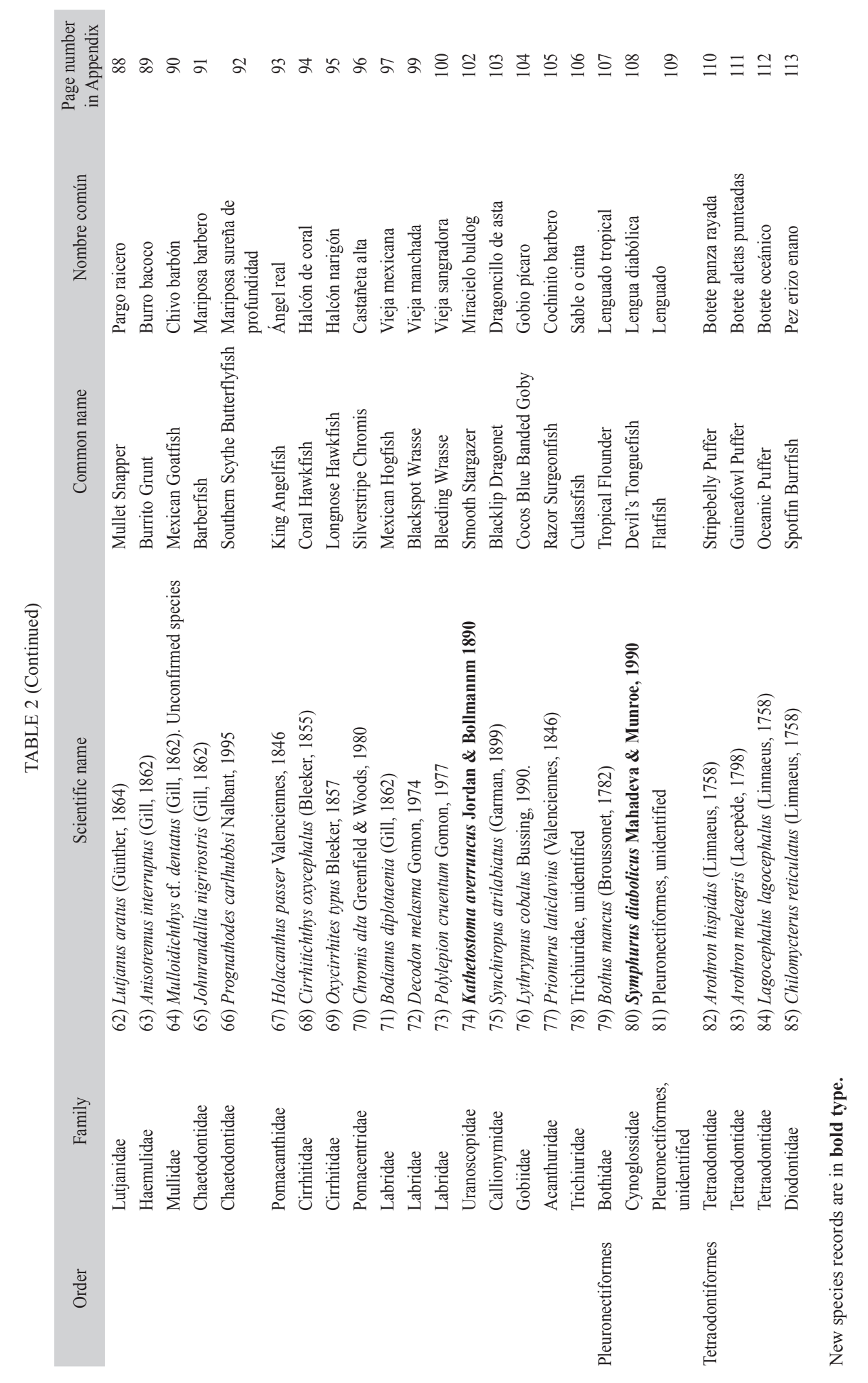


Allen (2015), and FishBase (Froese \& Pauly, 2012). Since all the identifications were visually made, the largest possible number of images from different angles of the fishes was examined and images were compared with published photographs whenever possible. Coloration was one of the most important features; however, some of the images allowed useful meristic and morphometric measurements, although not precise in all cases. Identifications of the fish taxa, together with relevant images, were sent for corroboration to various experts: Rachel J. Arnold (University of Washington), Ginger Garrison (U.S. Geological Survey), Theodore W. Pietsch (University of Washington), Stuart G. Poss (California Academy of Science), Eva
Salas (Cabrillo College, California), Wayne C. Starnes (North Carolina Museum of Natural History), Richard Starr (Moss Landing Marine Laboratory), Franz Uiblein (Institute of Marine Research, Norway) and Benjamin Victor (Ocean Science Foundation).

In a few cases, we present some low-quality images because there were no photographs with better resolution, although it was still possible to identify the species. Finally, how often the submersible DeepSee and ROV Hela have acquired videos of bony fishes at Isla del Coco National Park and Las Gemelas Seamount, as well the percentage of dives and sites where each species was observed, are presented in Table 3. To evaluate how representative our

TABLE 3

Frequency (number and percentage of dives) in which the submersible DeepSee and ROV Hela has acquired videos of bony fishes at Isla del Coco National Park and Las Gemelas Seamount, with depth ranges and specific location for each species

\begin{tabular}{|c|c|c|c|c|}
\hline Taxa & Dives (\#) & Dives $(\%)$ & Depth (m) & Location \\
\hline Anisotremus interruptus* & 8 & 2.1 & $20-90$ & 12,13 \\
\hline Antennarius commerson* & 2 & 0.5 & $20-87$ & 12,13 \\
\hline Anthias noeli ${ }^{\dagger}$ & 33 & 8.8 & $90-350$ & $1,4,5,8,12,18$ \\
\hline Apogon atradorsatus & 1 & 0.3 & $40-50$ & 13 \\
\hline Arothron hispidus & 2 & 0.5 & $10-80$ & 12 \\
\hline Arothron meleagris* & 5 & 1.3 & $10-80$ & 12,13 \\
\hline Aulopus sp..$^{\dagger}$ & 10 & 2.7 & $150-310$ & $3,4,5,6$ \\
\hline Aulostomus chinensis & 7 & 1.9 & $45-60$ & 12,13 \\
\hline Bathycongrus varidens & 9 & 2.4 & $215-304$ & $5,8,18$ \\
\hline Bellator sp. & 1 & 0.3 & 110 & 14 \\
\hline Bodianus diplotaenia* & 29 & 7.7 & $40-85$ & 12,15 \\
\hline Bothus mancus & 1 & 0.3 & $40-60$ & 13 \\
\hline Brotula ordwayi & 35 & 9.3 & $83-200$ & $1,4,6,8,12$ \\
\hline Caranx lugubris & 11 & 2.9 & $0-86$ & 12 \\
\hline Caranx melampygus & 1 & 0.3 & $0-86$ & 12 \\
\hline Caranx sexfasciatus & 4 & 1.1 & $0-50$ & 12 \\
\hline Caulolatilus princeps* & 7 & 1.9 & $50-160$ & 6,12 \\
\hline Chilomycterus reticulatus & 4 & 1.1 & $45-60$ & 12 \\
\hline Chlopsis bicollaris* & 2 & 0.5 & $45-90$ & 12 \\
\hline Chlorophthalmus mento & 5 & 1.3 & $250-311$ & 11,16 \\
\hline Chromis alta & 3 & 0.8 & $80-90$ & 12 \\
\hline Cirrhitichthys oxycephalus* & 2 & 0.5 & $40-65$ & 12,13 \\
\hline Congridae, unidentified sp. A & 1 & 0.3 & 250 & 16 \\
\hline Congridae, unidentified sp. B & 1 & 0.3 & $250-400$ & 5 \\
\hline Cookeolus japonicus & 58 & 15.4 & $45-300$ & $12,13,15$ \\
\hline Decodon melasma* & 4 & 1.1 & $150-300$ & $1,3,5,6$ \\
\hline Dermatolepis dermatolepis* & 48 & 12.8 & $45-90$ & $12,13,15$ \\
\hline
\end{tabular}


TABLE 3 (Continued)

\begin{tabular}{|c|c|c|c|c|}
\hline Taxa & Dives (\#) & Dives $(\%)$ & Depth (m) & Location \\
\hline Dibranchus sp. & 1 & 0.3 & $30-150$ & 16 \\
\hline Elagatis bipinnulata & 5 & 1.3 & $0-86$ & 12 \\
\hline Epinephelus cifuentesi* & 57 & 15.2 & $45-250$ & $2,3,4,5,6,8,12,14,15$ \\
\hline Fowlerichthys avalonis & 111 & 29.5 & $150-220$ & $3,4,6$ \\
\hline Guentherus altivela & 87 & 23.1 & $200-402$ & $5,8,18$ \\
\hline Gymnothorax angusticeps & 41 & 10.9 & $80-180$ & $4,6,8,12,18$ \\
\hline Gymnothorax dovii* & 9 & 2.4 & $45-160$ & 6,12 \\
\hline Gymnothorax sp. A & 2 & 0.5 & $180-230$ & 3,8 \\
\hline Gymnothorax sp. B & 3 & 0.8 & $130-170$ & 6,7 \\
\hline Gymnothorax sp. C & 4 & 1.1 & $150-170$ & 6 \\
\hline Heteroconger klausewitzi* & 3 & 0.8 & $50-90$ & 12,13 \\
\hline Holacanthus passer & 9 & 2.4 & $20-60$ & 12 \\
\hline Hyporthodus mystacinus & 55 & 14.6 & $62-330$ & $3,4,5,9,12,13,15,18$ \\
\hline Hyporthodus niphobles & 47 & 12.5 & $80-450$ & $1,2,3,4,5,6,8,12,18$ \\
\hline Johnrandallia nigrirostris* & 2 & 0.5 & $10-50$ & 12,13 \\
\hline Kathetostoma averruncus & 2 & 0.5 & $180-311$ & 4,11 \\
\hline Laemonema cf. gracillipes ${ }^{\dagger}$ ? & 4 & 1.1 & $150-250$ & $3,5,6,11$ \\
\hline Lagocephalus lagocephalus & 3 & 0.8 & $0-200$ & 5,12 \\
\hline Leptenchelys vermiformis* & 4 & 1.1 & $223-400$ & 5,18 \\
\hline Liopropoma fasciatum & 3 & 0.8 & $60-160$ & 6,12 \\
\hline Liopropoma longilepis* & 10 & 2.7 & $130-450$ & $1,3,5,6,11$ \\
\hline Lophiodes caulinaris & 2 & 0.5 & $70-300$ & 5,12 \\
\hline Lophiodes spilurus & 5 & 1.3 & $130-300$ & 3,5 \\
\hline Lutjanus aratus* & 10 & 2.7 & $0-80$ & 12,13 \\
\hline Lythrypnus cobalus & 8 & 2.1 & $60-90$ & 12 \\
\hline Mulloidichthys cf. dentatus & 1 & 0.3 & $0-60$ & 12 \\
\hline Muraena argus & 23 & 6.1 & $60-90$ & 12,13 \\
\hline Mycteroperca olfax & 33 & 8.8 & $50-90$ & $4,12,13,15$ \\
\hline Myroconger nigrodentatus & 25 & 6.6 & $150-220$ & $3,4,6,7$ \\
\hline Ogcocephalus porrectus & 6 & 1.6 & $30-150$ & 12,13 \\
\hline Ophichthidae, unidentified & 3 & 0.8 & $150-250$ & $3,6,16,17$ \\
\hline Ophichthus rugifer & 3 & 0.8 & $110-180$ & 6,14 \\
\hline Opistognathus sp. & 1 & 0.3 & $45-80$ & 12 \\
\hline Oxycirrhites typus & 1 & 0.3 & 84 & 12 \\
\hline Paranthias colonus & 27 & 7.2 & $45-90$ & $4,12,15$ \\
\hline Peristedion nesium* & 3 & 0.8 & $130-200$ & 4,6 \\
\hline Physiculus sp. & 14 & 3.7 & $200-304$ & $3,5,16,18$ \\
\hline Pleuronectiformes, unidentified & 1 & 0.3 & $180-190$ & 4 \\
\hline Polylepion cruentum ${ }^{\dagger *}$ & 9 & 2.4 & $80-305$ & $5,6,8,12,16,18$ \\
\hline Pontinus clemensi & 50 & 13.3 & $150-230$ & $1,2,3,4,5,6,7,9$ \\
\hline Pontinus sp. A & 10 & 2.7 & $220-320$ & 5 \\
\hline Pontinus sp. B & 7 & 1.9 & $180-400$ & $4,5,16,18$ \\
\hline Pontinus sp. C & 9 & 2.4 & $150-220$ & $1,3,4,5,6,7,17$ \\
\hline Prionurus laticlavius* & 1 & 0.3 & $40-65$ & 13 \\
\hline Pristigenys serrula & 3 & 0.8 & $60-90$ & 15 \\
\hline Prognathodes carlhubbsi & 4 & 1.1 & $90-150$ & 12,15 \\
\hline Pronotogrammus multifasciatus & 35 & 9.3 & $80-226$ & $1,2,3,4,6,9,18$ \\
\hline
\end{tabular}


TABLE 3 (Continued)

\begin{tabular}{lcccc}
\multicolumn{1}{c}{ Taxa } & Dives $(\#)$ & Dives $(\%)$ & Depth $(\mathrm{m})$ & Location \\
Quassiremus evionthas* & 2 & 0.5 & $40-80$ & 12,13 \\
Remora remora* & 2 & 0.5 & $40-300$ & 6,12 \\
Scorpaena afuerae & 26 & 6.9 & $60-90$ & 12,13 \\
Scorpaenidae, unidentified & 1 & 0.3 & $150-170$ & 6 \\
Scorpaenodes rubrivinctus & 9 & 2.4 & $150-230$ & $4,5,6,18$ \\
Seriola rivoliana & 13 & 3.5 & $20-90$ & 12 \\
Serranus tico* & 10 & 2.7 & $10-60$ & 5,10 \\
Symphurus diabolicus & 4 & 1.1 & $250-316$ & 6 \\
Synchiropus atrilabiatus & 1 & 0.3 & 155 & 5 \\
Trichiuridae, unidentified & 1 & 0.3 & 300 & $3,4,12$ \\
Zalieutes elater & 7 & 1.9 & $80-200$ & \\
\hline
\end{tabular}

Locations (Fig. 3): 1) Argo 2, 2) Kili Rock, 3) The Edge, 4) Kili 2, 5) The Wall 475, 6) Piedra 165, 7) Kili, 8) Piedra Drop, 9) Banana, 10) Canyons, 11) Boulders, 12) Everest, 13) Bajo Manuelita, 14) Arena, 15) The Arch, 16) Las Gemelas 1, 17) Las Gemelas 2, 18) Las Gemelas 3. New species records are in bold type and the ones marked with a symbol are those whose depth ranges have expanded (*maximum depth increasead, ${ }^{\dagger}$ minimum depth decreased).

sampling was to elucidate fish biodiversity, a cumulative species curve was ploted with the function 'specaccum' of the package 'vegan' (Oksanen et al., 2018), using R (R Core Team, 2018). Random method was used, which finds the mean species accumulation curve and its standard deviation from random permutations of the data (999 in this case) (Gotelli \& Colwell, 2001). The species richness estimator Chao was calculated using the function 'chao2' of 'fossil' package (Vavrek, 2011), designed for an incidence matrix.

\section{RESULTS AND DISCUSSION}

Images of bony fishes were obtained from 376 dives made to depths between 50 and $450 \mathrm{~m}$, during which a total of 85 taxa were observed, corresponding to 66 genera, 42 families and 11 orders (Table 2, Appendix). The richest orders were Perciformes (20 families, 39 species), Anguilliformes (six families, 16 species), Scorpaeniformes (three families, nine species) and Lophiiformes (three families, seven species). Serranidae was the richest family with 11 species. Four new records are reported for Isla del Coco: Leptenchelys vermiformis (Ophichthidae), Hyporthodus mystacinus (Serranidae), Kathetostoma averruncus
(Uranoscopidae), and Symphurus diabolicus (Cynoglossidae) (Table 2). Depth ranges of twenty-six species are expanded beyond previously published records (Table 3, Table 4). The minimum known depth was decreased for three species, ranging between 10 and 365 $\mathrm{m}$ shallower than that previously reported in the literature; the maximum known depth was increased for 22 species, ranging between 7 and $315 \mathrm{~m}$; also, one species was observed both shallower and deeper than previous records (Table 3, Table 4), suggesting that our knowledge on the vertical distribution of many species is limited.

The species most frequently observed were Fowlerichthys avalonis (Antennariidae), Guentherus altivela (Ateleopodidae), Cookeolus japonicus (Priacanthidae), Epinephelus cifuentesi (Serranidae), H. mystacinus (Serranidae) and Pontinus clemensi (Scorpaenidae) (Table 3). These species might have important ecological roles that should be assessed in future research. As zooplanktivorous in the case of $C$. japonicus, that was observed forming big groups, or as predators in all the other cases, these common species must sustain significative links in the local food chain.

Meanwhile, some species were observed only once, including unidentified species of 
TABLE 4

List of bony fishes with details on changes of depth distribution at Isla del Coco National Park and Las Gemelas Seamount, Costa Rica

\begin{tabular}{|c|c|c|c|c|c|c|}
\hline \multirow{2}{*}{ SPECIES } & \multicolumn{3}{|c|}{ Maximum Depth (m) } & \multicolumn{3}{|c|}{ Minimum Depth (m) } \\
\hline & Previous record & New record & Net change & Previous record & New record & Net change \\
\hline Anisotremus interruptus & 30 & 90 & 60 & & & \\
\hline Antennarius commerson & 70 & 87 & 17 & & & \\
\hline Anthias noeli & & & & 100 & 90 & 10 \\
\hline Arothron meleagris & 73 & 80 & 7 & & & \\
\hline Aulopus sp. & & & & 305 & 150 & 155 \\
\hline Bodianus diplotaenia & 76 & 85 & 9 & & & \\
\hline Caulolatilus princeps & 150 & 160 & 10 & & & \\
\hline Chlopsis bicollaris & 30 & 90 & 60 & & & \\
\hline Cirrhitichthys oxycephalus & 40 & 65 & 25 & & & \\
\hline Decodon melasma & 300 & 220 & 80 & & & \\
\hline Dermatolepis dermatolepis & 40 & 90 & 50 & & & \\
\hline Epinephelus cifuentesi & 135 & 250 & 115 & & & \\
\hline Gymnothorax dovii & 70 & 160 & 90 & & & \\
\hline Heteroconger klausewitzii & 30 & 90 & 60 & & & \\
\hline Johnrandallia nigrirostris & 40 & 50 & 10 & & & \\
\hline Laemonema cf. gracillipes & & & & 515 & 150 & 365 \\
\hline Leptenchelys vermiformis & 85 & 400 & 315 & & & \\
\hline Liopropoma longilepis & 250 & 450 & 200 & & & \\
\hline Lutjanus aratus & 60 & 80 & 20 & & & \\
\hline Mycteroperca olfax & 100 & 180 & 80 & & & \\
\hline Peristedion nessium & 180 & 200 & 20 & & & \\
\hline Polylepion cruentum & 200 & 305 & 105 & 150 & 80 & 70 \\
\hline Prionurus laticlavius & 30 & 65 & 35 & & & \\
\hline Quassiremus evionthas & 30 & 80 & 50 & & & \\
\hline Remora remora & 200 & 300 & 100 & & & \\
\hline Serranus tico & 43 & 60 & 17 & & & \\
\hline
\end{tabular}

Congridae, Scorpaenidae, Trichiuridae and Pleuronectiformes (Table 3). Other uncommon fishes were unidentied species of Bellator (Triglidae), Dibranchus (Ogcocephalidae) and Opistognathus (Opistognathidae). Some of the uncommon species may have been underestimated due to their small size (as Apogon atradorsatus, Oxycirrhites typus and Synchiropus atrilabiatus), or they may be unusual in deep waters (as Prionurus laticlavius, a common species in shallow waters).

For some fishes, only higher taxonomic identification was possible at level of genus (11), family (5) or order (1). In two cases, species is proposed but unconfirmed, so the information is presented in terms of a higher taxonomic level (Laemonema cf. gracillipes and Mulloidichthys cf. dentatus). The latter species is suggested because two very similar species of Mulloidichthys are known to cooccur in the TEP (Robertson \& Allen, 2015), which makes it difficult to distinguish between them based on the photographs. Images of Aulopus sp. were identified to genus, although earlier works at Isla del Coco reported this species as Aulopus bajacali. However, is now recognized that the species present around Isla del Coco and Galápagos is a distinct species from A. bajacali, therefore Aulopus sp. present at Isla del Coco has already a holotype and paratypes but its description was never published (see the catalogue for more information). In 
other cases, the identification was not possible at the species level because better images and/ or specimen collection are required, and some of them might be new species.

Despite more systematic studies are needed at Isla del Coco to establish the specific fish fauna depth boundaries between the altiphotic, mesophotic and rariphotic zones, using the same depth ranges found in the Caribbean by Baldwin et al. (2018) a strong shift on the species composition was observed in this study, mainly between the mesophotic and rariphotic zone (approximately at $130 \mathrm{~m}$ ). According to the known depth range for each species most of fishes associated with deep areas at Isla del Coco can be found both in the altiphotic and the mesophotic zone (37.6\% of the species), followed by species restricted to deeper areas at the rariphotic zone or below $(31.8 \%)$. The mesophotic and rariphotic zone shared a total of 15 species (17.6\%), while $7.1 \%$ were restricted to the mesophotic zone, and only 5 species $(5.9 \%)$ had a wider vertical distribution from the altiphotic to the rariphotic zone. As Baldwin et al. (2018) stated, the mesophotic zone can act as refugia for shallow-water species stressed by global warming, and so may the rariphotic zone for mesophotic species. This highlights the importance of the biological studies in deep zones, which should be consider as prioritary research in order to understand the impacts of global change in our oceans.

Once the depth boundaries at which changes in species composition occur, the specific ecological role of each species in each zone should be assessed. Auster et al. (2016) established a foundation on the strength of behavioral interactions within and between deepwater fish species at Isla del Coco and Las Gemelas Seamount, and recognized that information on feeding, growth and fecundity are important features to a better understanding of the region. Of the total species we found, 67 were predators $(78.8 \%)$, while 15 were strictly or not zooplanktivorous (17.6 $\%), 2$ species were omnivorous, and just 1 species was herbivorous. Half of the zooplantivorous species include other elements in their diets, as predators (Cirrhitichthys oxycephalus,
Elagatis bipinnulata, Lagocephalus lagocephalus, Lythrypnus cobalus and O. typus) or as predators and cleaners eating ectoparasites (as Johnrandallia nigrirostris, Holacanthus passer, Remora remora); the other half are strictly zooplaktivorous, as the congrid Heteroconger klausewitzi, the serranids Anthias noeli, Paranthias colonus and Pronotogrammus multifasciatus, the priacanthid $C$. japonicus, the apogonid A. atradorsatus and the pomacentrid Chromis alta. The omnivorous fishes were represented by the genus Arothron (Tetraodontidae) and were only seen at the shallower locations (Bajo Manuelita and Everest). Bajo Manuelita was also the location where the only herbivorous, $P$. laticlavius, was seen, which is related to the amount of light reaching this area that allows algae development.

These results provide useful management information for the area in order to ascertain the diversity and distribution of taxa subject to stewardship. Starr et al. (2012b) observed more than 45 taxa of deep-water bony fishes at Isla del Coco National Park and Las Gemelas Seamount from 22 submersible dives. Our study includes information from 376 dives in 18 different locations, which resulted in a total of 85 taxa. As more submersible dives were reviewed the number of species recorded increased (Fig. 4). However, according to the species accumulative curve and the species richness estimator Chao, which suggests a total of 129 fish species, the diversity of fishes between 50 and $450 \mathrm{~m}$ is greater than the described in this study. Furthermore, the depth range expansion found for some species indicates that our knowledge of many deep-water organisms is limited. These statements highlight the importance of continuing systematic deep-water research at Isla del Coco, both for scientific purposes as well as for conservation. The species list with updated known depth ranges presented here, as well as the new reports and unidentified species that might be new species, serve as a framework for the conservation of Isla del Coco's deepwater environments and should motivate future research in this biodiversity hotspot. 


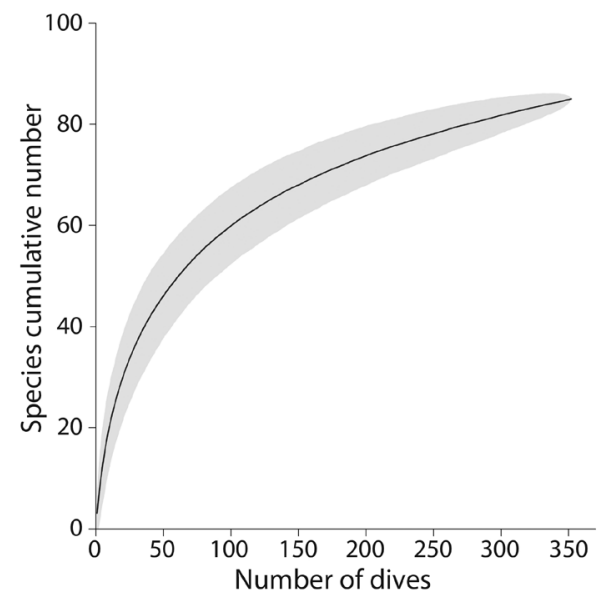

Fig. 4. Species accumulative curve of fishes recorded by the submersible DeepSee and ROV Hela in deep waters $(50-450 \mathrm{~m})$ at Isla del Coco National Park and Las Gemelas Seamount (2006-2015).

\section{ACKNOWLEDGEMENTS}

We thank the Undersea Hunter Group for the use of the videos from DeepSee and University of Connecticut for ROV Hela operations, ACMIC and Isla del Coco National Park for the permits to develop this project; Vicerrectoría de Investigación and Centro de Investigación en Ciencias del Mar (CIMAR), Universidad de Costa Rica, for their financial and logistic Support; and the Consejo Nacional de Rectores de las Universidades Públicas (CONARE) for its financial support. The 2012 expedition to Las Gemelas Seamount was supported mainly by the National Geographic Society and the U.S. National Science Foundation. We appreciate the time taken by the following ichthyologists that helped us with the identification and/or the review of drafts of this paper: Rachel J. Arnold, Ginger Garrison, Ted Pietsch, Stuart Poss, Eva Salas, Wayne Starnes, Rick Starr, Franz Uiblein and Benjamin Victor. We thank Catalina Benavides, SIGMARCIMAR, Universidad de Costa Rica for Figure 3. Also, we are grateful to seven anonymous reviewers, who with their comments helped to improve the manuscript. This work was printed thanks to the financial support of MarViva and Undersea Hunter Group.

\section{RESUMEN}

Catálogo actualizado de peces óseos observados en aguas profundas en el Parque Nacional Isla del Coco y en el monte submarino Las Gemelas. Aunque la biodiversidad marina de la Isla del Coco, Costa Rica, ha sido relativamente bien estudiada y documentada, todavía hay regiones poco exploradas con gran potencial para la investigación, como es el caso de las zonas profundas. Desde 2006 el sumergible DeepSee, se ha utilizado para estudiar las aguas profundas en el Parque Nacional Isla del Coco. En este trabajo se presenta un catálogo de peces óseos filmados desde el sumergible entre 50 y $450 \mathrm{~m}$ de profundidad de la Isla del Coco, a $500 \mathrm{~km}$ sur-suroeste de la costa de Costa Rica, y en los Montes Submarinos Las Gemelas, a $50 \mathrm{~km}$ al suroeste de la Isla del Coco. Los vídeos fueron tomados con una cámara digital de alta definición colocada sobre el sumergible, y a partir de estos vídeos en el laboratorio fue creada una base de datos con fotos de peces óseos, utilizando la información recopilada durante el periodo 2006-2015. Se obtuvo información adicional de la distibución de los peces utilizando el submarino no tripulado Hela, durante 11 buceos (24,3 hrs) en los Montes Submarinos Las Gemelas en febrero 2012. Las tomas de peces óseos se obtuvieron de 376 inmersiones (365 con el DeepSee y 11 con el Hela) en 18 localidades diferentes y se presenta aquí un total de 85 taxones (consideradas especies distintas). En el catálogo se muestran imágenes que representan las primeras fotografías a color para algunas especies. Algunos organismos solo se pudieron identificar a nivel de género (11), familia (5) u orden (1). Se reporta por primera vez la presencia de cuatro especies: Hyporthodus mystacinus (Serranidae), Kathetostoma averruncus (Uranoscopidae), Leptenchelys vermiformis (Ophichthidae) y Symphurus diabolicus (Cynoglossidae). Ampliamos la profundidad máxima conocida para veintiseis especies; tres fueron observadas en aguas más someras, veintidós en aguas más profundas y una se extiende a aguas más someras y más profundas que informes previos. Funcionando como línea base, estos resultados proporcionan información útil para el manejo de la zona, sobre todo si se tiene en cuenta la constante presión de la pesca ilegal en el Parque Nacional y aguas adyacentes. Al igual que otros autores han señalado, encontramos que el mayor esfuerzo de investigación con el sumergible ha contribuido a incrementar la lista de las especies conocidas. Este aspecto pone en evidencia la importancia de mantener una investigación sistemática en aguas profundas del Parque Nacional Isla del Coco y áreas adyacentes, tanto para fines científicos como de conservación.

Palabras Clave: Peces de profundidad; biodiversidad marina; DeepSee; ROV; investigación con sumergible. 


\section{REFERENCES}

Aburto-Oropeza, O., \& Balart-Páez, E. F. (2001). Community structure of reef fish in several habitats of a rocky reef in the Gulf of California. Marine Ecology, 22(4), 283-305.

Aburto-Oropeza, O., Caso, M., Erisman, B., \& Ezcurra, E. (2010). Bitácora del mar profundo: una expedición por el Golfo de California. México, D. F. and La Joya, California: Instituto Nacional de Ecología, UCMEXUS, Scripps Institution of Oceanography.

Allen, G. R. (1995). Lutjanidae. In W. Fischer, F. Krupp, W. Schneider, C. Sommer, K. E. Carpenter, \& V. H. Niem (Eds.), Guía FAO para la identificación de especies para los fines de la pesca. Pacífico CentroOriental. Vol. III (pp. 1231-1244). Rome, Italy: FAO.

Anderson, W. D., \& Baldwin, C. C. (2000). A new species of Anthias (Teleostei: Serranidae: Anthiinae) from the Galápagos Islands, with keys to Anthias and eastern Pacific Anthiinae. Proceedings-Biological Society of Washington, 113(2), 369-385.

Angulo, A., Naranjo-Elizondo, B., Corrales-Ugalde, M., \& Cortés, J. (2014). First record of the genus Paracaristius (Perciformes: Caristiidae) from the Pacific of Central America, with comments on their association with the siphonophore Praya reticulata (Siphonophorae: Prayidae). Marine Biodiversity Records, 7, e132.

Angulo-Sibaja, A. (2014). Deep water fishes of the Pacific of Costa Rica: diversity, distribution and biogeographic relationships (master's thesis). Programa de Posgrado en Biología, Universidad de Costa Rica, San Pedro, Costa Rica.

Auster, P., Sánchez-Jiménez, A., Rodríguez-Arrieta, A., Quesada, A., Pérez, C., Naranjo-Elizondo, B., ... Cortés, J. (2016). Facilitative behavioral interactions between deepwater piscivores at Isla del Coco National Park and Las Gemelas Seamount, Costa Rica. Revista de Biología Tropical, 64(Supplement 1), S187-S196.

Baldwin, C. C., \& McCosker, J. E. (2001). Wrasses of the Galápagos Islands, with the description of a new deepwater species of Halichoeres (Perciformes: Labridae). Revista de Biologia Tropical, 49(Supplement 1), 89-100.

Baldwin, C. C., Tornabene, L., \& Robertson, D. R. (2018) Below the mesophotic. Scientific Reports, 8(1), 4920. DOI: $10.1038 / \mathrm{s} 41598-018-23067-1$

Béarez, P., \& Jiménez-Prado, P. (2003). New records of serranids (Perciformes) from the continental shelf of Ecuador with a key to the species, and comments on ENSO-associated fish dispersal. Cybium, 27(2), 107-115.

Böhlke, E. B., \& Smith, D. G. (2002). Type catalogue of Indo-Pacific Muraenidae. Proceedings of the Academy of Natural Sciences of Philadelphia, 152(1), 89-172.

Bradbury, M. G. (1980). A revision of the fish genus Ogcocephalus with descriptions of new species from the western Atlantic Ocean (Ogcocephalidae: Lophiformes). Proceedings of the California Academy of Sciences, 42(7), 229-285.

Bradbury, M. G. (1999). A review of the fish genus Dibranchus with descriptions of new species and a new genus, Solocisquama (Lophiiformes, Ogcocephalidae). Proceedings of the California Academy of Sciences, 51(5), 259-310.

Breedy, O., Van Ofwegen, L. P., \& Vargas, S. (2012). A new family of soft corals (Anthozoa, Octocorallia, Alcyonacea) from the aphotic Tropical Eastern Pacific waters revealed by integrative taxonomy. Systematics and Biodiversity, 10(3), 351-359.

Bussing, W. A. (1980). Liopropoma fasciatum, a new serranid fish and only known member of the genus from the Tropical Eastern Pacific Ocean (Costa Rica, Panama). Revista de Biología Tropical, 28(1), 147-151.

Bussing, W. A. (1990). New species of gobiid fishes of the genera Lythrypnus, Elacatinus and Chriolepis from the Eastern Tropical Pacific. Revista de Biología Tropical, 38(1), 99-118.

Bussing, W. A. (1995). Tetraodontidae. Tamboriles, tamborines, botetes, peces globo, corrotuchos. In W. Fischer, F. Krupp, W. Schneider, C. Sommer, K. E. Carpenter, \& V. H. Niem (Eds.), Guía FAO para la identificación de especies para los fines de la pesca. Pacífico Centro-Oriental. Vol. III (pp. 1629-1637). Rome, Italy: FAO.

Bussing, W. A. (2010). A new fish, Peristedion nesium (Scorpaeniformes: Peristediidae) from Isla del Coco, Costa Rica. Revista de Biología Tropical, 58(4), 1149-1156.

Bussing, W. A., \& Lavenberg, R. J. (1995a). Cirrhitidae. In W. Fischer, F. Krupp, W. Schneider, C. Sommer, K. E. Carpenter, \& V. H. Niem (Eds.), Guía FAO para Identificación de Especies para los Fines de la Pesca. Pacifico Centro-Oriental. Vol. III (pp. 1007-1010). Rome, Italy: FAO.

Bussing, W. A., \& Lavenberg, R. J. (1995b). Uranoscopidae. In W. Fischer, F. Krupp, W. Schneider, C. Sommer, K. E. Carpenter, \& V. H. Niem (Eds.), Guía FAO para Identificación de Especies para los Fines de la Pesca. Pacífico Centro-Oriental. Vol. III (pp. 1649-1650). Rome, Italy: FAO.

Bussing, W. A., \& López M. I. (1977). Guentherus altivela Osorio, the first ateleopodid fish reported from the Eastern Pacific Ocean (Costa Rica). Revista de Biología Tropical, 25(2), 179-190. 
Bussing, W. A., \& López, M. I. (2005). Peces de la Isla del Coco y peces arrecifales de la costa Pacífica de América Central meridional. Revista de Biología Tropical, 53(Supplement 2), 5-192.

Bussing, W. A., \& López, M. (2009). Marine fish. In I. S. Wehrtmann, \& J. Cortés (Eds.) Marine Biodiversity of Costa Rica, Central America (pp. 453-458). Berlin: Springer.

Caruso, J. H. (1995). Family Lophiidae. In W. Fischer, F. Krupp, W. Schneider, C. Sommer, K. E. Carpenter, \& V. H. Niem (Eds.), Guía FAO para Identificación de Especies para los Fines de la Pesca. Pacífico CentroOriental. Vol. III (pp. 1227-1230). Rome, Italy: FAO.

Castle, P. H. J. (1999). A new species of garden eel from the Eastern Pacific with comments on Heteroconger digueti (Pellegrin) and related nominal species. Bulletin of Marine Science, 64(3), 407-417.

Chirichigno, F. (1978). Nuevas adiciones a la Ictiofauna marina del Perú. (Informe $\mathrm{N}^{\mathrm{o}}$ 46). Callao: Instituto del Mar del Perú-IMARPE.

Corrales-Ugalde, M., Quesada, A. J., Naranjo-Elizondo, B., \& Cortés, J. (2017). New records of gelatinous zooplankton from an oceanic island in the Eastern Tropical Pacific. Journal of the Marine Biological Association of the United Kingdom, 2017, 1-8. DOI: $10.1017 / \mathrm{S} 0025315417000558$

Cortés, J. (2008). Historia de la investigación marina de la Isla del Coco, Costa Rica. Revista de Biología Tropical, 56(Supplement 2), 1-18.

Cortés, J. (2012). Marine biodiversity of an Eastern Tropical Pacific oceanic island, Isla del Coco, Costa Rica. Revista de Biología Tropical, 60(Supplement 3), 131-185.

Cortés, J. (2016). Isla del Coco: Coastal and marine ecosystems. In M. Kappelle (Ed.), Costa Rican Ecosystems (pp. 162-191). Chicago and London: University of Chicago Press.

Cortés, J., \& Blum, S. (2008). Life to $450 \mathrm{~m}$ depth at Isla del Coco, Costa Rica. Revista de Biología Tropical, 56(Supplement 2), 189-206.

Cortés, J., Sánchez-Jiménez, A., Rodríguez-Arrieta, J. A., Quirós-Barrantes, G., González, P. C., \& Blum, S. (2012). Elasmobranchs observed in deepwaters (45-330 m) at Isla del Coco National Park, Costa Rica (Eastern Tropical Pacific). Revista de Biología Tropical, 60(Supplement 3), 257-273.

Erisman, B. E., Konotchick, T. H., \& Blum, S. (2009). Observations of spawning in the leather bass, Dermatolepis dermatolepis (Teleostei: Epinephelidae), at Cocos Island, Costa Rica. Environmental Biology of Fishes, 85(1), 15-20.
Eschmeyer, W. N., Fricke, R., \& van der Laan, R. (2017). Catalog of Fishes: Genera, Species, References. Retrived from http://researcharchive.calacademy. org/research/ichthyology/catalog/fishcatmain.asp

Fischer, W., Krupp, F., Schneider, W., Sommer, C., Carpenter, K. E., \& Niem, V. H. (1995). Guía FAO para la identificación de especies para los fines de la pesca. Pacifico Centro-Oriental. Vol. III. Rome, Italy: FAO.

Fourriére, M., Alvarado, J. J., Bocos, A. A., \& Cortés, J. (2017). Updated checklist and analysis of completeness of the fish fauna of Isla del Coco, Costa Rica. Marine Biodiversity, 47(3), 813-821. DOI: 10.1007/ s12526-016-0501-6

Fourriére, M., Reyes-Bonilla, H., Rodríguez-Zaragoza, F. A., \& Crane, N. (2014). Fishes of Clipperton Atoll, Eastern Pacific: Checklist, endemism, and analysis of completeness of the inventory. Pacific Science, 68(3), 375-395.

Franke, R. \& Acero, A. (1996). Peces óseos comerciales del Parque Gorgona, Pacífico colombiano (Osteichthyes: Muraenesocidae, Hemiramphidae, Belonidae, Scorpaenidae, Triglidae, Malacanthidae, Gerreidae, Sparidae, Kyphosidae, Sphyraenidae e Istiophoridae). Revista de Biología Tropical, 44(2), 763-770.

Friedlander, A. M., Zgliczynski, B. J., Ballesteros, E., Aburto-Oropeza, O, Bolaños, A., \& Sala, E. (2012). The shallow-water fish assemblage of Isla del Coco National Park, Costa Rica: structure and patterns in an isolated, predator-dominated ecosystem. Revista de Biología Tropical, 60(Supplement 3), 321-338.

Fritzsche, R. A. (1995). Aulostomidae. In W. Fischer, F. Krupp, W. Schneider, C. Sommer, K. E. Carpenter, \& V. H. Niem (Eds.), Guía FAO para Identificación de Especies para los Fines de la Pesca. Pacífico CentroOriental. Vol. III (p. 904). Rome, Italy: FAO.

Froese, R., \& Pauly, D. (2012). Fishbase. (Version 08/2012). Retrived from http://www.fishbase.org

Garrison, G. (2005). Peces de la Isla del Coco/Isla del Coco Fishes ( $2^{\text {nd }}$ ed.). Heredia, Costa Rica: Editorial INBio.

Gomon, M. F. (1977). A new genus and Eastern Pacific species of Bodianine labrid fish. Proceedings of the Biological Society of Washington, 89(54), 621-629.

Gomon, M. F. (1995). Labridae. In W. Fischer, F. Krupp, W. Schneider, C. Sommer, K. E. Carpenter, \& V. H. Niem (Eds.), Guía FAO para Identificación de Especies para los Fines de la Pesca. Pacífico CentroOriental. Vol. III (pp. 1201-1225). Rome, Italy: FAO.

Gotelli, N.J., \& Colwell, R.K. (2001). Quantifying biodiversity: procedures and pitfalls in measurement and comparison of species richness. Ecology Letters, 4, 379-391. 
Heemstra, P. C. (1995). Serranidae. In W. Fischer, F. Krupp, W. Schneider, C. Sommer, K. E. Carpenter, \& V. H. Niem (Eds.), Guía FAO para Identificación de Especies para los Fines de la Pesca. Pacífico CentroOriental. Vol. III (pp. 1565-1613). Rome, Italy: FAO.

Heemstra, P. C., \& Randall, J. E. (1993). FAO species catalogue Vol. 16, Groupers of the World (Family Serranidae, Subfamily Epinephelinae): An annotated and illustrated catalogue of the grouper, rockcod, hind, coral grouper, and lyretail species known to date. FAO Fisheries Synopsis, 125(16).

Hinderstein, L. M., Marr, J. C. A., Martinez, F. A., Dowgia1lo, M. J., Puglise, K. A., Pyle, R. L., ... Appeldoorn, R. (2010). Theme section on "Mesophotic Coral Ecosystem: Characterization, Ecology, and Management”. Coral Reefs, 29, 247-251.

Hoese, D. F. (1995). Gobiidae. In W. Fischer, F. Krupp, W. Schneider, C. Sommer, K. E. Carpenter, \& V. H. Niem (Eds.), Guía FAO para Identificación de Especies para los Fines de la Pesca. Pacífico CentroOriental. Vol. III (pp. 1129-1135). Rome, Italy: FAO.

Hooker, M. (2009). Nuevos registros de peces costeros tropicales para el Perú. Revista Peruana de Biología, 16(1), 33-41.

Hughes, T. P, Barnes, M. L., Bellwood, D. R., Cinner, J. E., Cumming, G. S., Jackson, J. B. C., ... Scheffer, M. (2017). Coral reefs in the Anthropocene. Nature, $546,82-90$

Humann, P., \& Deloach, N. (1993). Reef Fish Identification. Galápagos. Miami, Florida, United States: New World Publications, Inc.

Jiménez-Prado, P., \& Béarez, P. (2004). Peces marinos del Ecuador continental/Marine fishes of continental Ecuador (Vol. 1). Quito, Ecuador: SIMBIOE/ NAZCA/IFEA.

Jordan, D. S., \& Bollman, C. H. (1890). Scientific results of explorations by the US Fish Commission Steamer Albatross No. IV. Descriptions of new species of fishes collected at the Galapagos Islands and along the coast of the United States of Colombia, 1887-1888. Proceedings of the United States National Museum, 12(770), 149-183.

Jordan, D. S., \& Starks, E. C. (1907). Notes on fishes from the island of Santa Catalina, Southern California. Proceedings of the United States National Museum, 32, 67-77.

Krupp, F., \& Schneider, W. (1995). Pomacanthidae. In W. Fischer, F. Krupp, W. Schneider, C. Sommer, K. E. Carpenter, \& V. H. Niem (Eds.), Guía FAO para Identificación de Especies para los Fines de la Pesca. Pacifico Centro-Oriental. Vol. III (pp. 1388-1391). Rome, Italy: FAO.
Lea, R. N., \& Feeney, R. F. (2016). Status of two species of tailfish, Caulolatilus princeps (Jenyns) and C. hubbsi Dooley, originally described from the Galapagos Islands. Galapagos Research, 68, 10-12.

Lea, R. N., \& Rosenblatt, R. H. (2000). Observations on fishes associated with the 1997-98 El Niño off California. Reports of California Cooperative Oceanic Fisheries Investigations, 41, 117-129.

Leis, J. M. (2007). Diodontidae. Porcupine fishes (Burrfishes). In K. E. Carpenter, \& V. H. Niem (Eds.), FAO Species Identification Guide for Fishery Purposes. The Living Marine Resources of the Western Central Pacific. Vol. 6. Bony Fishes, part 4 (Labridae to Latimeriidae), Estuarine Crocodiles (pp. 3958-3965). Rome, Italy: FAO.

Lessios, H. A., \& Robertson, D. R. (2006). Crossing the impassable: genetic connections in 20 reef fishes across the eastern Pacific barrier. Proceedings of the Royal Society B: Biological Sciences, 273(1598), 2201-2208.

Lessios, H. A., \& Robertson, D. R. (2013). Speciation on a round planet: phylogeography of the goatfish genus Mulloidichthys. Journal of Biogeography, 40(12), 2373-2384.

Lizano, O. G. (2012). Rasgos morfológicos alrededor de la Isla del Coco y de sus montes submarinos vecinos, Pacífico de Costa Rica. Revista de Biología Tropical, 60(Supplement 3), 43-51.

Long, D. J., McCosker, J. E., Blum, S., \& Klapfer, A. (2011). Tropical Eastern Pacific records of the prickly shark, Echinorhinus cookei (Chondrichthyes: Echinorhinidae). Pacific Science, 65(4), 433-440.

López, M. I., \& Bussing, W. A. (1982). Lista provisional de los peces marinos de la Costa Pacífica de Costa Rica (rayas, tiburones): Preliminary list of salt-water fishes of the Pacific coast of Costa Rica (rays, sharks). Revista de Biología Tropical, 30(1), 5-26.

López-Garro, A., Zanella, I., Martínez, F., Golfín-Duarte, G., \& Pérez-Montero, M. (2016). La pesca ilegal en el Parque Nacional Isla del Coco, Costa Rica. Revista Biología Tropical, 64(Supplement 1), 249-261.

McCosker, J. E., \& Humann, P. (1996). New records of Galápagos fishes. Noticias de Galápagos, 56, 18-22.

McCosker, J. E., Merlen, G., Long, D. J., Gilmore, R. G., \& Villon, C. (1997). Deepslope fishes collected during the 1995 eruption of Isla Fernandina, Galápagos. Noticias de Galápagos, 58, 22-26.

McCosker, J. E., \& Rosenblatt, R. H. (1995). Ophichthidae. In W. Fischer, F. Krupp, W. Schneider, C. Sommer, K. E. Carpenter, \& V. H. Niem (Eds.), Guía FAO para Identificación de Especies para los Fines de la Pesca. Pacifico Centro-Oriental. Vol. III (pp. 1326-1341). Rome, Italy: FAO. 
McCosker, J. E., \& Rosenblatt, R. H. (2010). The fishes of the Galápagos Archipelago: an update. Proceedings of the California Academy of Sciences, 61(2), 167.

McCosker, J. E., \& Smith, D. G. (2004). The Argus moray, Muraena Argus, added to the California fauna. Proceedings of the California Academy of Sciences, 55, 246-247.

McKay, R. J., \& Schneider, M. (1995). Haemulidae. In W. Fischer, F. Krupp, W. Schneider, C. Sommer, K. E. Carpenter, \& V. H. Niem (Eds.), Guía FAO para Identificación de Especies para los Fines de la Pesca. Pacífico Centro-Oriental. Vol. II (pp. 1326-1341). Rome, Italy: FAO.

Meléndez, C. R., \& Markle, D. F. (1997). Phylogeny and zoogeography of Laemonema and Guttigadus (Pisces; Gadiformes; Moridae). Bulletin of Marine Science, 61, 593-670.

Montoya, M. (2016). Isla del Coco: Terrestrial ecosystems. In M. Kappelle (Ed.), Costa Rican Ecosystems (pp. 192-244). Chicago and London: University of Chicago Press.

Mora, C., Jiménez, J. M., \& Zapata, F. A. (2000). Pontinus clemensi (Pisces: Scorpaenidae) at Malpelo Island, Colombia: new specimen and geographic range extension. Boletin de Investigaciones Marinas y Costeras-INVEMAR, 29(1), 85-88.

Munroe, T. A., \& McCosker, J. E. (2001). Redescription of Symphurus diabolicus a poorly-known, deep-sea tonguefish (Pleuronectiformes: Cynoglossidae) from the Galapagos Archipelago. Revista de Biología Tropical, 49(Supplement 1), 187-198.

Myers, R.F. (1999). Micronesian Reef Fishes: A Comprehensive Guide to the Coral Reef Fishes of Micronesia ( $3^{\text {rd }}$ ed.). Barrigada, Guam: Coral Graphics.

Nakamura, I. (1995). Trichiuridae. In W. Fischer, F. Krupp, W. Schneider, C. Sommer, K. E. Carpenter, \& V. H. Niem (Eds.), Guía FAO para Identificación de Especies para los Fines de la Pesca. Pacífico CentroOriental. Vol. II (pp. 1638-1642). Rome, Italy: FAO.

Nalbant, T. T. (1995). The genus Prognathodes (Pisces: Chaetodontidae) in Eastern Pacific Ocean (Baja California-Galapagos) with a discussion on the phylogeny of the group. Travaux du Museum d'Histoire Naturelle 'Grigore Antipa, 35, 497-526.

Naranjo-Elizondo, B., \& Cortés, J. (2018). Observations of litter deposited in deep waters of Isla del Coco National Park, Eastern Tropical Pacific. Frontiers in Marine Science, 5, 91. DOI: 10.3389/fmars.2018.00091

Nelson, J. S. (2006). Fishes of the World (4th ed.). New York: John Wiley \& Sons.

Nielsen, J. G., Cohen, D. M., Markle, D. F., \& Robins, C. R. (1999). FAO species catalogue Vol. 18, Ophidiiform fishes of the World (Order Ophidiiformes). An annotated and illustrated catalogue of pearlfishes, cuskeels, brotulas and other ophidiiform fishes known to date. FAO Fisheries Synopsis, 18(125).

Oksanen, J., Guillaume-Blanchet, F, Friendly, M., Kindt, R., Legendre, P., McGlinn, D, ... Helene, W. (2018). Vegan: Community Ecology Package. R package version 2.5-1. Retrieved from https://CRAN.R-project. org/package= $=$ egan

Owen, B., \& Reitz, C. (2012). Description of Haliotis drogini new species (Gastropoda: Vetigastropoda: Haliotidae) from Cocos Island, Costa Rica. Abalone: World-Wide Haliotidae: Addendum, 3, 60-62.

Page, L. M., Espinosa-Pérez, H., Findley, L. T., Gilbert, C. R., Lea, R. N., Mandrak, N. E., ... Nelson, J. S. (2013). Common and Scientific Names of Fishes from the United States, Canada, and Mexico ( $7^{\text {th }}$ ed.). Bethesda, Maryland: American Fisheries Society, Special Publication 34.

Paulin, C. D., \& Habib. G. (1982). Remoras (Pisces: Echeneidae) from New Zealand. New Zealand Journal of Zoology, 9, 31-36.

Poss, S. G. (1995). Scorpaenidae. In W. Fischer, F. Krupp, W. Schneider, C. Sommer, K. E. Carpenter, \& V. H. Niem (Eds.), Guía FAO para Identificación de Especies para los Fines de la Pesca. Pacífico CentroOriental. Vol. III (pp. 1544-1564). Rome, Italy: FAO.

Poss, S. G., McCosker, J. E., \& Baldwin, C. C. (2010). A new species of Scorpaenodes (Pisces: Scorpaenidae) from the Galápagos and Cocos islands with discussions of the limits of Scorpaenodes and Thysanichthys. Proceedings of the California Academy of Sciences, 61(1), 235.

Raju, S. N. (1985). Congrid eels of the Eastern Pacific and key to their leptocephali. (NOAA Technical Report NMFS 22).U.S.: Department of Commerce.

Randall, J. E. (2005). Reef and Shore Fishes of the South Pacific: New Caledonia to Tahiti and the Pitcairn Islands (Vol. 1). Honolulu, Hawaii: University of Hawaii Press.

Randall, J. E., Allen, G. R., \& Steene, R. C. (1990). Fishes of the Great Barrier Reef and Coral Sea. Honolulu, Hawaii: University of Hawaii Press.

Randall, J. E., \& Cea, A. (2011). Shore Fishes of Easter Island. Honolulu, Hawaii: University of Hawaii Press.

R Core Team (2018). R: A language and environment for statistical computing. R Foundation for Statistical Computing. Vienna, Austria. Retrieved from https:// www.R-project.org/

Richards, W. J., \& McCosker, J. E. (1998). A new species of the genus Bellator (Pisces: Triglidae), with comments on the trigloids of the Galápagos Islands. 
Proccedings of the Biological Society of Washington, 111(4), 936-941.

Robertson, D. R. (2008). Global biogeographical data bases on marine fishes: caveat emptor. Diversity and Distributions, 14(6), 891-892.

Robertson, D. R., \& Allen, G. R. (2015). Peces Costeros del Pacifico Oriental Tropical: sistema de Información en línea. Versión 2.0. Instituto Smithsonian de Investigaciones Tropicales, Balboa, República de Panamá. Retrieved from http://biogeodb.stri.edu/ sftep/es/

Robertson, D. R., Grove, J. S., \& McCosker, J. E. (2004). Tropical transpacific shore fishes. Pacific Science, $58,507-565$.

Rocha, L. A., Pinheiro, H. T., Shepherd, B., Papastamatiou, Y. P., Luiz, O. J., Pyle, R. L., \& Bongaerts, P. (2018). Mesophotic coral ecosystems are threatened and ecologically distinct from shallow water reefs. Science, 361, 281-284.

Rojas, W., \& Alvarado, G. E. (2012). Geología y contexto geotectónico de la Isla del Coco y la zona marítima frente al Pacífico central de Costa Rica. Revista de Biología Tropical, 60(Supplement 3), 15-32.

Schneider, M. (1995). Chaetodontidae. In W. Fischer, F. Krupp, W. Schneider, C. Sommer, K. E. Carpenter, \& V. H. Niem (Eds.), Guía FAO para Identificación de Especies para los Fines de la Pesca. Pacifico CentroOriental. Vol. II (pp. 1000-1003). Rome, Italy: FAO.

Schneider, W., \& Krupp, F. (1995). Malacanthidae. In W. Fischer, F. Krupp, W. Schneider, C. Sommer, K. E. Carpenter, \& V. H. Niem (Eds.), Guía FAO para Identificación de Especies para los Fines de la Pesca. Pacífico Centro-Oriental. Vol. III (pp. 1266-1271). Rome, Italy: FAO.

Schneider, M., \& Lavenberg, R. J. (1995). Antennariidae. In W. Fischer, F. Krupp, W. Schneider, C. Sommer, K. E. Carpenter, \& V. H. Niem (Eds.), Guía FAO para Identificación de Especies para los Fines de la Pesca. Pacífico Centro-Oriental. Vol. II (pp. 854857). Rome, Italy: FAO.

Smith, D. G. (1994). Catalog of type specimens of recent fishes in the National Museum of Natural History, Smithsonian Institution, 6: Anguilliformes, Saccopharyngiformes, and Notacanthiformes. Smithsonian Contributions to Zoology, 566, 1-50.

Smith, D. G. (1995). Congridae. In W. Fischer, F. Krupp, W. Schneider, C. Sommer, K. E. Carpenter, \& V. H. Niem (Eds.), Guía FAO para Identificación de Especies para los Fines de la Pesca. Pacífico CentroOriental. Vol. II (pp. 1026-1035). Rome, Italy: FAO.
Smith-Vaniz, W. F. (1995). Carangidae. In W. Fischer, F. Krupp, W. Schneider, C. Sommer, K. E. Carpenter, \& V. H. Niem (Eds.), Guía FAO para Identificación de Especies para los Fines de la Pesca. Pacífico CentroOriental. Vol. II (pp. 940-986). Rome, Italy: FAO.

Sommer, C., \& Parin, N. V. (1995). Aulopidae. In W. Fischer, F. Krupp, W. Schneider, C. Sommer, K. E. Carpenter, \& V. H. Niem (Eds.), Guía FAO para Identificación de Especies para los Fines de la Pesca. Pacífico Centro-Oriental. Vol. II (pp. 902903). Rome, Italy: FAO.

Soto, M. (2014). Octubre presenta mayor pesca ilegal en la Isla del Coco. Versión digital. Periódico La Nación, 20 October 2014. Retrived from http://www. nacion.com/vivir/ambiente/Octubre-pesca-ilegal-Isla Coco_0 1446255387.html

Starnes, W. C. (1995). Priacanthidae. In W. Fischer, F. Krupp, W. Schneider, C. Sommer, K. E. Carpenter, \& V. H. Niem (Eds.), Guía FAO para Identificación de Especies para los Fines de la Pesca. Pacífico CentroOriental. Vol. III (pp. 1405-1408). Rome, Italy: FAO.

Starr, R. M., Cortés, J., Barnes, C. L., Green, K., \& Breedy, O. (2012a). Characterization of deepwater invertebrates at Isla del Coco National Park and Las Gemelas Seamount, Costa Rica. Revista de Biología Tropical, 60(Supplement 3), 303-319.

Starr, R. M., Green, K., \& Sala, E. (2012b). Deepwater fish assemblages at Isla del Coco National Park and Las Gemelas Seamount, Costa Rica. Revista de Biologia Tropical, 60(Supplement 3), 347-362.

Sulak, K. J. (1995). Chlorophthalmidae. In W. Fischer, F. Krupp, W. Schneider, C. Sommer, K. E. Carpenter, \& V. H. Niem (Eds.), Guía FAO para Identificación de Especies para los Fines de la Pesca. Pacífico CentroOriental. Vol. II (pp. 1005-1006). Rome, Italy: FAO.

Thompson, B. A. (1998). Redescription of Aulopus bajacali Parin \& Kotlyar, 1984, comments on its relationships and new distribution records. Ichthyological Research, 45(1), 43-51.

Vavrek, M. J. (2011). Fossil: palaeoecological and palaeogeographical analysis tools. Palaeontologia Electronica, 14, 1T. Retrieved from http://palaeo-electronica. org/2011 1/238/index.html

Wehrtmann, I. S., Cortés, J., \& Echeverría-Sáenz, S. (2009). Marine biodiversity of Costa Rica: perspectives and conclusions. In I. S. Wehrtmann, \& J. Cortés (Eds.), Marine Biodiversity of Costa Rica, Central America (pp. 521-533). Berlin: Springer. 


\section{APPENDIX}

Updated catalogue of bony fishes observed in deep waters at Isla del Coco National Park and Las Gemelas Seamount, Costa Rica (Eastern Tropical Pacific)

\section{ORDER ANGUILLIFORMES \\ Family Chlopsidae}

Chlopsis bicollaris (Myers \& Wade, 1941)

Collared False-moray / Morena-falsa de Galápagos

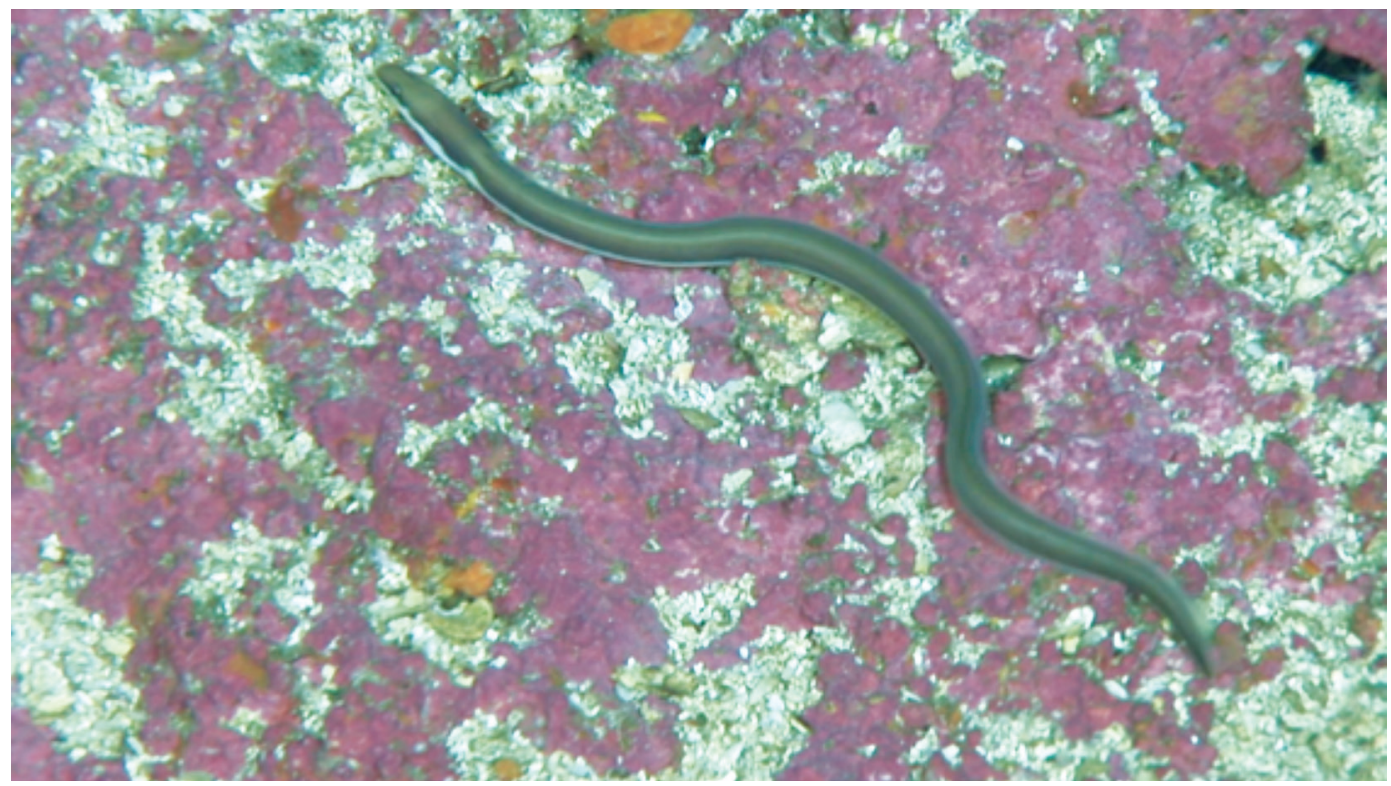

Chlopsis bicollaris at Everest (88 m), 30 November 2010, afternoon.

Description: Body elongate, worm-like in appearance; large eyes, snout conical with rounded tip (Robertson \& Allen, 2015). Contrasting colors, grey-brown above and whitish below; two collarlike whitish bars, one across the head behind the mouth and one at level of gill opening and dorsal fin origin. Without pectoral fins, dorsal and anal fins confluent; gill opening small, oval and lateral. Size: Up to $20 \mathrm{~cm}$. Depth range: 5-30 m (Robertson \& Allen, 2015).

WorLdWIDE DISTRIBUTION: Galapagos Islands and Isla del Coco (Robertson \& Allen, 2015; Fourriére et al., 2017).

Occurrences at Isla del Coco (This study): 45-90 m at Everest, afternoon and morning.

Previous RePORTS From Isla del Coco: Reported by Fourriére et al. (2017) as a shallow-water species. Previously known only from the Galapagos Islands.

ReMARKs: Observed only at Everest. Known maximum depth increases by $60 \mathrm{~m}$. 


\section{Family Myrocongridae}

Myroconger nigrodentatus Castle \& Béarez, 1995

Orange Conger-moray / Morena-congrio anaranjada

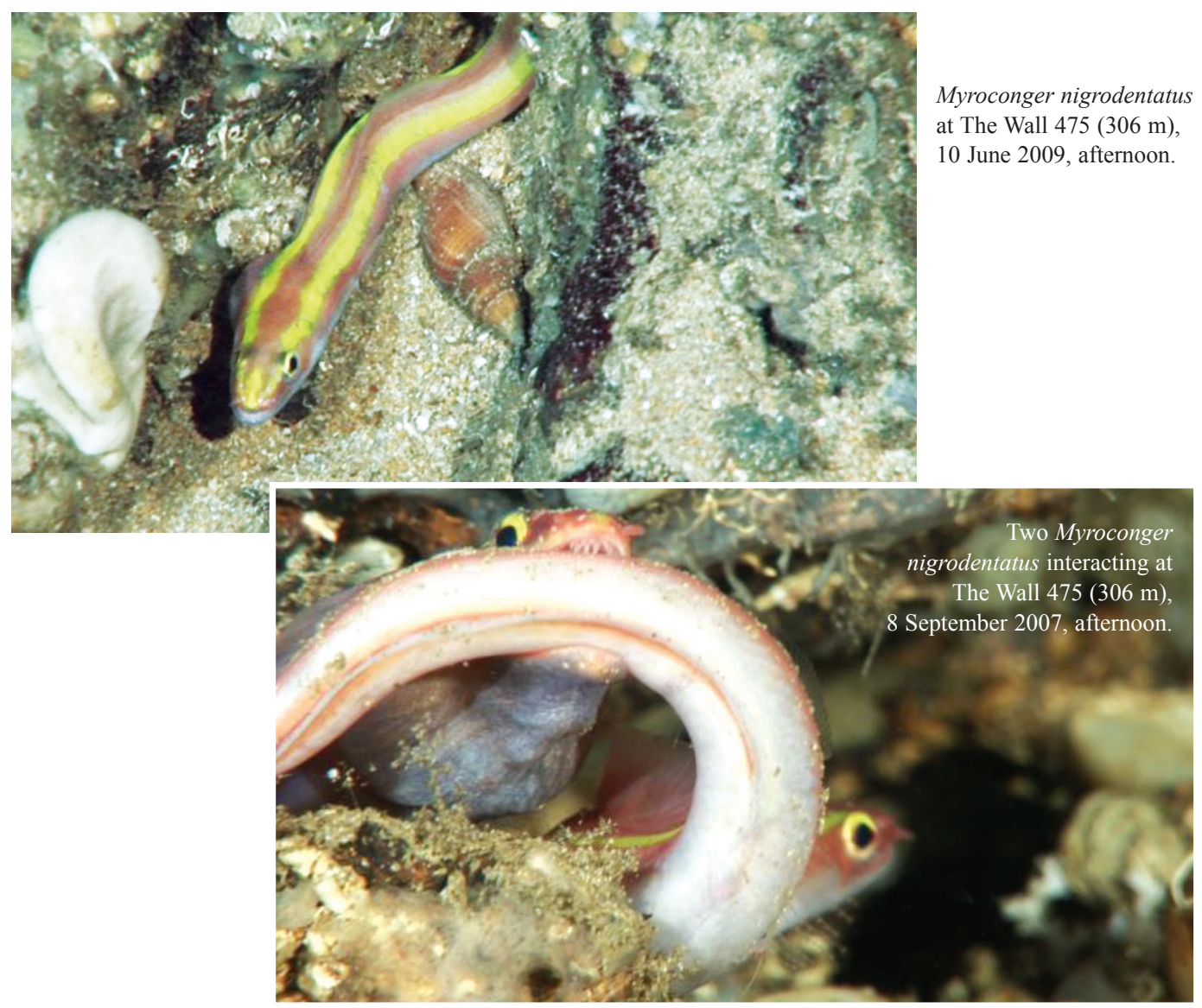

DeSCRIPTIOn: Body elongate and very compressed. Anterior nostril in a tube, posterior nostril, a hole. Dorsal fin raised and originating above gill opening. Three rows of sharp teeth on each jaw and a single row on upper inner part of the mouth. Body and fins orange with a bright yellow stripe from eye back along body above midline (Robertson \& Allen, 2015). Max length: $36 \mathrm{~cm}$. Depth range: 50-458 m (Robertson \& Allen, 2015), 220-345 m (McCosker \& Rosenblatt, 2010).

Worldwide Distribution: Mainland Ecuador, Galápagos Islands and Isla del Coco (Robertson \& Allen, 2015).

Occurrences at Isla del Coco (This study): 150-220 m; Kili $(150 \mathrm{~m})$, The Edge $(220 \mathrm{~m})$ and The Wall 475 (306 m), afternoon; Piedra 165 (150-170 m) and Kili 2 (180 m), morning.

Previous RePorts from Isla del Coco: First reported in deep waters at Isla del Coco by McCosker and Rosenblatt (2010). Reported by Starr et al. (2012b) at more than $50 \mathrm{~m}$, and by Fourriére et al. (2017). 


\section{Family Muraenidae}

Gymnothorax angusticeps (Hildebrand \& Barton, 1949)

Wrinkled Moray / Morena arrugada

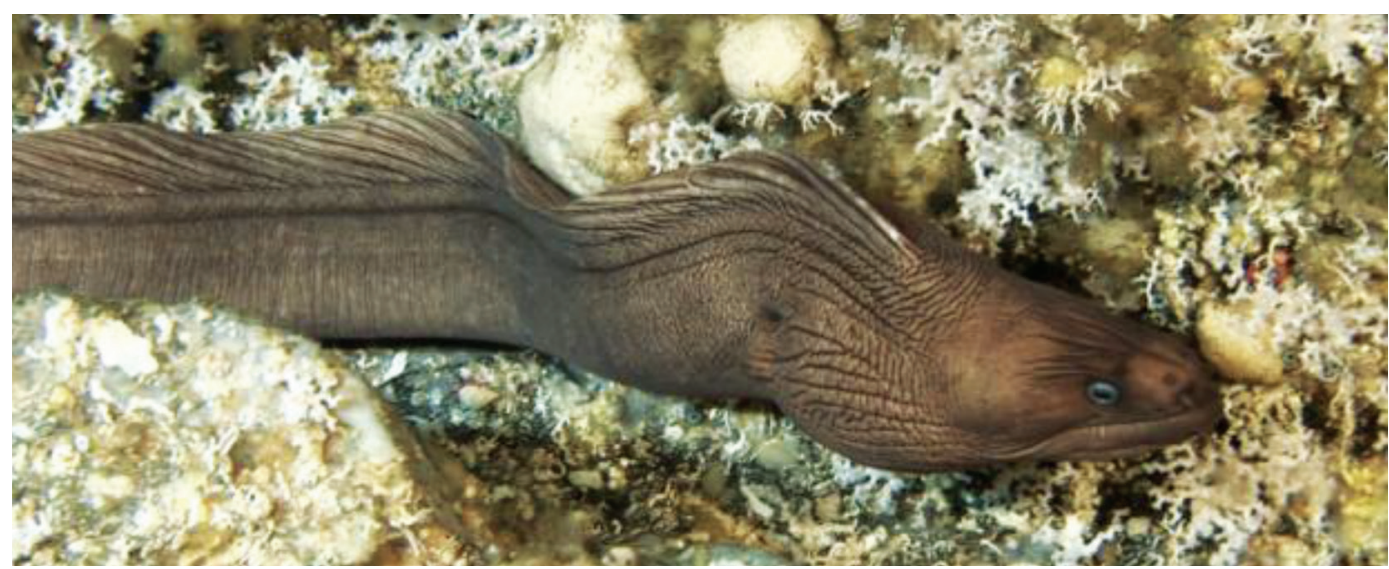

Gymnothorax angusticeps at Kili 2 (180 m), 14 July 2007, afternoon.

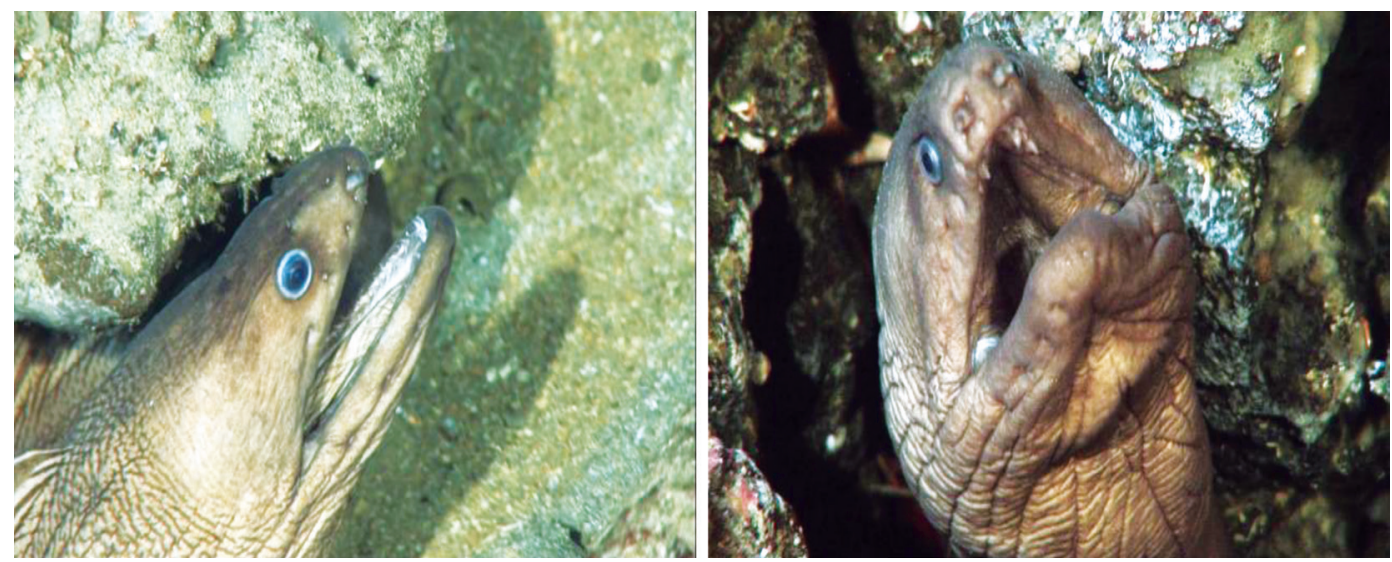

Gymnothorax angusticeps at Piedra 165 (150-170 m), 1 July 2007, morning;

near Piedra Drop (180 m), 15 May 2009, morning.

DESCRIPTION: Body brown, head and gill opening slightly darker; body, tail and fins a lighter tone. Teeth slightly serrated (Böhlke \& Smith, 2002). Skin of body with wrinkles, darker lines within wrinkles and dorsal fin. Head large, snout long, anterior nostrils tubular. Teeth on jaws and vomer. Length: to $98 \mathrm{~cm}$ (Robertson \& Allen, 2015). Depth range: 1-200 m (McCosker \& Rosenblatt, 2010).

Worldwide distribution: Pacific Ocean, Perú (Smith, 1994), Malpelo, Galápagos Islands and Isla del Coco (McCosker \& Rosenblatt, 2010).

Occurrences at Isla del Coco and Las Gemelas Seamount (This study): 80-180 m; Everest (80 $\mathrm{m})$, Piedra $165(150-170 \mathrm{~m})$ and Las Gemelas $3(170 \mathrm{~m})$, morning and afternoon; at sites close to Kili 2 and at Piedra Drop (around $180 \mathrm{~m}$ ).

Previous RePORTS From IsLa Del Coco: Reported by McCosker and Rosenblatt (2010) along rocky outcrops between 150-200 m, and by Fourriére et al. (2017). 


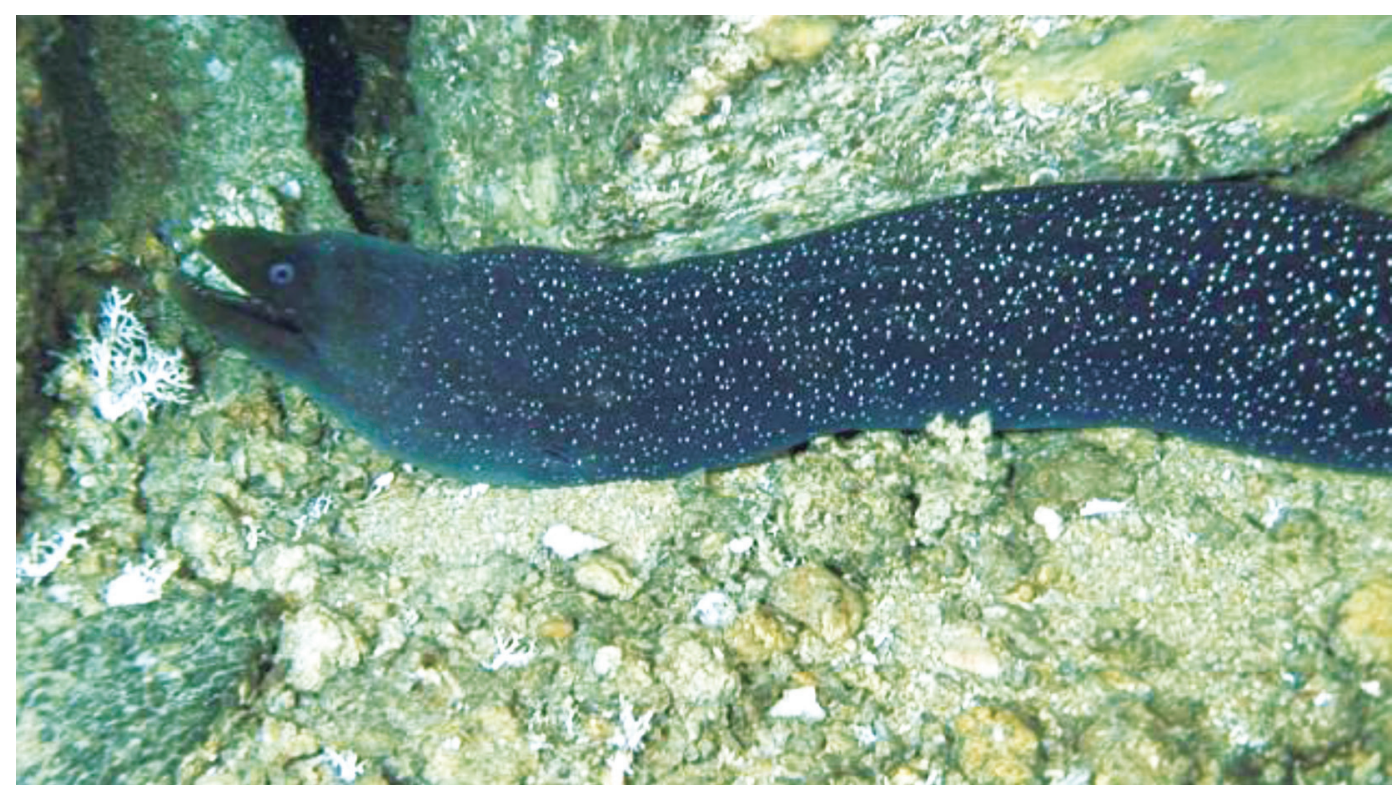

Gymnothorax dovii at Piedra 165 (160 m), 1 July 2007, afernoon.

DESCRIPTION: Moderately robust; body dark-brown to black, with numerous minute white spots (McCosker \& Rosenblatt, 1995; Bussing \& López, 2005). Head slender and snout pointed; rear nostril not tubular, with a raised rim (Robertson \& Allen, 2015). Maximum length: $170 \mathrm{~cm}$. Depth range: $3 \mathrm{~m}$ to at least $36 \mathrm{~m}$ (Humann \& Deloach, 1993), reported at $70 \mathrm{~m}$ by Robertson \& Allen (2015).

Worldwide Distribution: Eastern Pacific (McCosker \& Rosenblatt, 2010). Costa Rica to Colombia and oceanic islands (Garrison, 2005).

Occurrences at Isla del Coco (This study): 45-160 m, Everest (45-90 m) and Piedra 165 (160 $\mathrm{m})$, afternoon.

Previous RePorts From Isla del Coco: Common in shallow waters above coral reefs and rocky bottoms (Garrison, 2005), and by Fourriére et al. (2017) as a shallow water species.

Remarks: Known maximum depth increases from $70 \mathrm{~m}$ to $160 \mathrm{~m}$. 


\section{Gymnothorax sp. A \\ Moray / Morena}

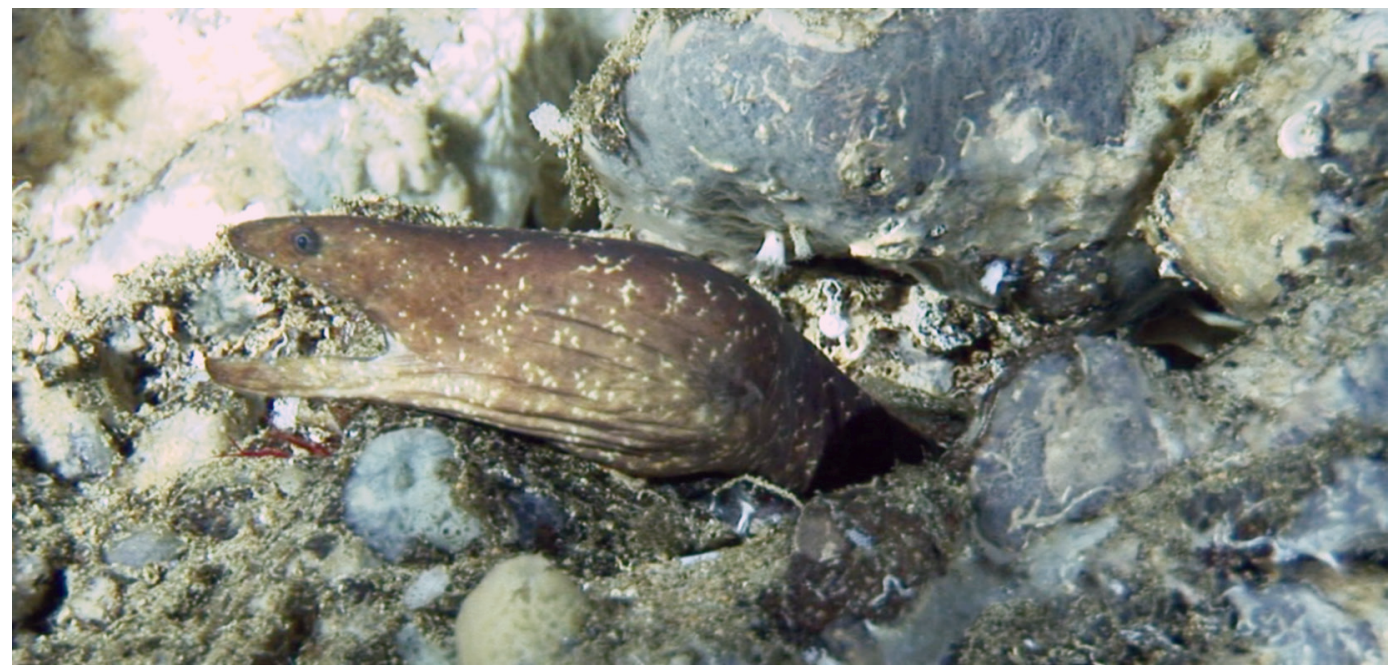

Gymnothorax sp. A near Piedra Drop (230 m), 2 December 2010, morning.

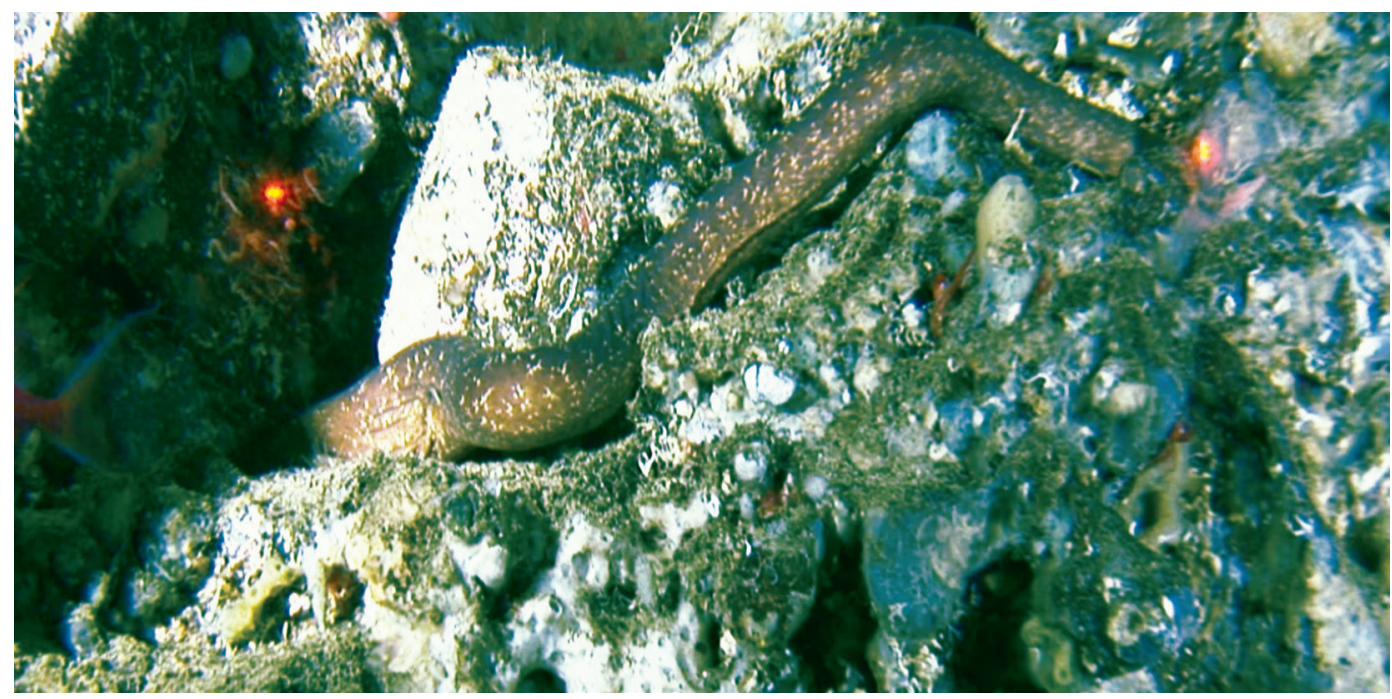

Gymnothorax sp. A near Piedra Drop (230 m), 2 December 2010, morning. Laser beams are $33 \mathrm{~cm}$ apart.

DESCRIPTION: Body elongate and brown, covered with thin irregular paler blotches.

Occurrences at Isla del Coco (This study): 180-230 m at sites close to Piedra Drop and The Edge.

Previous Reports from Isla Del coco: Genus present at Isla del Coco (McCosker \& Rosenblatt, 2010). 


\section{Gymnothorax sp. B}

Moray / Morena

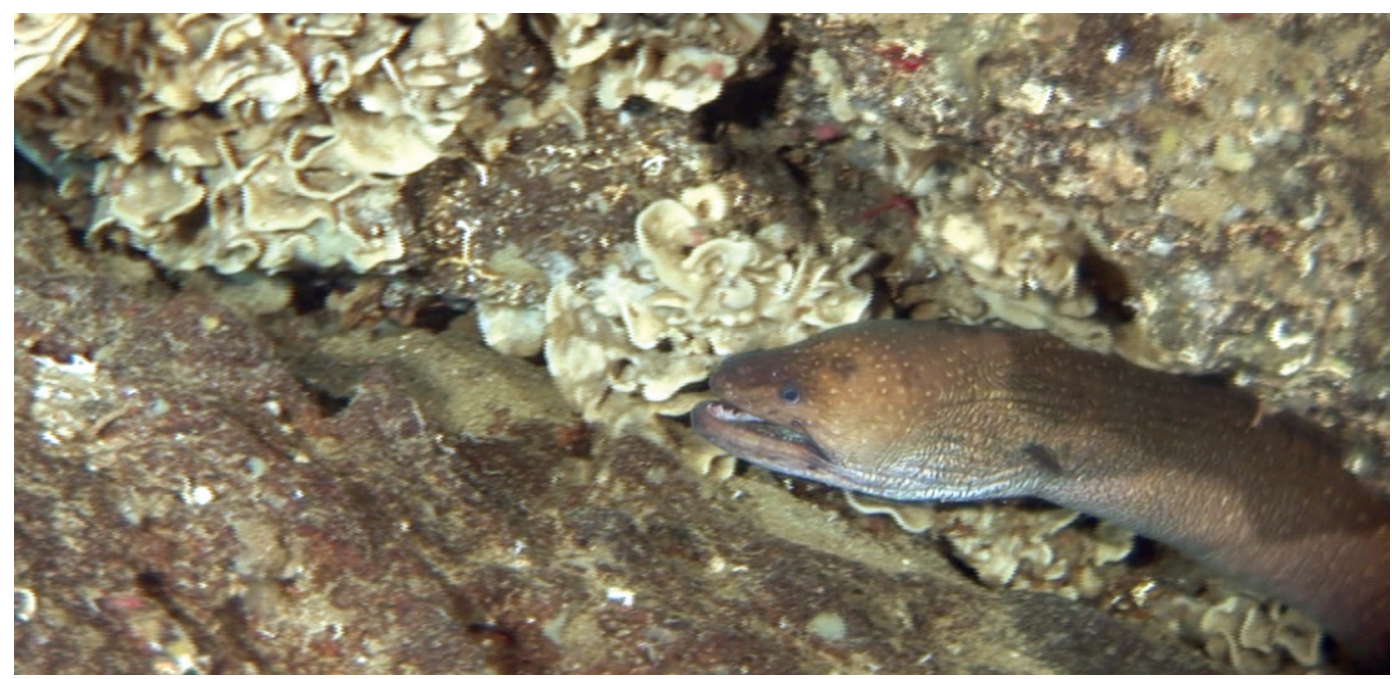

Gymnothorax sp. B, at Kili (130-170 m), 4 February 2007, in the morning.

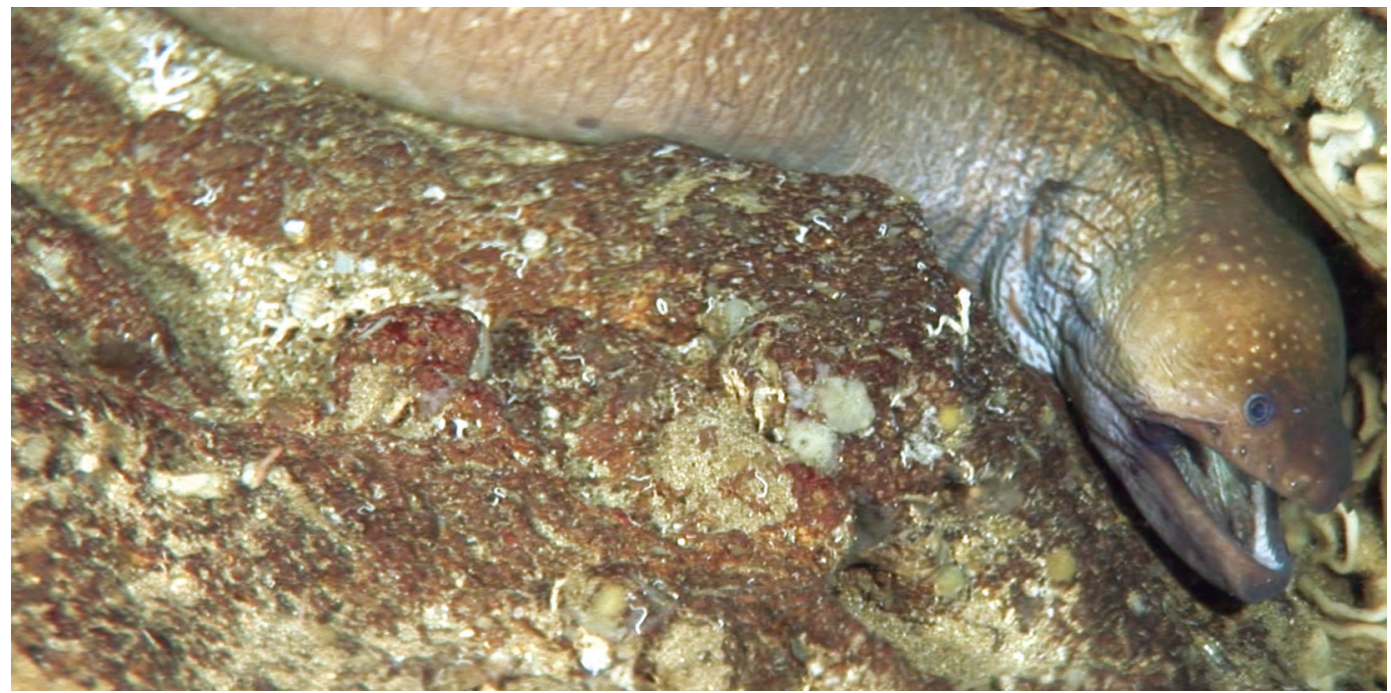

Gymnothorax sp. B, at Kili (130-170 m), 4 February 2007, in the morning.

DESCRIPTION: Body brown and elongate with pale spots.

Occurrences at Isla del Coco (This study): 130-170 m, Kili (130 m) and Piedra 165 (150-170 m), morning and afternoon.

Previous Reports: Genus present at Isla del Coco (McCosker \& Rosenblatt, 2010). 


\section{Gymnothorax sp. C}

Moray / Morena
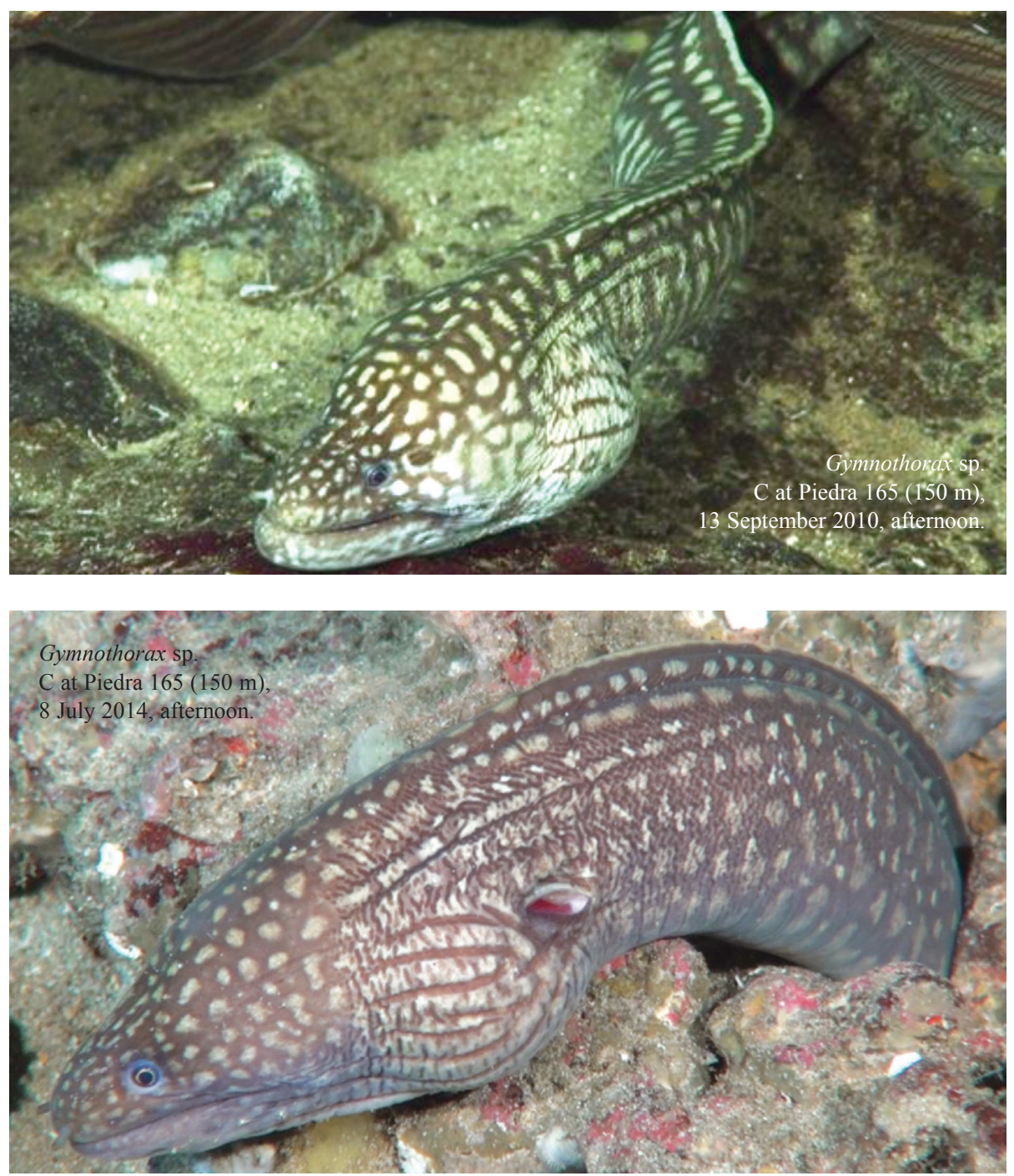

DESCRIPTION: Body brown and elongate, with rows of irregular white blotches. Dorsal fin with a row of white blotches and a white fin edging.

Occurrences at Isla del Coco (This study): Piedra 165 (150-170 m) morning and afternoon.

Previous Reports from Isla del Coco: This is probably a new species.

REMARKS: Lives in crevices in rocks. Hunts at night, apparently aided by the light of the submersible, when it feeds on Protonogrammus multifasciatus. 


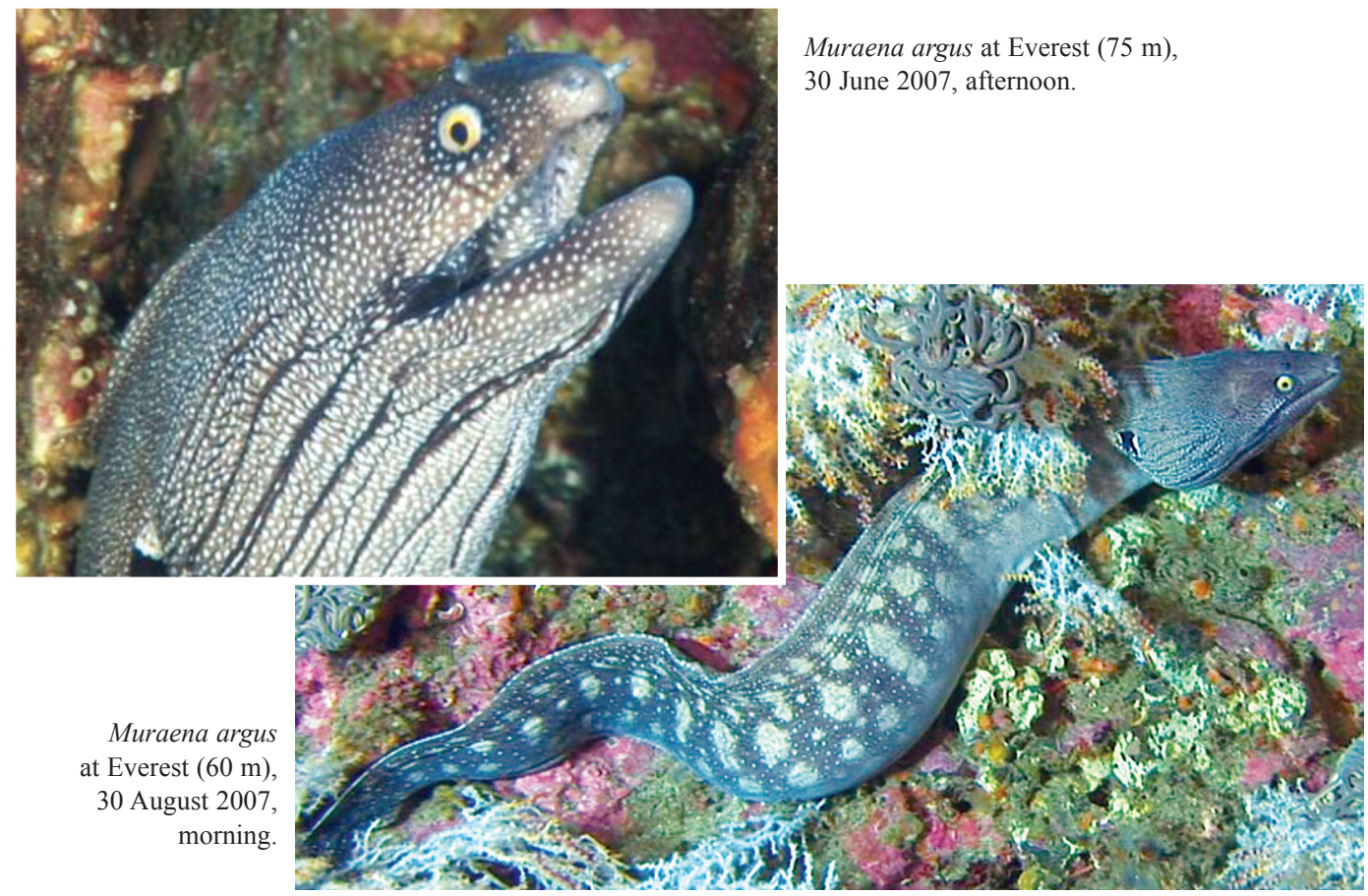

DesCRIPTION: Body with three rows of large yellow blotches and numerous smaller white spots. Intense black spot covering gill opening (McCosker \& Rosenblatt, 1995, Bussing \& López, 2005). Distal margin of dorsal and anal fins whitish (Robertson \& Allen, 2015). Rear nostril tubular, eyes yellow. Attains a maximum length of $120 \mathrm{~cm}$ (McCosker \& Smith, 2004). Depth: in shallow water up to $60 \mathrm{~m}$ (Humann \& Deloach, 1993) and in deep waters in the Gulf of California from $80 \mathrm{~m}$ up to $120 \mathrm{~m}$ (Aburto-Oropeza, Caso, Erisman \&

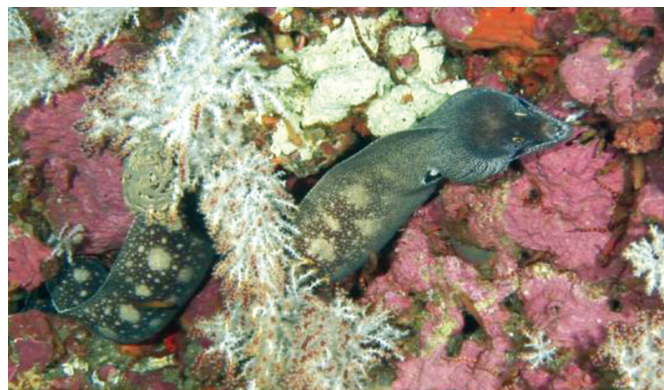

Muraena argus at Everest $(77 \mathrm{~m})$, 30 August 2007, morning. Ezcurra, 2010).

Worldwide distribution: Eastern Pacific (McCosker \& Rosenblatt, 2010). Baja California Sur, Gulf of California, Isla del Coco, Isla Malpelo, Isla Gorgona, Galápagos Islands, Isla la Plata (Ecuador) and Lobos de Afuera (Perú) (McCosker \& Smith, 2004).

Occurrences at Isla del Coco (This Study): 60-90 m; Everest (60-90 m) morning and afternoon; Bajo Manuelita (60 m), afternoon.

Previous Reports from Isla del Coco: Reported by Bussing and López (2005), at Manuelita Island on gravel rubble and sandy bottoms (Garrison, 2005), and by Fourriére et al. (2017). 


\section{Family Ophichthidae}

Leptenchelys vermiformis Myers \& Wade, 1941

Slender Worm-eel / Tieso esbelto

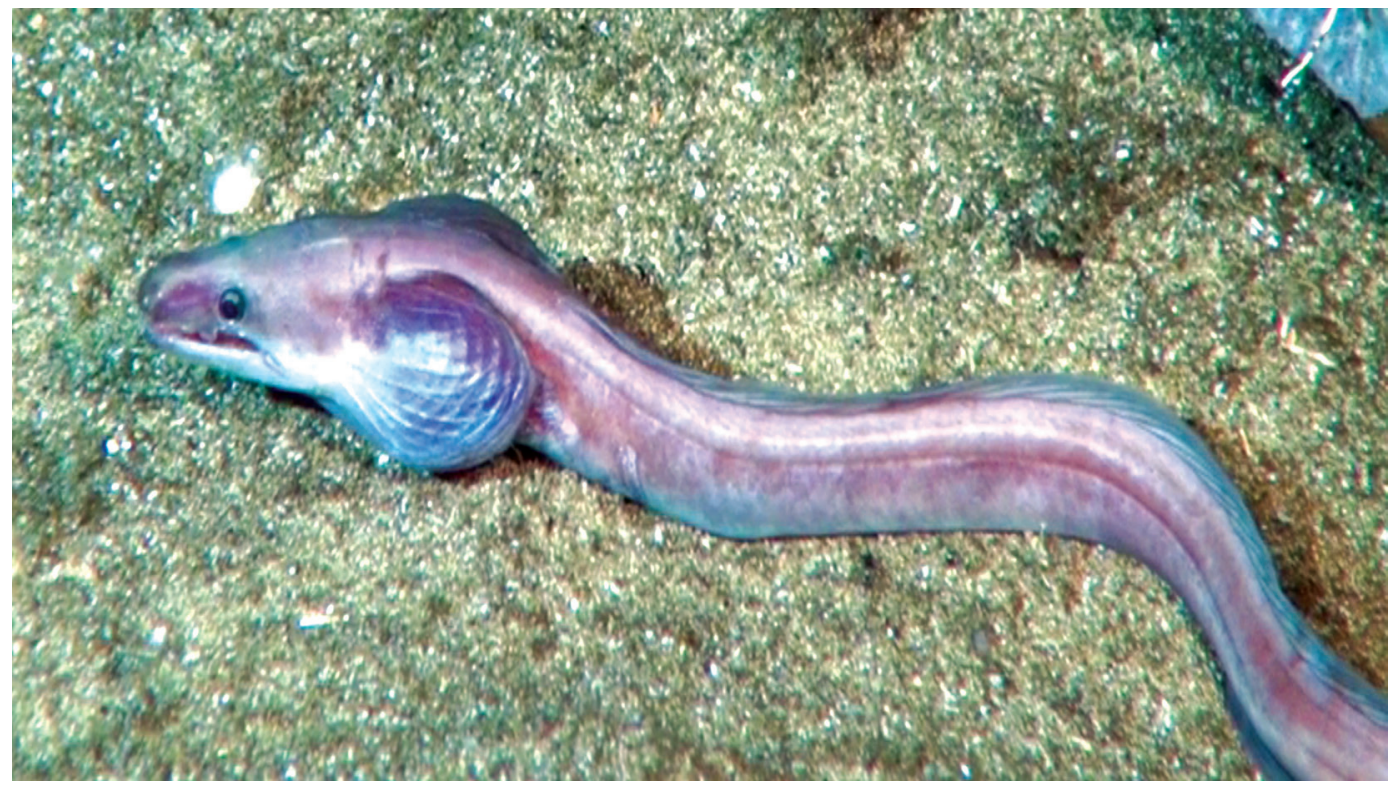

Leptenchelys vermiformis at The Wall 475 (270 m), 29 August 2014, morning.

DesCription: Body elongate, cylindrical and wormlike. Throat basket expanded. Gill openings curved and constricted, pectoral fins absent and a tail that is flexible at the tip. (McCosker, \& Rosenblatt, 1995, Robertson \& Allen, 2015). Usually uniform light yellow (Robertson \& Allen, 2015), the individuals found in the Isla del Coco with a pinkish appereance and tones of grey ventrally and dorsally. Up to $12 \mathrm{~cm}$ length. Depth range: 20-85 m (Robertson \& Allen, 2015).

worldwide Distribution: Reported from Costa Rica (Eastern Pacific) (McCosker \& Rosenblatt, 1995) to Mexico (Robertson \& Allen, 2015).

Occurrences at Isla del Coco and Las Gemelas Seamount (This study): 223-400 m, Las Gemelas $3(223 \mathrm{~m})$ and The Wall $475(250-400 \mathrm{~m})$.

Previous RePorts from Isla del Coco: This represents the first report for the island.

REMARKs: Known maximum depth increased by 315 m, from $85 \mathrm{~m}$ to $400 \mathrm{~m}$. 


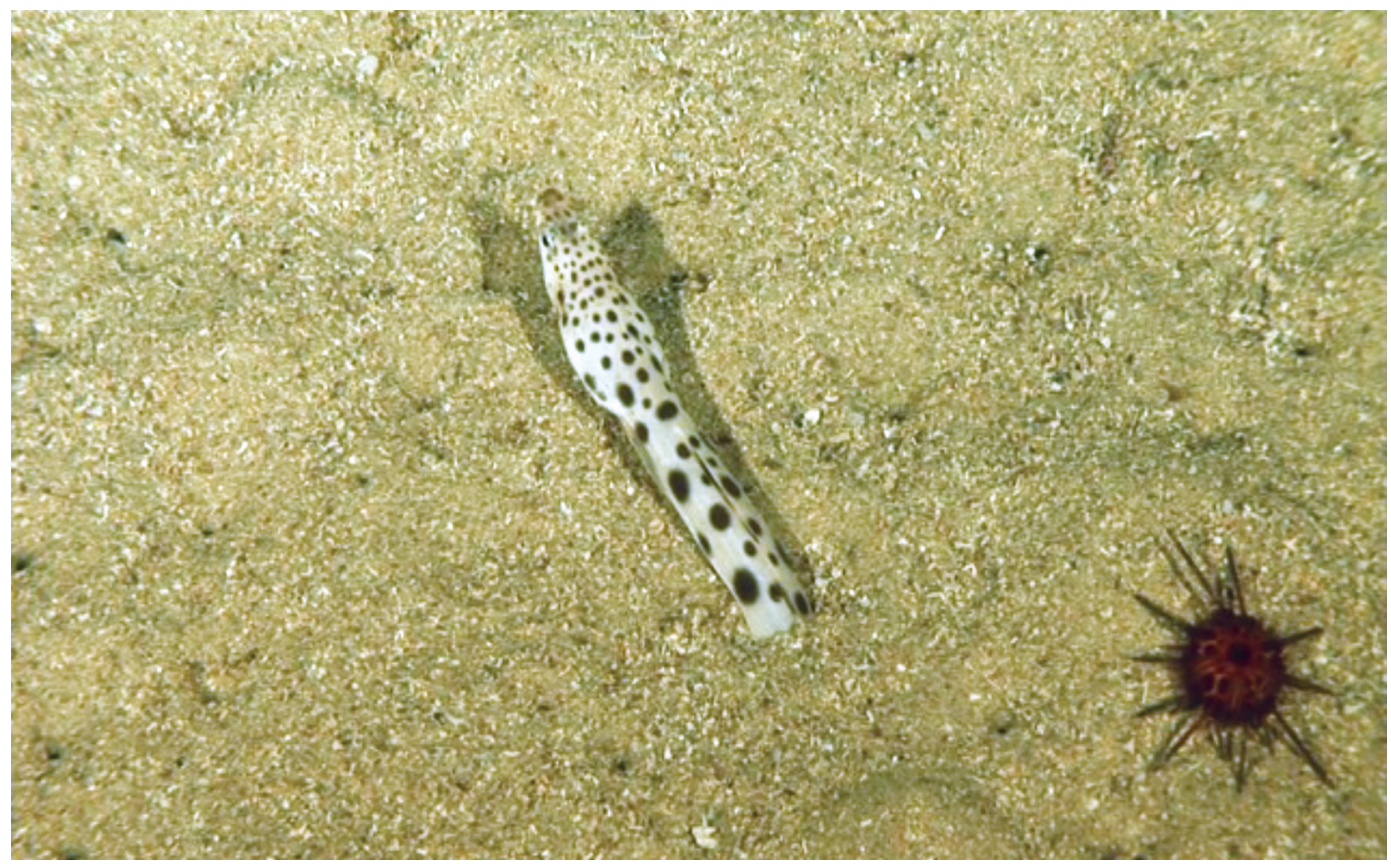

Ophichthus rugifer at Arena (110 m), 16 September 2009, afternoon.

Description: Head with dorsal BRown round blotches. A series of brown spots from mid-flank to dorsal base. Dorsal fin margin with series of brown streaks; dorsal and pectoral fins with black blotches in adults (McCosker \& Rosenblatt, 1995). Dorsal and anal fins expanded near tail tip which is pointed at its tip (Bussing \& López, 2005). Half the tail yellow. Depth: from shallow water, up to $200 \mathrm{~m}$ (McCosker \& Rosenblatt, 1995).

Worldwide Distribution: Galápagos Islands and Isla del Coco (McCosker \& Rosenblatt, 1995).

Occurrences at Isla del Coco (This study): 110-180 m, Arena (110 m), Piedra 165 (170 m) and insular shelf $(180 \mathrm{~m})$.

Previous Reports from Isla del Coco: Rare in shallow waters (Bussing \& López 2005, Garrison, 2005), and by Fourriére et al. (2017). 
Quassiremus evionthas (Jordan \& Bollman, 1890)

Galapagos Snake-eel / Tieso pecoso

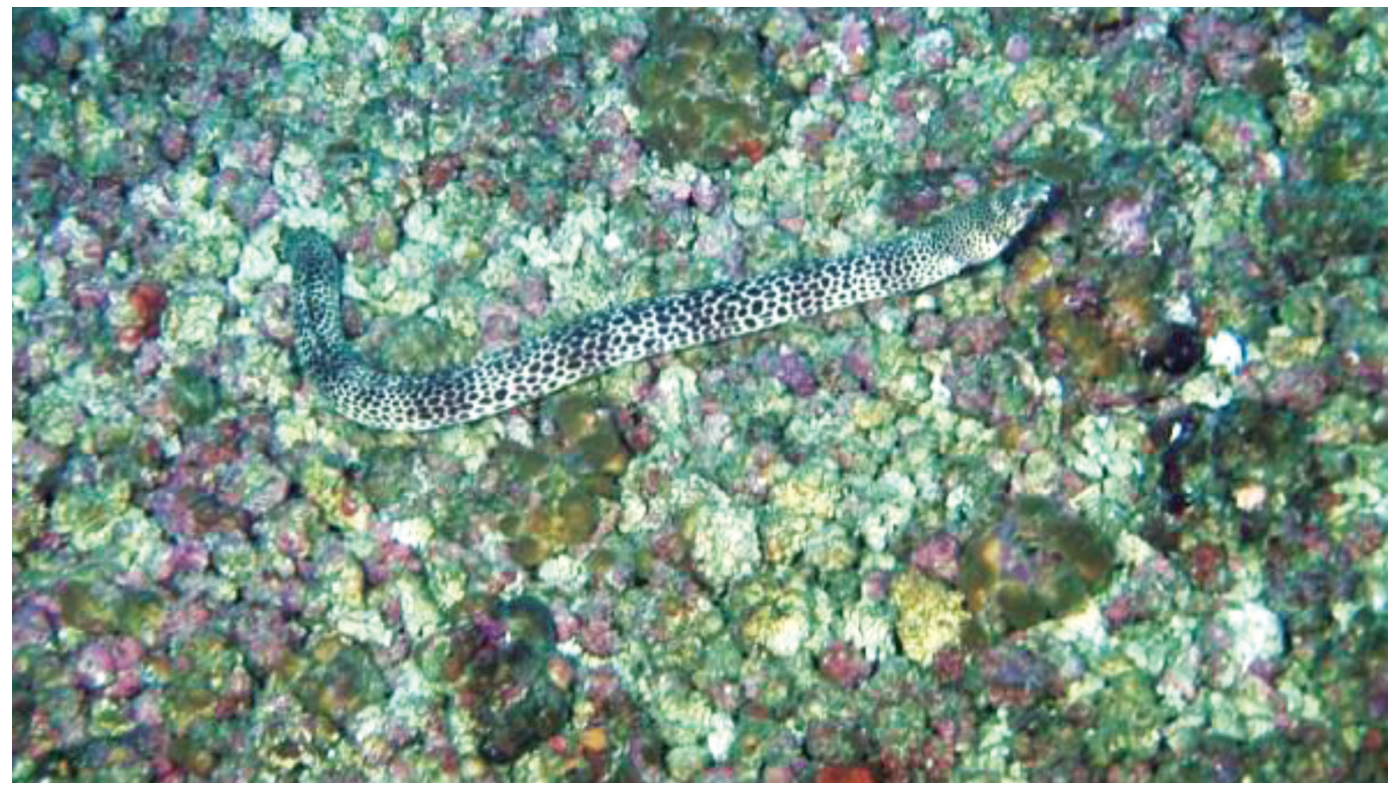

Quassiremus evionthas at Everest (72 m), 13 July 2007, afternoon.

DesCRIPTIOn: A yellowish eel with head, body and tail covered with black spots, with areas of larger and darker spots, forming saddles. Dorsal fin origin well behind gill opening (Bussing \& López, 2005). Front nostril tubular, teeth in simple rows on jaws and roof of mouth (Robertson \& Allen, 2015). Golden eyes, small pectoral fins (Garrison, 2005). Maximum length close to $71 \mathrm{~cm}$. Depth range: 3-30 m (Humann \& Deloach, 1993; Robertson \& Allen, 2015).

Worldwide Distribution: Galápagos Islands (Jordan \& Bollman, 1890; McCosker \& Rosenblatt, 2010) and Isla del Coco (Bussing \& López, 2005; Garrison, 2005).

Occurrences At Isla del Coco (DeEPSEE): 40-80 m, Bajo Manuelita (40-60 m) and Everest (45-80 $\mathrm{m})$, afternoon.

Previous Reports from Isla del Coco (This study): Reported by Bussing and López (2005) at Manuelita and at Roca Langosta (Garrison, 2005), and by Fourriére et al. (2017).

REMARKS: No PUblished REPORTS FROM DEEP WATERS FOR THE SPECIES. MAXIMUM DEPTH REPORTED By Humann and Deloach (1993) of $30 \mathrm{~m}$, extended to $80 \mathrm{~m}$. 
Ophichthidae, unidentified

Snake-eel / Tieso

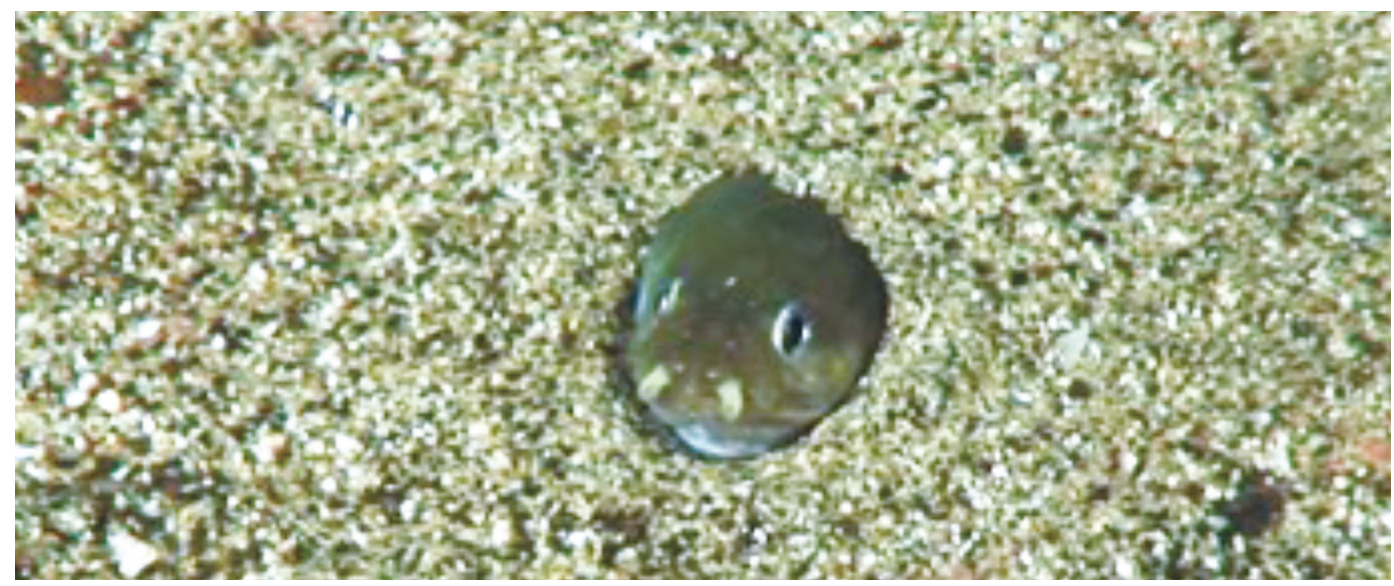

Snake-eel unidentified at Las Gemelas 1 (250 m), 14 September 2009, morning.

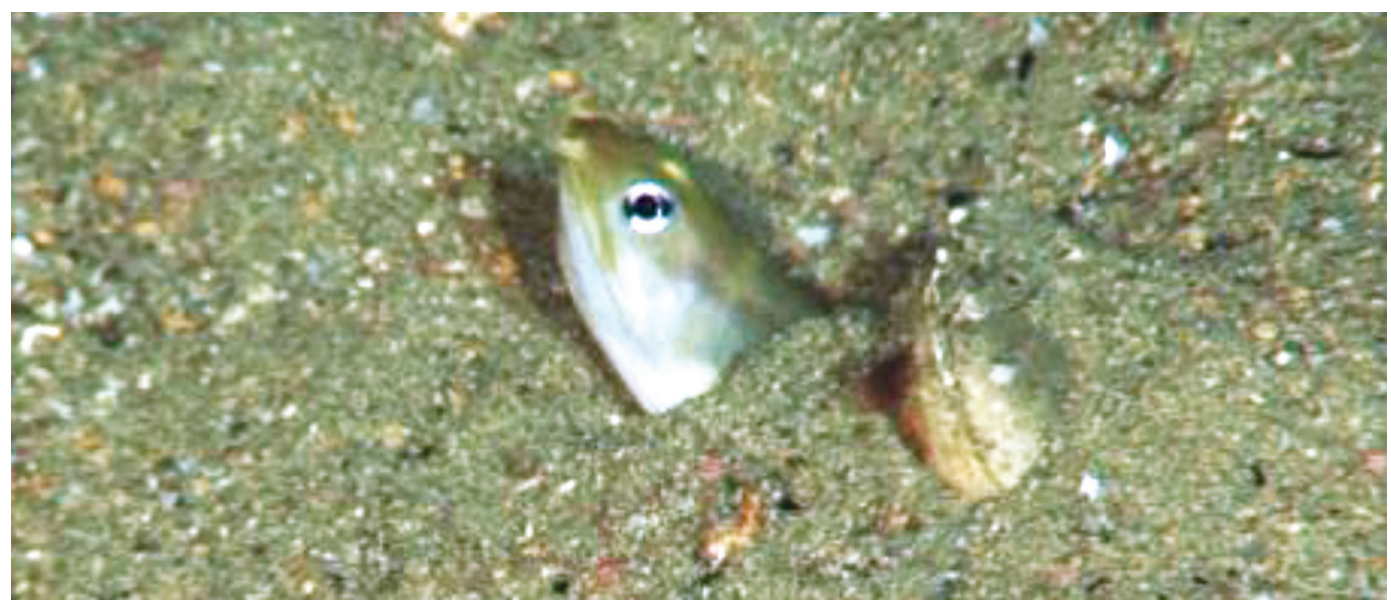

Snake-eel unidentified at The Edge (200 m), 15 May 2009, morning.

DesCriPTIOn: Body elongate, pelvic fins absent, pectoral fins usually present. Tail tip pointed. Gill basket expanded. Narrow gill openings (Robertson \& Allen, 2015). However, some of those features are not observed in the photograph as the individuals are buried in the sand.

Occurrences at Isla del Coco and Las Gemelas Seamount (This study): 150-250 m; Piedra 165 (150-170 m), The Edge (200 m) and Las Gemelas 1 (250 m), morning; Las Gemelas 2 (170-200 $\mathrm{m})$, afternoon.

Previous RePorts From Isla del Coco: Other snake eel species are represented at Isla del Coco (McCosker \& Rosenblatt, 2010). 


\section{Family Congridae}

Bathycongrus varidens (Garman, 1899)

Largehead Conger / Congrio cabezón

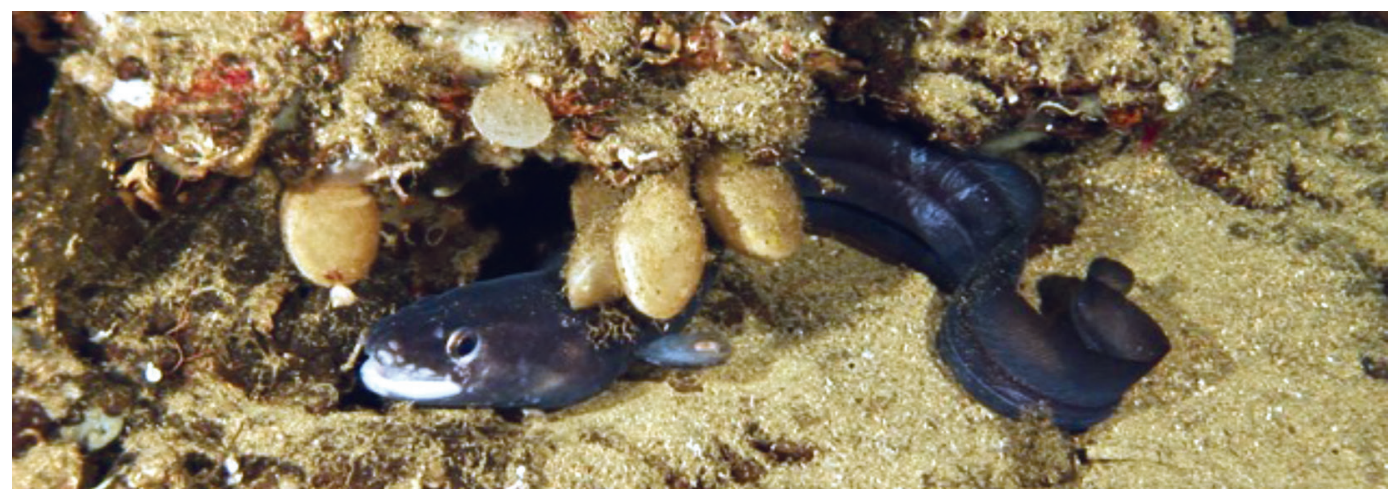

Bathycongrus varidens at The Wall 475 (304 m), 3 November 2009, morning.

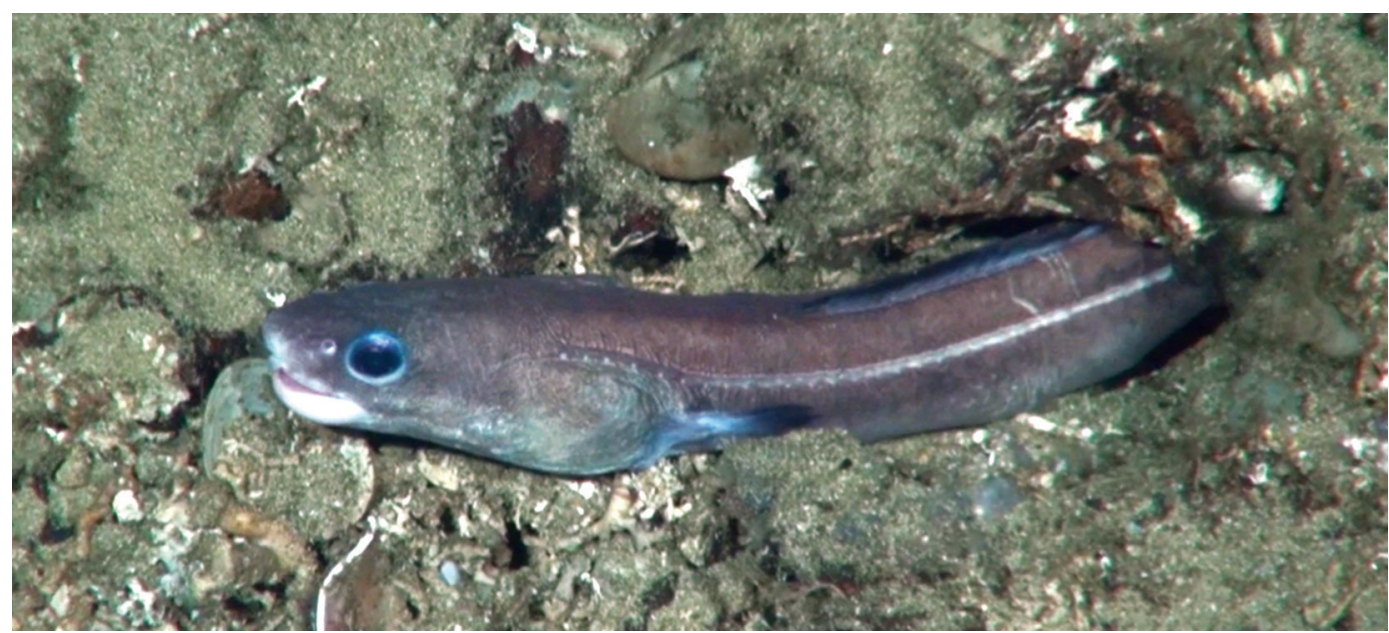

Bathycongrus varidens at The Wall 475 (230 m), October 21, 2014, morning.

DESCRIPTION: Body elongate and blackish with rows of melanophores alongside; dorsal and anal fins with a narrow border of black (Raju, 1985). Head longer than trunk, i.e.: longer than the distance from gill oppening to anus (Smith, 1995). Up to $1 \mathrm{~m}$ in length (Smith, 1995). Depth range: 165-935 m (Smith, 1995).

Worldwide Distribution: From southern Canada to Chile (Smith, 1995).

Ocurrences at Isla del Coco (This study): 215-304 m, Piedra Drop (215 m) and The Wall 475 (230-304 m), morning and afternoon.

Previous RePorts from Isla del Coco: Species presence reported by Starr et al. (2012b) at more than $50 \mathrm{~m}$ deep, and by Fourriérre et al. (2016). 


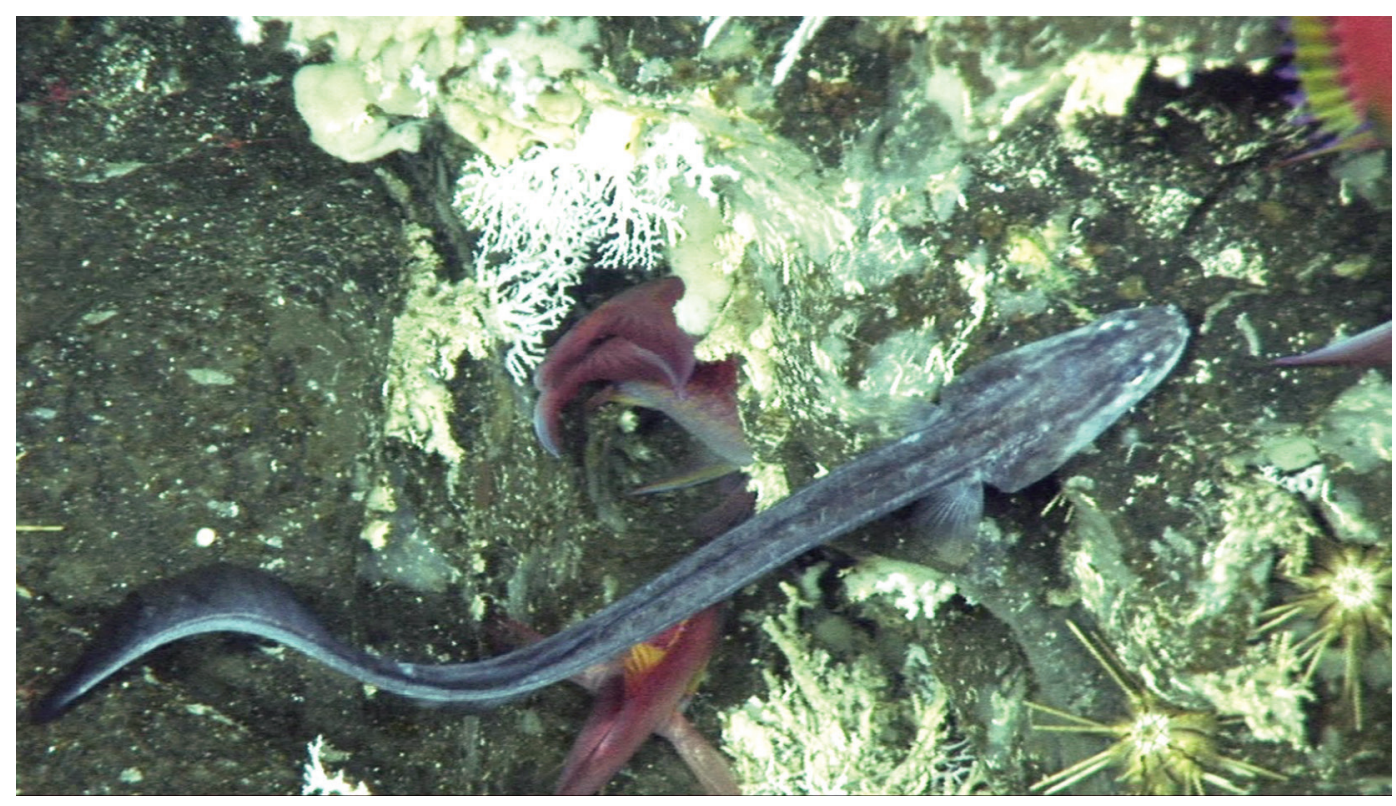

Congridae, unidentified at Las Gemelas 1 (250 m), 14 September 2009, morning.

DESCRIPTION: Body elongate, cylindrical, compressed posteriorly, characteristic of many Congridae (Smith, 1995). Bluish-grey in colour.

WORLDWIDE DISTRIBUTION: Most species of congrids live on the continental shelf or slope (Smith, 1995).

Occurrences at Las Gemelas Seamount (This study): Las Gemelas 1 (250 m).

Previous Reports from Isla del coco: Family present at Isla del Coco (McCosker \& Rosenblatt, 2010). 
Congridae, unidentified sp. B

Conger Eel / Congrio

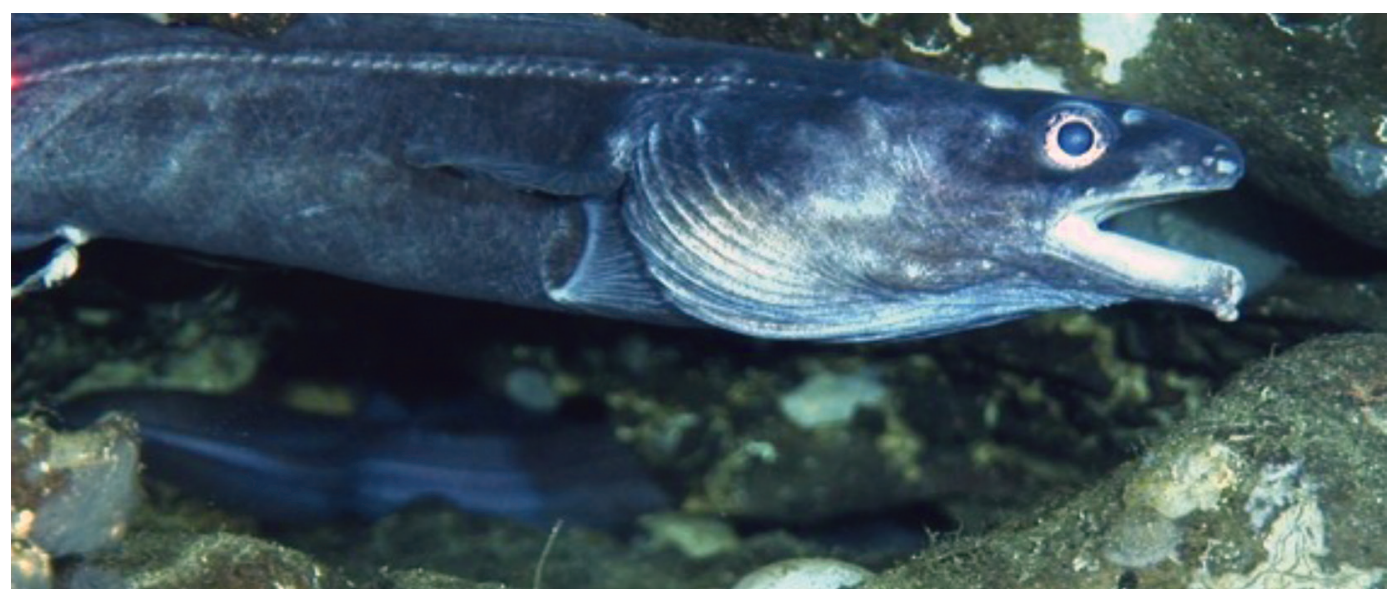

Congridae, unidentified at The Wall 475 (270 m), 28 September 2009, afternoon.

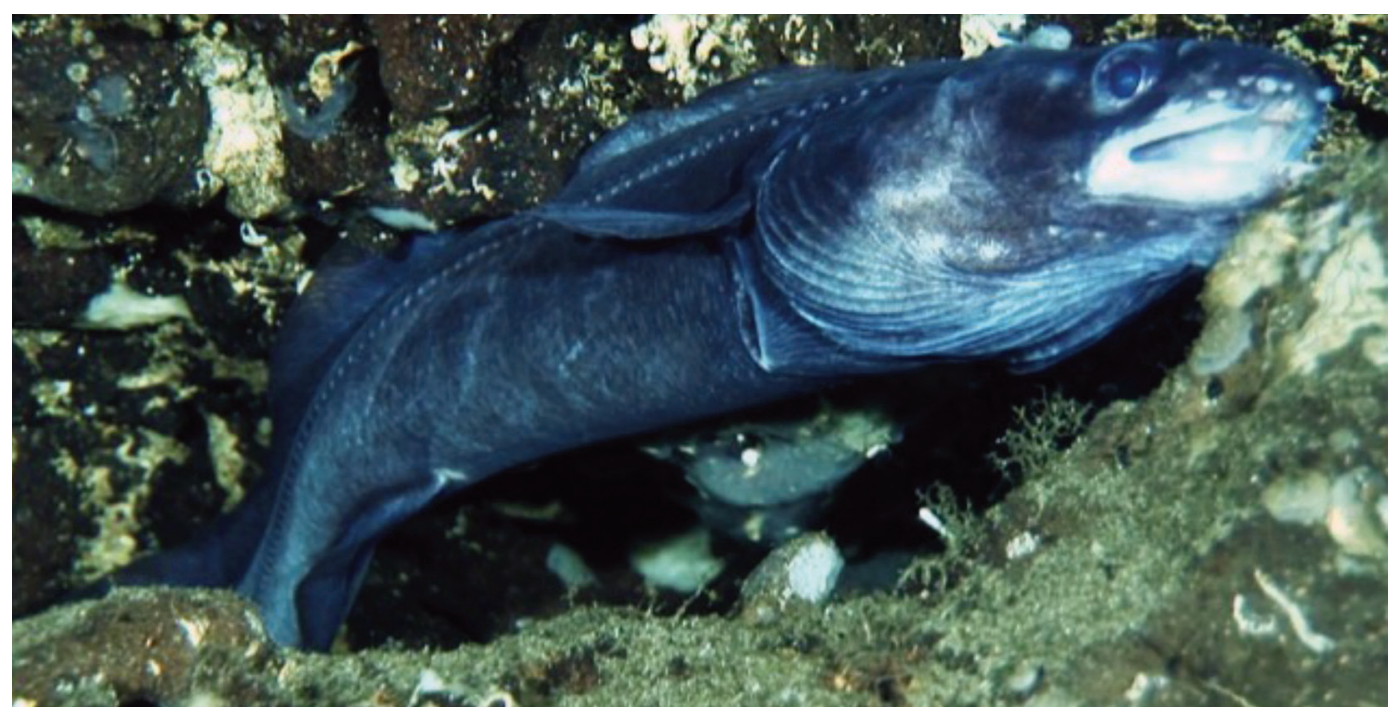

Congridae, unidentified at The Wall 475 (270 m), 28 September 2009, afternoon.

DesCRIPTIOn: Grey opaque fish, elongate with cylindrical body compressed posteriorly. Corner of mouth beneath eye, dorsal and anal fins confluent with caudal fin. Dorsal origin before pectoral, characteristic of the Congridae family (Smith, 1995).

Occurrences at Isla del Coco (This study): The Wall 475 (250-400 m), afternoon. Usually in caves and crevices.

Previous RePorts From Isla Del Coco: Congrids reported at more than $50 \mathrm{~m}$ and at Las Gemelas Seamount by Starr et al. (2012b). 


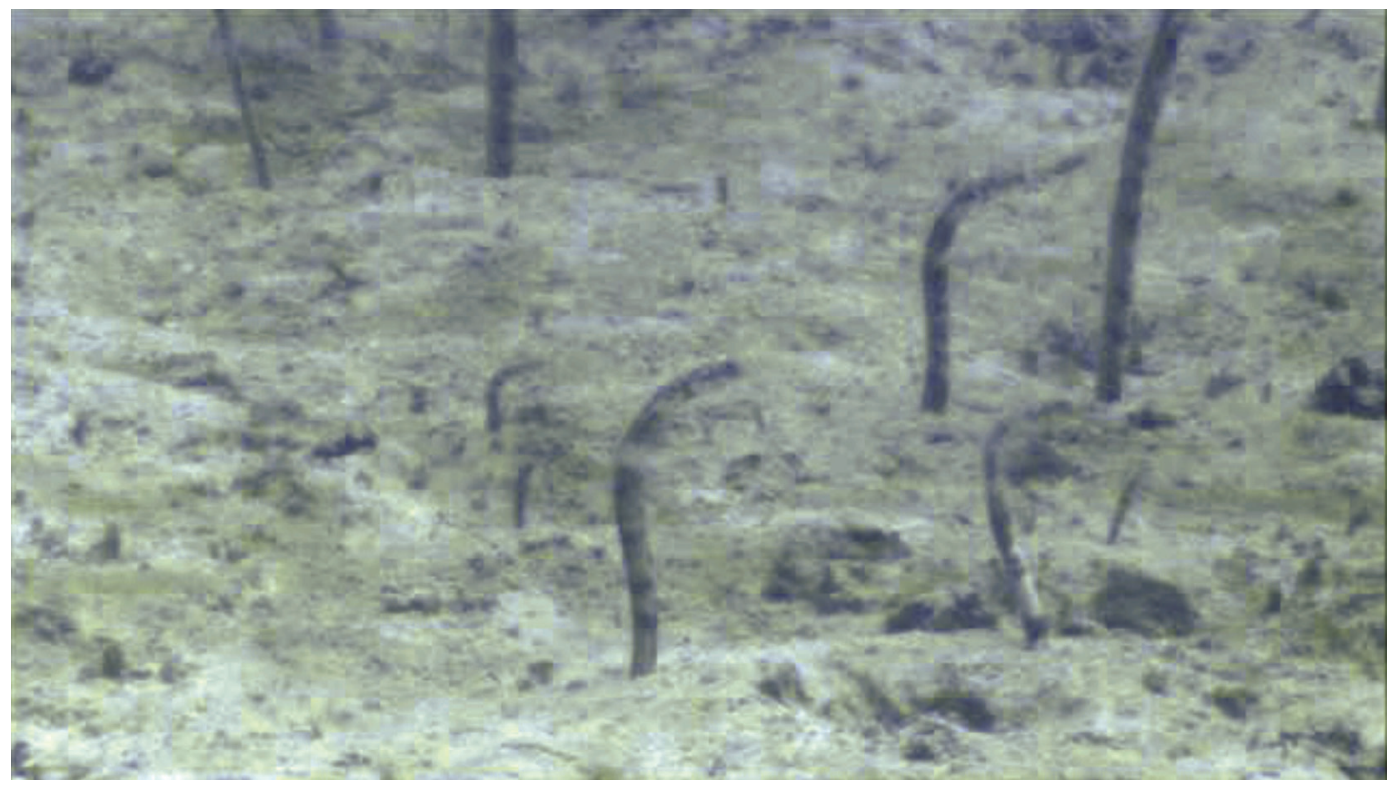

Heteroconger klausewitzi at Bajo Manuelita (60 m), 21 May 2007, morning.

DesCRIPTION: Body blackish, much lighter in juveniles, with irregular white blotches. Pectoral fin and branquial region dark brown (Castle, 1999). Body very elongate and cylindrical; lateral line pores outlined by white spots (Bussing \& López, 2005; Garrison, 2005). Size: 60-90 cm. Depth: from $3 \mathrm{~m}$ (J. McCosker, personal observation, September 2017) to $30 \mathrm{~m}$ (Castle, 1999).

WorldWide Distribution: Found ALONG CONTINENTAL MARGINS FROM COSTA RiCA TO ECUADOR, INCLUDing Malpelo, Isla Gorgona, Isla del Coco and Galápagos Islands (Castle, 1999; McCosker \& Rosenblatt, 2010; Robertson \& Allen, 2015).

Occurrences at Isla del Coco (This study): 50-90 m, Bajo Manuelita (50-60 m) and on route from Everest (60-90 m), afternoon.

Previous Reports from Isla del Coco: Reported by Bussing and López (2005), common in shallow waters sandy substrates (Garrison, 2005), and by Fourriére et al. (2017).

REMARKs: Known maximum depth increases from $30 \mathrm{~m}$ to $90 \mathrm{~m}$. 


\section{ORDER ATELEOPODIFORMES \\ Family Ateleopodidae \\ Guentherus altivela Osório, 1917 \\ Jellynose Fish / Trompa dulce}

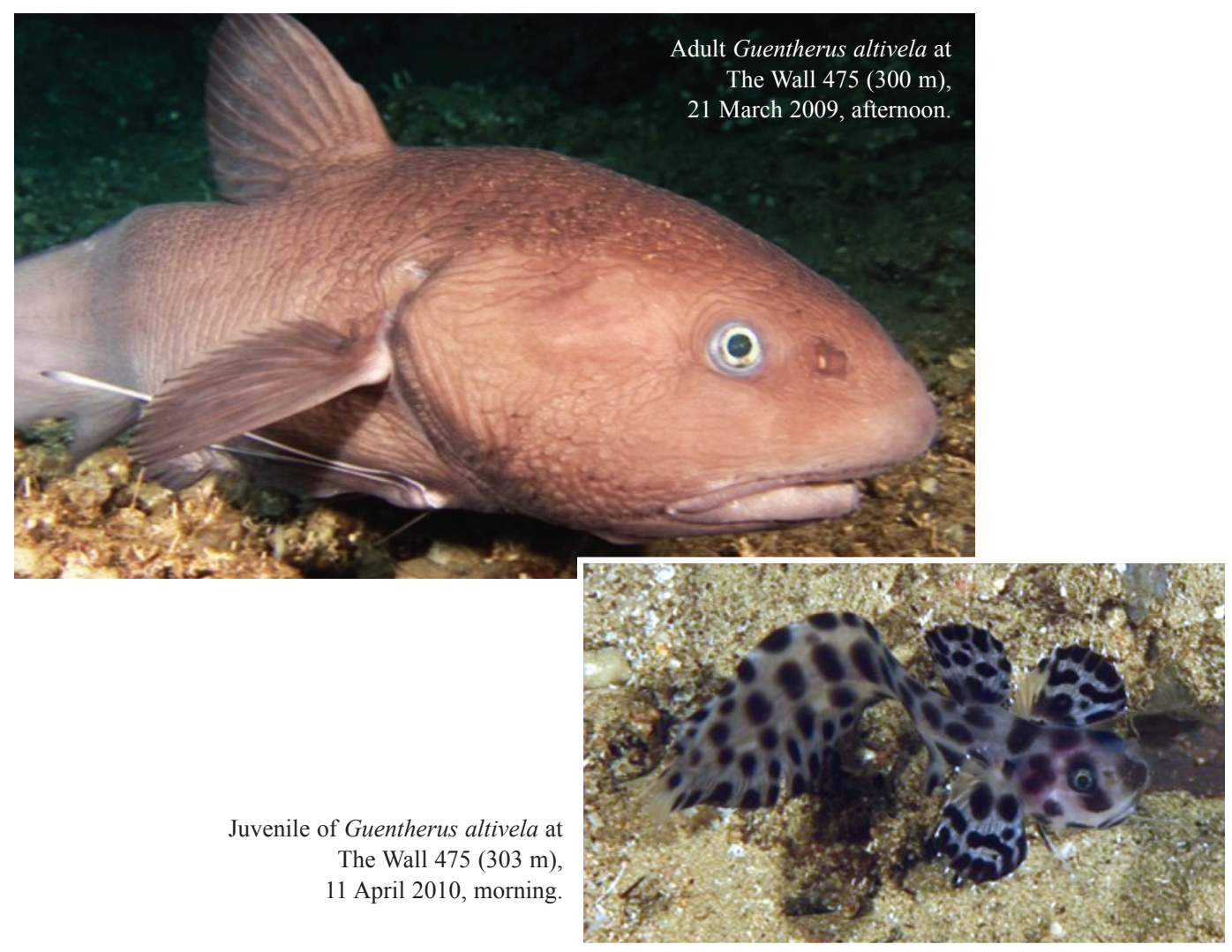

DESCRIPTION: Adults dark brown, with a large bulbous snout. Juveniles or in post-larval stage nearly transparent with black blotches along body and fins. Depth range: 220-700 m (Bussing \& López, 1977).

Worldwide distribution: Atlantic Ocean, from Portugal to Southeast Africa (Bussing \& López, 1977; McCosker \& Humann, 1996). Eastern Pacific (McCosker \& Rosenblatt, 2010): in Costa Rica at Cabo Blanco and Quepos; in Panamá at Punta Jaqué (Bussing \& López, 1977) and in the Galápagos Islands (McCosker \& Humann, 1996).

Occurrences at Isla del Coco and Las Gemelas Seamount (This study): 200-402 m, The Wall 475 and Piedra Drop (200 to $402 \mathrm{~m}$ ), and Las Gemelas 3 (262 m), morning and afternoon.

Previous reports from Isla del Coco: In deep waters at The Wall 475 (Cortés \& Blum, 2008), beyond $50 \mathrm{~m}$ (Starr et al., 2012b), and by Fourriére et al. (2017).

Remarks: Juveniles have been observed only at Piedra Drop at more than $300 \mathrm{~m}$ in the morning. They hover above the bottom with the dorsal fin undulating in a sinusoidal pattern. 


\section{ORDER AULOPIFORMES \\ Family Aulopidae \\ Aulopus sp. \\ Galapagos Flagfin / Lagarto de Galápagos}

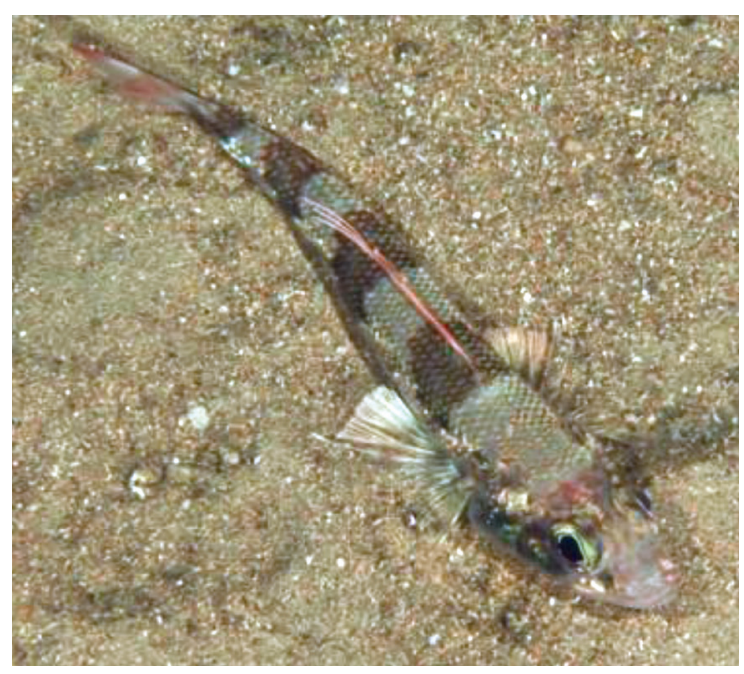

Aulopus sp. at Piedra 165 (170 m), 8 March 2008, afternoon.

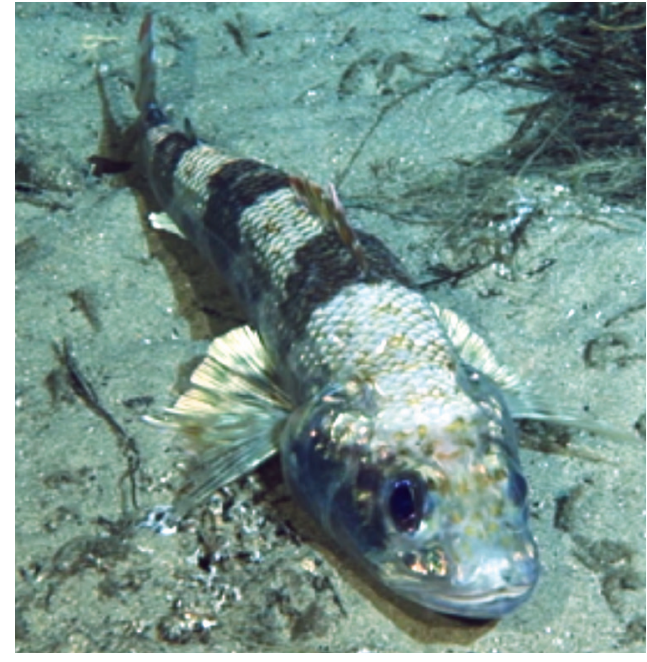

Aulopus sp. at The Edge (240 m), 18 September 2006, afternoon.

DesCription: Body slender and cylindrical. Head robust (Sommer \& Parín, 1995), eyes large, adipose fin present (Bussing \& López, 2005). Single dorsal fin high, located near mid-body, originating just posterior to the insertion of the pectoral fin (Thompson, 1998). Brown, usually with dark bands on upper body, a large dark blotch covering the opercle, upper half of the eye yellow (Robertson \& Allen, 2015). Body size up to $31 \mathrm{~cm}$ (Robertson \& Allen, 2015). Depth range: 305-513 m at Galápagos Islands (Thompson, 1998).

Worldwide Distribution: In the Eastern Tropical Pacific, Galápagos Islands and Isla del Coco (McCosker \& Rosenblatt, 2010).

Occurrences at Isla del Coco (This study): 150-240 m; site near Kili 2 (180 m), morning; The Edge $(240 \mathrm{~m})$ and The Wall $475(230-310 \mathrm{~m})$, afternoon, and Piedra 165 (150-170 m), morning and afternoon.

Previous Reports From Isla Del Coco: Aulopus sp. was reported by Starr et al. (2012b) as well as a southern population around the island (Robertson \& Allen, 2015).

Remarks: Thompson (1998) proposed that Aulopus bajacali Parin \& Kotlyar, 1984 was known from southern Baja California and the southwest part of the Gulf of California and population around Coco and Galápagos islands and mainland Ecuador. McCosker and Rosenblatt (2010: 189) reported that the late "Thompson (1998) initially recognized Galápagos and Cocos specimens as Aulopus bajacali Parin \& Kotlyar 1984, but subsequently determined that they were a distinct species (pers. comm. to J. E. McCosker, July 1999). In 1999 he designated CAS Galápagos specimens as the holotype and paratypes but his description was never published." Minimum known depth decreased from $305 \mathrm{~m}$ (Thompson, 1988) to $150 \mathrm{~m}$. 


\section{Family Chlorophthalmidae}

Chlorophthalmus mento Garman 1899

Greeneyes / Ojiverde robusto

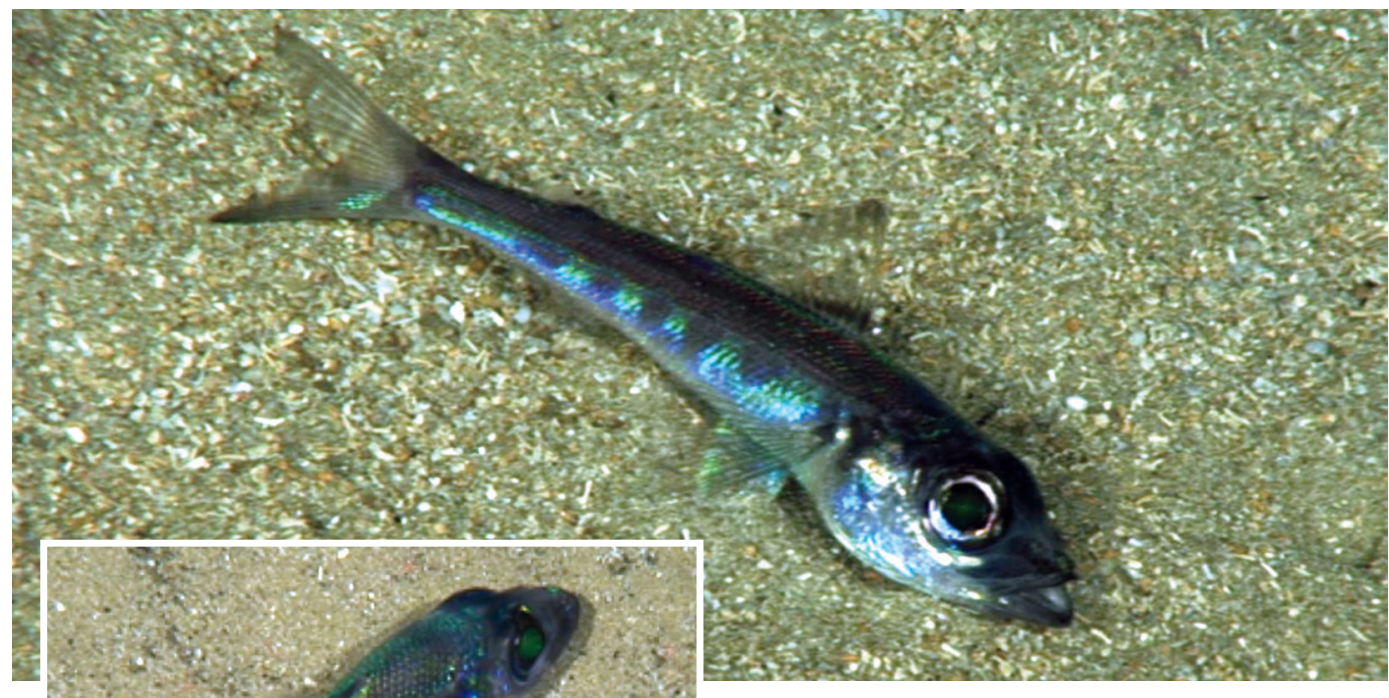

Chlorophthalmus mento at Boulders (311 m), 12 September 2009, afternoon.

Chlorophthalmus mento at Boulders (311 m), 20 June 2007, afternoon.

DESCRIPTION: Body brown to iridescent bluish-green, with dark blotches on the flank; very large shinny green eyes. Body cylindrical, compressed posteriorly, dorsal fin before middle of body, pelvic fins inserted just behind dorsal fin origin, adipose fin tiny, inserted opposite anal fin (Sulak, 1995). Size: 10-30 cm. Depth: 235-1260 m (Robertson \& Allen, 2015).

Worldwide Distribution: In the Eastern Tropical Pacific, Costa Rica to Perú, Galápagos Islands and Isla del Coco (Robertson \& Allen, 2015).

Occurrences at Isla del Coco and at Las Gemelas Seamount (This study): 250-311 m, Las Gemelas $1(250 \mathrm{~m})$ and Boulders $(311 \mathrm{~m})$, morning and afternoon.

Previous RePORTS FRom IsLA Del Coco: Chlorophthalmus mento was reported by Starr et al. (2012b) at Isla del Coco and Las Gemelas at more than $50 \mathrm{~m}$. 


\section{ORDER GADIFORMES \\ Family Moridae \\ Laemonema cf. gracillipes Garman, 1899 \\ Codling / Mora}

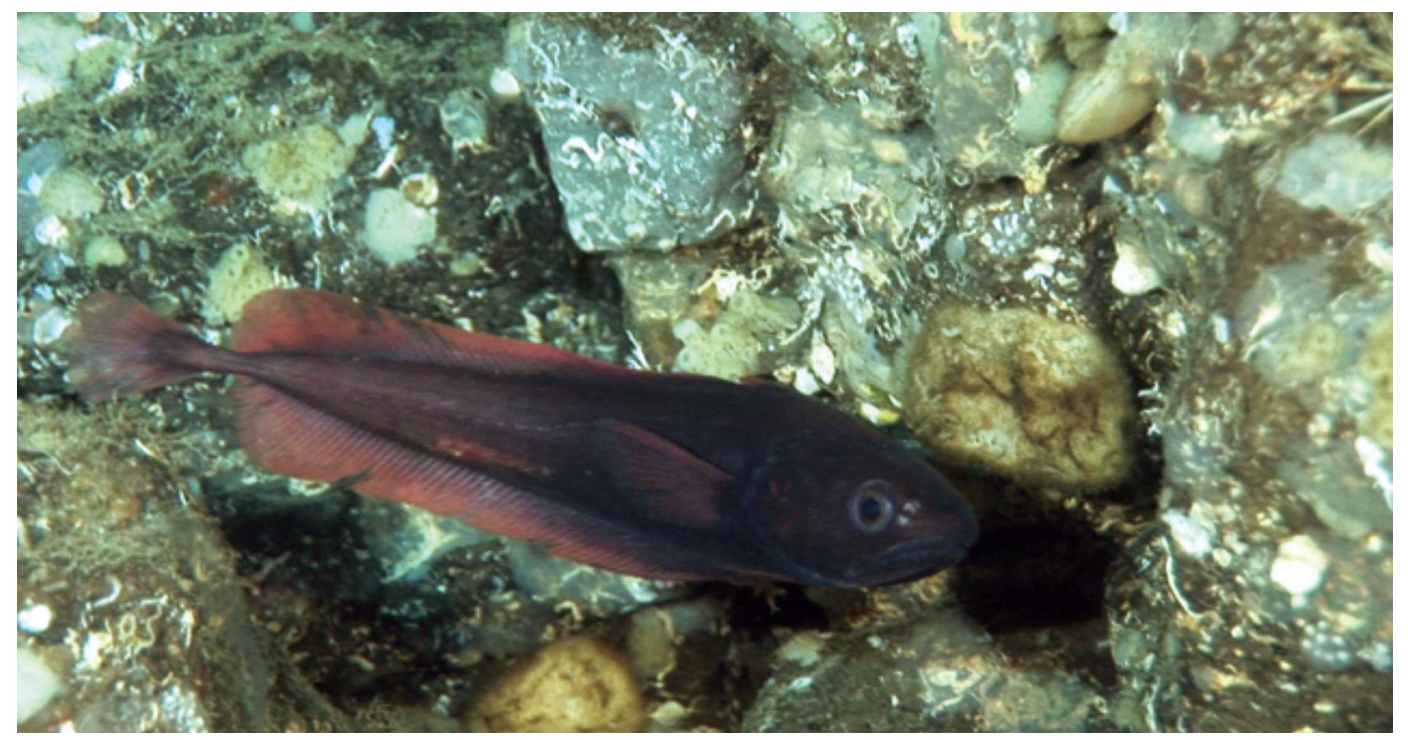

Laemonema cf. gracillipes at Boulders (250 m), 10 May 2009 in the afternoon.

DESCRIPTION: Body elongate, narrowing towards the caudal peduncle, reddish maroon. Fins reddish. Two dorsal fins, the first triangular and short based, the second long based. Mouth terminal and broad. Body diminishes towards caudal peduncle. Depth range: 515-722 m (Meléndez \& Markle, 1997).

WORLDWIDE DISTRIBUTION: Distribution records for Laemonema are between $60^{\circ} \mathrm{N}$ and $40^{\circ} \mathrm{S}$. Laemonema gracillipes is found in Eastern Pacific tropical islands (Meléndez \& Markle, 1997; McCosker \& Rosenblatt, 2010), off the Galápagos Islands and Panama (Meléndez \& Markle, 1997).

Occurrences at Isla del Coco (This study): 150-250 m; Boulders (250 m), afternoon; Piedra 165 (150-170 m), The Edge (200-220 m) and The Wall 475 (220-250 m), in crevices. Difficult to see from the submersible because it hides from the light.

Previous RePorts from Isla del Coco: Laemonema sp. reported by Starr et al. (2012b) at depths greater than $50 \mathrm{~m}$. If Laemonema gracillipes is correct, minimum known depth decreased from 515 m (Meléndez \& Markle, 1997) to $150 \mathrm{~m}$. 
Physiculus sp.

Mora Codling / Mora

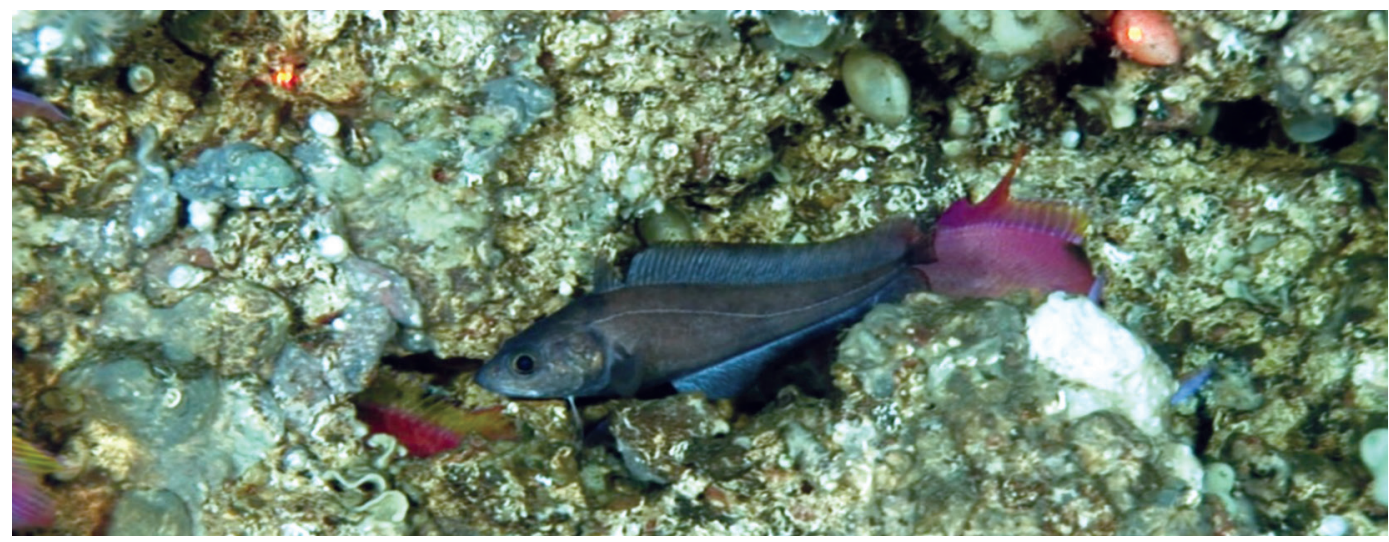

Physiculus sp. at Las Gemelas 1 (250 m), 14, September 2009, morning.

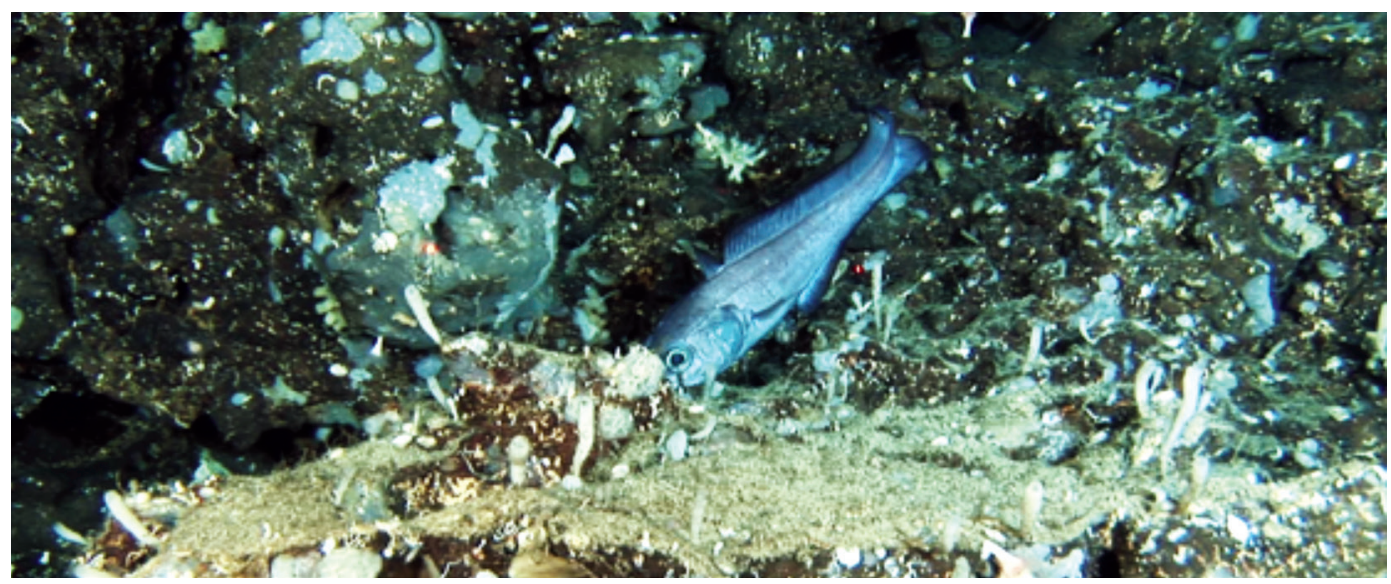

Physiculus sp. at The Wall 475 (304 m), 31 May 2010, afternoon.

Description: Species of the genus Physiculus are caracterized by having a body with a narrow tail base, a chin with a barbell, fins without spines, two dorsal fins and a tail fin separate from dorsal and anal fins (Robertson \& Allen, 2015).

Worldwide Distribution: A circumglobal genus with three endemics species in the Eastern Pacific (Robertson \& Allen, 2015).

Occurrences at Isla del Coco and las gemelas Seamount (This study): 200-304 m, The Edge (200-300 m) and The Wall 475 (200-304 m); Las Gemelas 1 (250 m) and Las Gemelas 3 (205 m).

Previous Reports from Isla Del Coco: Reported by Starr et al. (2012b) at depths greater than $50 \mathrm{~m}$ at Isla del Coco and Las Gemelas Seamount. 


\section{ORDER OPHIDIIFORMES \\ Family Ophidiidae}

Brotula ordwayi Hildebrand \& Barton, 1949

Fore-spotted Brotula / Lengua pintada

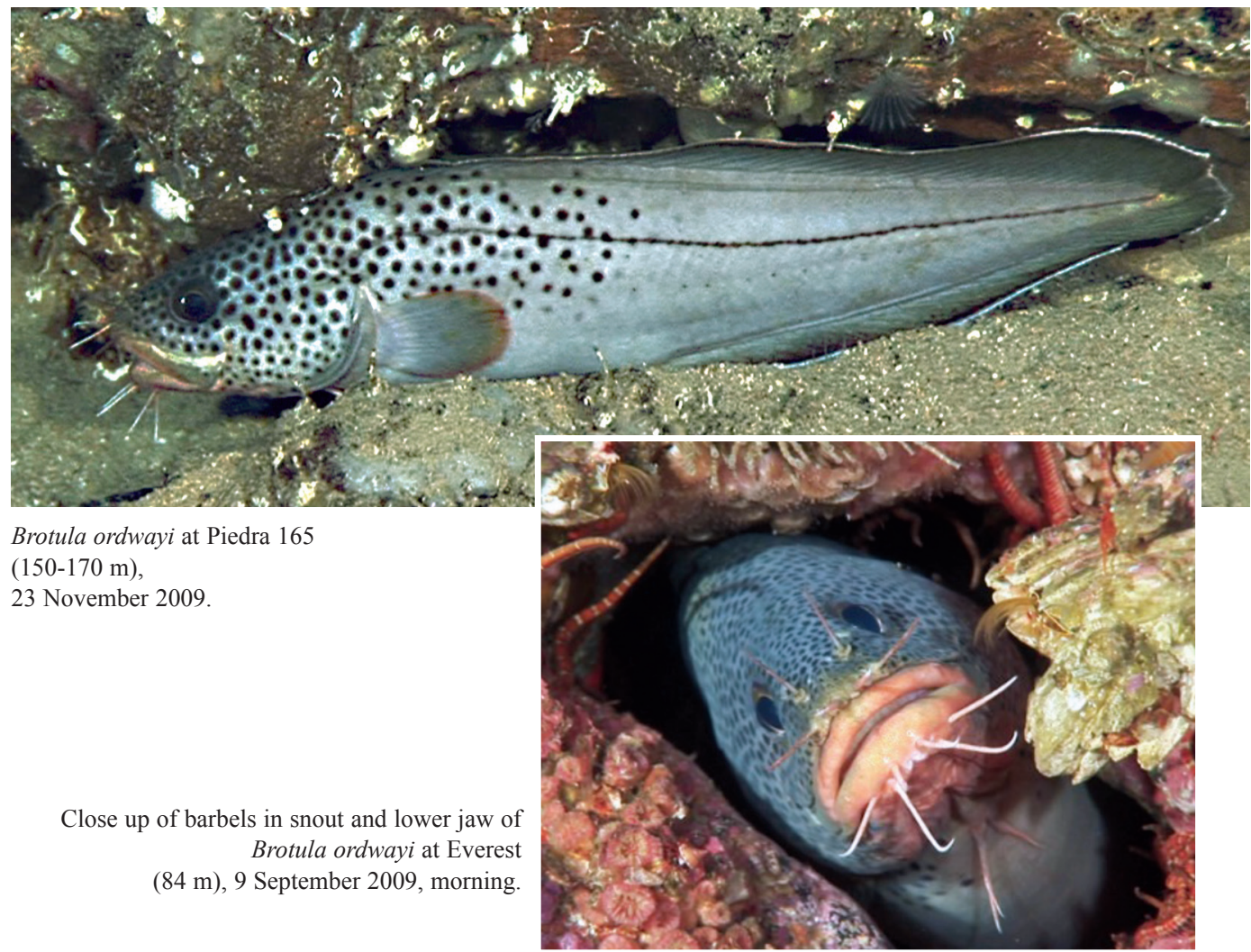

DesCRIPTIOn: Body elongate, compressed. Greyish with blackish spots on head and front part of the body. Dorsal and anal fins with black margin; tail fin continuos with dorsal and anal. Snout and lower jaw with six barbels. Grows to at least $75 \mathrm{~cm}$ and has a depth range of 0-270 $\mathrm{m}$ (Robertson \& Allen, 2015).

Worldwide Distribution: In tropical and subtropical seas (Nielsen, Cohen, Markle, \& Robins, 1999). SE Gulf of California (Robertson \& Allen, 2015) to Perú and the Galápagos Islands (Nielsen et al., 1999; McCosker \& Rosenblatt, 2010) and the Revillagigedo Islands (Robertson \& Allen, 2015).

Occurrences at Isla del Coco (This study): 83-200 m; Everest (83-84 m) and Argo 2 (200 m), morning; Piedra 165 (150-170 m), Kili 2 (180 m) and site close to Piedra Drop (around $200 \mathrm{~m}$ ), morning and afternoon.

Previous Reports From Isla del Coco: Starr et al. (2012b) stated that this species was found at more than $50 \mathrm{~m}$ at Isla del Coco, and see Fourriére et al. (2017). 


\section{ORDER LOPHIIFORMES}

Family Lophiidae

Lophiodes caulinaris (Garman, 1899)

Spottedtail Goosefish / Rape rabo manchado

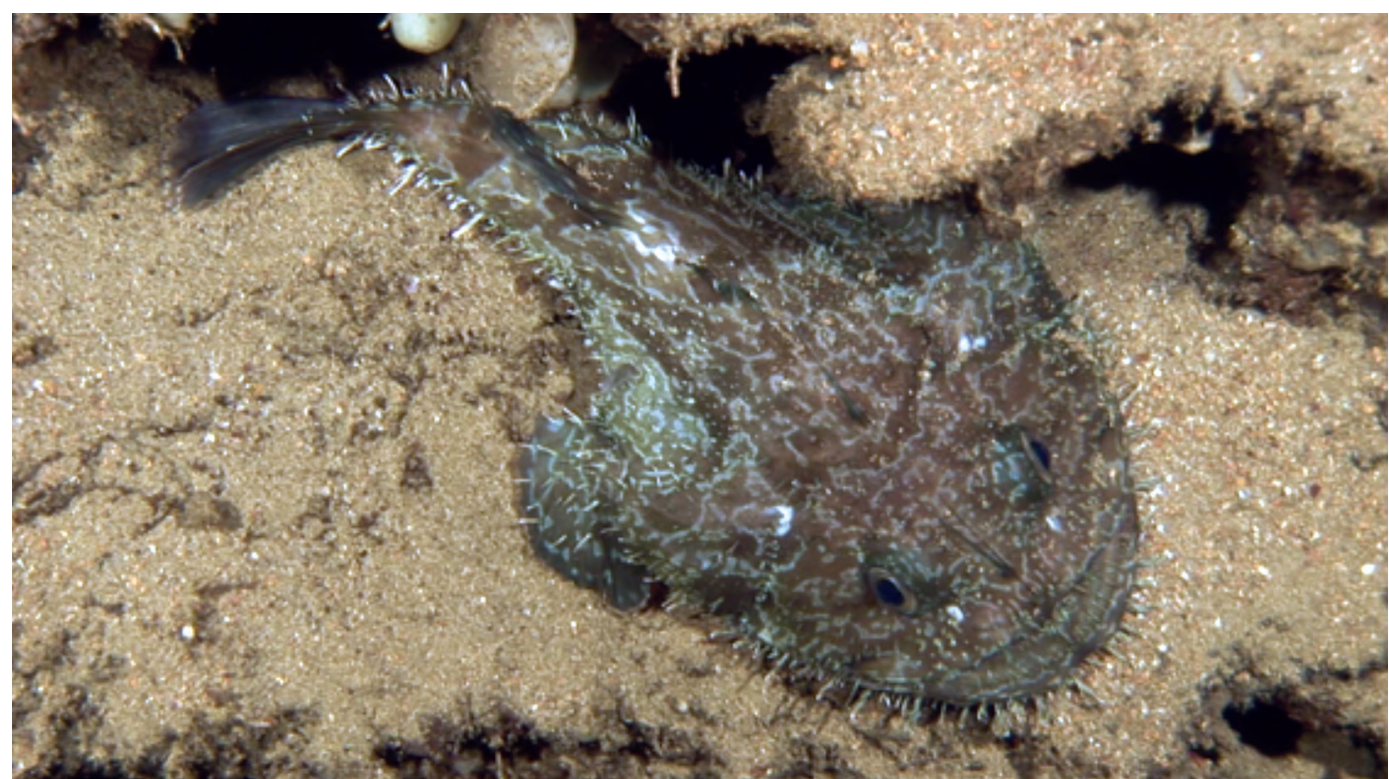

Lophiodes caulinaris at The Wall 475 (230 m), 28 November 2009, afternoon.

DeSCRIPTION: Brown. Head and anterior part of the body depressed, posterior part of de body gradually narrowing. Body with bony spines. First dorsal fin formed by three isolated cephalic spines, the first of which resembles a fishing rod with a complex esca or bait consisting of a pennant-like flap, with long cirri and usually dark, stalked eye-like appendages (Caruso, 1995). Tail dark, very large depressed head and mouth (Bussing \& López, 2005). Pectoral fins limb-like (Robertson \& Allen, 2015), caudal fin has a row of six spots (Caruso, 1995). Size: to about $40 \mathrm{~cm}$. Depth range: 15-311 m (Caruso, 1995).

Worldwide distribution: South California to Perú (López \& Bussing, 1982); Isla del Coco and Malpelo (Robertson \& Allen, 2015).

Occurrences at Isla del Coco (This study): 70-300 m, Everest (70-80 m) and The Wall 475 (230$300 \mathrm{~m})$.

Previous Reports from Isla del Coco: Reported by Bussing \& López (2005), and by Fourriére et al. (2017). 


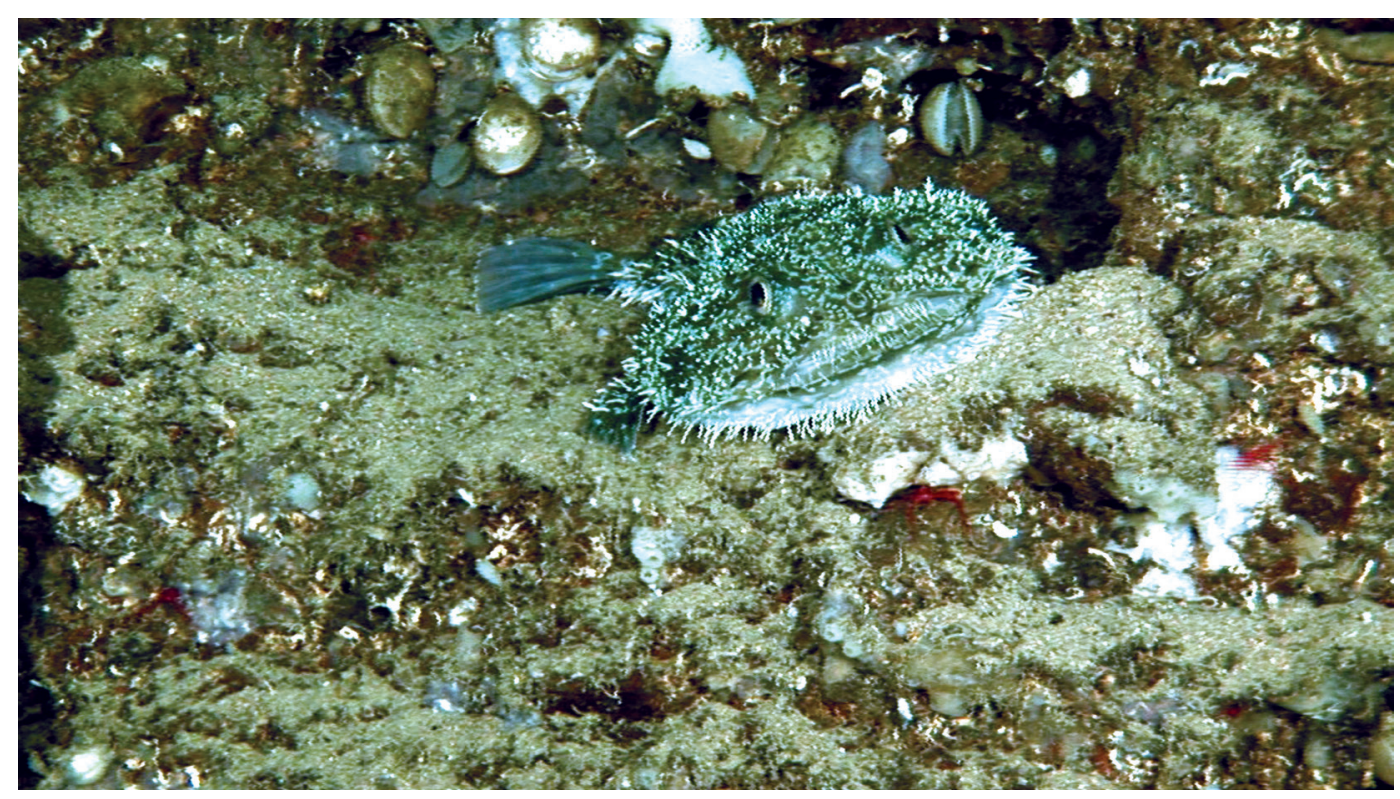

Lophiodes spilurus at The Wall 475 (230 m), 28 Nov 2009, afternoon.

DesCRIPTION: Maroon with turquoise and white lines. Head and anterior part of the body depressed, posterior part of de body gradually narrowing. Body armed with bony spines. First dorsal fin formed by three isolated cephalic spines, the first of which resembles a fishing rod with esca or bait that it's a simple bulb (Caruso, 1995). Tail dark, very large depressed head and mouth (Bussing \& López, 2005). Pectoral fins limb-like (Robertson \& Allen, 2015), caudal fin has a row of six spots (Caruso, 1995). Size: to about $40 \mathrm{~cm}$. Depth range: 15-311 m (Caruso, 1995), 80-850 m (Robertson \& Allen, 2015).

Worldwide distribution: Southern California to Perú (López \& Bussing, 1982); Isla del Coco and Malpelo (Robertson \& Allen, 2015).

Occurrences at Isla del Coco (This study): 200-300 m, The Edge (200-220 m) and The Wall 475 (300 $\mathrm{m})$ up to the slope $(230 \mathrm{~m})$, morning.

Previous Reports from Isla del Coco: Reported by Cortés and Blum (2008), Starr et al. (2012b), and Fourriére et al. (2017). 


\section{Family Antennariidae}

Antennarius commerson (Lacepède, 1798)

Giant Frogfish / Ranisapo gigante

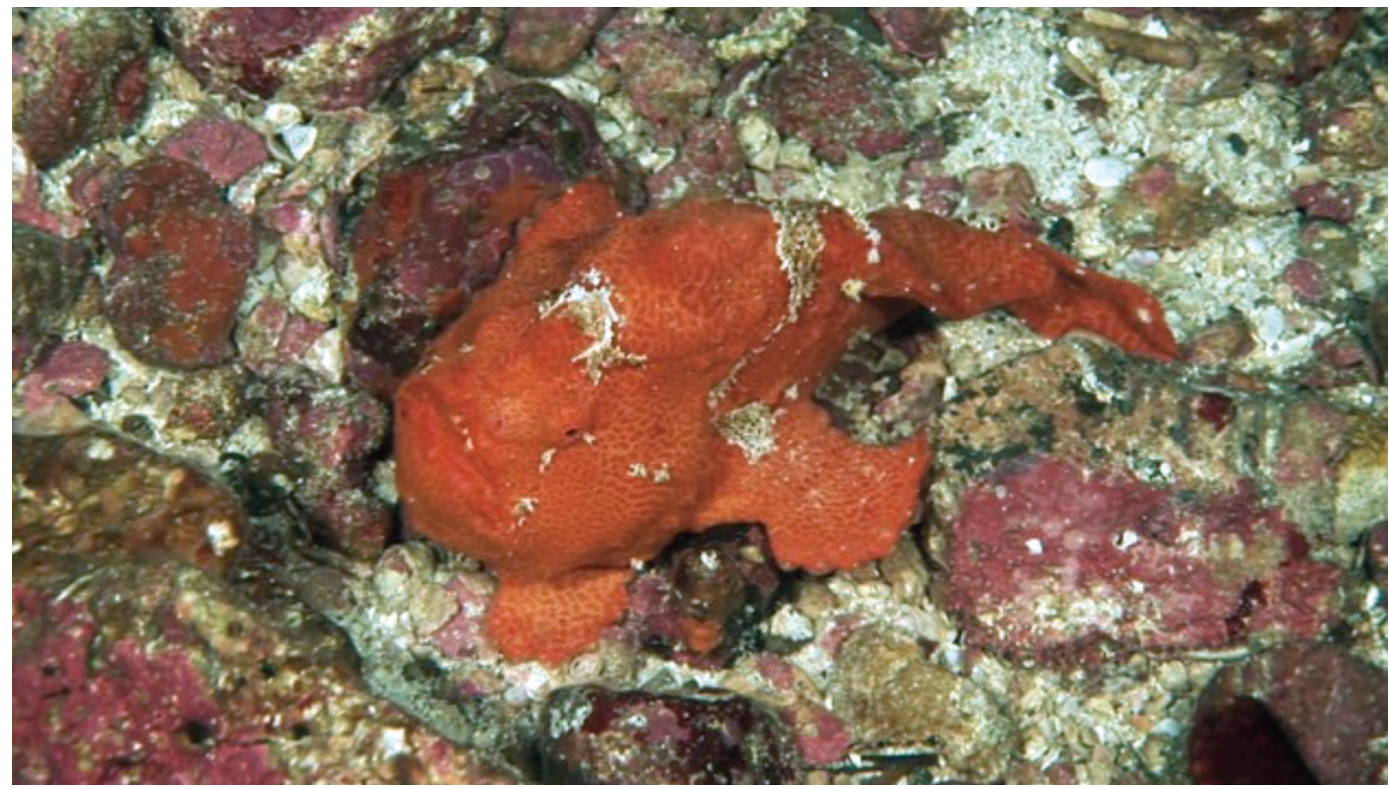

Antennarius commerson at Everest (87 m), 4 April 2007, afternoon.

DESCRIPTION: Body globular; a very large upward directed mouth. Third dorsal spine movable, not bound down by skin, first spine (the esca) modified as a fishing rod. Fleshy pelvic fins leg-like (Schneider \& Lavenberg, 1995). Color variable and skin of body rough (Garrison, 2005). Illicium approximately twice the length of the second dorsal spine; esca branched (Bussing \& López, 2005). Size: $35 \mathrm{~cm}$. Depth range: usually at $20 \mathrm{~m}$ (Schneider \& Lavenberg, 1995), but Myers (1999) records it down to $70 \mathrm{~m}$.

Worldwide distribution: Indo-Pacific (Randall, 2005); Eastern Pacific (Garrison, 2005) from central México to Panamá, and the Revillagigedo, Coco, Malpelo and Gorgona islands (Robertson \& Allen, 2015).

Occurrences at Isla del Coco (This Study): 20-87 m, Bajo Manuelita from $20 \mathrm{~m}$ down to Everest (80-87 $\mathrm{m})$, observed in the afternoon.

Previous RePORTS From Isla Del Coco: Rarely recorded in shallow waters: from Roca Sucia, south side of Isla Manuelita and Isla Pájara (Garrison, 2005), and by Fourriére et al. (2017).

REMARKs: Known maximum depth increases from $70 \mathrm{~m}$ to $87 \mathrm{~m}$. 


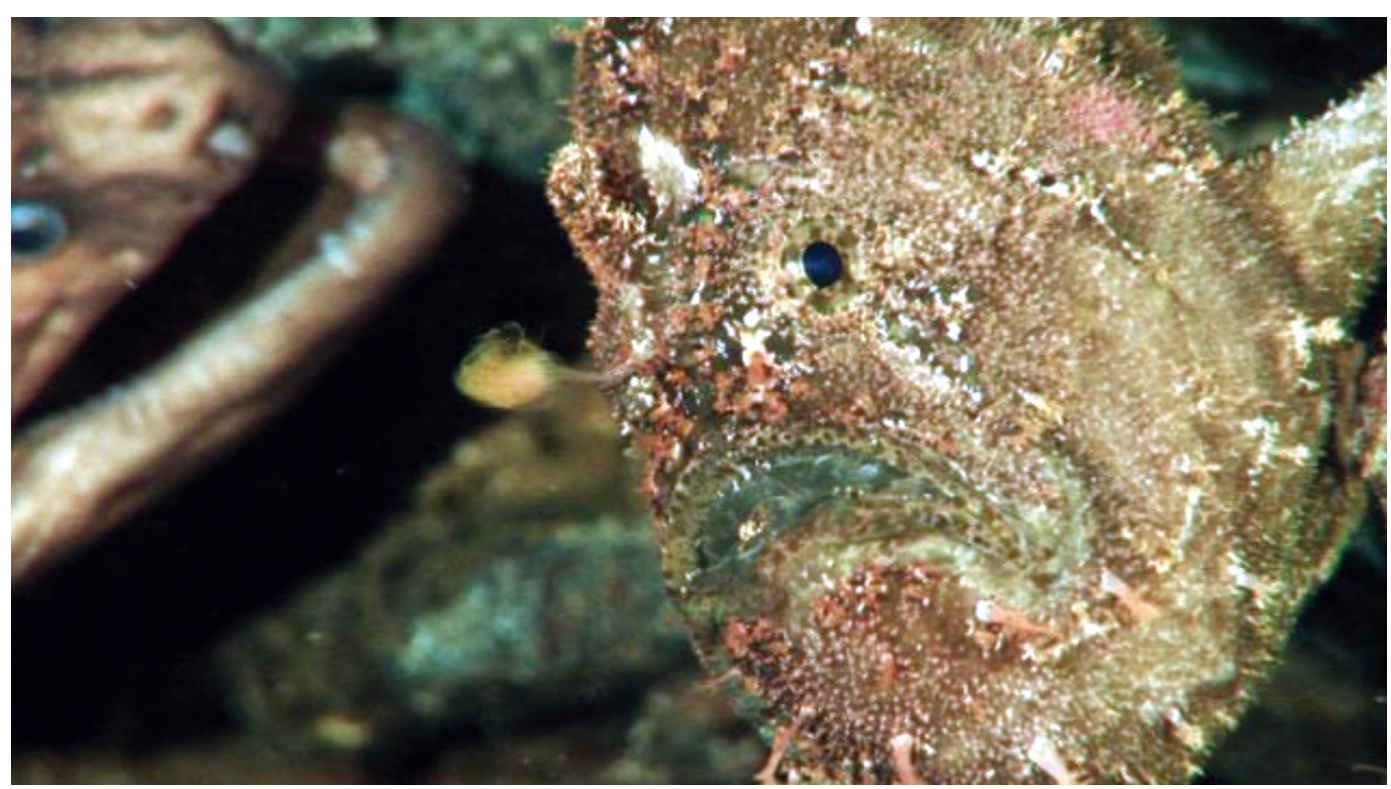

Fowlerichthys avalonis at Piedra 165 (150-160 m), 12 May 2009, afternoon.
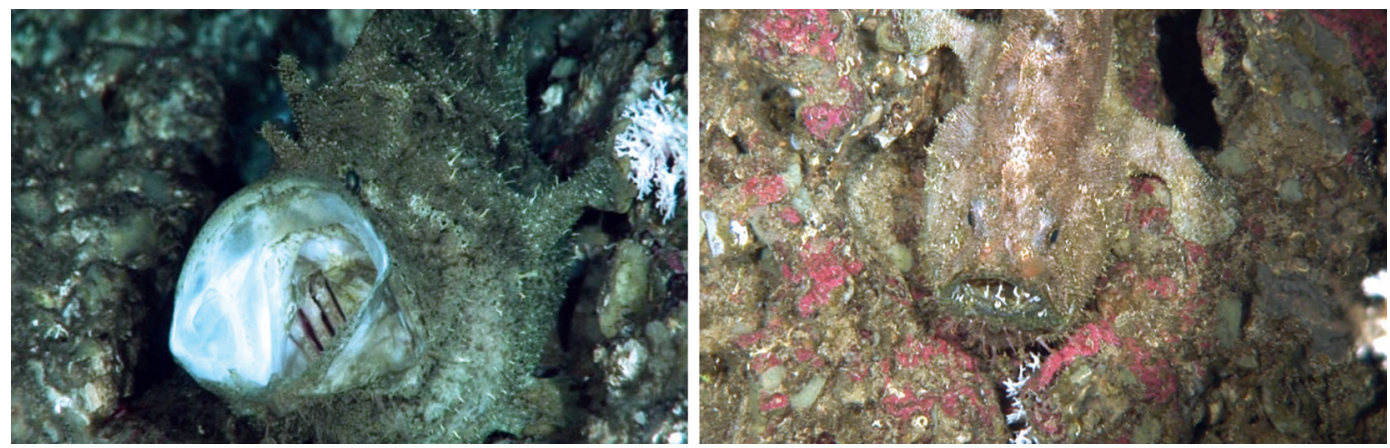

Left, Fowlerichthys avalonis at Piedra 165 (150-160 m), 12 June 2009, afternoon, opening its mouth for feeding. Right, F. avalonis with cryptic coloration at a site near Piedra Drop (200 m), 17 March 2010, afternoon.

Description: Body, head and fins mottled with a network of dark and light brown lines around white spots and a dark irregular bar on the tail fin. Dark blotch at base of last dorsal rays. Upper jaw vertical. First dorsal spine fragmented, second spine modified with a fleshy flap, third dorsal spine not bound. Pectoral fin very thick. Skin of body covered with thick single-pointed spicules; second and third dorsal spines covered with close-set double pointed spicules. Fleshy flaps on lower jaw (Jordan \& Starcks, 1907). Wide range of colors (black, orange, yellow, white, brown) (Robertson \& Allen, 2015). Illicium (first dorsal fin spine) about equal to length of second dorsal 


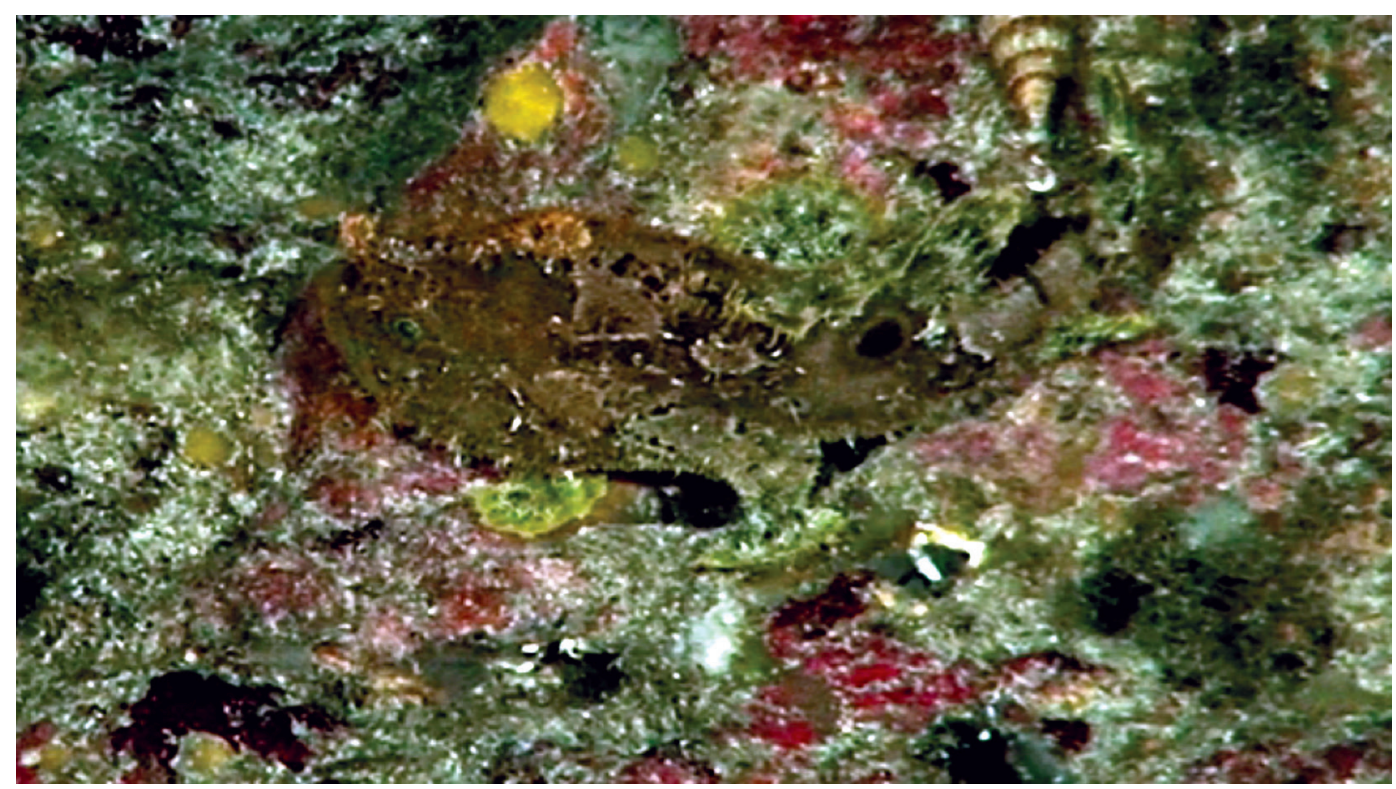

Fowlerichthys avalonis (juvenile frogfish, 5 m) at Piedra 165 (150 m), 11 July 2014.

spine (Schneider \& Lavenberg, 1995), esca, or tip of the illicium, a cluster of appendages (Bussing \& López, 2005) that act as bait. Maximum length: $33 \mathrm{~cm}$. Depth range: from surface to $300 \mathrm{~m}$ (Schneider \& Lavenberg, 1995).

Worldwide Distribution: Eastern Pacific (McCosker \& Rosenblatt, 2010), southern California to the Gulf of California to Perú, Galápagos Islands and Isla del Coco (Robertson \& Allen, 2015).

Occurrences at Isla del Coco (This study): 150-220 m, Piedra 165 (150-170 m), Kili 2 (180 m) and The Edge $(220 \mathrm{~m})$, morning and afternoon.

Previous reports from Isla del Coco: Bussing and López (2005), Starr et al. (2012b) for Isla del Coco as well as for Las Gemelas Seamount, and by Fourriére et al. (2017) at Isla del Coco. 


\section{Family Ogcocephalidae}

Dibranchus sp.

Batfish / Murciélago

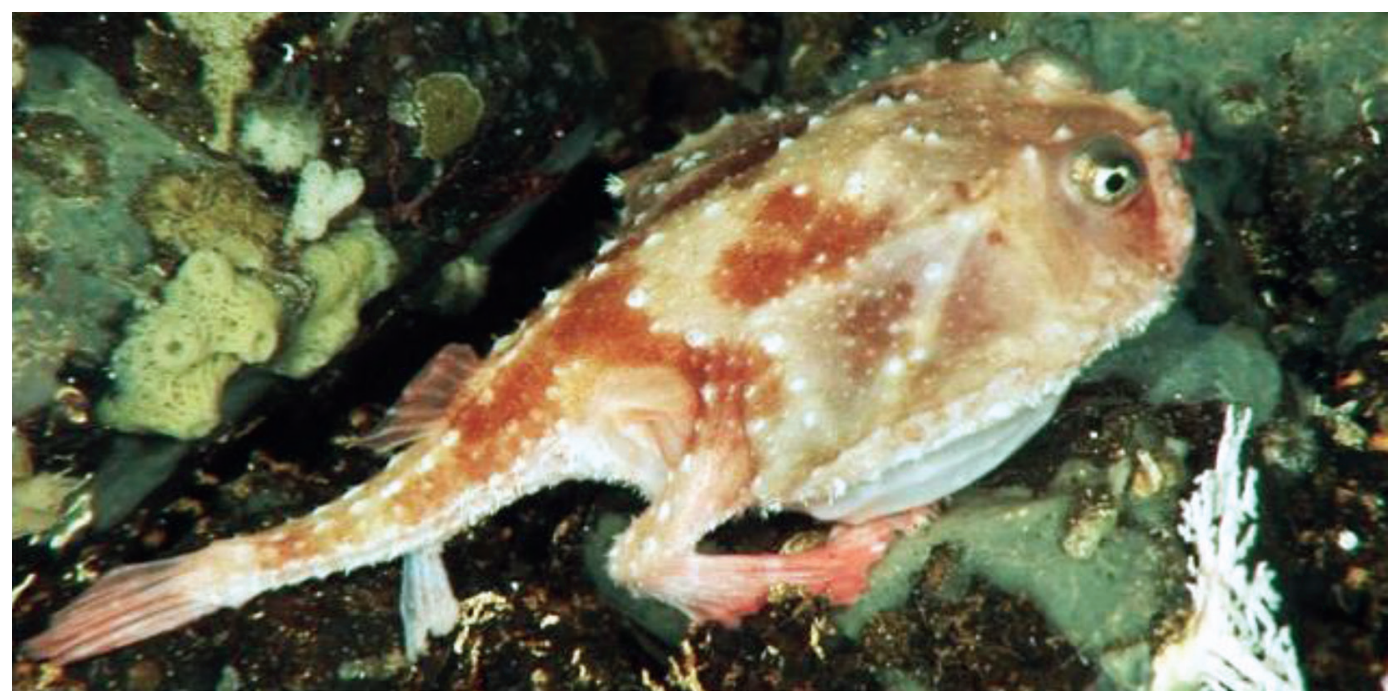

Dibranchus sp. at Las Gemelas 1 (250 m), 14 September 2009, morning.

Dibranchus sp. at

Las Gemelas 1 (250 m), 14 September 2009, morning.

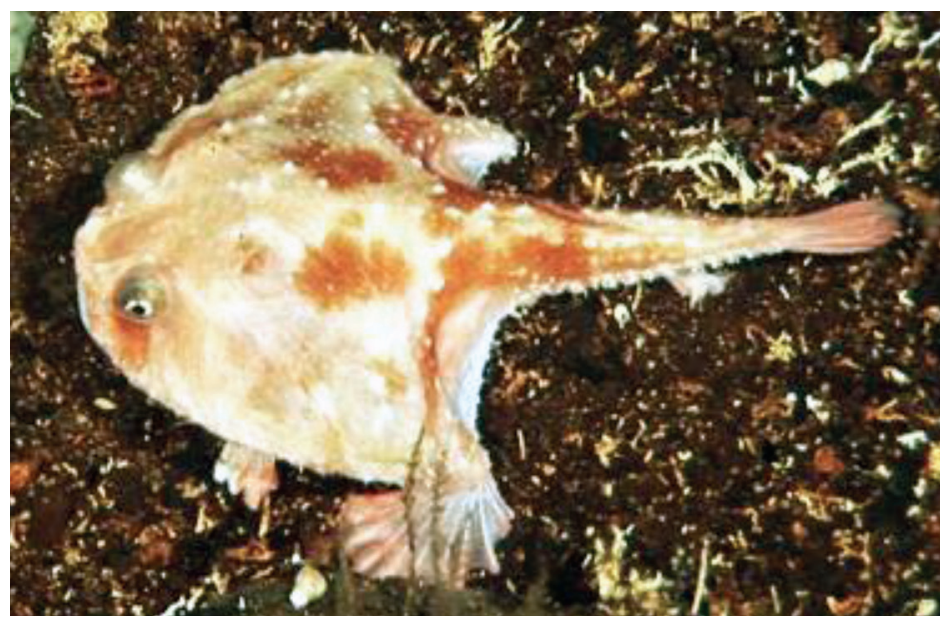

DesCriPtion: Head wide and strongly depressed. Fish-lure between tip of the snout and the mouth (Caruso, 1995). Dorsal surface and dorsal fins salmon-coloured, whitish tubercles. Caudal fin and pectoral fins orange-coloured. Body covered with large tubercles that separate into two longitudinal rows on surface of tail. Pectoral "feet" with smaller tubercles (Bradbury, 1999).

Occurrences at Las Gemelas Seamount (This study): At Las Gemelas 1 (250 m), morning.

REMARKS: Identification of this species remains tentative until capture of organisms for detail examination. Dibranchus cracens was reported by Starr et al. (2012b) at Las Gemelas at more than $50 \mathrm{~m}$ deep. 


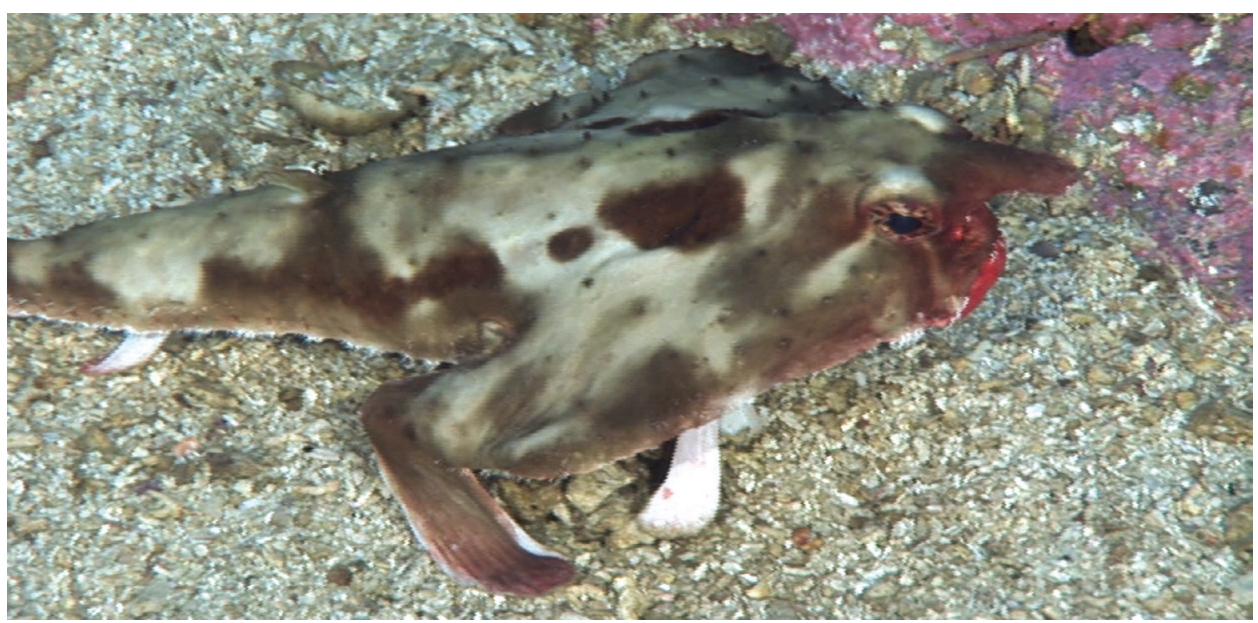

Ogcocephalus porrectus at Everest (89 m), 11 December 2007, morning.

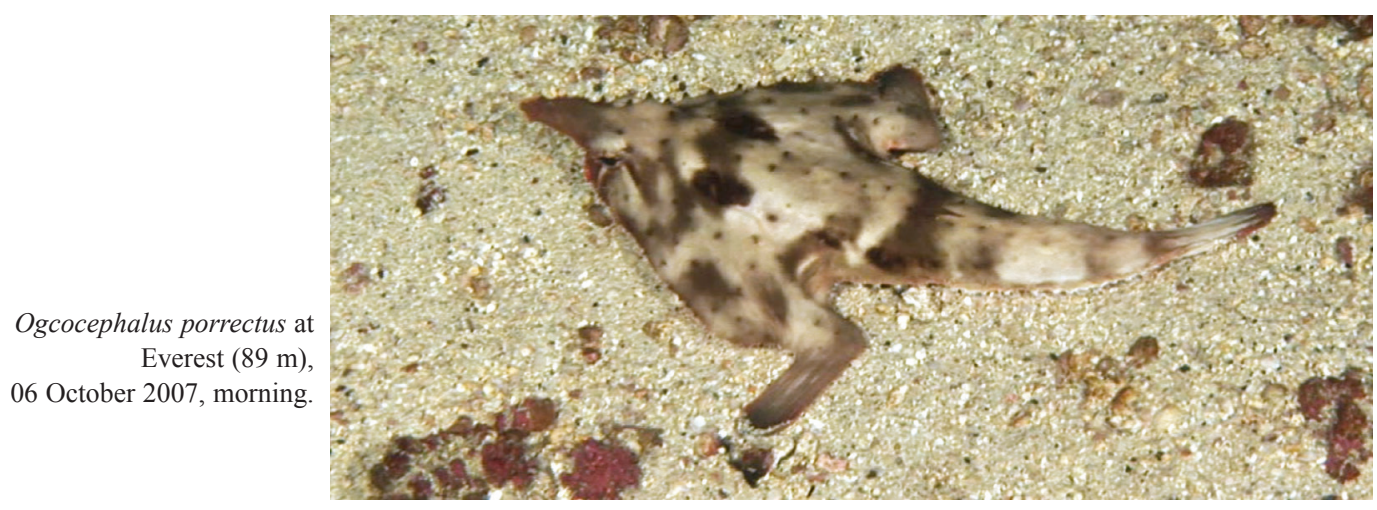

DeSCRIPTION: Disc and caudal region subtriangular, flattened at the inner surface. Skin rough with prominent spiny buckles. Each side of the body with a longitudinal dark brown stripe starting at the head and going all the way to the tail. Brownish on dorsal surface, orange-red along ventral surface, pelvic and anal fins on ventral region mostly white (Bradbury, 1980). Mouth red (Garrison, 2005) with horn-like rostrum. Fish-lure in a small cavity under horn. Size: $16 \mathrm{~cm}$ (Robertson \& Allen, 2015). Depth: 35-150 m (Bradbury, 1980; Robertson \& Allen, 2015).

Worldwide Distribution: Isla del Coco (Bussing \& López, 2005; Garrison, 2005) and probably Malpelo, although that population could belong to an undescribed species (Robertson \& Allen, 2015).

Occurrences at Isla del Coco (This study): From $30 \mathrm{~m}$ descending to Everest, down to $150 \mathrm{~m}$ near Piedra 165. Everest (85-90 m), morning; Bajo Manuelita $(62-65 \mathrm{~m})$, morning and afternoon.

Previous Reports from Isla del Coco: Reported in shallow waters at Isla del Coco (Bussing \& López, 2005; Garrison, 2005): Ulloa, Bajo Manuelita and Roca Sucia (Garrison, 2005), and by Fourriére et al. (2017). 


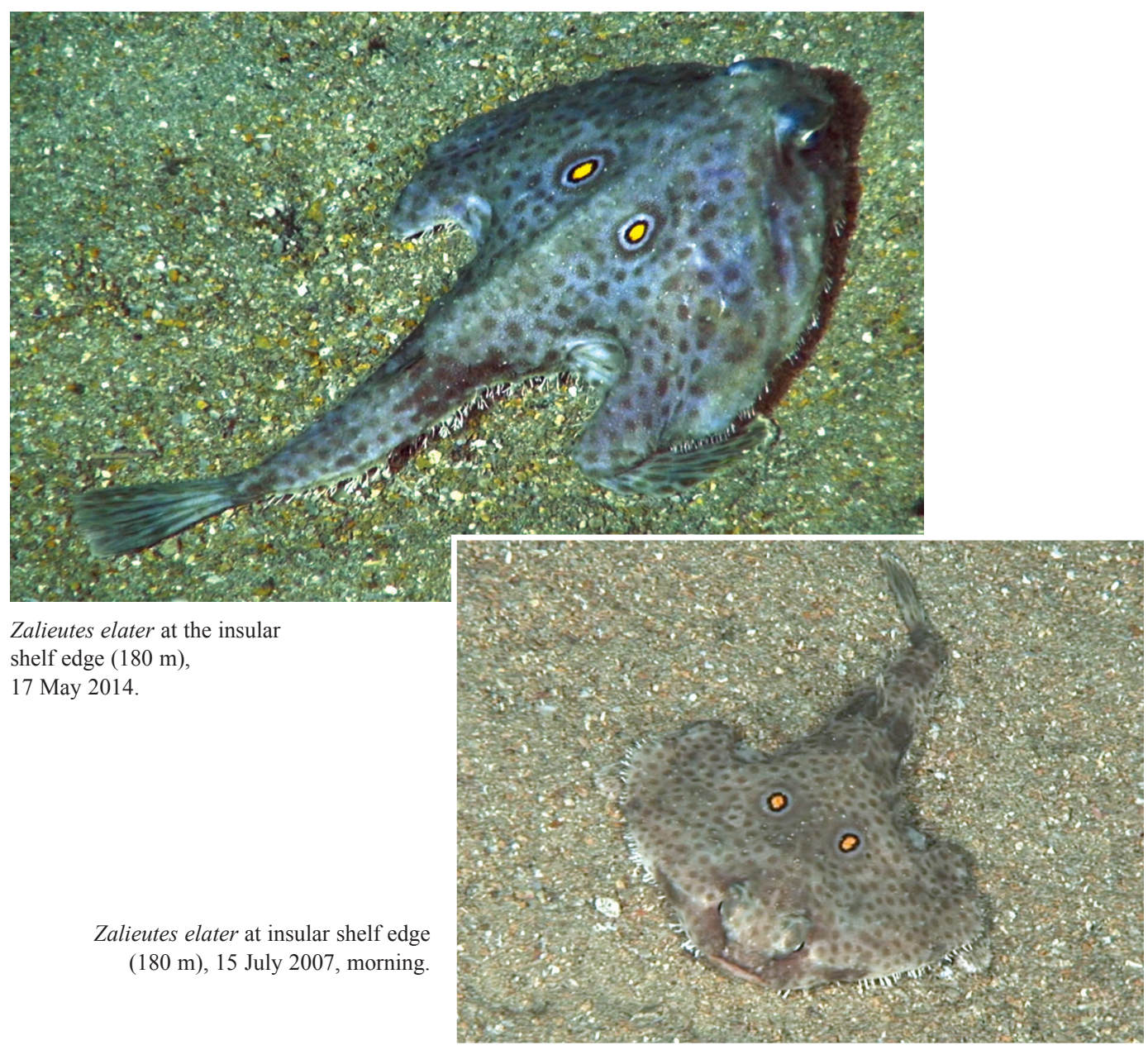

DESCRIPTION: Brown with many darker irregular brown spots. A pair of black-rimmed dorsal yellow ocelli. Head and body much depressed, together forming a broad subtriangular disc. Ilicium protractile, esca large. Skin covered with fine closely placed sharp striate-based tubercular scales, among with larger scattered tubercles. Arm-like pectoral fin. "Fishing pole" in small cavity under snout (Robertson \& Allen, 2015). Size: up to $15 \mathrm{~cm}$. Depth: 20-160 m (Robertson \& Allen, 2015), maximum depth reported for Costa Rican waters: 329 m (Angulo-Sibaja, 2014).

Occurrences at Isla del Coco (This Study): 80-200 m, Everest (80 m), insular shelf edge on the north side of the island (180 m), Kili 2 (180 m) and The Edge $(200 \mathrm{~m})$.

Worldwide Distribution: California to Perú, and Isla del Coco (Robertson \& Allen, 2015).

Previous Reports from Isla del Coco: Reported at Isla del Coco by Bussing and López (2005), also on sandy bottoms between 160-180 m by Cortés and Blum (2008), and by Fourriére et al. (2017). 


\section{ORDER GASTEROSTEIFORMES \\ Family Aulostomidae \\ Aulostomus chinensis (Linnaeus, 1766) \\ Chinese Trumpetfish / Trompeta china}

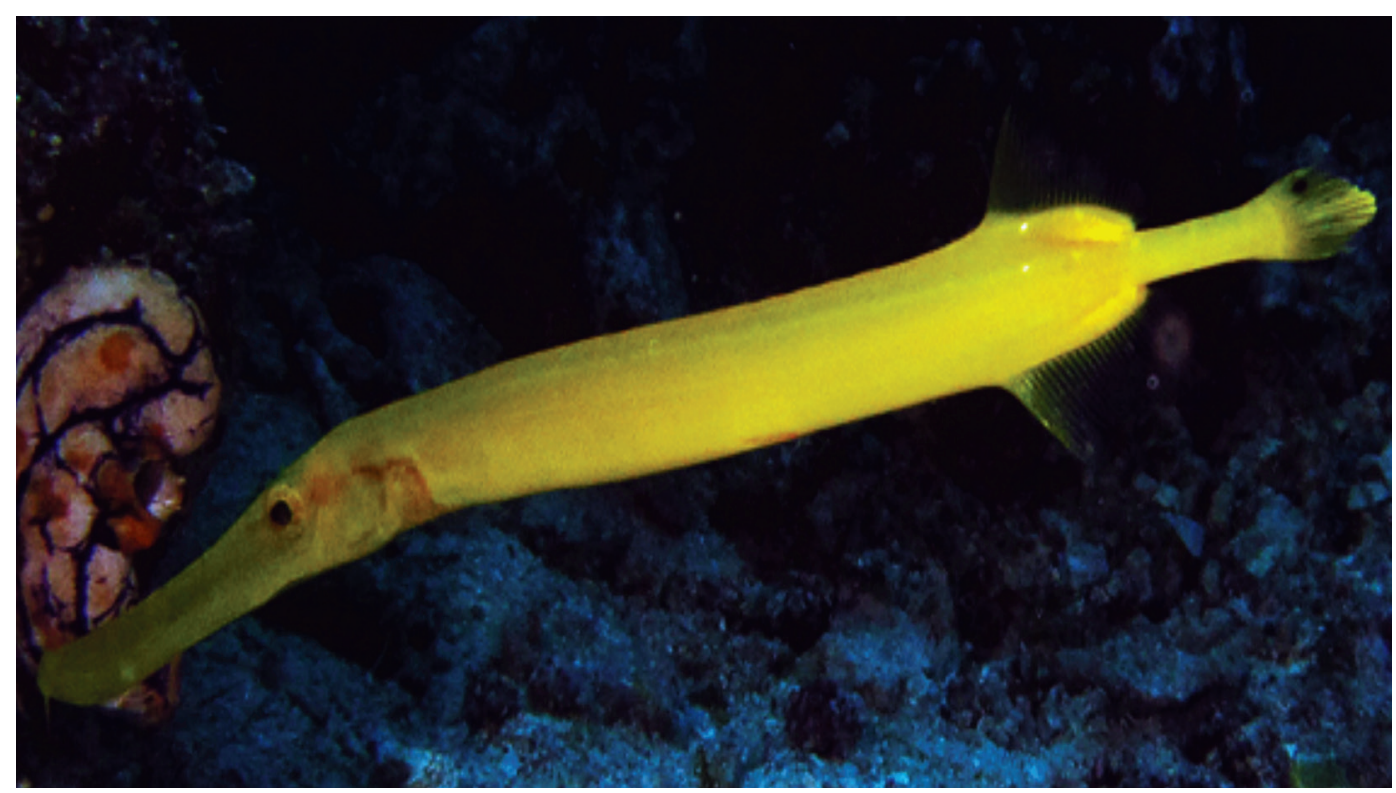

Aulostomus chinensis at Everest (60 m), 28 April 2009, afternoon.

DesCRIPTION: Long slender compressed body encased in bony plates (Fritzsche, 1995) usually brown with pale bars; some individuals are completely bright yellow (Bussing \& López, 2005) but are less common (Garrison, 2005). Long tubular snout, lateral line continuous. Size: 75 cm (Fritzsche, 1995). Depth: to 122 m (Myers, 1999).

Worldwide Distribution: Indo-Pacific, and Eastern Tropical Pacific from Panamá to Ecuador, in the tip of Baja California and all the oceanic islands (Robertson \& Allen, 2015).

Occurrences at Isla del Coco (This Study): 45-60 m; Bajo Manuelita (50-60 m), afternoon; Everest (45-60 m), morning and afternoon.

PREVIOUS REPORTS FROM IsLA DEL COCO: Common in shallow waters (Bussing \& López, 2005; Garrison, 2005), and by Fourriére et al. (2017) as a deep-water species. 


\section{ORDER SCORPAENIFORMES \\ Family Scorpaenidae \\ Pontinus clemensi Fitch, 1955}

Spotted Scorpionfish / Rascacio moteado

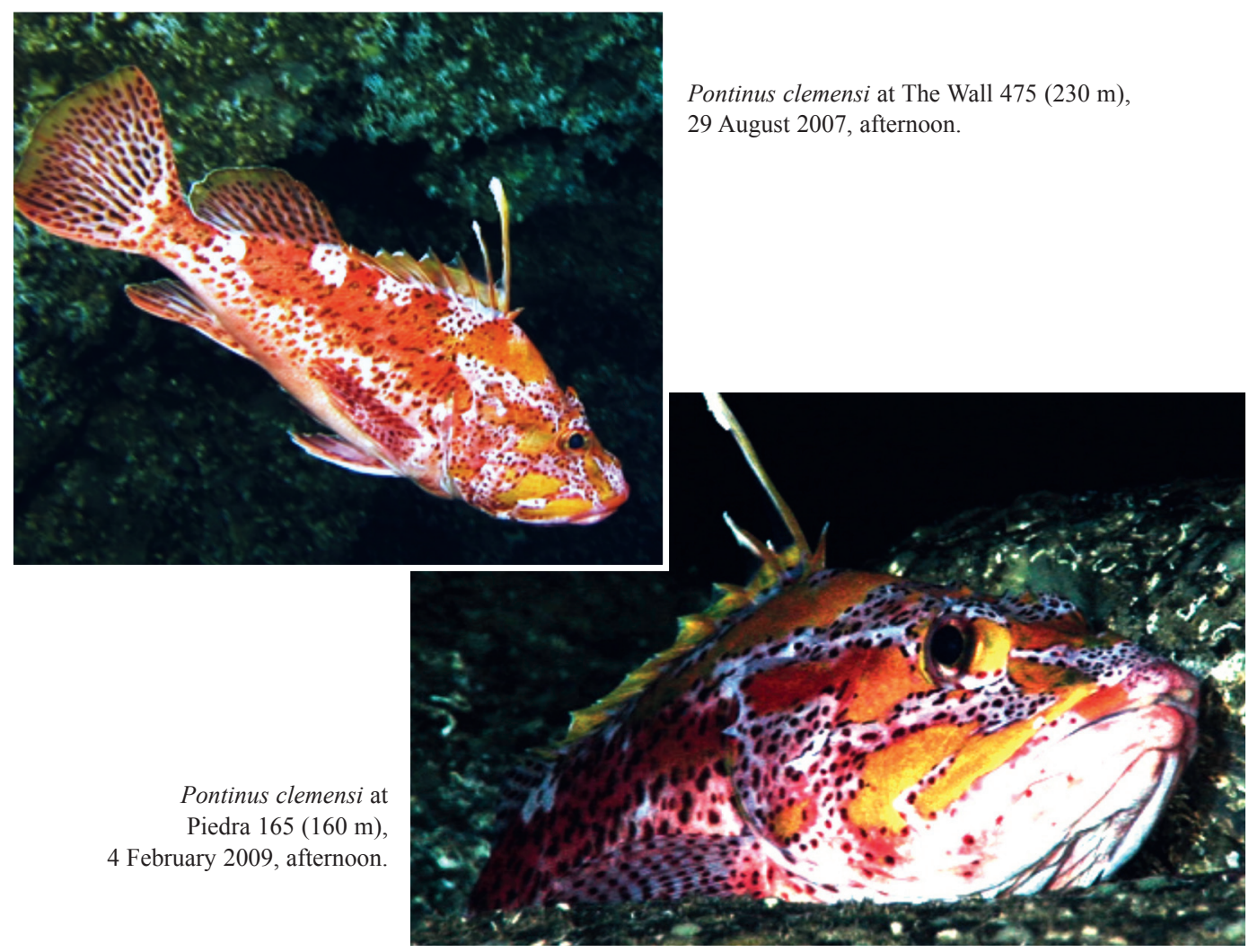

DESCRIPTION: Head and body compressed, pink color. Large eyes; body with irregular dark reddish spots (Poss, 1995) forming bars on caudal fin. Second and third dorsal fin spines elongated, of equal length (Bussing \& López, 2005). Size: $56 \mathrm{~cm}$ (Robertson \& Allen, 2015). Depth: 50-250 m (Robertson \& Allen, 2015); Mora, Jiménez, and Zapata (2000) collected individuals at more than $90 \mathrm{~m}$; Aburto-Oropeza et al. (2010) reported the species at $250 \mathrm{~m}$.

Worldwide distribution: Eastern Pacific (McCosker \& Rosenblatt, 2010; Robertson \& Allen, 2015). Colombia (Franke \& Acero, 1996), northern Perú (Chirichigno, 1978), Islas Galápagos (McCosker et al., 1997), Isla Malpelo (Mora et al., 2000), Isla del Coco (Bussing \& López, 2005) and the Gulf of California (Aburto-Oropeza et al., 2010).

Occurrences at Isla del Coco (This study): 150-230 m, Piedra 165 (150-170 m), Kili (170 m), near Kili 2 (180 m), Argo 2 (180-205 m), The Edge (200-220 m), Kili Rock (220 m), The Wall 475 $(215-230 \mathrm{~m})$ and Banana $(225 \mathrm{~m})$. Species observed morning and afternoon.

Previous Reports from Isla del Coco: Bussing and López (2005), in deep waters at more than 50 $\mathrm{m}$ by Starr et al. (2012b), and by Fourriére et al. (2017). 
Pontinus sp. A

Scorpionfish / Pez escorpión

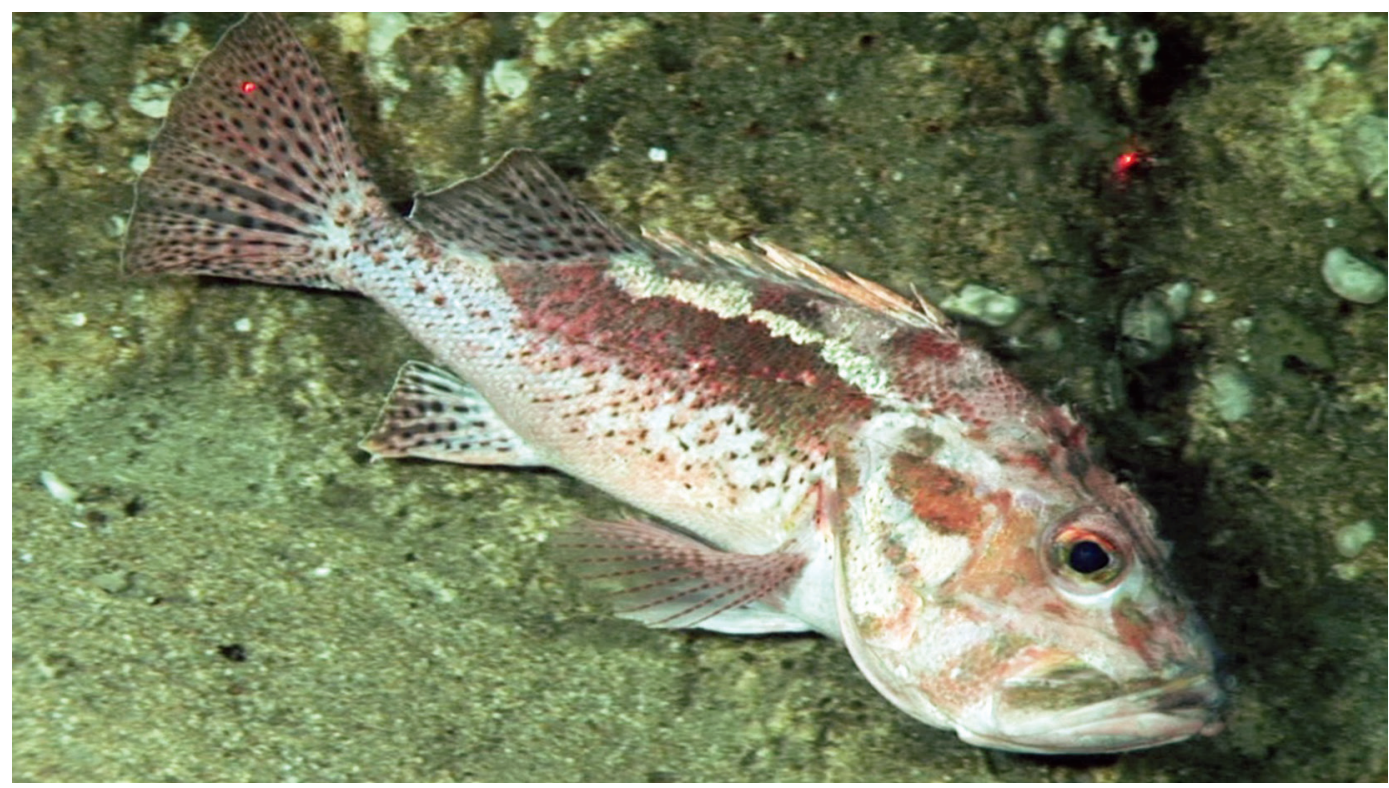

Pontinus sp. A at The Wall 475 (250 m), 12 September 2009, morning.

Laser beams are $33 \mathrm{~cm}$ apart.

DesCriPTIOn: Representatives of Pontinus have compressed pinkish bodies and heads. Eyes large; body with irregular dark reddish spots (Poss, 1995). Second and third dorsal spine elongate or equal length depending on the species (Bussing \& López, 2005). This individual shows a D-III spine of intermediate length if compared with Pontinus clemensi, snout larger than diameter of eyes.

Occurrences at Isla del Coco (This study): The Wall 475 (220-320 m), morning.

Previous Reports From Isla del Coco: In addition to the records of $P$. clemensi already mentioned (Bussing \& López, 2005, Starr et al., 2012b), P. strigatus and P. furcirhinus have also been reported for Isla del Coco (Bussing \& López, 2005; Robertson \& Allen, 2015). Starr et al. (2012b) reported two species of Pontinus as P. furcirhinus? and P. strigatus?

Remarks: The photographed individual, which has the snout longer than the eye, is not $P$. strigatus as this species is characterized as having a snout shorter than the diameter of the eye (Robertson \& Allen, 2015). This species is unlikely to be P. strigatus as it has a much longer snout and pattern of coloration over the dorsum, but not the ventrum, is quite distinct from that seen in [the holotype of] P. strigatus (Stuart Poss, personal communication 2017). 


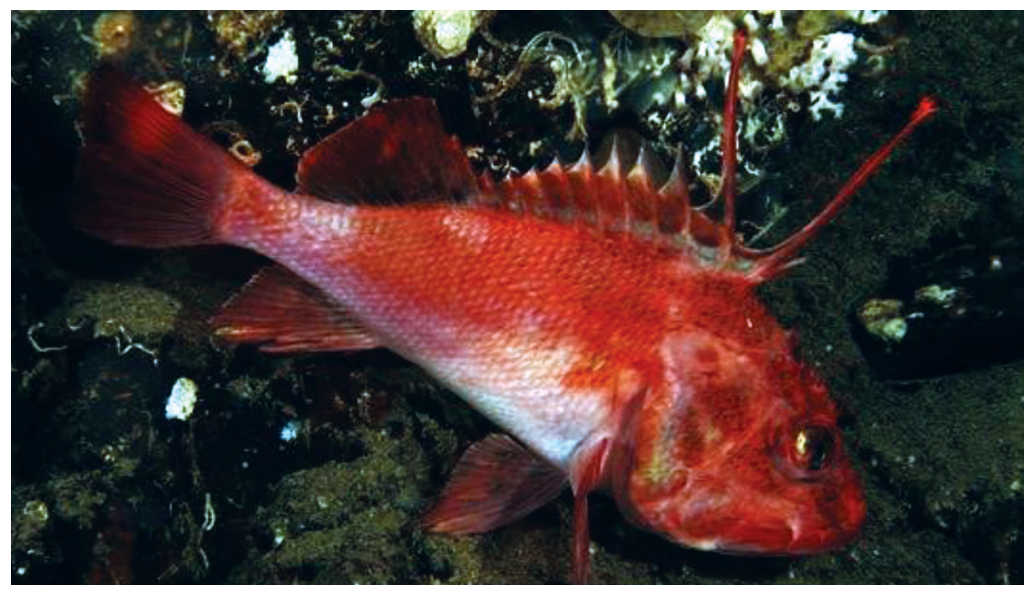

Pontinus sp. B at The Wall 475 (270 m), 28 September 2009 , afternoon.

DESCRIPTION: Head very bony; with numerous spines, lateral line complete. The genus is characterized by having 15-20 pectoral rays, all unbranched (Poss, 1995). The second and third dorsal spines are elongate or equal length, depending on the species (Bussing \& López, 2005). The individuals photographed for this publication are red with greenish blotches and a paler underbody. Also, the second and third dorsal spines appear elongate and broadened at the tip. Dorsal and anal fins have a white margin.

Occurrences at Isla del Coco and at Las Gemelas seaMOUNT (THIS STUDY): 180-400 m; Kili 2 (180 m), morning; Las Gemelas 3 (205 m), The Wall 475 (215-400 m) and

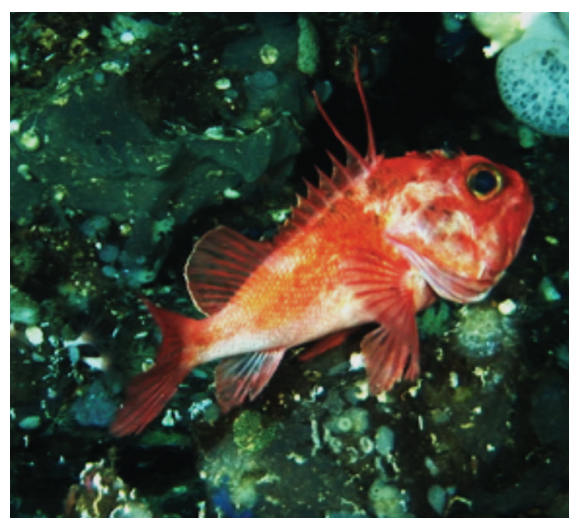

Pontinus sp. B at The Wall 475 (309 m), 10 February 2010, afternoon. Las Gemelas $1(250 \mathrm{~m})$, afternoon.

Previous Reports from Isla del Coco: In addition to the mentioned registers of $P$. clemensi (Bussing \& López, 2005; Starr et al., 2012b), P. strigatus and P. furcirhinus have also been reported for Isla del Coco (Bussing \& López, 2005; Robertson \& Allen, 2015). Starr et al. (2012b) reported two species of Pontinus as P. furcirhinus? and P. strigatus?

Remarks: Of the species of Pontinus present in the Eastern Tropical Pacific, only P. clemensi (which was described above as having characteristics that do not match the photographs of Pontinus sp. B) and P. vaughani have the second and third dorsal spines elongate. However, P. vaughani has a dark pink body with dense blotches, often dotted with striking colors such as yellow and blue. In addition, it is restricted to Baja California, the southeastern part of the Gulf of California and the Revillagigedo and Clipperton islands. In Pontinus strigatus the third dorsal spine is much longer than the second, which is not the case with this individual. The photographs shown here do not match any of the named members of the genus found in the eastern Pacific. 


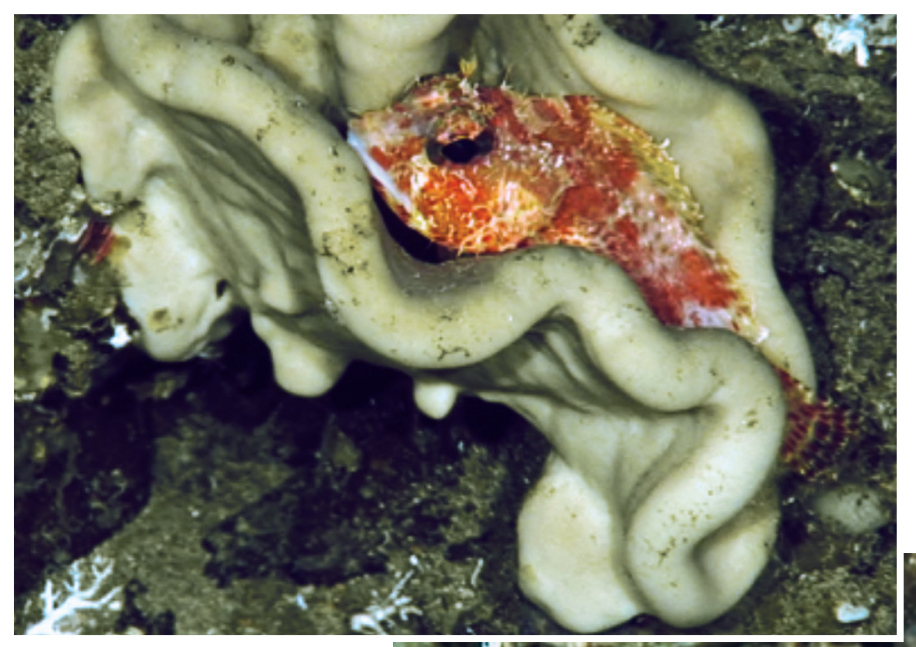

Pontinus sp. C on a sponge at Piedra 165 (160 m), 29 November 2009, morning.

\begin{abstract}
Pontinus sp. C at The Edge (200 m), 29 November 2009,
\end{abstract} morning.

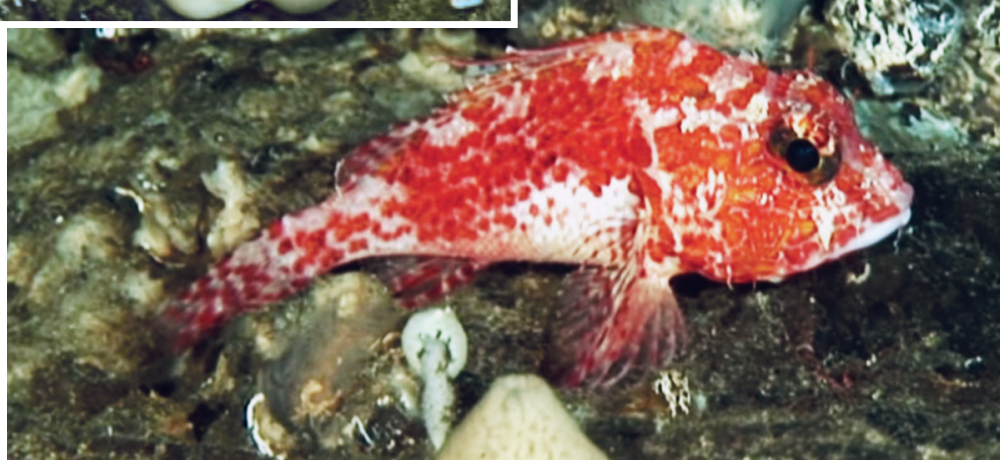

Description: Head very bony; with numerous spines, lateral line complete. The genus is characterized by having 15-20 pectoral rays, all unbranched (Poss, 1995). The second and third dorsal spines are elongate or equal length, depending on the species (Bussing \& López, 2005). Some of the photographed individuals shown in this paper have an elongate third dorsal spine. Also, in some cases, it is possible to see a stalked branched tentacle over the eye and D membranes yellow, as in P. strigatus.

Occurrences at Isla del Coco and at Las Gemelas Seamount (This study): 150-220 m, Piedra 165 (150-170 m), Kili (170 m), Kili 2 (170 m), Argo 2 (200 m), Las Gemelas 2 (200 m), The Edge (200 $\mathrm{m})$ and The Wall $0475(215-220 \mathrm{~m})$, morning and afternoon.

Previous RePORTS FROM Isla del Coco: In addition to the afore mentioned records of $P$. clemensi (Bussing \& López, 2005; Starr et al., 2012b), P. strigatus (Bussing \& López, 2005) and P. furcirhinus (Robertson \& Allen, 2015) have also been reported for Isla del Coco. Starr et al. (2012b) reported two species of Pontinus as P. furcirhinus? and P. strigatus?

REMARKS: Identification of this species remains tentative until captured of organisms for detail examination. In case the species is P. furcirhinus (50-390 m), which extends from the Gulf of California to Peru (Robertson \& Allen; 2015) the known depth range will not change. 

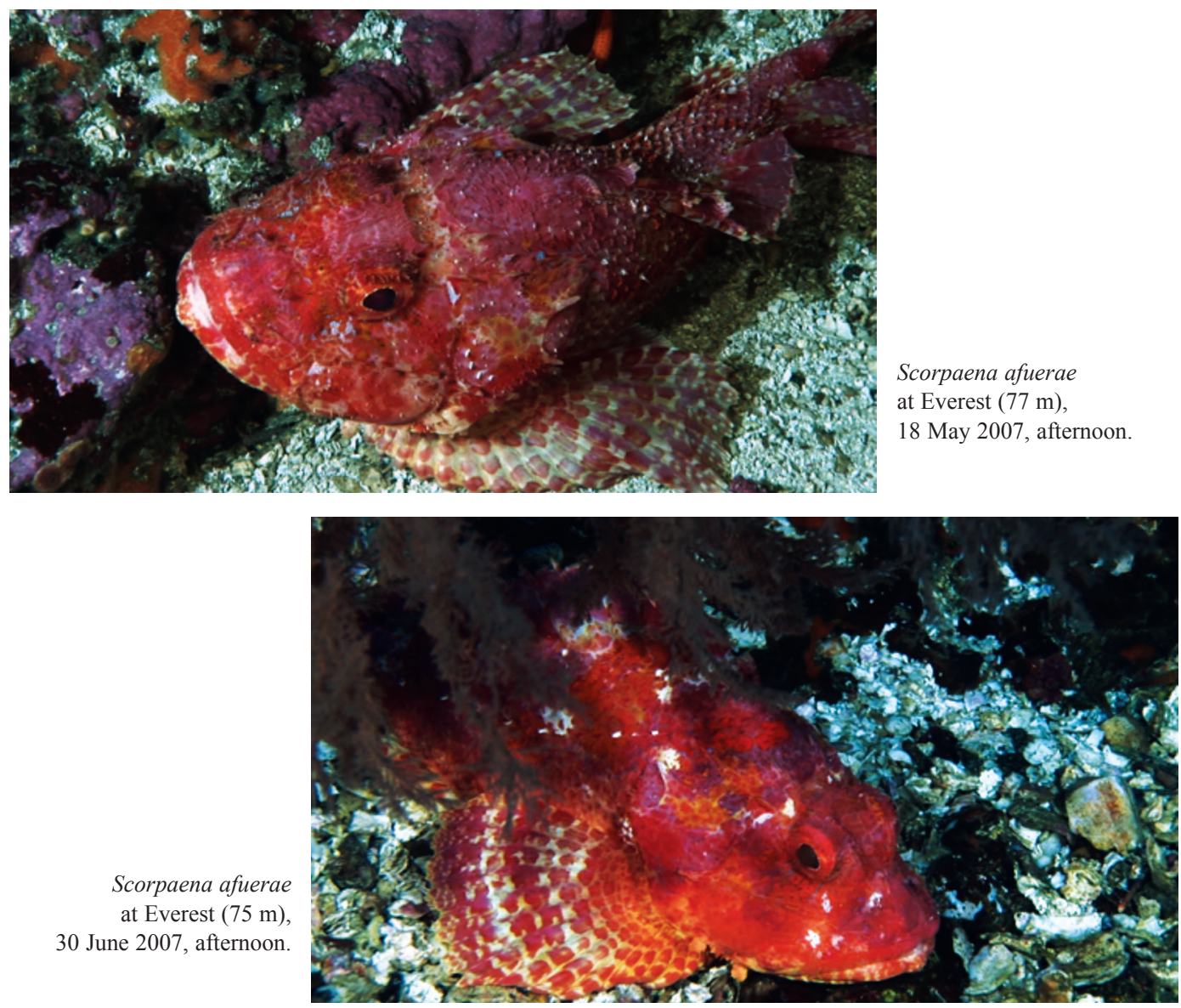

DeSCRIPTION: Body, head and fins scarlet to orange brown, with striations and discrete red mottling and spotting. Irregular red barring on fins, except spiny dorsal which is all red. Dorsal fin with 12 spines and 9 soft rays. Head large, with spines above the eyes (three or four). Lower jaw without tentacles (Poss, 1995). Horizontal bony ridge below eye smooth (Bussing \& López, 2005). Maximum length: $35 \mathrm{~cm}$. Depth: 35 to 100 m (Jiménez-Prado \& Béarez, 2004, Robertson \& Allen, 2015).

Worldwide Distribution: The tip of Baja California to Ecuador and Perú and Isla del Coco (Jiménez-Prado \& Béarez, 2004; Robertson \& Allen, 2015).

Occurrences at Isla del Coco (This study): 60-90 m, Bajo Manuelita (60 m) and Everest (60-90 $\mathrm{m})$, morning and afternoon.

Previous Reports from Isla del Coco: Reported at Isla del Coco by Bussing and López (2005). Starr et al. (2012b) indicate the possible presence of this species at Las Gemelas at more than 50 $\mathrm{m}$; however, they also point out that there is doubt with the identification and thus recorded it as Scorpaena sp. Also reported by Fourriére et al. (2017) as a deep-water species. 
Scorpaenodes rubrivinctus Poss, McCosker \& Baldwin, 2010

Red-banded Scorpionfish / Rascacio de barras rojas
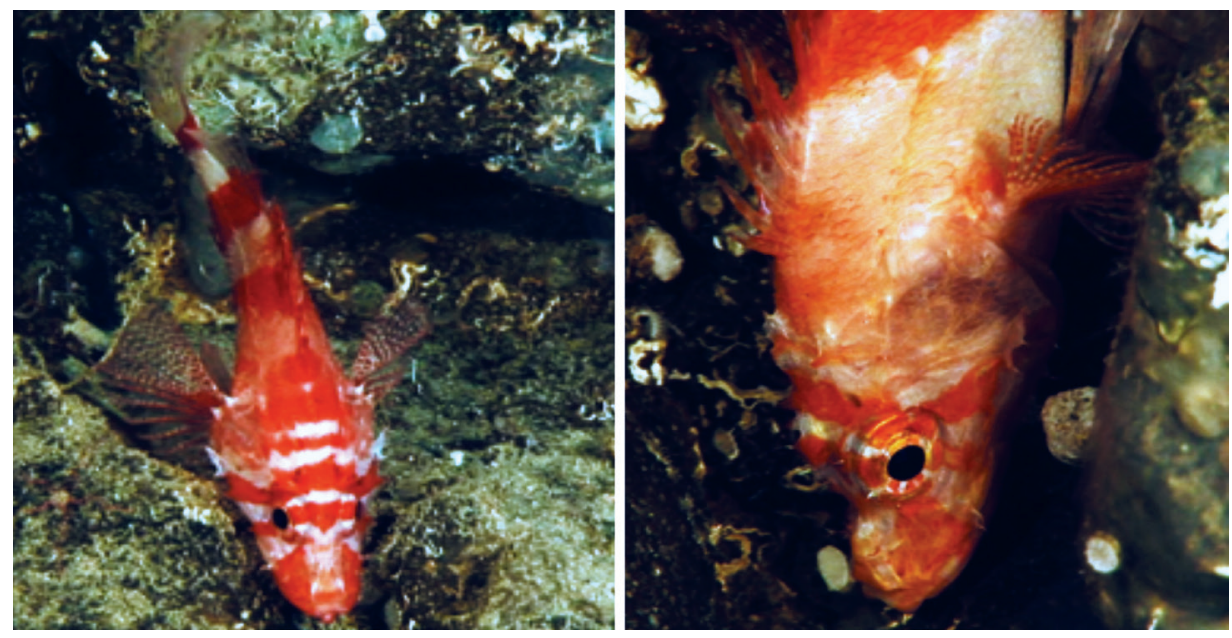

Scorpaenodes rubrivinctus at Piedra 165 (150 m), 23 June 2009, afternoon.

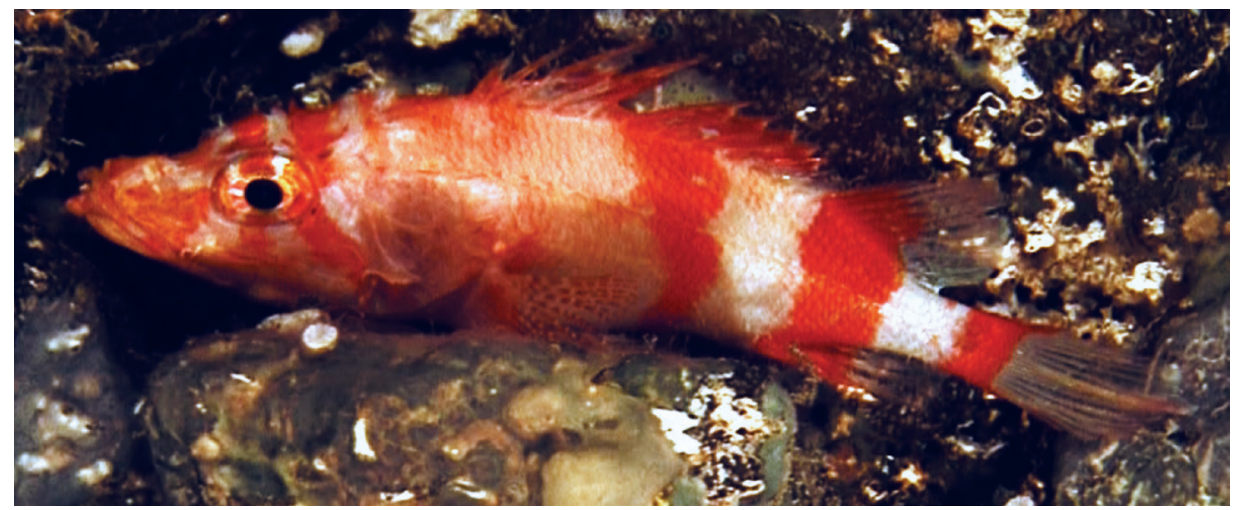

Scorpaenodes rubrivinctus, at Piedra 165 (150 m), 23 June 2009, afternoon.

DesCRIPTION: Head and body pink grading to white on rear of body and tail base. Body with three broad and distinct red bars from top to bottom, the firt at level of center of spiny dorsal fin, second at level of soft dorsal fin and the last one in the tail base and base of tail fin. Head also with red bars. Pectoral fin with 18-20 rays. Dorsal spines elongate. Snout long, suborbital ridge with spines extending laterally to form a crest with suborbital spines. Depth range 160-412 m, more abundant at 260-290 m; often in association with sponges (Poss et al., 2010).

Worldwide Distribution: Eastern Pacific at Islas Galápagos and Isla del Coco (Poss et al., 2010).

Occurrences at Isla del Coco and Las Gemelas Seamount (This study): 150-230 m; Las Gemelas $3(170 \mathrm{~m})$ and The Wall 475 (210-230 m), afternoon; Piedra 165 (150-170 m), morning and afternoon.

Previous RePORTS From Isla Del Coco: Recorded previously for Isla del Coco by Poss et al. (2010) at a depth range of 160-300 m with the submersible DeepSee, and by Fourriére et al. (2017). 
Scorpaenidae, unidentified sp.

Scorpionfish / Pez escorpión

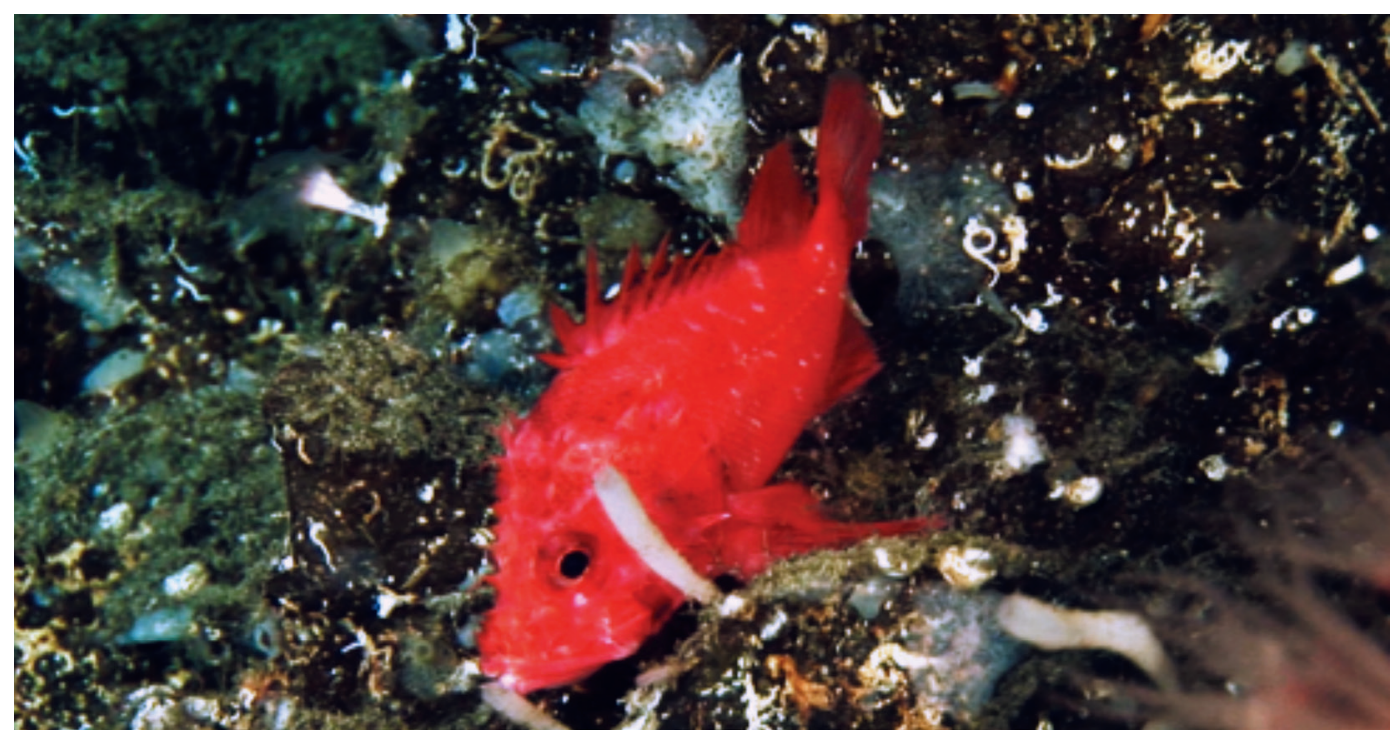

Scorpaenidae, unidentified at Piedra 165 (170 m), 22 March 2007, afternoon.

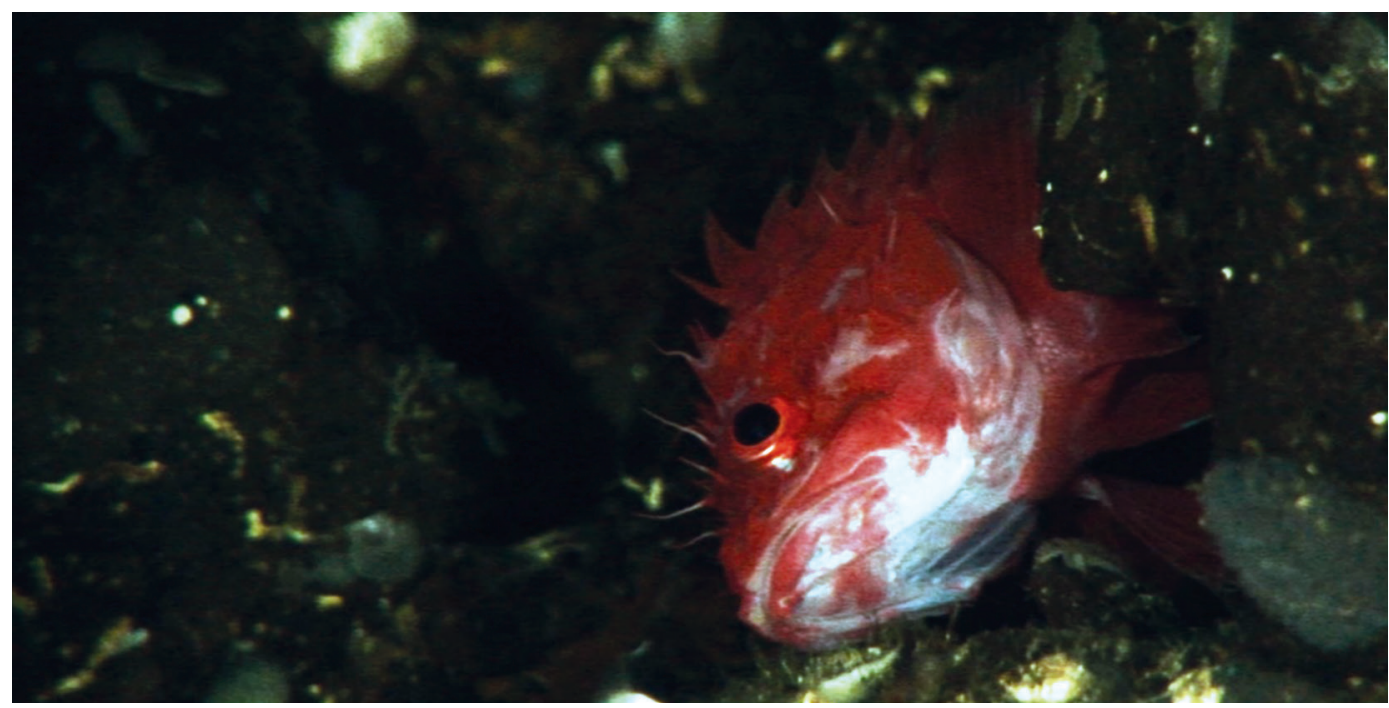

Scorpaenidae, unidentified at Piedra 165 (170 m), 11 September 2009, afternoon.

DESCRIPTION: Head and body reddish, with dark spots on the head.

Occurrences at Isla del Coco (This study): Piedra 165 (150-170 m). 


\section{Family Triglidae}

Bellator sp.

Searobin / Vaca o rubio

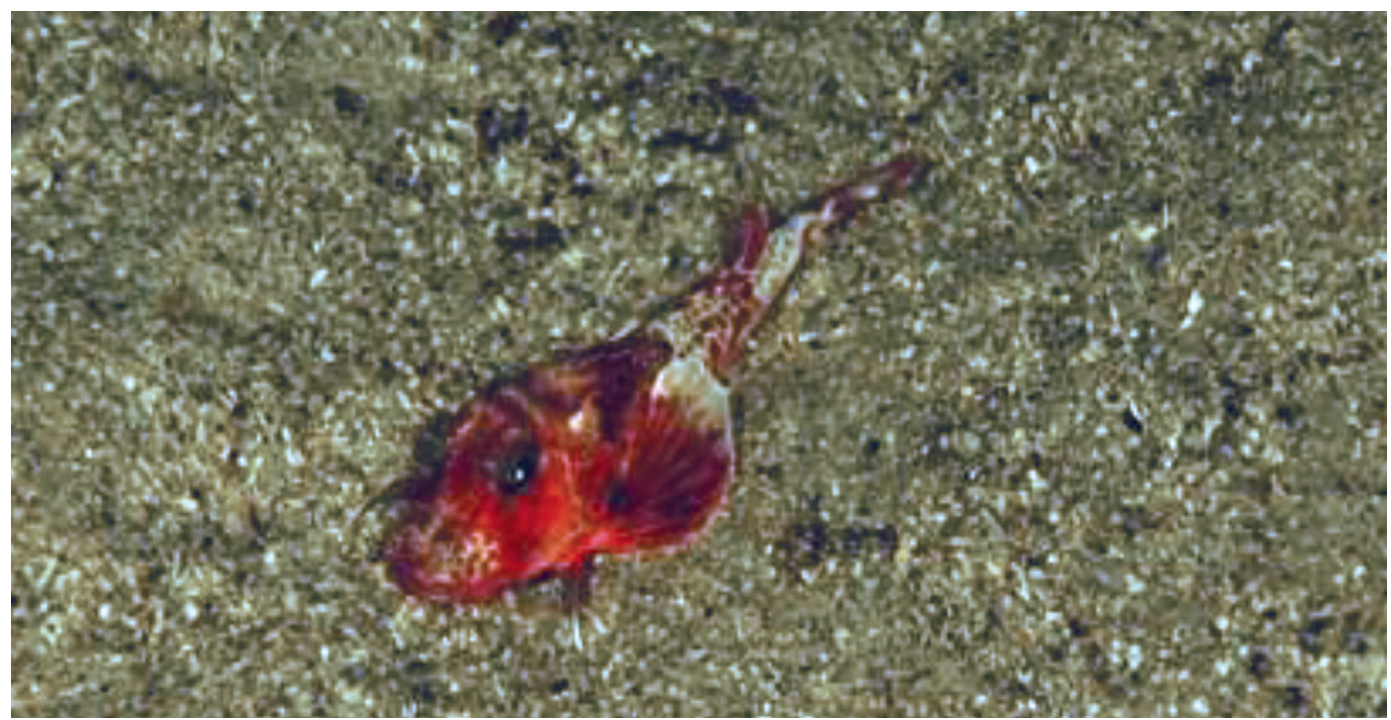

Bellator sp. at Arena (110 m), 16 September 2009, afternoon.

DESCRIPTION: Triglids are characterized for having an armoured and spiny head. The genus Bellator consists of fishes with a body with rough scales and a large, squarish and bony head that has many ridges and spines and are narrow between eyes (Robertson \& Allen, 2015). Pectoral fins short, with 12 joined rays reaching origin of anal fin, and with 3 enlarged, free rays detached from main fin (Robertson \& Allen, 2015).

WorLDWIDE DISTRIBUTION: A neotropical to subtropical genus. Four species are known to be endemic to the Eastern Tropical Pacific.

Occurrences at Isla del Coco (This study): Arena at $110 \mathrm{~m}$.

Previous RePorts From Isla del Coco: Bellator farrago is known from the Galápagos and Isla del Coco, B. loxias is known from southern Baja to Peru and the Revillagigedos and Isla del Coco, and B. gymnostethus and B. xenisma are known from mainland waters from Baja California to Ecuador or Perú (Richards \& McCosker, 1998, Robertson \& Allen, 2015).

REMARKS: In addition to the four known species occurring in the Eastern Tropical Pacific, a fifth species from Isla del Coco remains undescribed (Robertson \& Allen, 2015). 


\section{Family Peristediidae}

Peristedion nesium Bussing, 2010

Insular Armoured-searobin / Cabro isleño

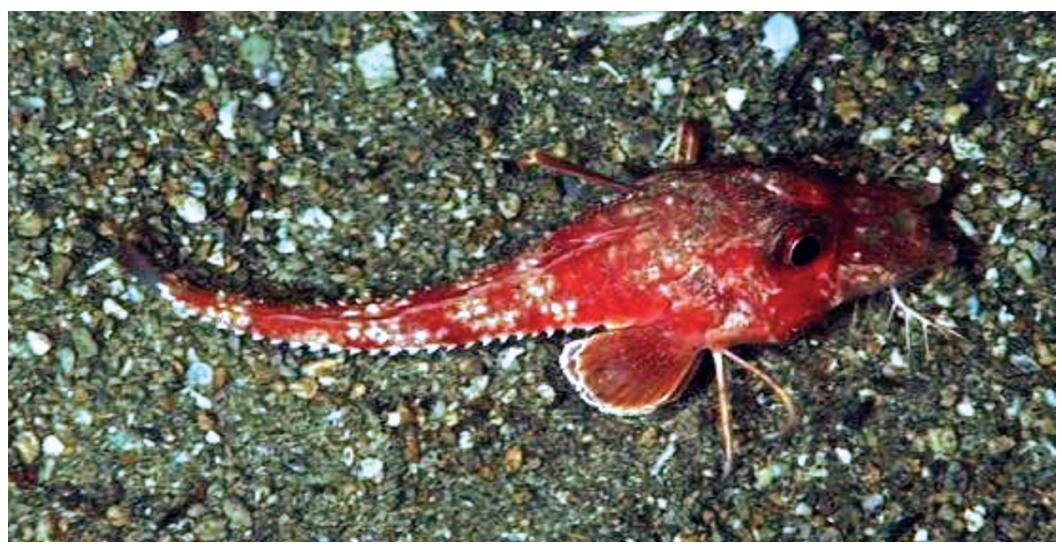

Peristedion nesium at Kili 2 (170 m), 15 May 2007, afternoon.

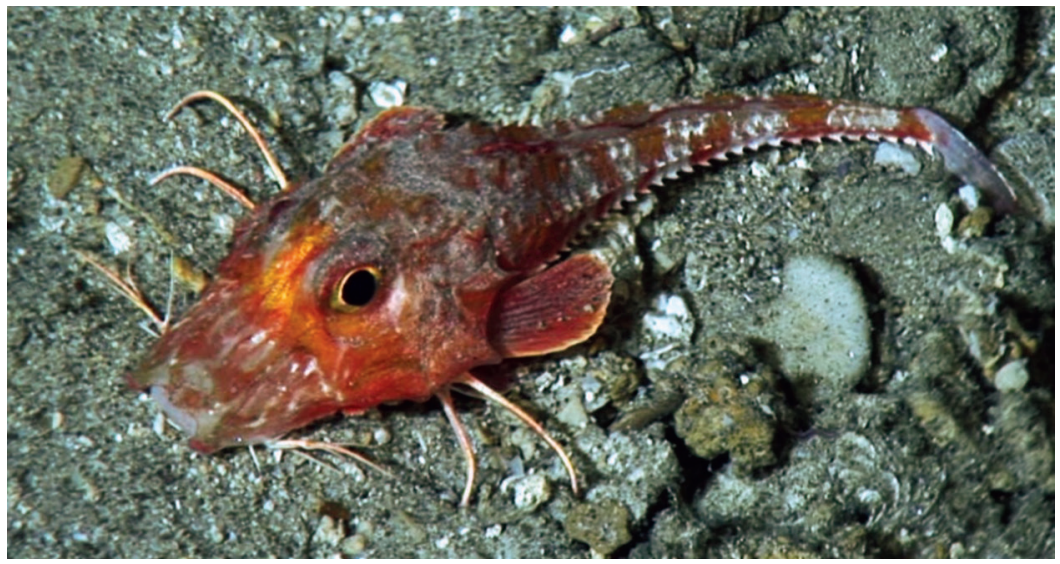

Peristedion nesium at Kili 2 (170 m), 22 January 2007.

DESCRIPTION: Body encased in four rows of spinous scutes on each side of the body; snout wide extended by a pair of flattened bony extensions. Filamentous barbel short. Red head and paler nape. Irregular red bars across body. Pectoral fins bright red, spinous dorsal fin, red with a white margin. Depth: captured between 110-180 m with trawl nets (Bussing, 2010).

Worldwide Distribution: Endemic, only known from Isla del Coco (Bussing, 2010).

Occurrences at Isla del Coco (This study): 130-200 m, Piedra 165 (150-170 m), Kili 2 (170-180 $\mathrm{m}$ ) and at the slope between 130-200 $\mathrm{m}$, in the afternoon.

Previous Reports From Isla Del Coco: Species described with Isla del Coco specimens by Bussing (2010), and reported by Fourriére et al. (2017).

REMARKs: Known maximum depth increases from $180 \mathrm{~m}$ to $200 \mathrm{~m}$. 


\section{Family Serranidae}

Anthias noeli Anderson \& Baldwin, 2000

Rosy Jewelfish / Pez-joya rosada

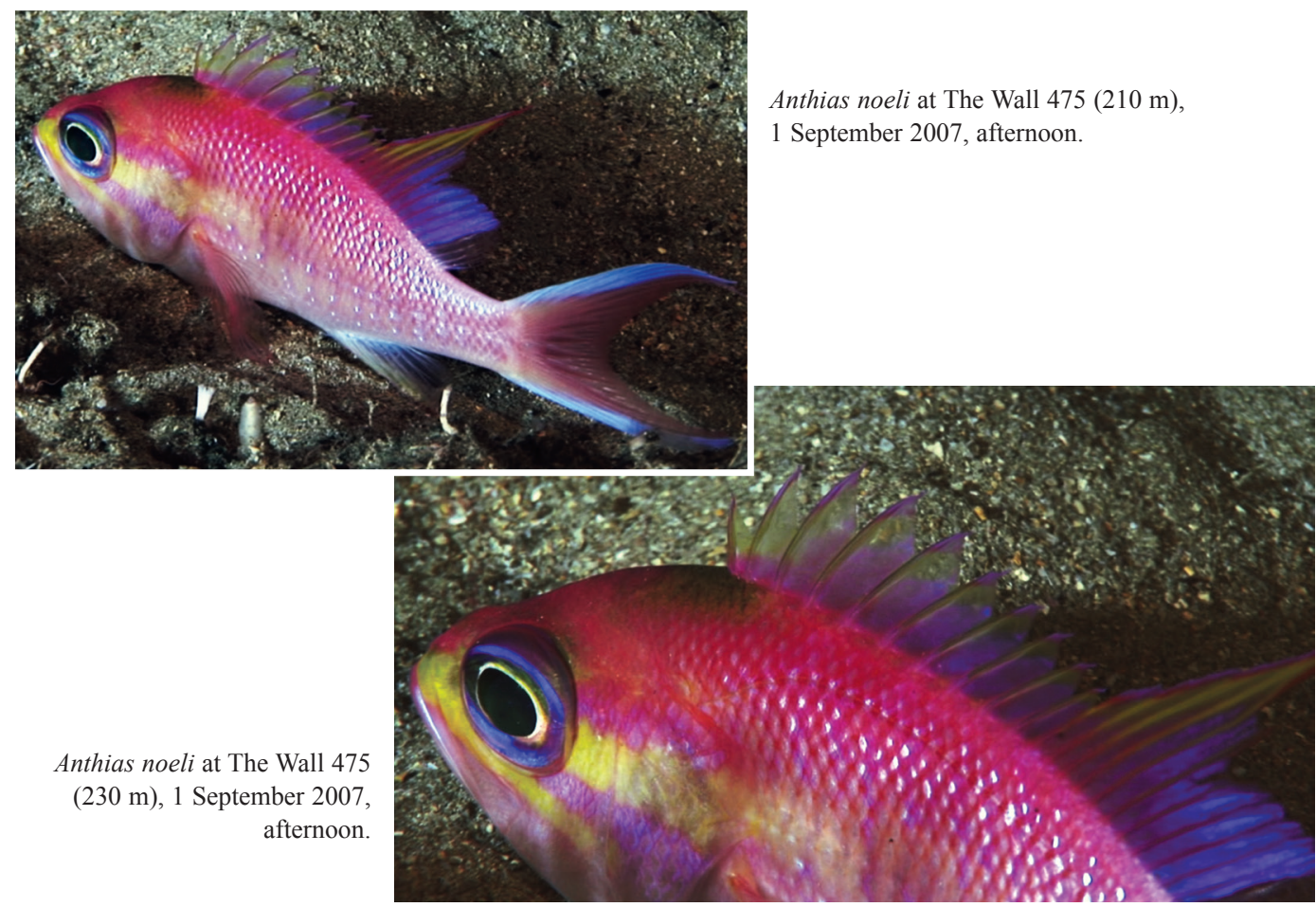

DESCRIPTION: Body elongate, oblong to oval, pink above and paler pink below, iris blue grey with a cream inner ring; a yellow streak across lachrymal and part of cheek, a yellow stripe from posterior margin of eye to superior tip of opercle (Anderson \& Baldwin, 2000; Robertson \& Allen, 2015). A few yellow stripes or blotches on lateral and ventral aspects of body; black blotch present at anterior base of spinous dorsal fin (Anderson \& Baldwin, 2000). Dorsal fin with spiny part silvery and soft part blue-pink, with the long rays yellow; caudal fin reddish to dark pink with upper and lower borders blue-white (Robertson \& Allen, 2015). Two or more soft dorsal-fin rays, one or more soft anal-fin rays, usually first two soft pelvic-fin rays (second longest), and caudal-fin lobes produced (Anderson \& Baldwin, 2000). The species reaches $32 \mathrm{~cm}$, and the known depth range is 100-350 m (Robertson \& Allen, 2015).

Worlwide Distribution: Galápagos (Anderson \& Baldwin, 2000) and Coco islands (Robertson \& Allen, 2015), and mainland Ecuador (Béarez \& Jiménez-Prado, 2003).

Occurrences at Isla del Coco and Las Gemelas Seamount (This study): 90-350 m, Everest (90 m), Las Gemelas 3 (167-262 m), Kili 2 (180 m), at Argo 2 (205 m), Piedra Drop (230-300 m), and The Wall 475 (230-350 m), morning and afternoon.

Previous Reports From Isla del Coco: Starr et al. (2012b) and Fourriére et al. (2017). Minimum known depth decreases from 100 to $90 \mathrm{~m}$. 


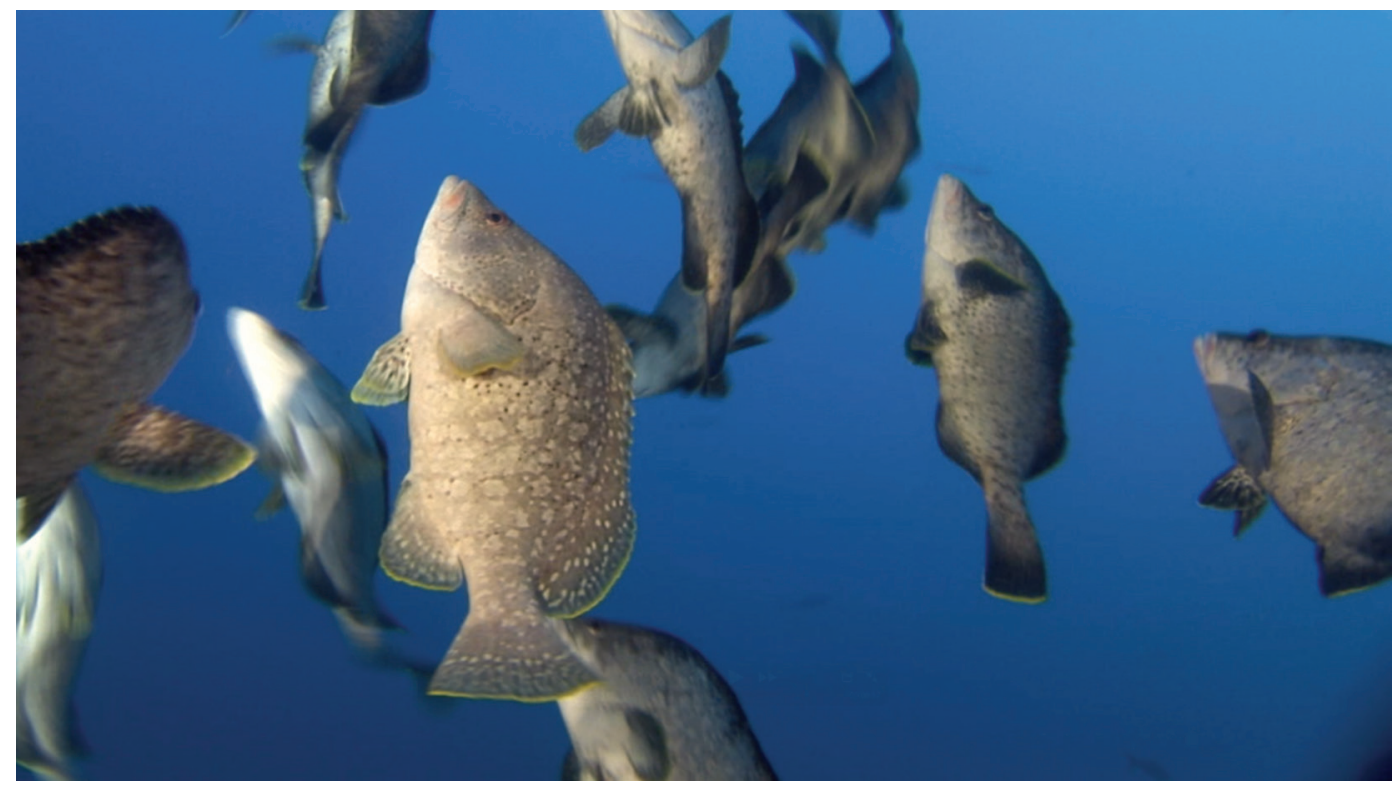

Dermatolepis dermatolepis at Everest (76 m), 31 January 2007, afternoon.
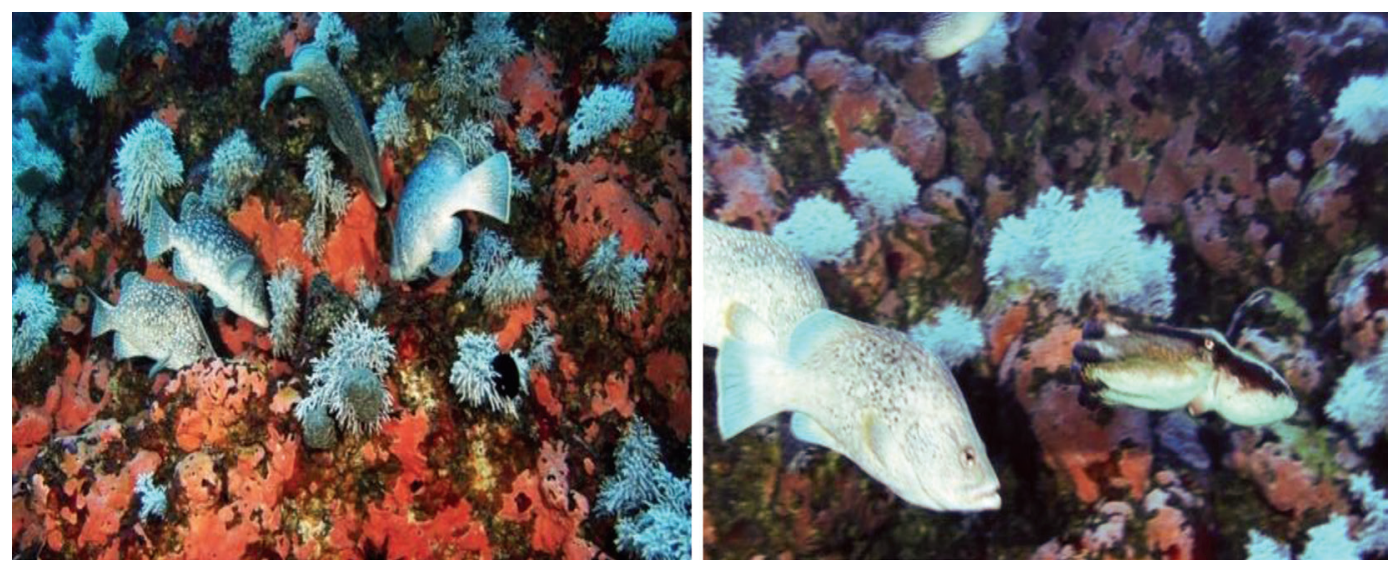

Dermatolepis dermatolepis feeding on a cephalopod at Everest $(60 \mathrm{~m})$,

13 December 2009, afternoon.

DesCRIPTION: Head profile steep, several dark bars on head and body with pale or white interspaces (Bussing \& López, 2005). Body greyish and deep; deepest at origin of dorsal fin (Robertson \& Allen, 2015). Numerous white to pale blotches. Fin margins mostly yellow (Garrison, 2005). Juveniles white with bars on head and body and extending onto dorsal and anal fins. Size: grows to 100 $\mathrm{cm}$. Depth range: down to at least $40 \mathrm{~m}$ (Heemstra, 1995) and $50 \mathrm{~m}$ (Erisman et al., 2009). 


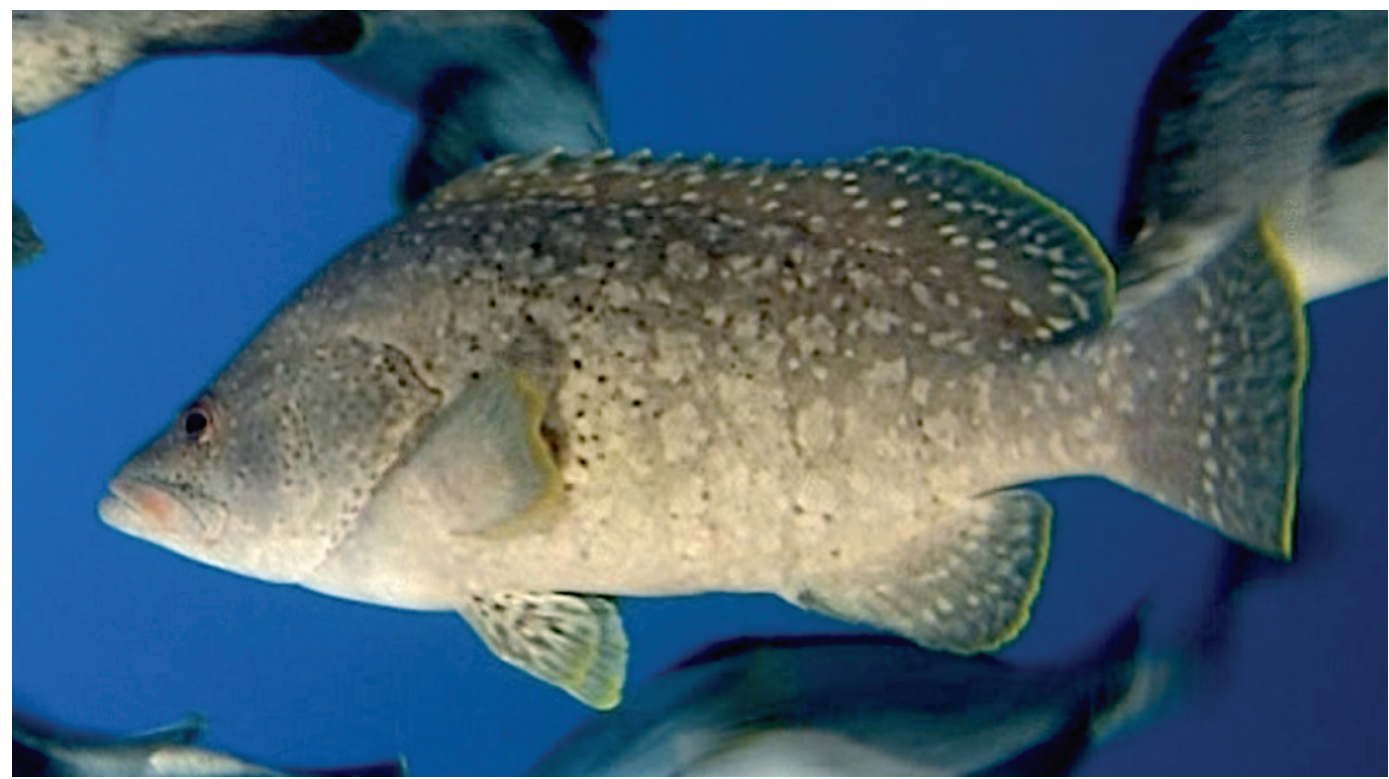

Dermatolepis dermatolepis at Everest (60 m), 13 December 2009.

Worldwide Distribution: Southern California to the central Gulf of California to Ecuador and all the oceanic islands including Isla del Coco (Robertson \& Allen, 2015; Erisman et al., 2009).

Occurrences at Isla del Coco (This study): 45-90 m, Everest (45-90 m), Bajo Manuelita (50-60 $\mathrm{m})$ and The Arch (60-80 m), morning and afternoon.

Previous Reports at Isla del Coco: At Everest (50 m) (Erisman et al., 2009), also in shallow waters (Bussing \& López, 2005; Garrison, 2005), and by Fourriére et al. (2017).

REMARKs: Courtship and spawning behavior were described for this species by Erisman et al. (2009) at Everest and were observed from the DeepSee submersible (at 40-50 m). The mating sequence was characterized by subgroup formation within aggregations of 50-70 individuals followed by a brief vertical spawning rush and gamete release. Known maximum depth is increased by $40 \mathrm{~m}$. 


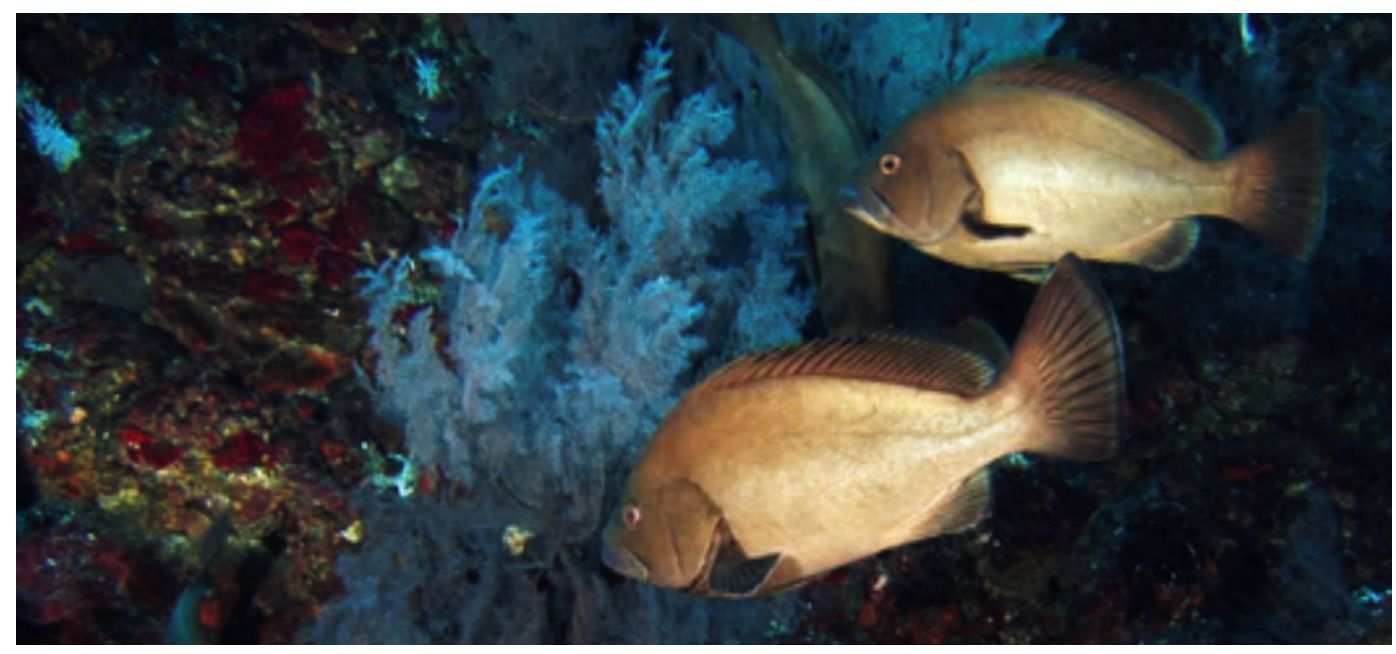

Epinephelus cifuentesi at Everest (84 m), 5 December 2007, morning.

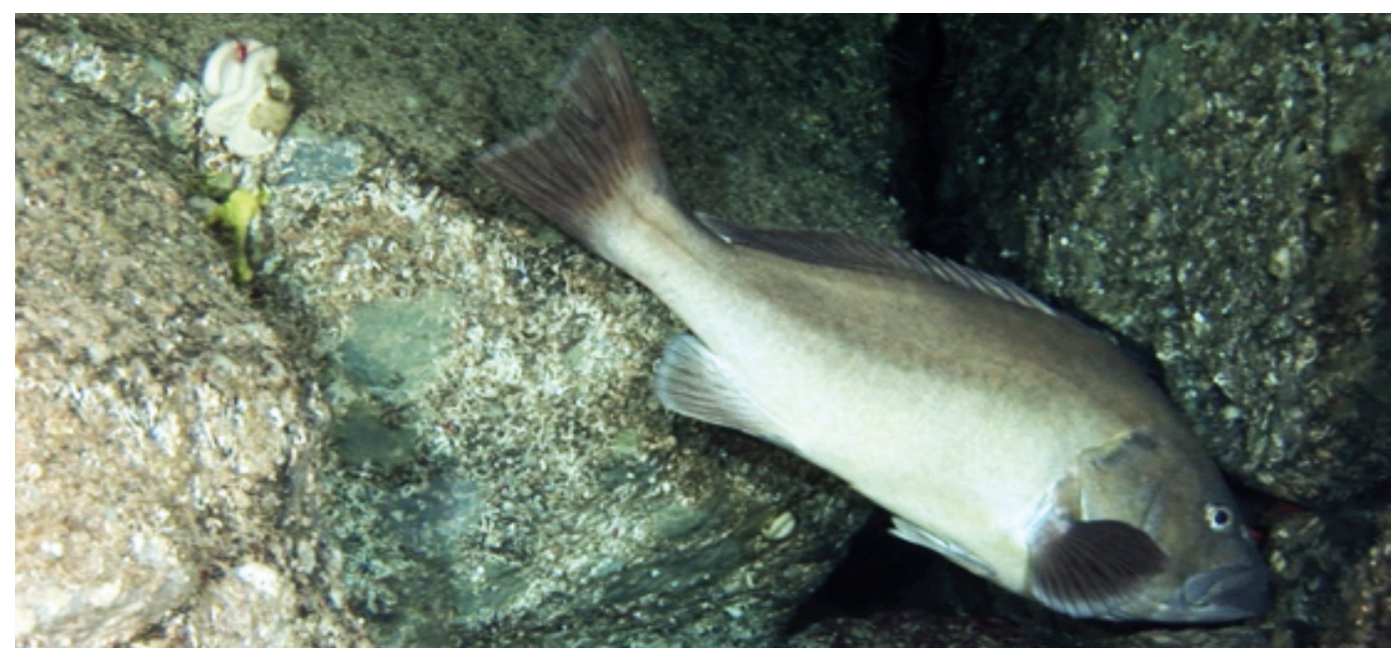

Epinephelus cifuentesi at Piedra 165 (160 m), 4 February 2009, afternoon.

Description: Body solid greenish brown, second dorsal fin longest (Bussing \& López, 2005). Intense green iridescense on body; fins darker, pectoral with intense blue iridescence. Margins of pectoral and anal fins cream. Juveniles are gray-brown with dark line above top jaw. Size: $100 \mathrm{~cm}$. Fishing depth 40-135 m (Heemstra \& Randall, 1993; Robertson \& Allen, 2015).

Worldwide Distribution: Eastern Pacific (McCosker \& Rosenblatt, 2010). The tip of Baja; southern México to Ecuador; Galápagos, Malpelo and Revillagigedo islands, Rocas Alijos (Robertson \& Allen, 2015) and Isla del Coco (Heemstra \& Randall, 1993; Robertson \& Allen, 2015). 


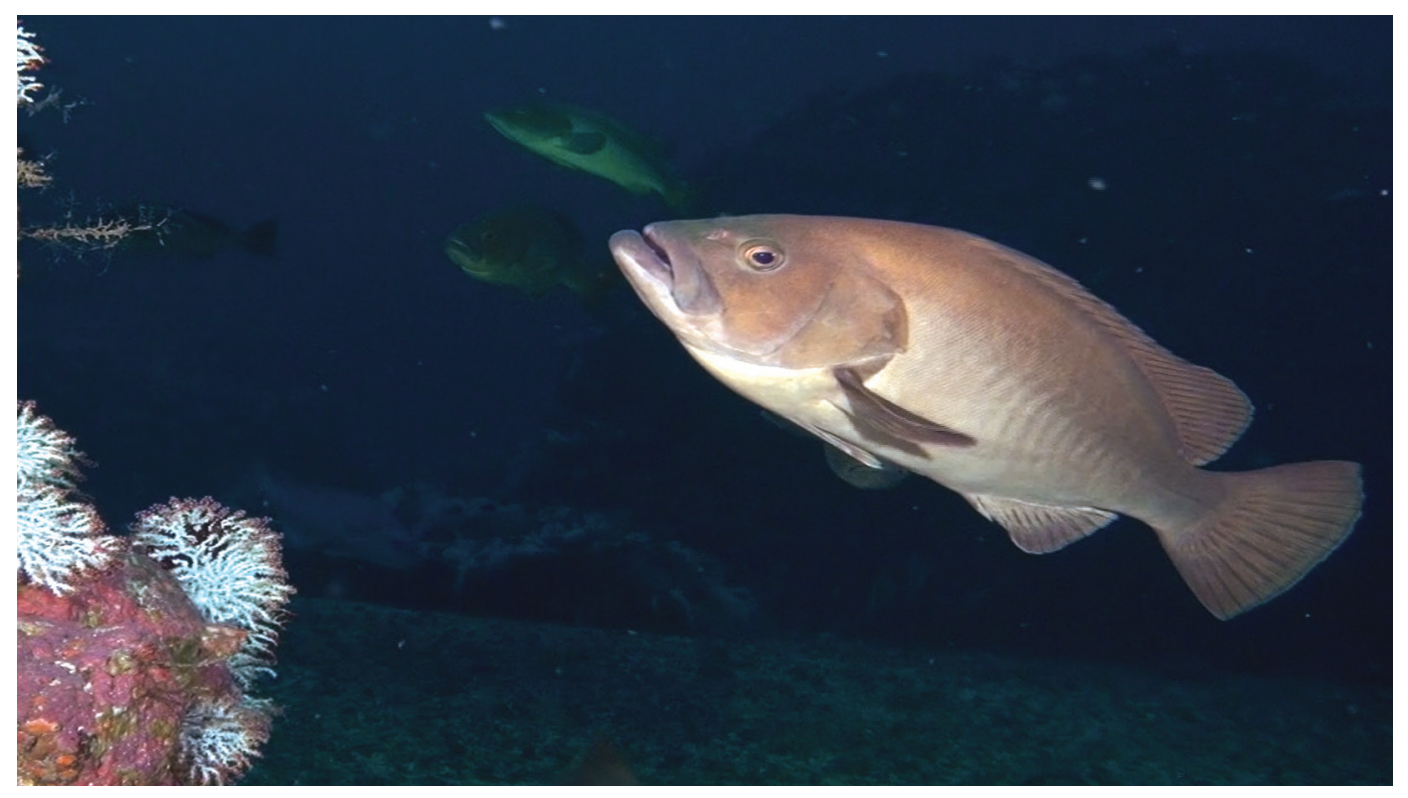

Epinephelus cifuentesi at Everest (60 m), 28 July 2012.

Occurrences at Isla del Coco (This Study): 45-250 m, Everest (45-90 m), The Arch ( $80 \mathrm{~m})$, Arena (110 m), Piedra 165 (160 m), Kili 2 (180 m), The Edge (200-220 m), The Wall 475 (215-250 m), near to Piedra Drop (218 m) and Kili Rock (220 m), afternoon.

Previous Reports from Isla del Coco: Reported by Bussing and López (2005) for Isla del Coco. Cortés and Blum (2008) reported the species at The Arch, and Starr et al. (2012b) in deep waters at more than $50 \mathrm{~m}$. Reported by Fourriére et al. (2017) as a shallow water species.

Remarks: Present observations extend maximum depth reported by Heemstra and Randall (1993) and Robertson and Allen (2015) by $115 \mathrm{~m}$ to $250 \mathrm{~m}$. 
Hyporthodus mystacinus (Poey, 1852)

Misty Grouper / Mero listado

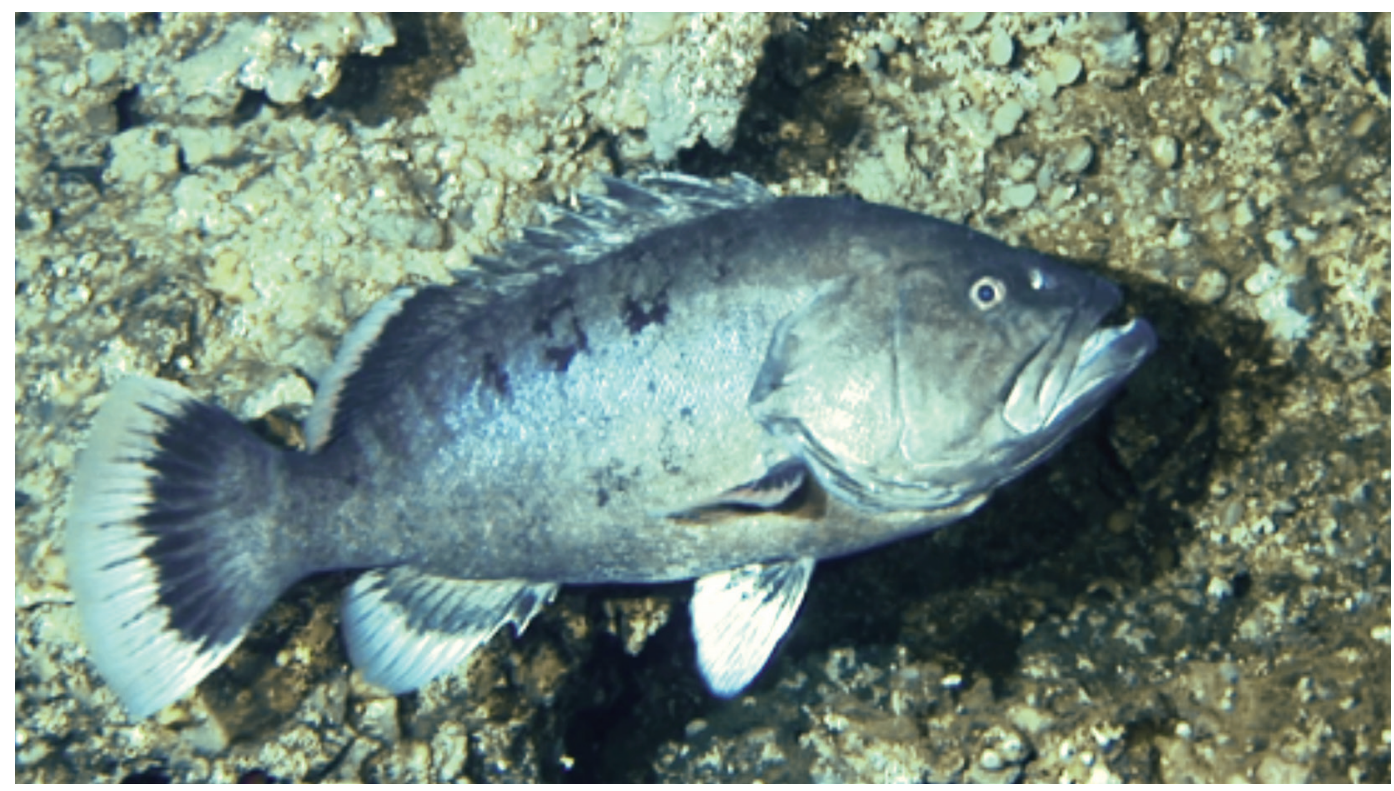

Hyporthodus mystacinus at The Wall 475 (250 m), 29 May 2007, afternoon.
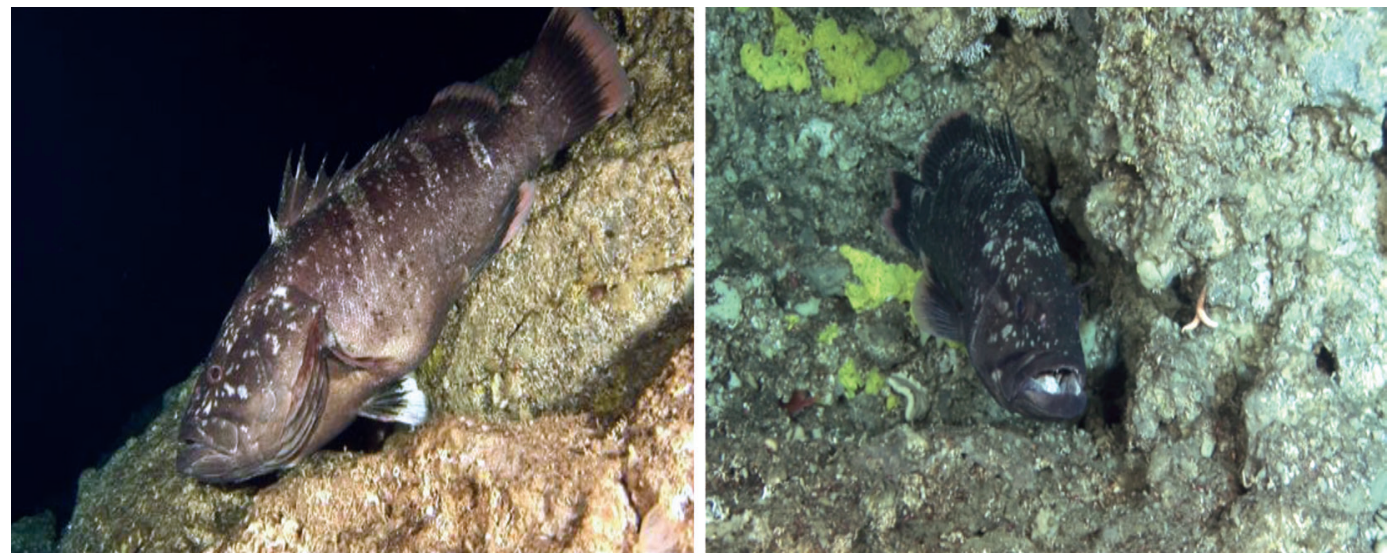

Left, Hyporthodus mystacinus at Piedra 165 (160 m), 6 April 2007, afternoon. Right, H. mystacinus at Piedra 165 (150 m), 15 May 2009, morning.

DESCRIPTION: Body robust; chocolate brown with pales spots and 9-10 dark bars on head and body. Eyes large; tail rounded. Juveniles have stronger colors and also a dark bar across tail base. Dorsal fin with 11 spines (3rd the longest). Size: $115 \mathrm{~cm}$. Depth: 12-400 m. Deep-water species, usually between 100-400 m and juveniles around $30 \mathrm{~m}$ (Heemstra \& Randall, 1993).

Worldwide distribution: Tropical Northeastern Atlantic and Eastern Tropical Pacific: Galápagos Islands and Isla del Coco (Robertson \& Allen, 2015). 


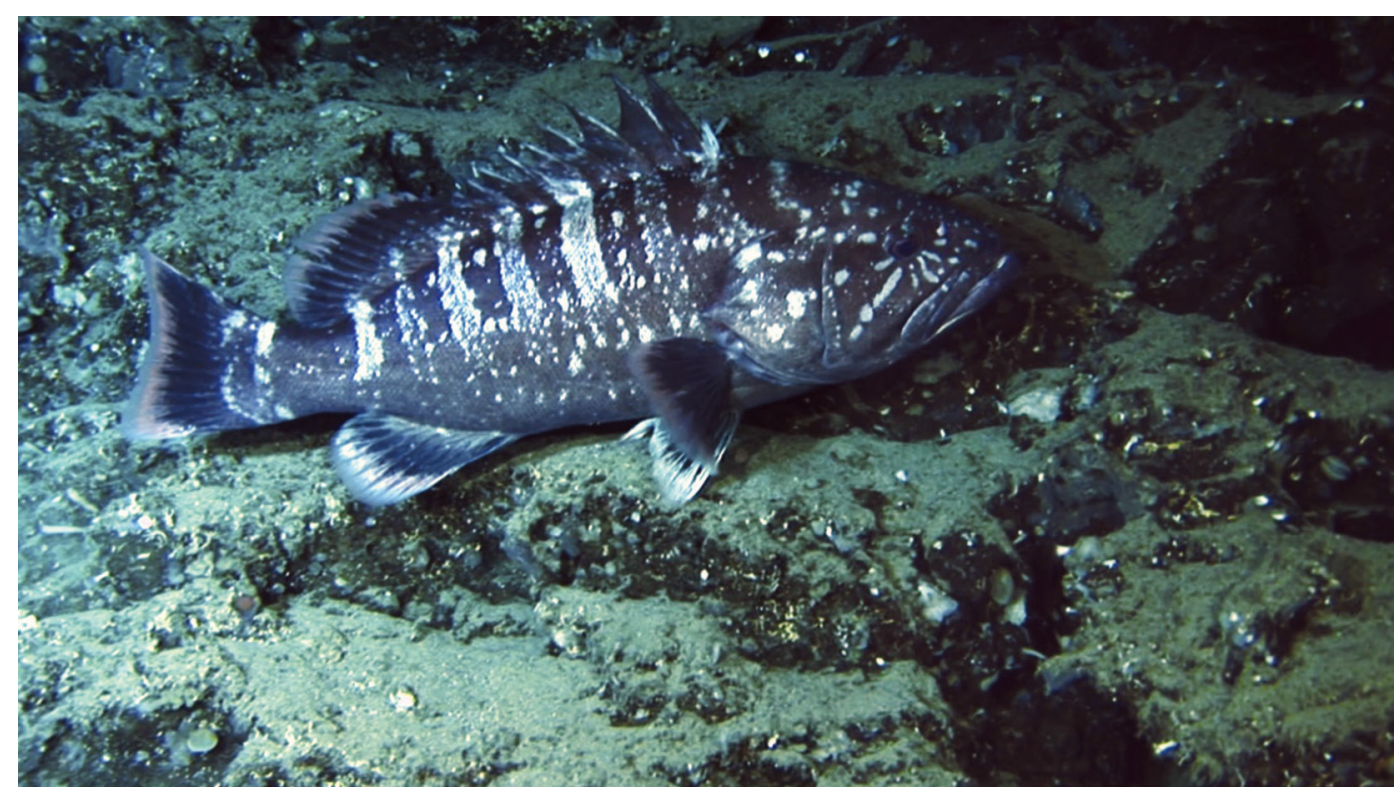

Hyporthodus mystacinus at Piedra 165 (160 m), 20 Apr 2015.

Occurrences at Isla del Coco and Las Gemelas Seamount (This study): 62-330 m; Bajo Manuelita (62 m), The Arch (90 m), morning; The Edge (215 m) and Banana (225 m), afternoon; Everest (80-90 m), Piedra 165 (150-170 m), Kili (170 m), Kili 2 (180 m), Las Gemelas 3 (180 m) and The Wall 475 (220-330 m), morning and afternoon.

Previous Reports From Isla Del Coco: This is the first published report for Isla del Coco. Reported by Fourriére et al. (2017) based on Robertson and Allen (2015) website, who obtained the information of this record for Isla del Coco during the preparation of the present work. 


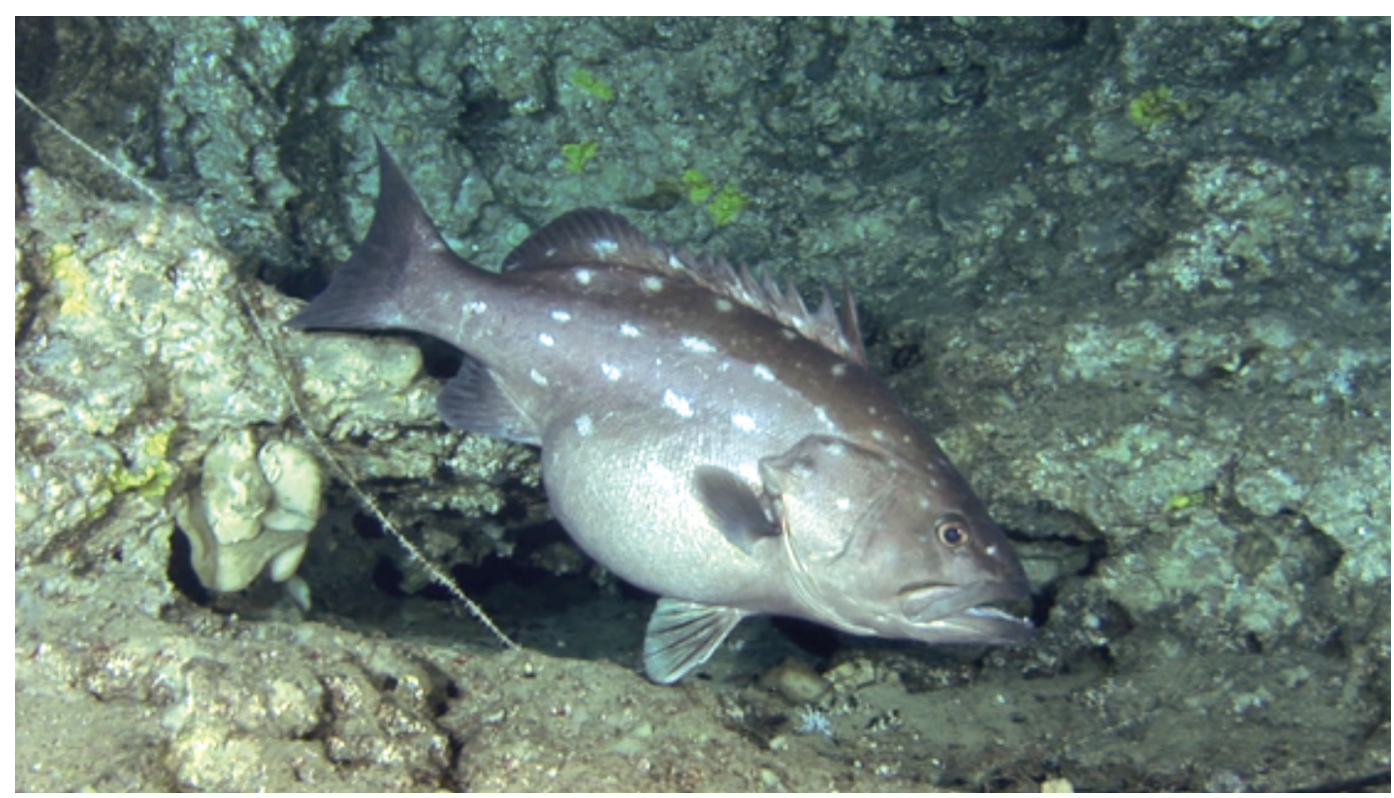

Hyporthodus niphobles (probably a female with eggs) at Piedra $165(170 \mathrm{~m})$, 31 December 2009, morning.
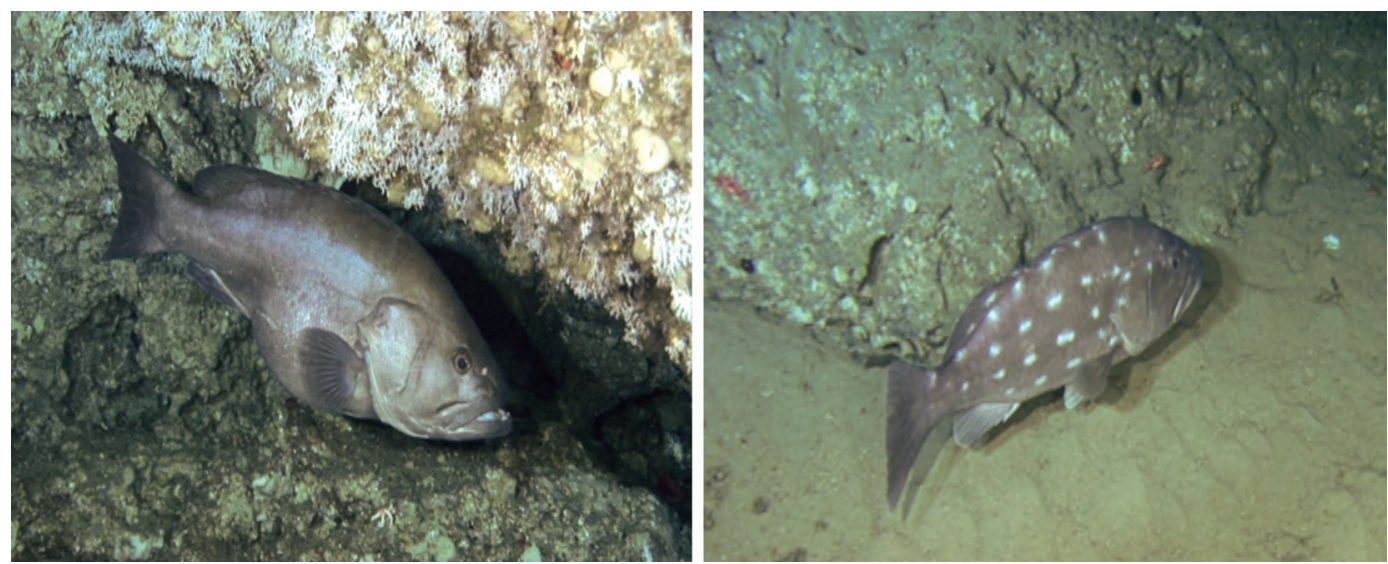

Left, Hyporthodus niphobles at Piedra 165 (165 m), 12 May 2009, afternoon.

Right, juvenile of H. niphobles at Kili 2 (160 m), 10 December 2007, morning.

DESCRIPTION: Adults solid brown or grey, sometimes with several rows of pale spots alog body (Robertson \& Allen, 2015). Body of juveniles with elongated pearl white spots, which are usually absent in large adults (Bussing \& López, 2005). Dorsal rays XI, second spine longest in adults (Robertson \& Allen, 2015). Tail fin dark or pale yellow, pelvics and anal very dark, pectorals clear (Robertson $\&$ Allen, 2015). Adults and juveniles with a dark moustache along margin of upper jaw (Robertson \& Allen, 2015). Size: reaches $121 \mathrm{~cm}$. Depth: 1-450 m (Robertson \& Allen, 2015), mainly in deep waters, and less abundant in reef systems (Heemstra, 1995). 


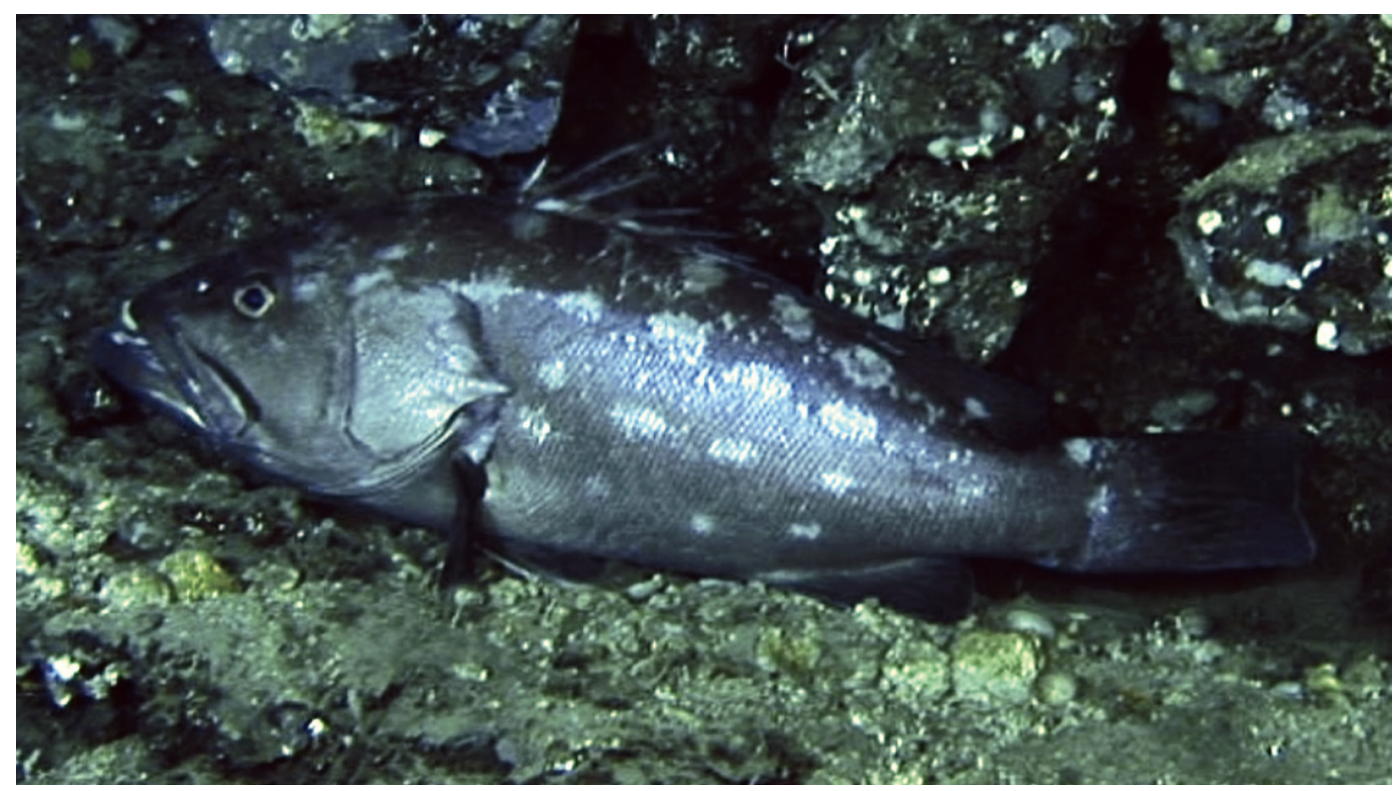

Hyporthodus niphobles at Piedra 165 (160 m), 19 April 2015, morning.

Worldwide distribution: Atlantic and Eastern Pacific (McCosker \& Rosenblatt, 2010), southern California to the Gulf of California to northern Perú (Heemstra, 1995; Aburto-Oropeza et al., 2010), Malpelo and Galápagos Islands (Robertson \& Allen, 2015).

Occurrences at Isla del Coco and Las Gemelas Seamount (This study): 80-450 m; Everest (80-85 m), Las Gemelas 3 (168-271 m), Argo 2 (200 m) and near Piedra Drop (235 m), morning; Kili Rock (220 m) afternoon; Piedra 165 (160-170 m), near Kili (170 m), Kili 2 (180 m), The Edge (200-270 $\mathrm{m})$ and The Wall 475 (230-450 m), morning and afternoon.

Previous Reports from Isla del Coco: Bussing and López (2005). Starr et al. (2012b) reported it deeper than $50 \mathrm{~m}$ at Isla del Coco, and by Fourriére et al. (2017). 
Liopropoma fasciatum Bussing, 1980

Rainbow Basslet / Cabrilla arcoíris

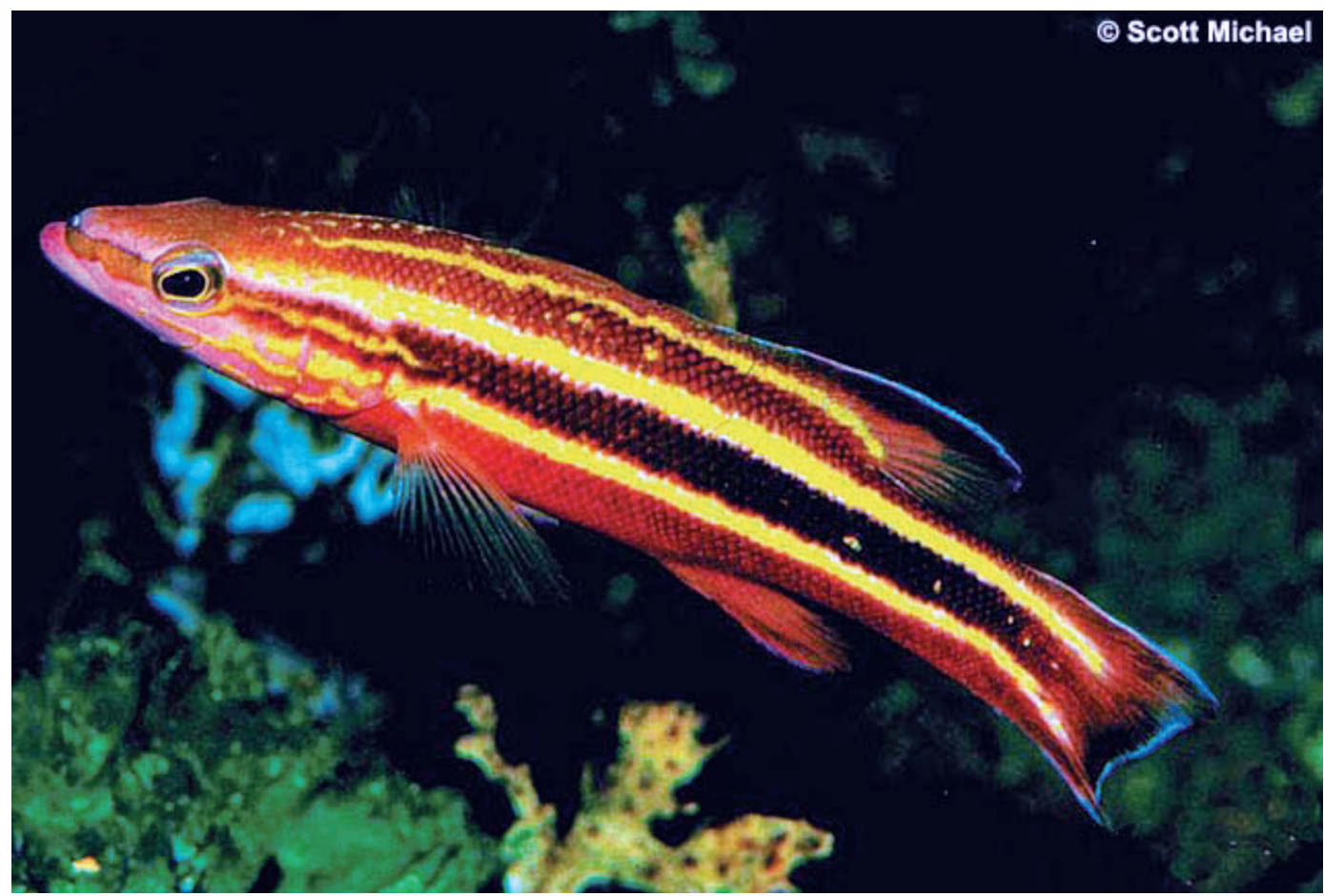

Liopropoma fasciatum photographed in shallow waters. Photograph: Scott Michael.

DesCription: Body MODERATELY ELONGATE AND COMPRESSED; HEAD POINTED WITH NEARLY HORIZONTAL UPPER PROFILE; HEAD AND BACK DARK PINKISH PURPLE, REDDISH BElOW (ROBERTSON \& Allen, 2015). Liopropoma fasciatum is distinguished by a dark brown band from the tip of the snout to the posterior margin of the caudal fin (Bussing, 1980). The midlateral dark band with yellow stripe above and below; a red to brownish stripe below base of dorsal fin with narrow yellow stripe above; dorsal fin black with red base and white edge; anal fin red; caudal fin with two white stripes from flank stripes (Robertson \& Allen, 2015). Reaches $26.5 \mathrm{~cm}$, depth: 25-250 m (Robertson \& Allen, 2015).

Worldwide distribution: Eastern Pacific: Central Gulf of California to Ecuador, Clipperton, Isla del Coco, Malpelo and Galápagos Islands (Béarez \& Jiménez-Prado, 2003; Fourriére, ReyesBonilla, Rodríguez-Zaragoza \& Crane, 2014; Robertson \& Allen, 2015).

Occurrences at Isla del Coco (This Study): 60-160 m, Everest (60-90 m) and Piedra 165 (160 m), morning and afternoon.

Previous Reports from Isla del Coco: Previously reported in shallow waters at Isla del Coco (Garrison, 2005), and by Fourriére et al. (2017) as a deep-water species. 


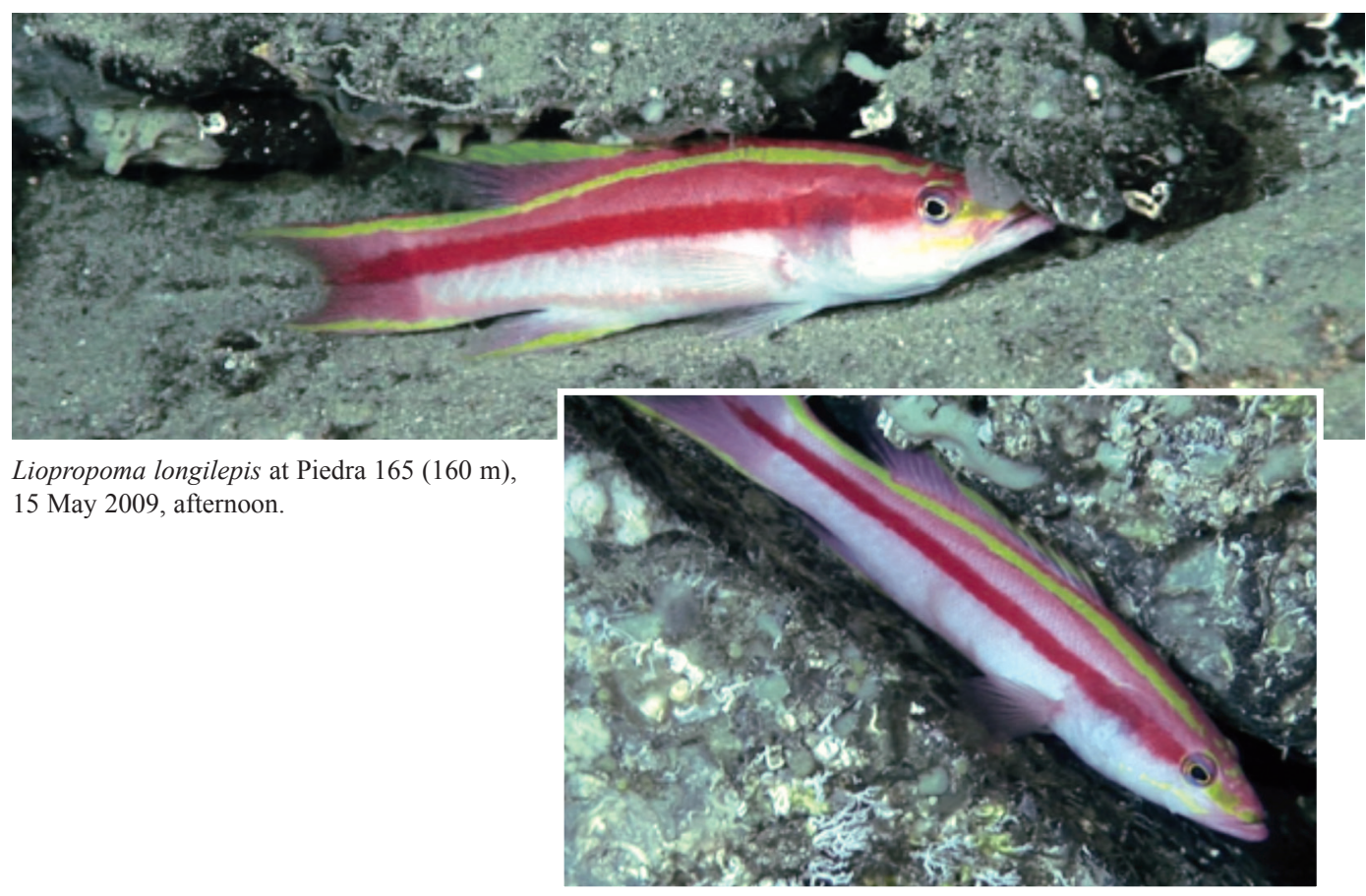

Liopropoma longilepis at Argo 2 (180 m), 5 February 2009, morning.

DESCRIPTION: Body moderately elongate and compressed, head pointed with nearly horizontal upper profile, tail slightly concave (Robertson \& Allen, 2015). Upper head and body pink, whitish below, iris blue-grey; a yellowish stripe from center of rear of eye to tip of snout, a red stripe along the body midline to the tail fin, a yellowish stripe along top of body on each side of midline stripe (Bussing \& López, 2005; Robertson \& Allen, 2015). Outer half of dorsal fin, upper and lower edges of caudal fin and front edge of anal and pelvic fins yellow (Robertson \& Allen, 2015). Size reaches $26 \mathrm{~cm}$, depth range: 50-250 m (McCosker, Merlen, Long, Gilmore \& Villon, 1997; Robertson \& Allen, 2015).

Worldwide distribution: Baja California, Costa Rica and Panamá, Galápagos Islands and Isla del Coco (McCosker et al., 1997; McCosker \& Rosenblatt, 2010; Robertson \& Allen, 2015).

Occurrences at Isla del Coco (This Study): 130-450 m; Argo 2 (180 m) morning; Boulders (250 $\mathrm{m})$, afternoon; Piedra 165 (150-170 m), The Edge (200-215 m) and The Wall 475 (215-450 m), morning and afternoon.

Previous RePORTS From Isla del Coco: Previously reported by McCosker and Rosenblatt (2010) at $164 \mathrm{~m}$, and by Fourriére et al. (2017) as a deep-water species.

Remarks: Present observations extend, by $200 \mathrm{~m}$, the maximum depth reported by McCosker and Rosenblatt (2010) for Isla del Coco, and by McCosker et al. (1997) for the Eastern Pacific region. 


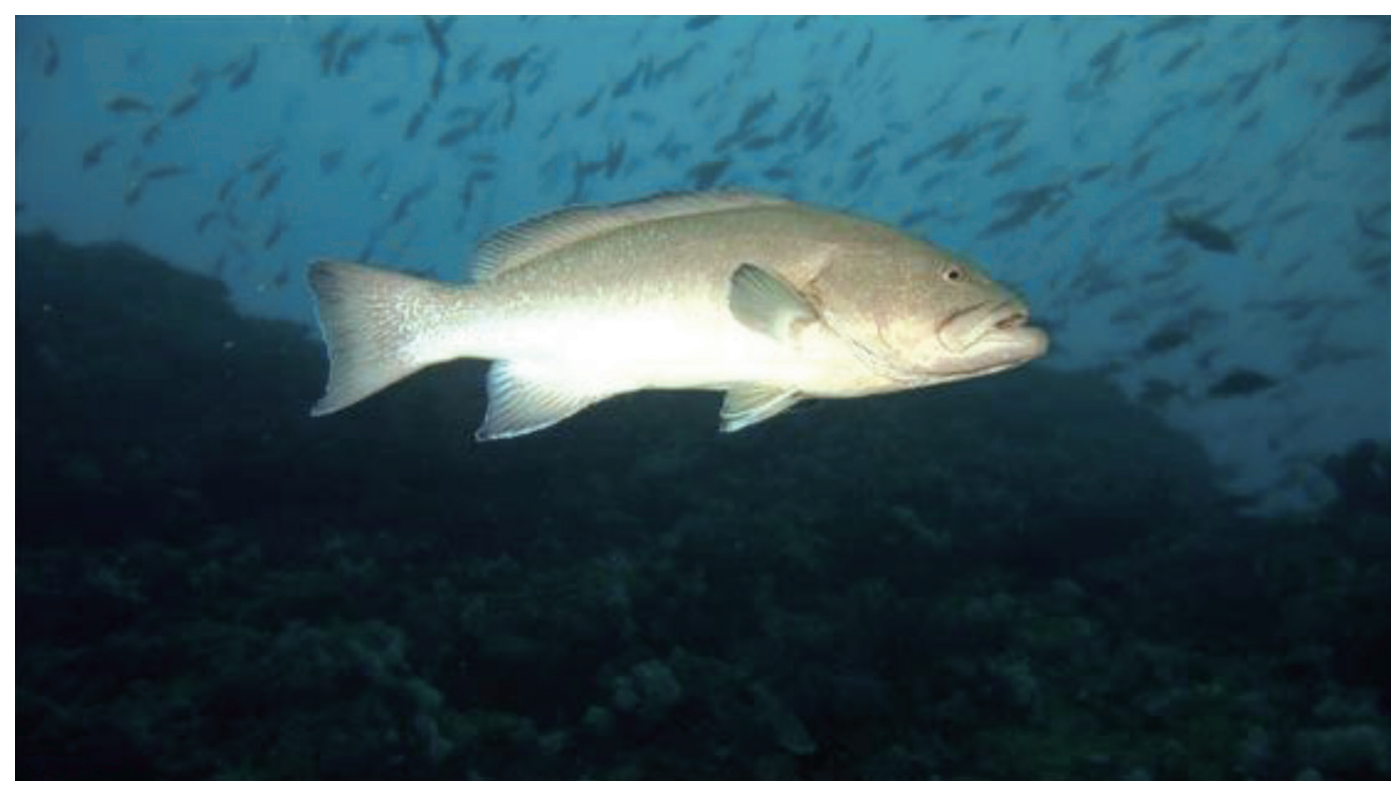

Mycteroperca olfax at Everest (90 m), 9 April 2009, afternoon.

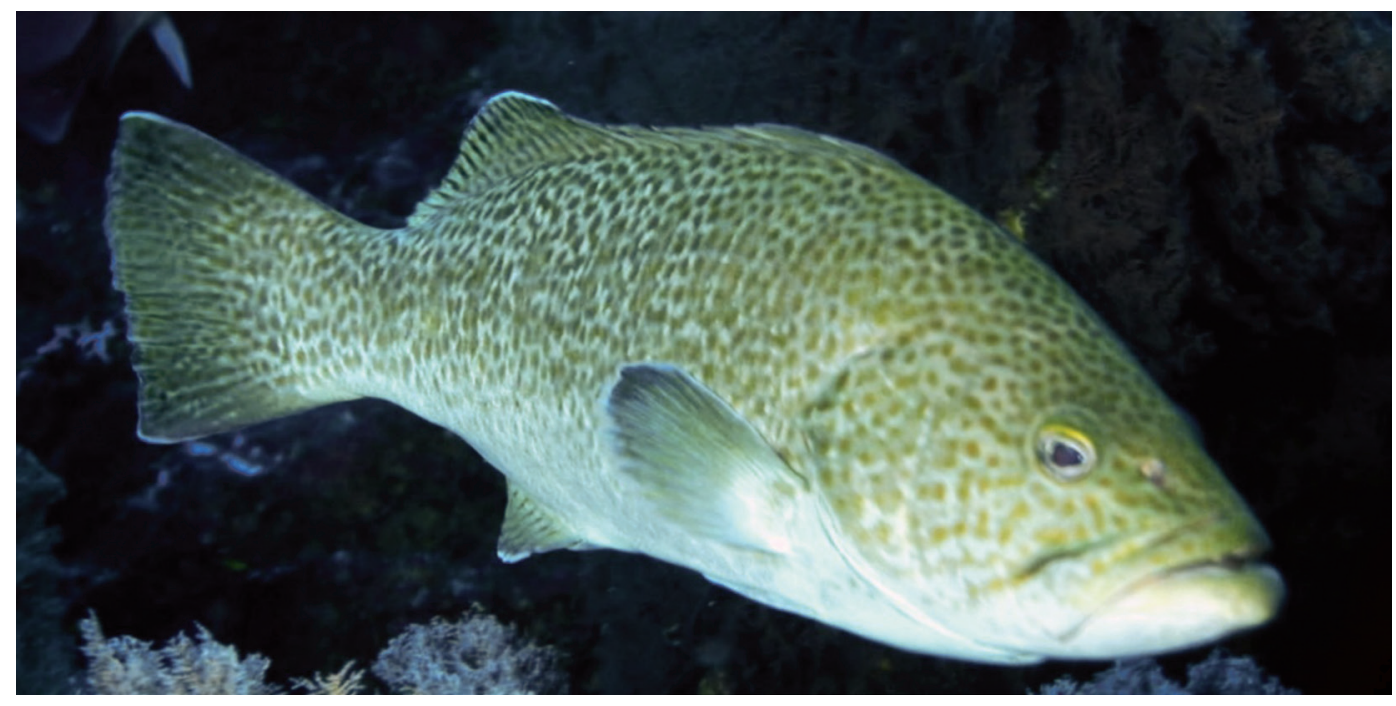

Mycteroperca olfax at Everest (60 m), 9 April 2009.

DesCRIPTION: Head and body pale grey-brown with numerous close-set brown spots (Robertson \& Allen, 2015). Sometimes with dark bars on upper sided (Bussing \& López, 2005) that tend to disappear with age (Heemstra, 1995). Rare bright yellow individuals exist (Bussing \& López, 2005; Robertson \& Allen, 2015). Edge of tail straight, lower jaw projecting (Robertson \& Allen, 2015). Reaches at least $120 \mathrm{~cm}$; depth: 5-100 m (Robertson \& Allen, 2015). 


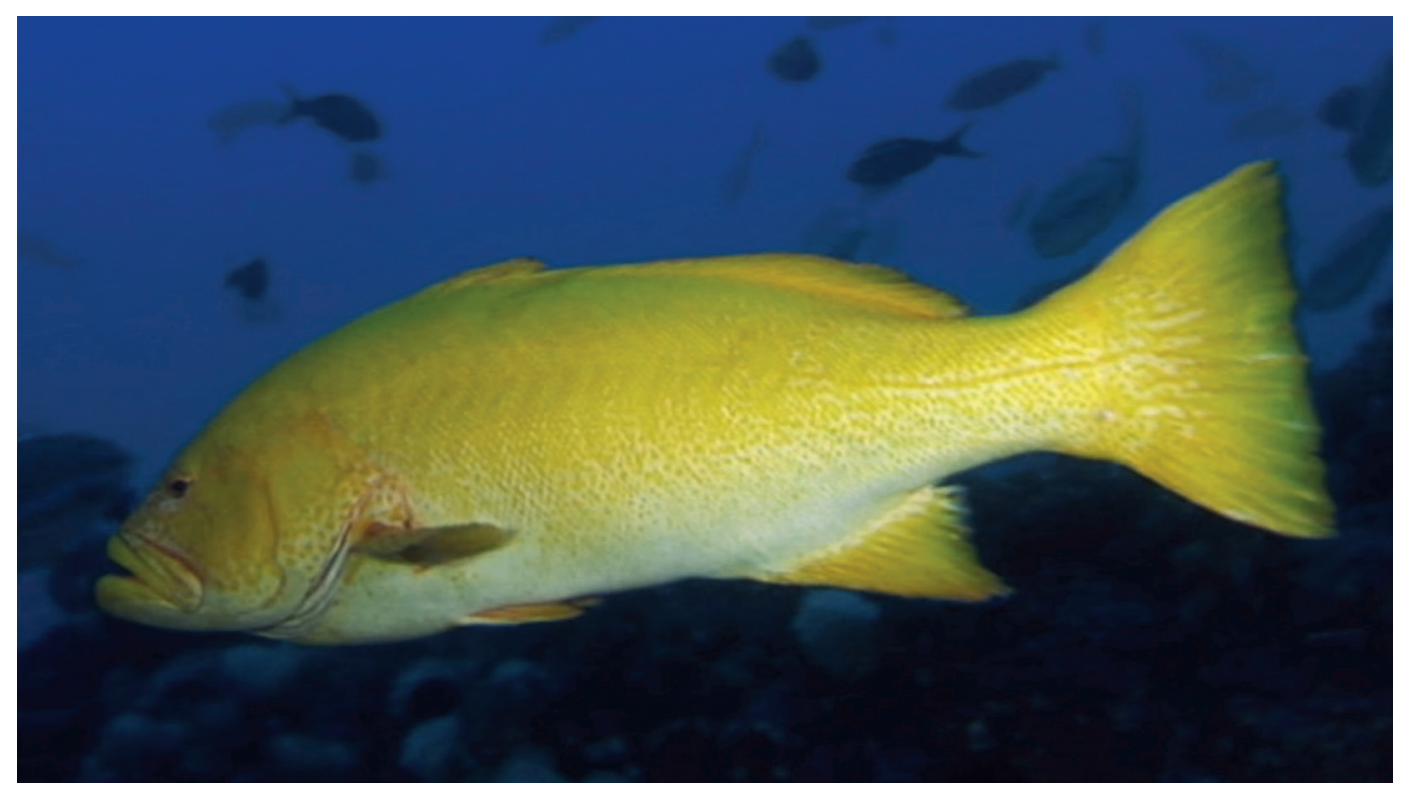

Mycteroperca olfax (yellow phase) at Everest (50 m), 9 April 2009.

Worldwide Distribution: Galápagos, Isla del Coco and Malpelo (Garrison, 2005; McCosker \& Rosenblatt, 2010; Robertson \& Allen, 2015). Occasionally found between central Colombia and northern Perú (Robertson \& Allen, 2015).

Occurrences at Isla del Coco (This Study): 50-180 m, The Arch (90 m) and Kili 2 (180 m), morning; Bajo Manuelita (62 m) and Everest (50-90 m), morning and afternoon.

Previous Reports From Isla del Coco: In shallow waters by Bussing and López (2005), and at Dos Amigos (Grande and Pequeño), Roca Sucia and Punta María (Garrison, 2005); also, deeper than 50 $\mathrm{m}$ by Starr et al. (2012b), and by Fourriére et al. (2017) as a shallow water species.

Remarks: Present observations extend maximum depth reported by Robertson \& Allen (2015) to $180 \mathrm{~m}$. 


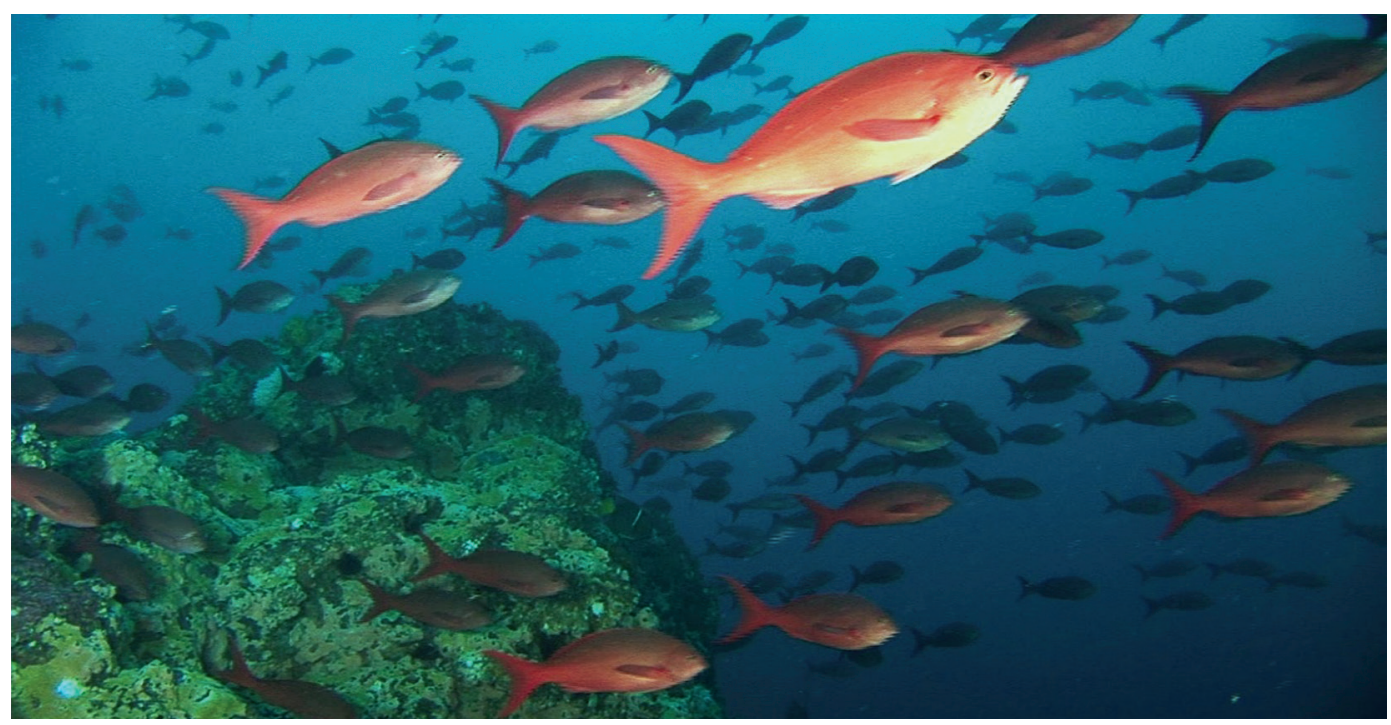

Paranthias colonus at Everest (80 m), 26 May 2007, afternoon.

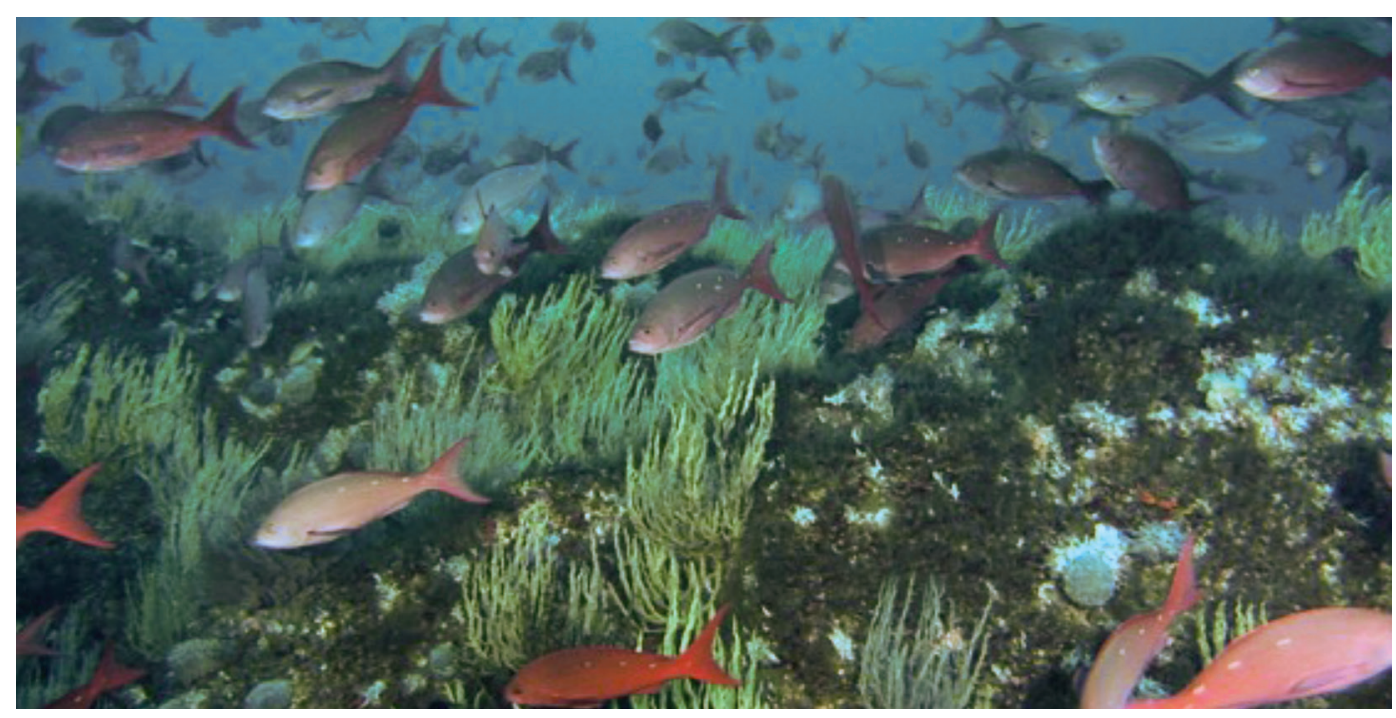

Paranthias colonus among black corals at The Arch (80 m), 15 January 2008, afternoon.

DESCRIPTION: Form larger midwater schools while feeding on plankton. Body elongate, fusiform, tail strongly concave (Robertson \& Allen, 2015). Reddish or reddish grey body color with 2-3 bright blue or violet spots on dorsal part of the body and another 2 on caudal peduncle. Juveniles are pinkish-yellow, usually with 5 dark dorsal dots; adults are greenish brown dorsally and reddish below, with 5 white spots on the back (Robertson \& Allen, 2015). Reaches up to $36 \mathrm{~cm}$ (Robertson \& Allen, 2015), depth: 10-70 m (Heemstra, 1995), down to 120 m (Aburto-Oropeza et al., 2010). 


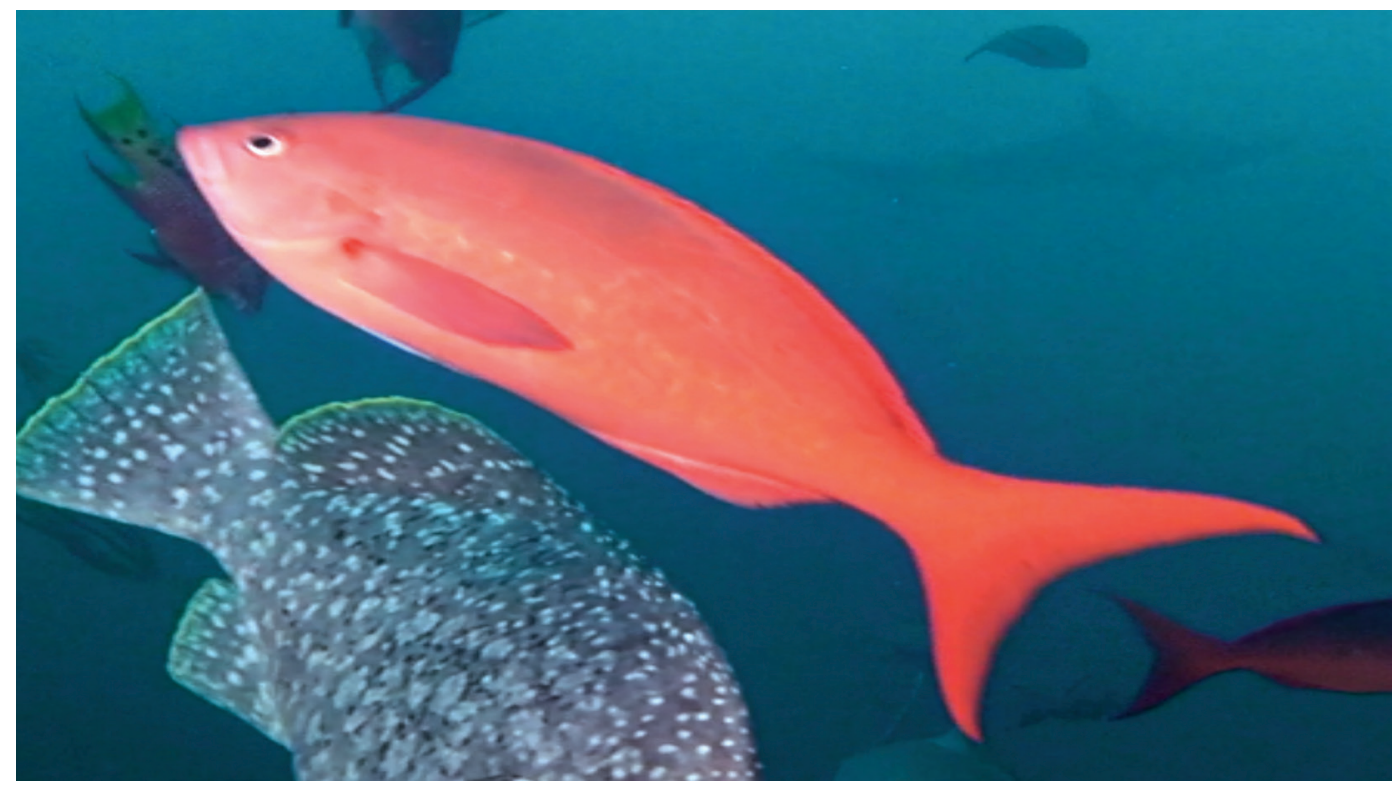

Paranthias colonus at Everest (50 m), 11 May 2013.

Worldwide Distribution: From Baja California including the central Gulf of California to Perú and all the Eastern Tropical Pacific oceanic islands (Robertson \& Allen, 2015).

OCCurRences at Isla del Coco (This Study): 45-90 m; on the way to Kili 2 (90 m) in the morning; Everest (45-90 m) and The Arch (80 m), morning and afternoon.

Previous Reports from Isla del Coco: Reported by Bussing and López (2005) and by Garrison (2005) in shallow waters down to at least $43 \mathrm{~m}$. 
Threadfin Bass / Serrano baga

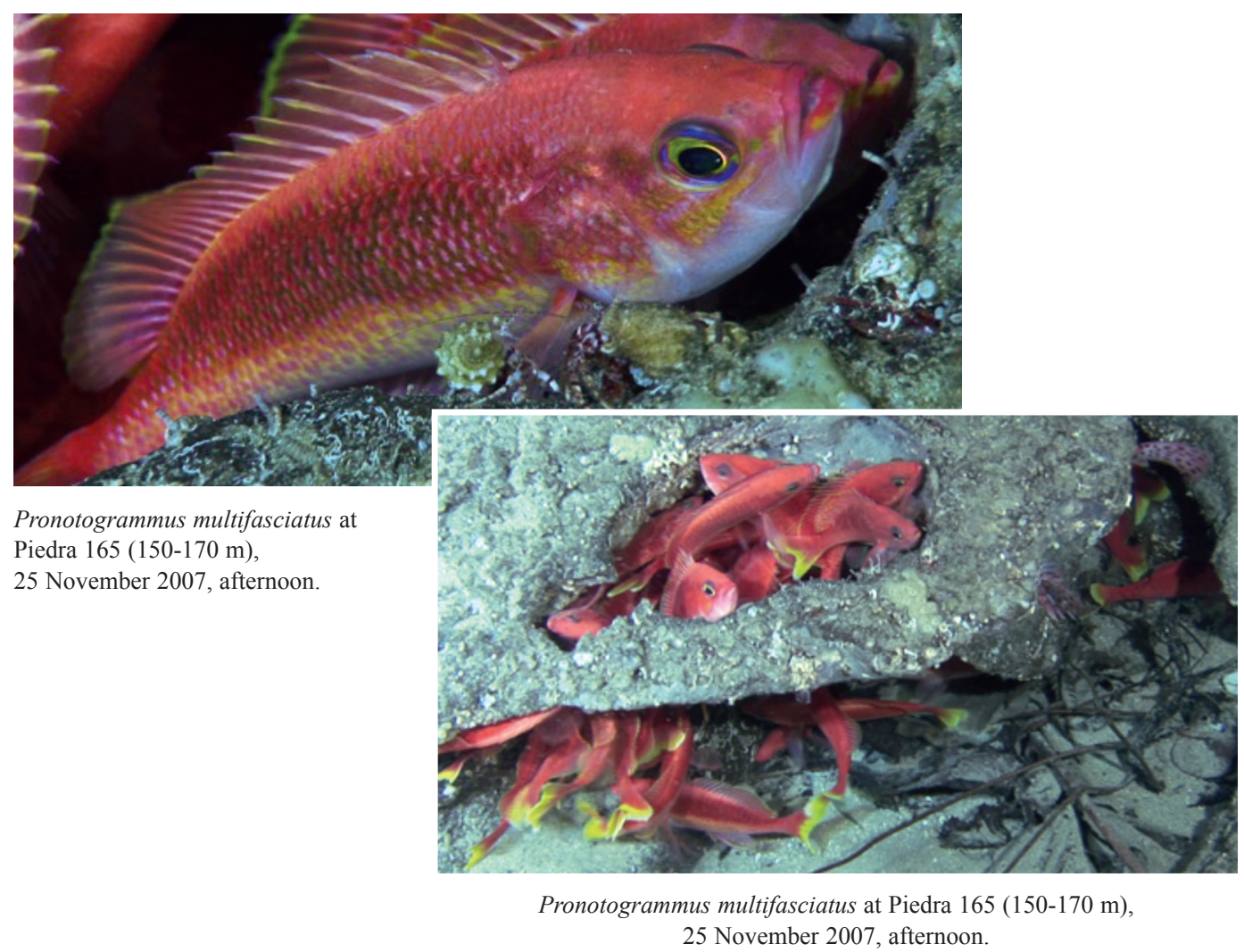

DesCRIPTIOn: Body elongate, strongly compressed (Robertson \& Allen, 2015). Head and body rose color, yellow stripe below eye (Bussing \& López, 2005), upper body with several thin short irregular dark bars (Heemstra, 1995), lower body with yellow mottling (Robertson \& Allen, 2015). Tail forked, tips pointed. Rear edge of tail broadly yellow, angular tips; fins red with yellow edges (Robertson \& Allen, 2015). Size to $26 \mathrm{~cm}$, depth 40-300 m (Robertson \& Allen, 2015). Heemstra (1995) reported that it has been captured by commercial fishermen to a depth of $400 \mathrm{~m}$.

Worldwide Distribution: From California to northern Perú, and the Revillagigedo, Galápagos, Coco and Malpelo islands (Aburto-Oropeza et al., 2010; McCosker \& Rosenblatt, 2010; Robertson \& Allen, 2015).

Occurrences at Isla del Coco and Las Gemelas Seamount (This study): 80-220 m; Argo 2 (205 $\mathrm{m})$, Kili Rock (220 m) and Banana (225 m), afternoon; Piedra 165 (150-170 m), Las Gemelas 3 (170-217 m), Kili 2 (180 m) and The Edge (200-220 m), morning and afternoon.

Previous Reports from Isla Del Coco: Reported by Bussing and López (2005) in shallow waters, and by Starr et al. (2012b) at depths greater than 50 m, and by Fourriére et al. (2017) as a deepwater species. 


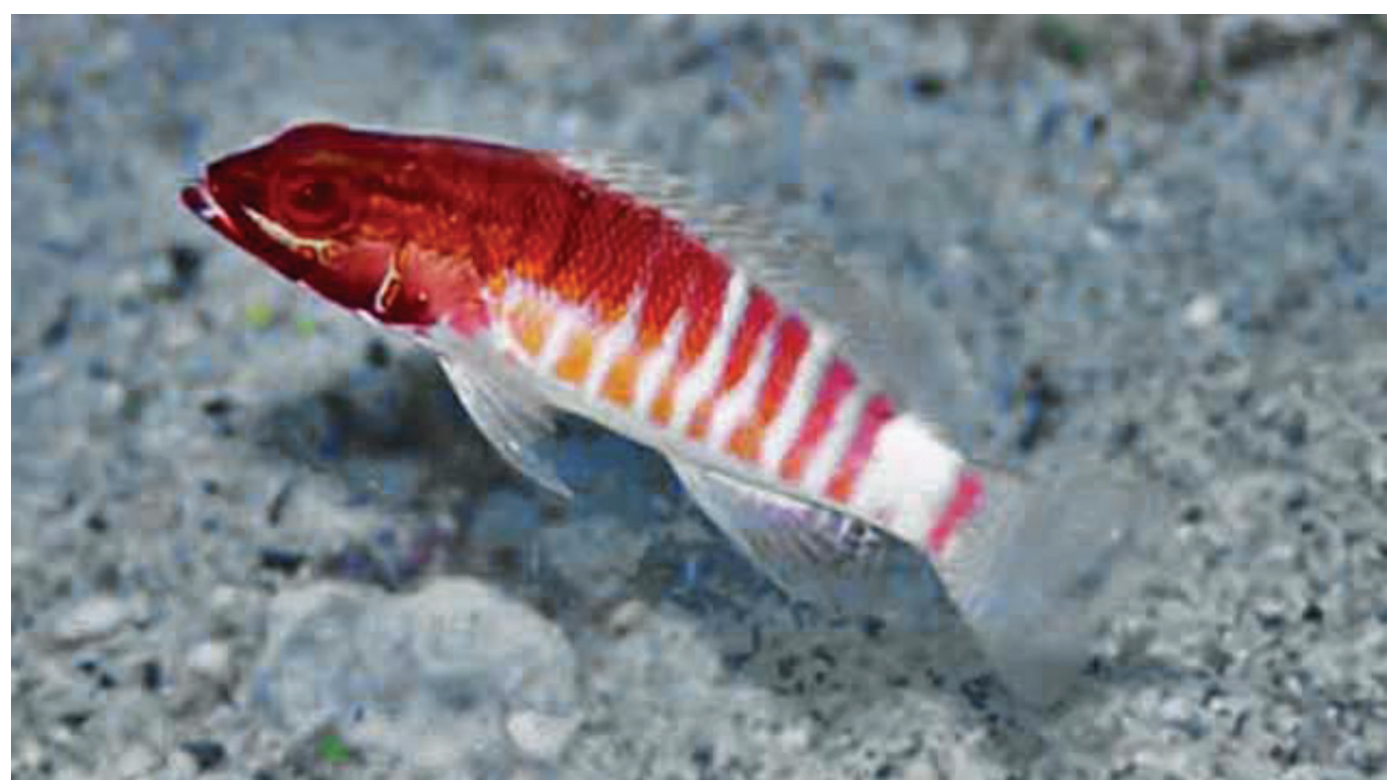

Serranus tico photographed in shallow waters by Ross Roberstson.

DESCRIPTION: Body elongate and moderately depressed. Head and nape red brown, with a thin dark stripe behind top of eye, another above eye; a white stripe under eye. A blackish blotch and small orange spots on lower preopercle. Body with about eight long, narrow bars, red on upper part and yellow to orange below; a broad whitish bar across tail base (Robertson \& Allen, 2015). Size: to at least $8.5 \mathrm{~cm}$ (Robertson \& Allen, 2015). Depth: 10-43 m (Robertson \& Allen, 2015).

Worldwide Distribution: Endemic to Cocos and Malpelo islands (Robertson \& Allen, 2015).

Occurrences at Isla del Coco (This study): From shallow waters to Bajo Manuelita (60 m).

Previous Reports from Isla del Coco: Bussing and López (2005), Garrison (2005), and by Fourriére et al. (2017) as a shallow species.

REMARKs: Present observations extend depth range reported by Robertson and Allen (2015) to $60 \mathrm{~m}$.

Note: Our images available from deep waters are of very poor quality, reason why we use this shallow water photograph. 


\section{Family Opistognathidae \\ Opisthognathus sp. \\ Jawfish / Bocón}

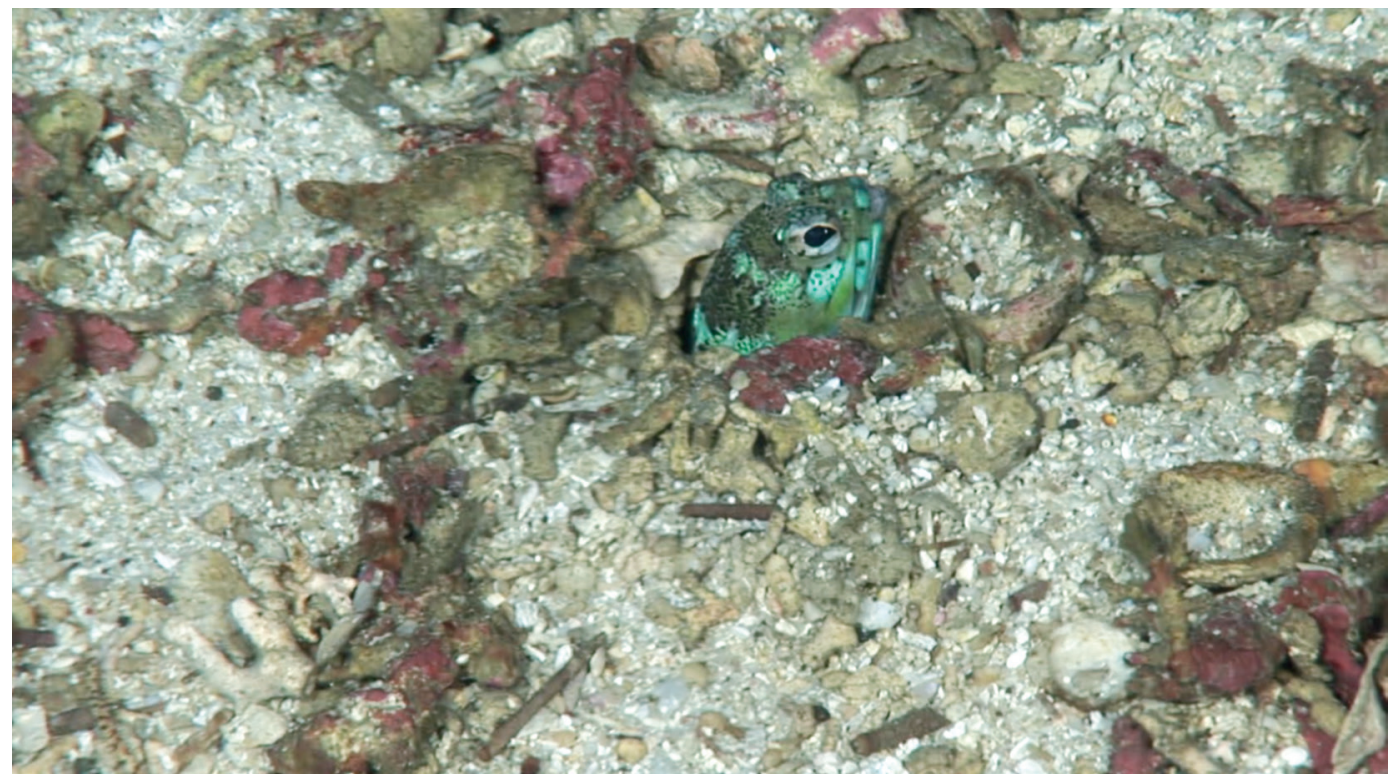

Opisthognathus sp. at Everest (80 m), 22 August 2006, afternoon.

DeSCRIPTION: Jawfishes have an enlarged bulbous head, with eyes large and high on head, and a large mouth. They construct elaborate burrows by scooping sand or small stones with their mouth, and frequently line and reinforce their burrows with pebbles or shell fragments. There are 12 species in two genera in the Eastern Tropical Pacific (Robertson \& Allen, 2015). This species appears to be a new and probably endemic species.

WORLDWIDE DISTRIBUTION: Jawfishes occur in all warm seas of the world.

Occurrences at Isla del Coco (This study): Everest (45-80 m), morning and afternoon.

PreVious RePORTS FROM IsLA DEL COCO: Only Opistognathus panamaensis reported previously for Isla del Coco (Robertson \& Allen, 2015), which, unlike the image of the present species, has a yellow head with blue spots. 


\section{Family Priacanthidae}

Cookeolus japonicus (Cuvier, 1829)

Bulleye / Catalufa aleta larga

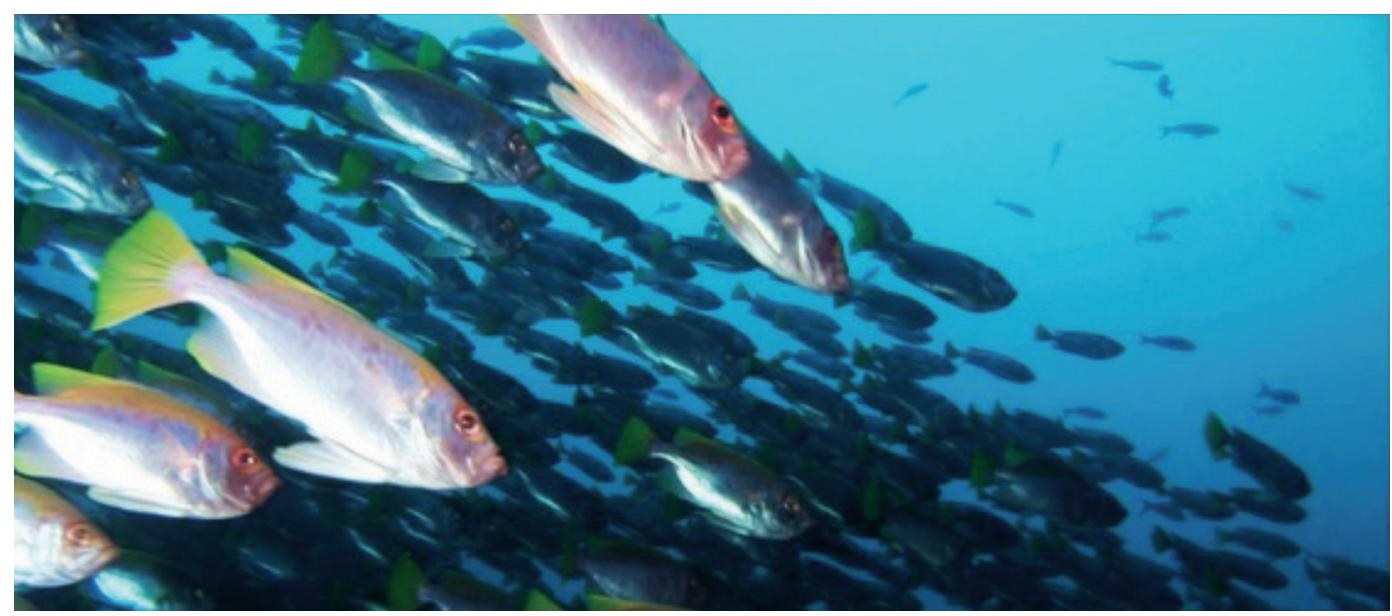

Cookeolus japonicus over Everest (45 m), 26 May 2007, afternoon.

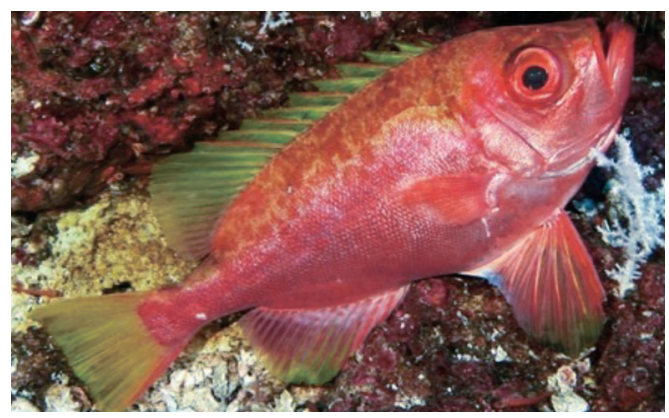

Cookeolus japonicus at Everest $(70 \mathrm{~m})$, 17 May 2007, morning.

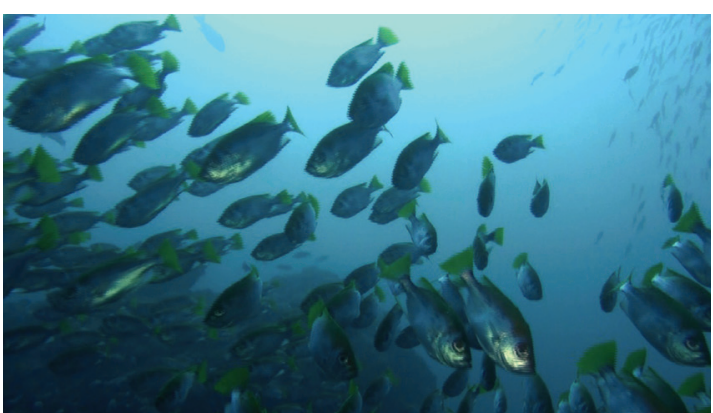

Cookeolus japonicus at Everest (60 m), 06 November 2012.

DesCriPtion: Bright red (Bussing \& López, 2005), including iris of eye (Robertson \& Allen, 2015). All fins transparent with tinges of yellow. Eyes big and tail fin slightly rounded (Garrison, 2005). Attains $68 \mathrm{~cm}$; depth: mostly deep waters (100-400 m) around islands (Starnes, 1995), but occasionally to $30 \mathrm{~m}$ (Robertson \& Allen, 2015).

Worlwide Distribution: Circumglobal in tropical seas (Robertson, 2008; McCosker \& Rosenblatt, 2010); in the Eastern Pacific from the Gulf of California to Perú and the Revillagigedo, Malpelo and del Coco islands (Robertson \& Allen, 2015).

Occurrences at Isla del Coco (This study): 45-300 m, Bajo Manuelita (60 m), Everest (45-80 m) and The Arch (70 m), morning and afternoon, off Piedra 165 on the wall $(300 \mathrm{~m})$.

Previous reports from Isla del Coco: Reported in deep waters (The Arch) by Cortés and Blum (2008). Few sightings in shallow waters, mainly at Alcyone (Garrison, 2005), and by Fourriére et al. (2017). 


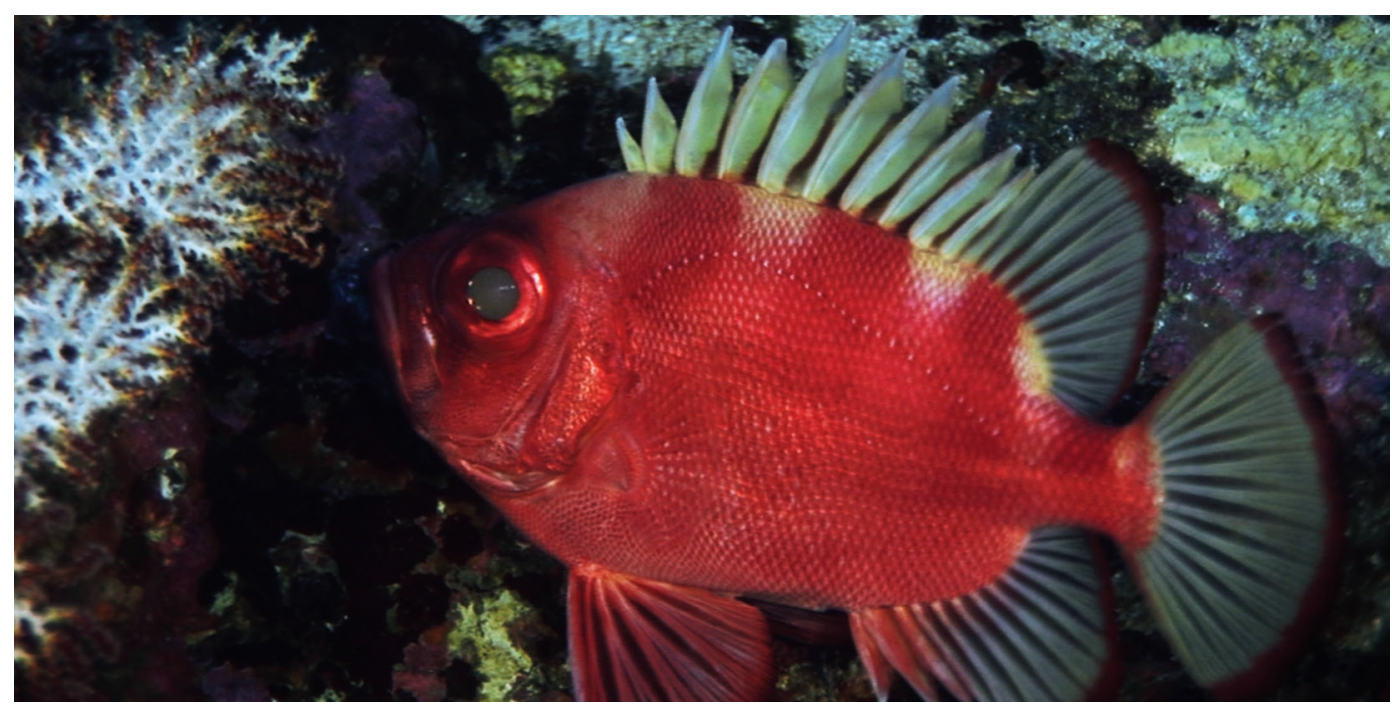

Pristigenys serrula at Everest (70 m), 1 September 2007, afternoon.

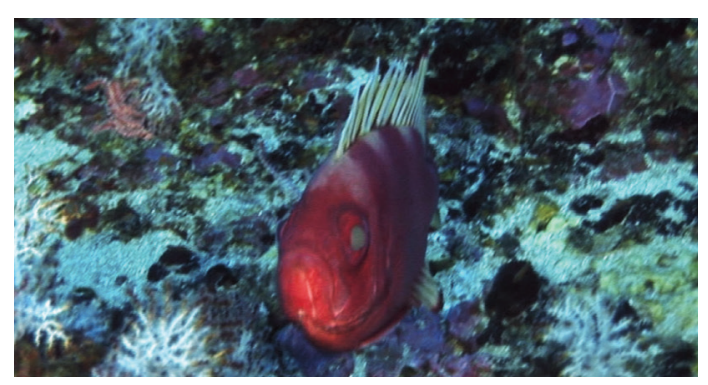

Pristigenys serrula at Everest (70 m), 1 September 2007, afternoon.

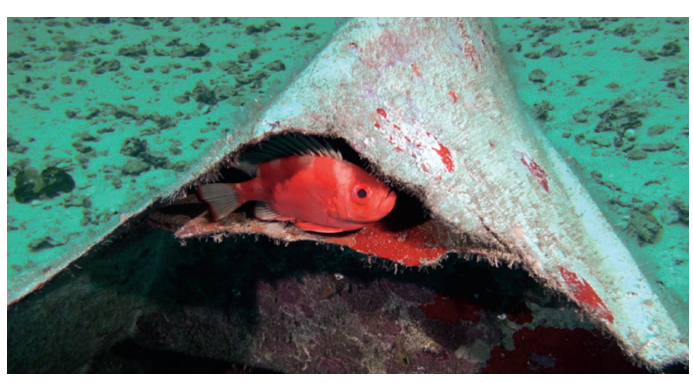

Pristigenys serrula at Bajo Manuelita $(60 \mathrm{~m})$, 1 July 2013, afternoon.

DESCRIPTION: Deep oval body, dark red including iris of eye, outer part of pelvic fins blackish (Robertson \& Allen, 2015), tail and soft parts of dorsal and anal fins with red-black margin. Large upturned mouth with a projecting lower jaw; preopercle without spine in adults; dorsal fin X, 11-12; anal III, 10-11; tail and pelvics rounded (Starnes, 1995; Robertson \& Allen, 2015). Grows to 33 $\mathrm{cm}$; young specimens with faint pale bars on sides (Robertson \& Allen, 2015). Depth: 3-250 m (Robertson \& Allen, 2015).

Worldwide Distribution: From central California to Chile, including Galápagos, Coco and Revillagigedo islands (Robertson \& Allen, 2015).

Occurrences at Isla del Coco (This study): 60-90 m, Bajo Manuelita (60 m), The Arch (60-90 m) and Everest $(70 \mathrm{~m})$ morning and afternoon.

Previous Reports From Isla Del Coco: Species reported by Garrison (2005), and by Fourriére et al. (2017). 


\section{Family Apogonidae}

Apogon atradorsatus Heller \& Snodgrass, 1903

Blacktip Cardinalfish / Cardenal aleta negra

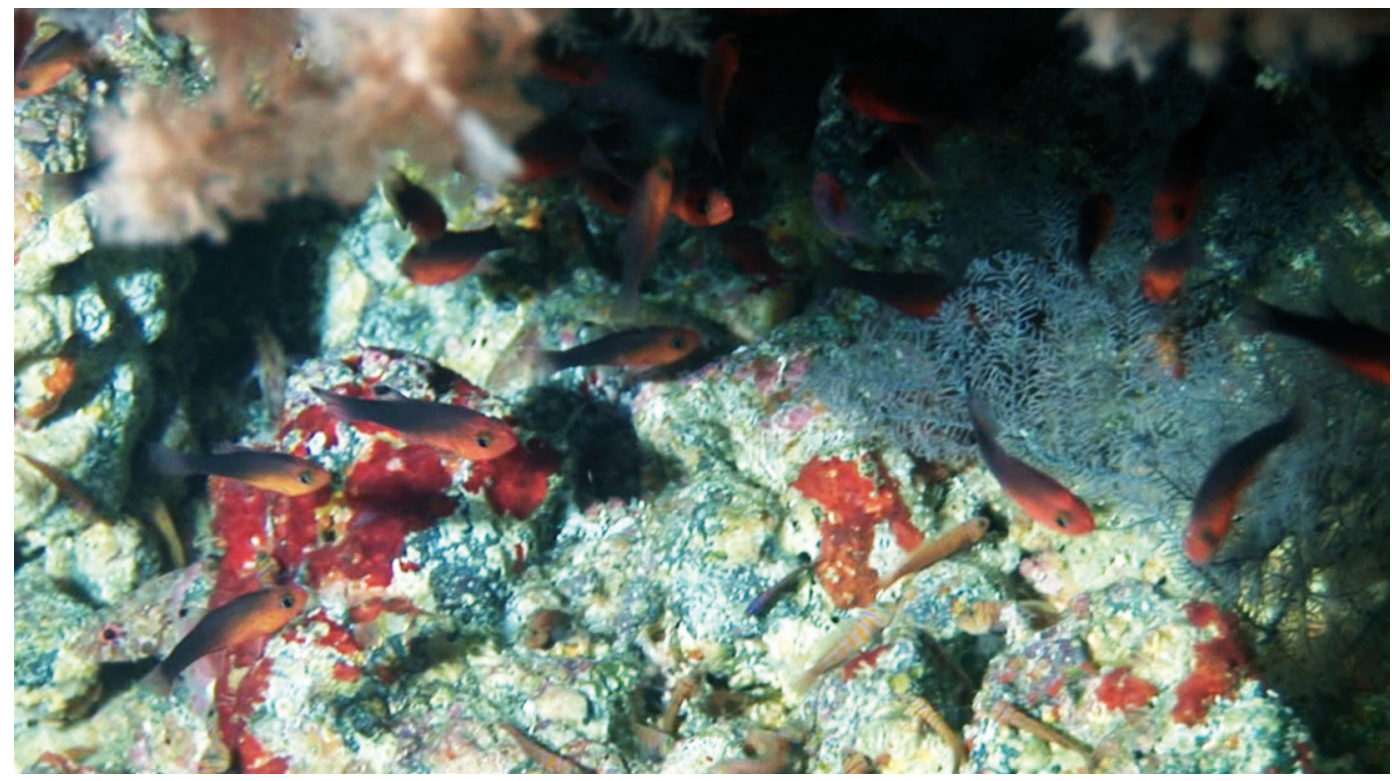

Apogon atradorsatus at Bajo Manuelita (40-50 m), 21 October 2010, morning.

DesCriPTIOn: Red-brown above, orange below. Tip of second dorsal fin with black spot. Grows to at least $13 \mathrm{~cm}$; depth: 3-45 m (Robertson \& Allen, 2015).

Worldwide Distribution: Galápagos, Coco and Malpelo islands (Robertson \& Allen, 2015).

Occurrences at Isla del Coco (This study): Frequent at Bajo Manuelita at 40-50 m.

Previous Reports From Isla del Coco: Reported by Garrison (2005), Friedlander et al. (2012), and Fourriére et al. (2017). 
Family Malacanthidae

Caulolatilus princeps (Jenyns, 1840)

Ocean Whitefish / Pierna o conejo

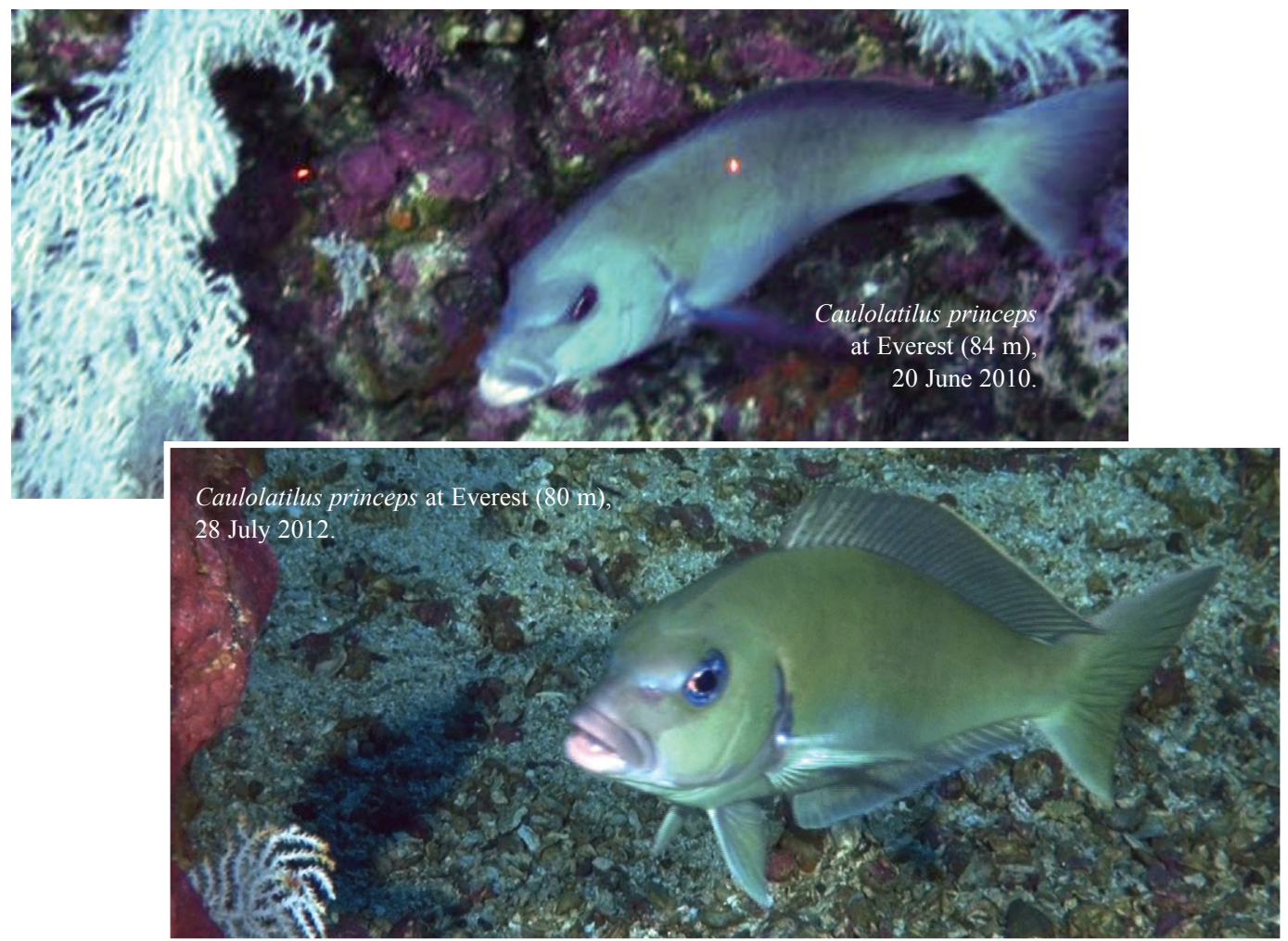

DESCRIPTION: Body robust, quadrangular; head relatively deep, snout profile relatively steep; mouth small reaching to front edge of eye (Schneider \& Krupp, 1995; Robertson \& Allen, 2015). Color generally light bluish grey, with a blue stripe along dorsal and anal fins; pectorals blue, with central yellow stripe (Robertson \& Allen, 2015). Size: $102 \mathrm{~cm}$. Depth range reported by Robertson and Allen (2015): 3-150 m.

Worldwide Distribution: Eastern Pacific, from British Columbia and Gulf of California to Chile, including the oceanic islands except Clipperton (Robertson \& Allen, 2015; Eschmeyer, Fricke, \& van der Laan, 2017).

Occurrences at Isla del Coco (This study): 80-160 m, Everest (80-85 m) and Piedra 165 (160 m), morning and afternoon.

Previous Reports from Isla del Coco: Species reported at Isla del Coco by Bussing and López (2005) and Fourriére et al. (2017).

Remarks: A similar species previously reported from Isla del Coco, C. hubbsi, was recently synonymized with $C$. princeps (Lea \& Feeney, 2016; Eschmeyer et al., 2017). Known maximum depth increased by $10 \mathrm{~m}$ to $160 \mathrm{~m}$. 


\section{Family Carangidae}

Caranx lugubris Poey, 1860

Black Jack / Jurel negro

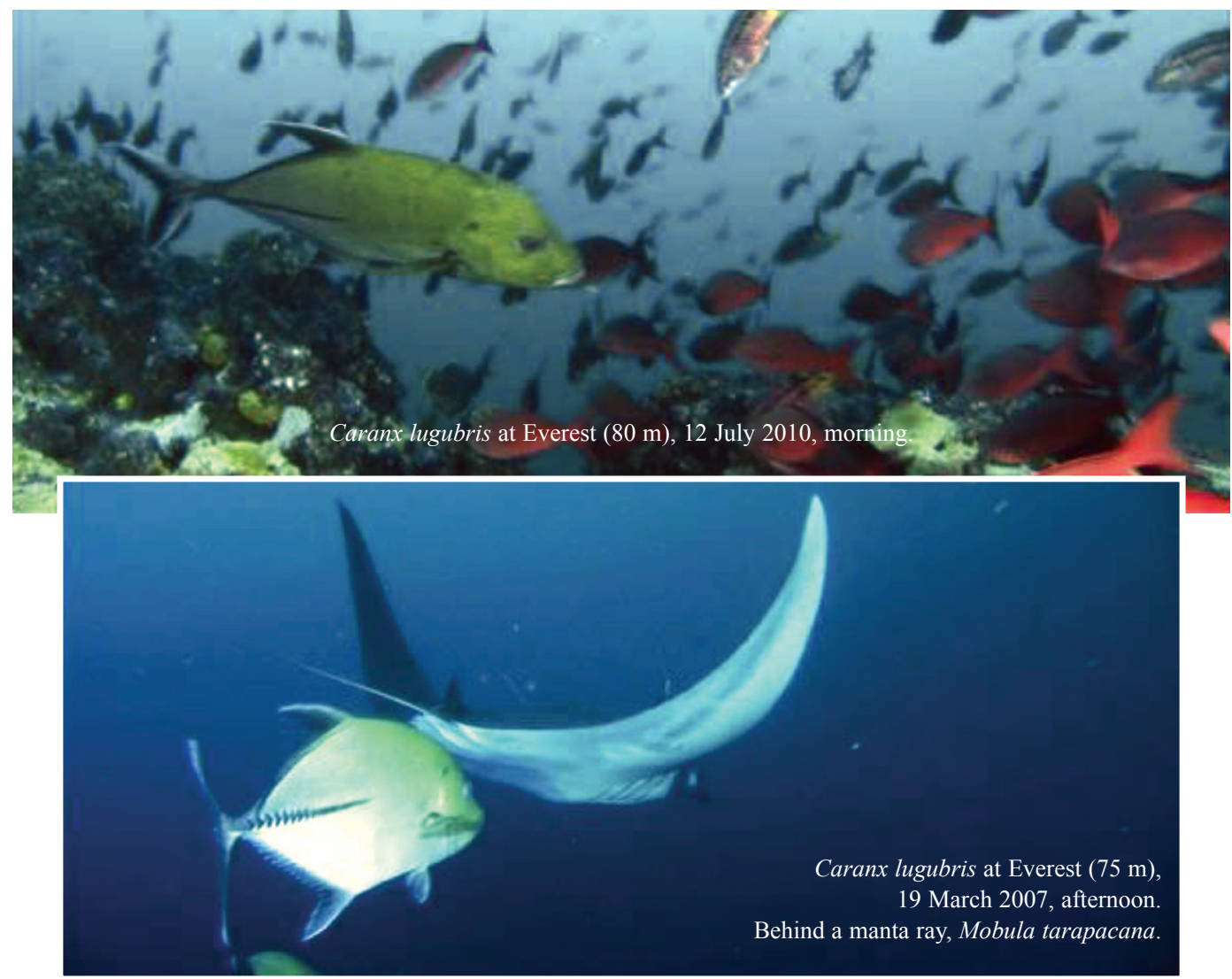

DesCriPtion: Body oblong, compressed (Smith-Vaniz, 1995). Head profile steep; a black dot on the upper edge of the operculum; second dorsal and anal fins elongated (Bussing \& López, 2005). Body mostly uniform grey, forked tail, narrow caudal peduncle (Garrison, 2005), scutes often black (Robertson \& Allen, 2015). Size: grows to $100 \mathrm{~cm}$. Depth: 3-380 m (Robertson \& Allen, 2015), usually 25-65 m (Smith-Vaniz, 1995).

Worldwide distribution: Circumtropical distribution (McCosker \& Rosenblatt, 2010). Eastern Pacific: southern Baja California and the mouth of the Gulf of California; all the offshore islands and Panamá (Robertson \& Allen, 2015).

Occurrences at Isla del Coco (This study): From the surface down to Everest $(75-86 \mathrm{~m})$, where it schools with other species; morning and afternoon.

Previous Reports from Isla del Coco: Bussing \& López (2005); in shallow waters at Roca Sucia, north of Manuelita and Roca Aleta de Tiburón (Garrison, 2005), and by Fourriére et al. (2017).

REMARKS: In deep waters recorded only at Everest. 


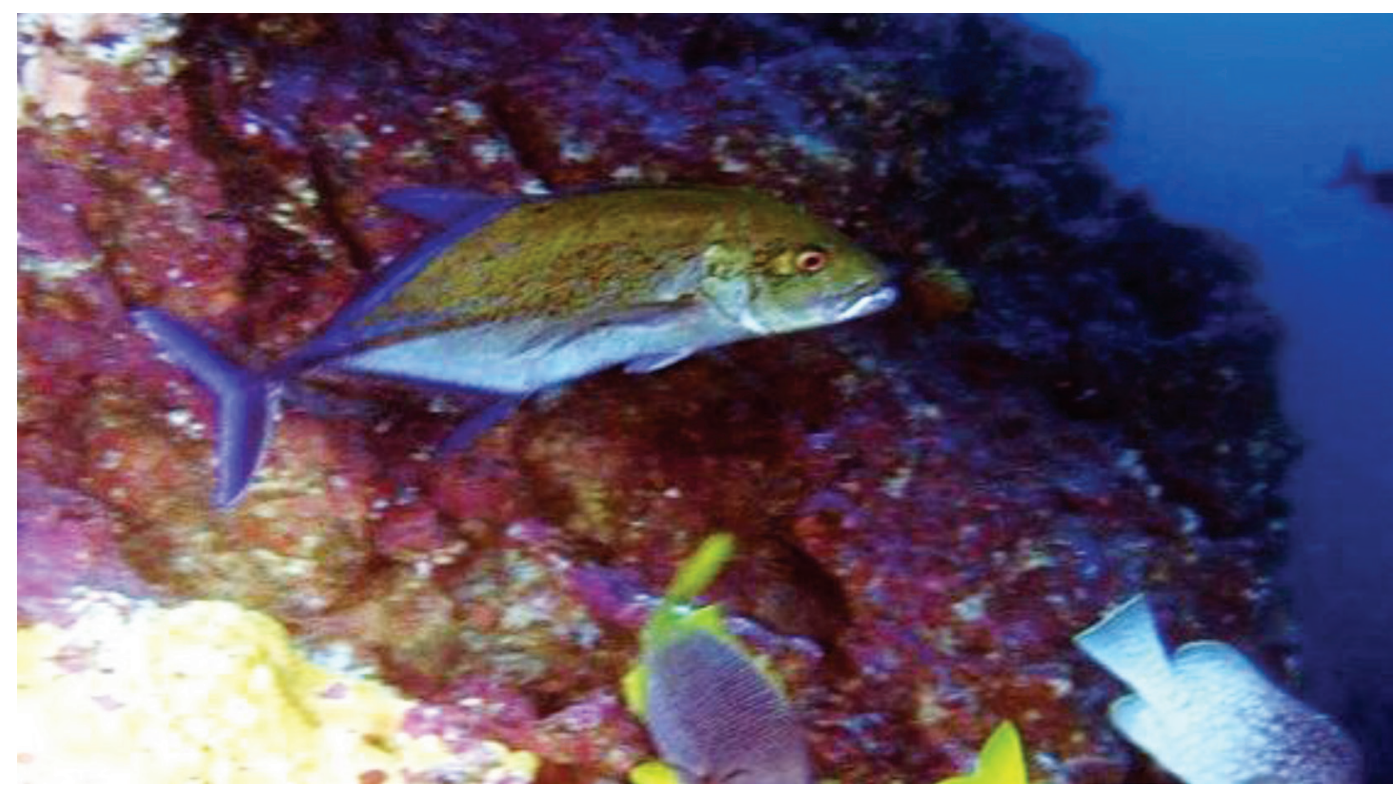

Caranx melampygus at Everest (86 m), 19 March 2007, afternoon.

DESCRIPTION: Body oblong, compressed. Adults with head and dorsal half of body brassy. In juvenile fish, body silver, yellow pectoral fins (Smith-Vaniz, 1995). Head and dorsal region with dark spots and fins electric blue except pectoral (Bussing \& López, 2005). Caudal peduncle narrow, forked tail (Garrison, 2005). Maximum size to $100 \mathrm{~cm}$ (Smith-Vaniz, 1995). Depth: 0-230 m (Robertson \& Allen, 2015).

Worldwide Distribution: Indo-Pacific from East Africa to the Americas; the tip of Baja California and the mouth of the Gulf of California; Costa Rica to Ecuador and the oceanic islands (Robertson \& Allen, 2015).

Occurrences at Isla del Coco (This Study): From the surface down to Everest $(86 \mathrm{~m})$ where it schools with other species; afternoon

Previous Reports from Isla del Coco: Bussing and López (2005), common in shallow waters (Garrison, 2005), and Fourriére et al. (2017).

REMARKs: In deep waters observed only at Everest, in the afternoon. 


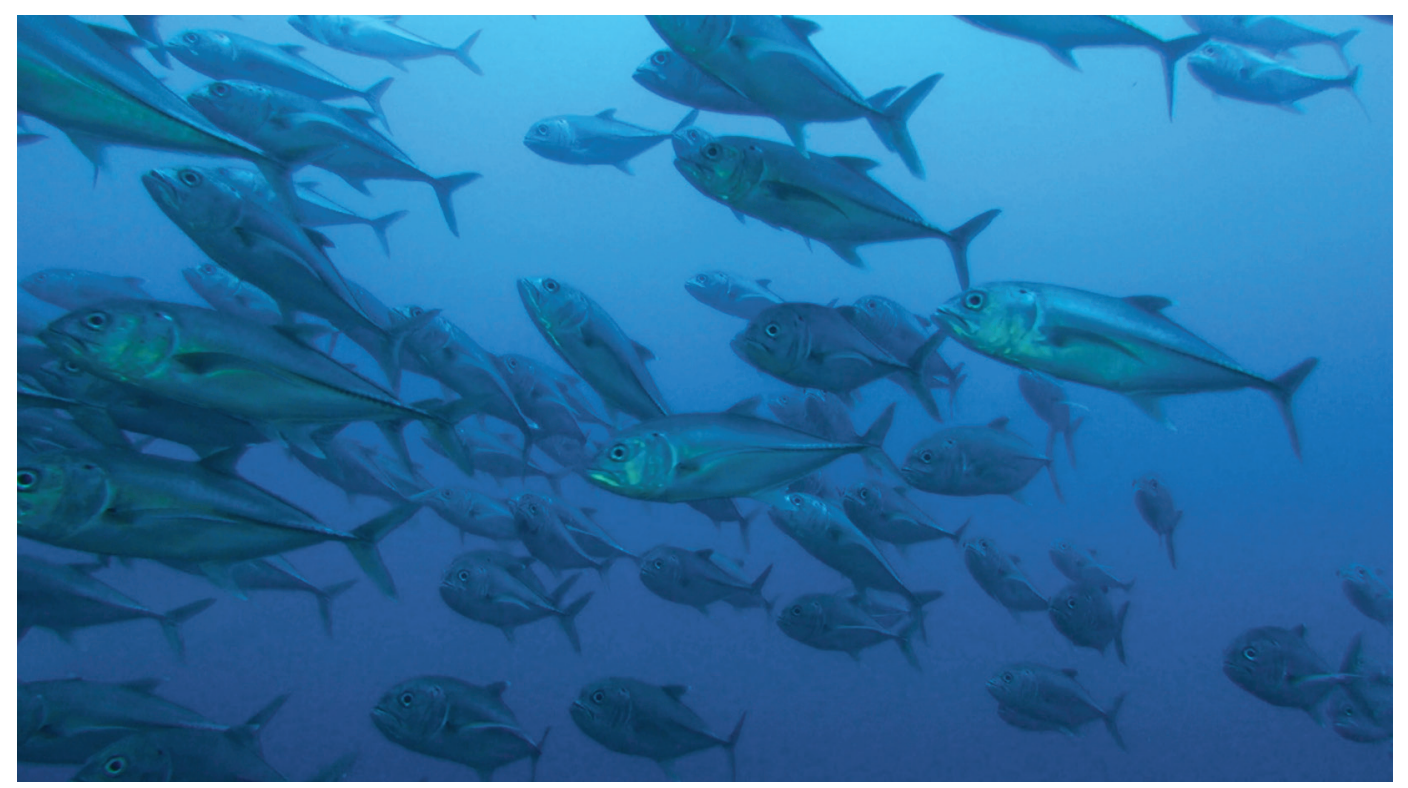

Caranx sexfasciatus at Everest (50 m), 13 July 2013.

DESCRIPTION: Body compressed; iridiscent blue green on back, shading to silvery white below; blackish spot near upper end of gill opening; white-tipped dorsal fin lobe. Size: reaches $120 \mathrm{~cm}$. Depth: 1-96 m (Robertson \& Allen, 2015).

Worldwide distribution: Indo-Pacific, Eastern Tropical Pacific (from southern California to the lower Gulf of California) to northern Perú and all the oceanic islands (Robertson \& Allen, 2015).

Occurrences at Isla del Coco (This study): From the surface down to Everest at $50 \mathrm{~m}$, in the afternoon.

Previous Reports from Isla del Coco: Reported in shallow waters at the island (Garrison, 2005; Bussing \& López, 2005), and Fourriére et al. (2017). 


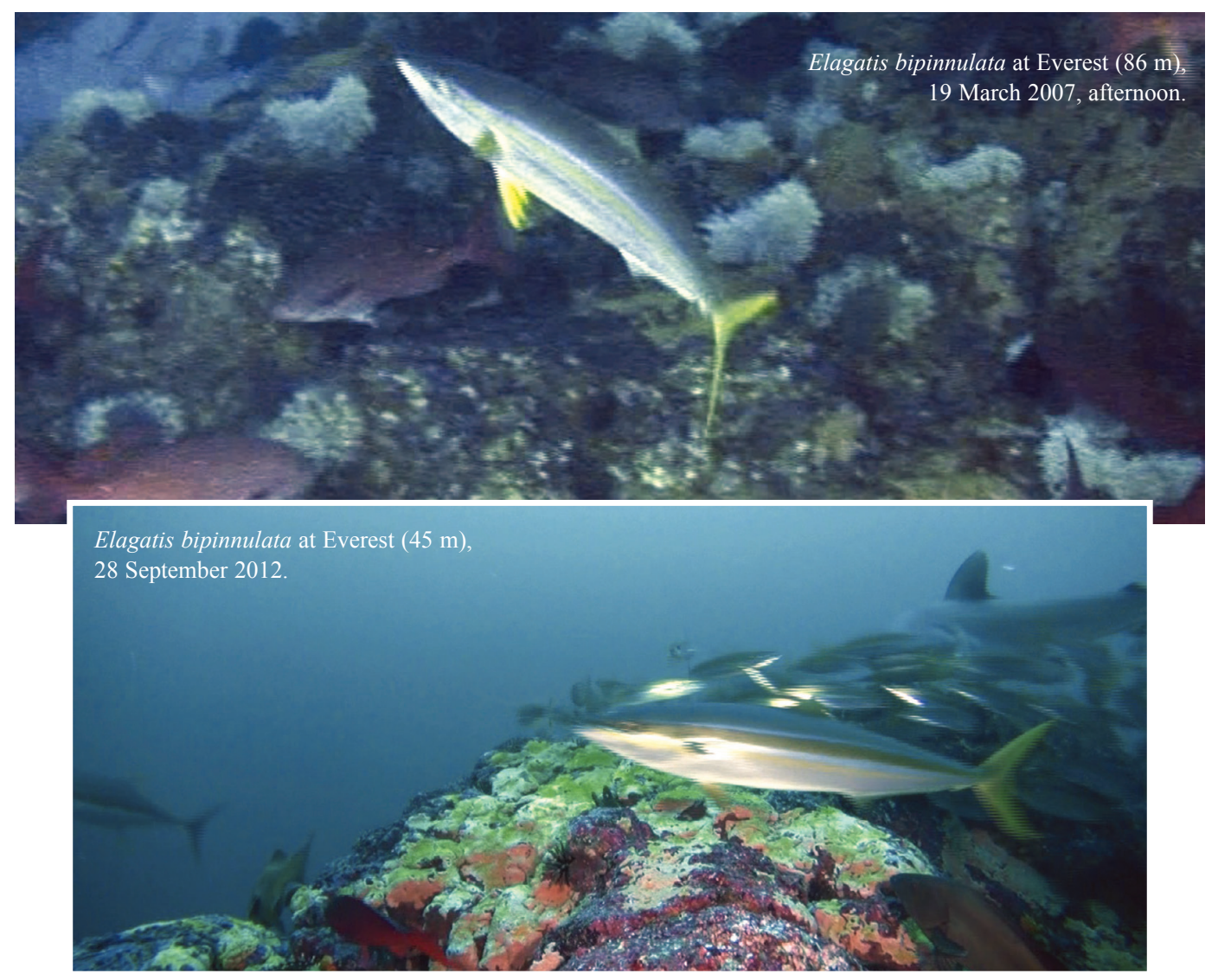

DesCRIPTION: Body elongate; dark olive green to blue above, white below (Garrison, 2005). Mouth small, snout pointed (Smith-Vaniz, 1995). Dorsal and anal fins each followed by a finlet with 2 rays (Bussing \& López, 2005). Fins with a yellow tint. Two narrow and light blue or bluish-white stripes along sides, with a broader olive or yellowish stripe between them. Size: grows to $180 \mathrm{~cm}$. Depth: 0-150 m (Myers, 1999).

Worldwide DISTRIBUTION: Circumtropical (Garrison, 2005; McCosker \& Rosenblatt, 2010); México to Panamá (López \& Bussing, 1982), Gulf of California to Ecuador and the Revillagigedo islands, Isla del Caño and Isla del Coco (Garrison, 2005).

Occurrences at Isla del Coco (This study): From the surface down to Everest (45-86 m), where they school with other species, in the afternoon.

Previous RePORTS From IsLa Del Coco: Bussing and López (2005); common in shallow waters (Garrison, 2005), and Fourriére et al. (2017).

REMARKS: In deep waters observed only at Everest, in the afternoon. 
Seriola rivoliana Valenciennes, 1833

Almaco Jack / Medregal limón u Hojarán

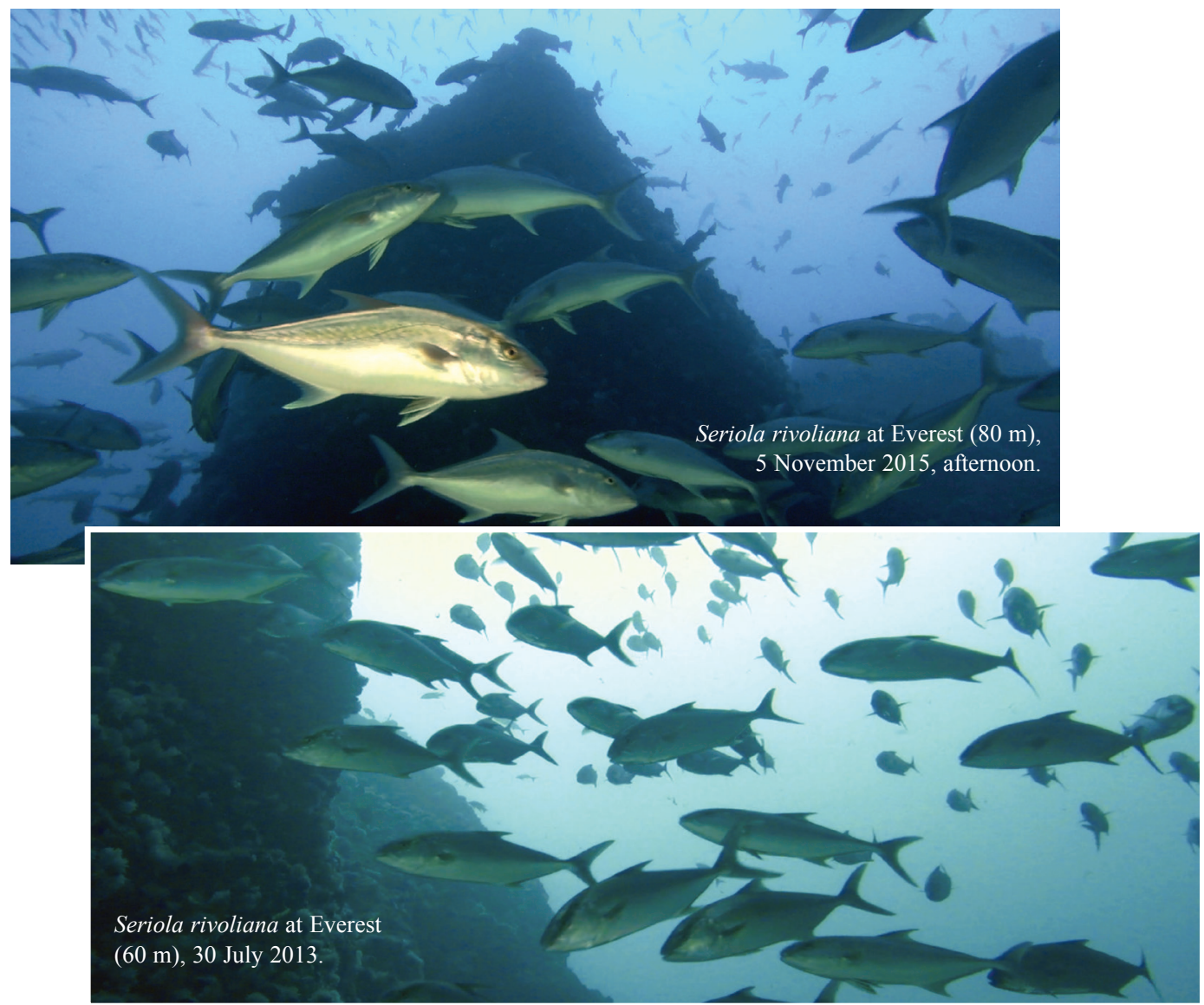

DesCRIPTION: Body high, compressed, snout pointed; bluish to greenish on upper back, silvery below (Robertson \& Allen, 2015). An oblique dark band between eye and origin of the first dorsal fin (Bussing \& López, 2005). Fins dark, white margin on ventral fins. Caudal peduncle narrow; tail forked (Garrison, 2005). Size: at least $157 \mathrm{~cm}$. Depth: 5-250 m (Robertson \& Allen, 2015), although rarely found at less than $30 \mathrm{~m}$ (Myers, 1999).

Worldwide Distribution: Circumtropical; in the Eastern Pacific from Southern California to the SW Gulf of California to Perú and the oceanic islands (Robertson \& Allen, 2015).

Occurences at Isla del Coco (This Study): Observed from $20 \mathrm{~m}$ when descending to Everest (50$90 \mathrm{~m})$, morning and afternoon.

Previous Reports from Isla del Coco: Bussing and López (2005), occasionally in shallow waters (Garrison, 2005), and Fourriére et al. (2017).

REMARKS: In deep waters observed only at Everest. 
Family Echeneidae

Remora remora (Linnaeus, 1758)

Remora / Rémora tiburonera

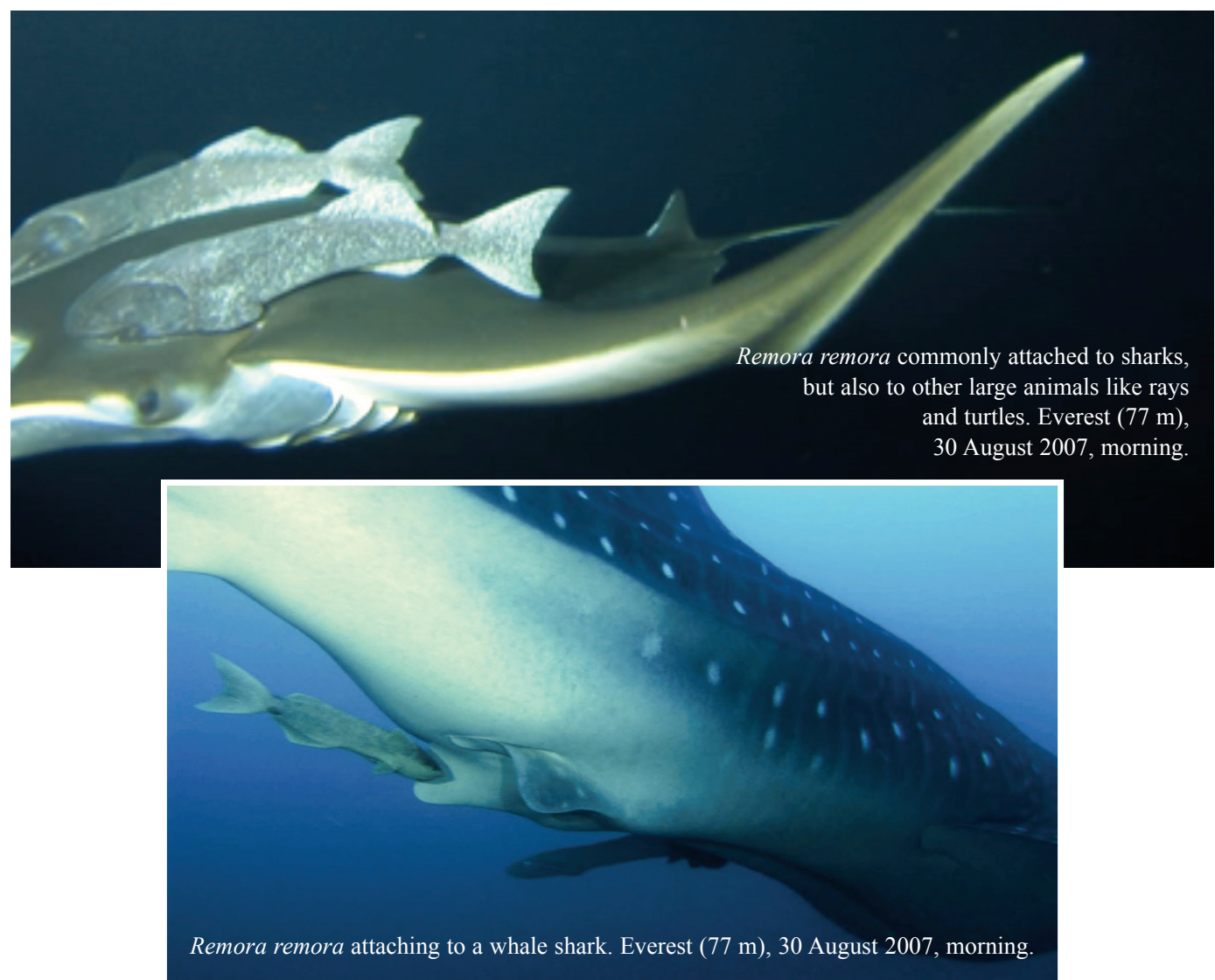

DesCriPTIOn: Robust, flat head; caudal peduncle thick (Paulin \& Habib, 1982). Elongate, light gray to slate gray (Robertson \& Allen 2015). Sucking disk with 16-20 laminae reaches to about end of pectoral fins (Schneider, 1995; Bussing \& López, 2005). Size to $86 \mathrm{~cm}$. Depth: 0-200 m (Robertson $\&$ Allen, 2015), recorded at more than $50 \mathrm{~m}$ at Isla del Coco (Starr et al., 2012b).

Worldwide Distribution: Circumtropical (Paulin \& Habib, 1982; McCosker \& Rosenblatt, 2010; Robertson \& Allen, 2015); throughout the Eastern Tropical Pacific, except for the upper Gulf of California (Robertson \& Allen, 2015).

Occurrences at Isla del Coco (This study): 45-300 m; Everest (45-90 m), morning; Piedra 165 (150-170 m) afternoon. Observed down to $300 \mathrm{~m}$ deep.

Previous reports from Isla del Coco: Occasionally in shallow waters (Bussing \& López, 2005; Garrison, 2005). Starr et al. (2012b) recorded the species at more than $50 \mathrm{~m}$ at Isla del Coco and at Las Gemelas Seamount. Reported by Fourriére et al. (2017) as a deep-water species.

REMARKs: Extends the previous depth record $100 \mathrm{~m}$ deeper to $300 \mathrm{~m}$. 
Family Lutjanidae

Lutjanus aratus (Günther, 1864)

Mullet Snapper / Pargo raicero

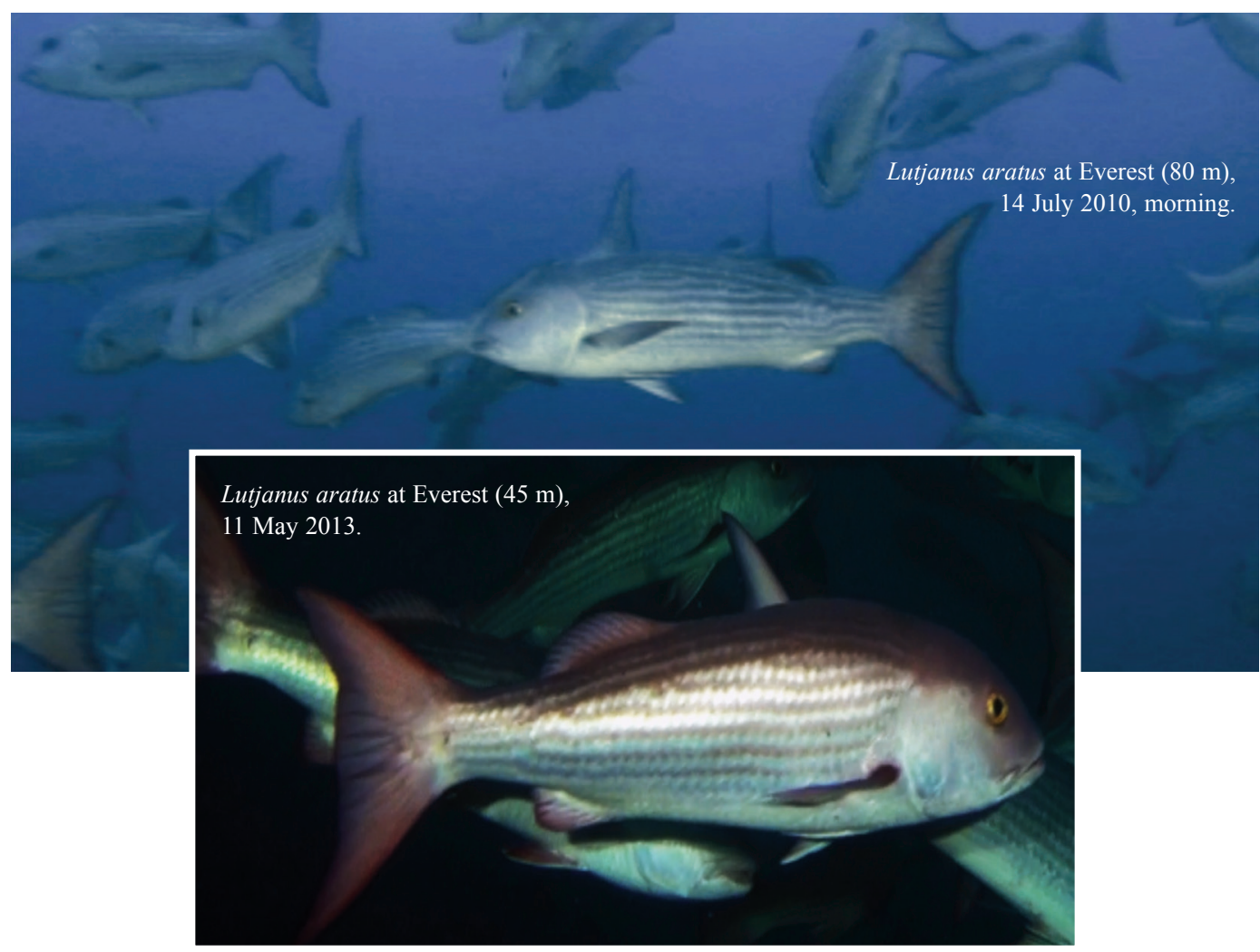

DesCRIPTIOn: Greenish-grey above, pink below. Fins grey, pelvic and pectoral translucid pink. Fish from deeper water mostly reddish (Allen, 1995). Dark spot located at the base of the pectoral fins, center of each scale whitish (Allen, 1995) forming alternating dark and light stripes along sides (Bussing \& López, 2005). Eyes yellow (Garrison, 2005). Size: reaches about $100 \mathrm{~cm}$. Depth: 0-60 $\mathrm{m}$. Individual captured with hand line for commercial purposes at approximately $50 \mathrm{~m}$ (Allen, 1995), same maximum depth reported by Robertson and Allen (2015); reported at $60 \mathrm{~m}$ by JiménezPrado and Béarez (2004).

Worldwide Distribution: Eastern Pacific (Allen, 1995), Gulf of California to Ecuador (López \& Bussing, 1982), Malpelo, Galápagos Islands and Isla de Coco (Robertson \& Allen, 2015).

Occurrences at Isla del Coco (This Study): 45-80 m; Everest (45-80 m), morning and afternoon; Bajo Manuelita (62 m), afternoon.

Previous RePorts from Isla del Coco: Bussing and López (2005) report the species in shallow waters at Roca Sucia, Dos Amigos Grande, Manuelita, Roca Aleta de Tiburón and Roca Sumergida; Garrison (2005) at Viking Rock (Isla Cáscara), and by Fourriére et al. (2017).

REMARKs: Known maximum depth increased by $20 \mathrm{~m}$. 


\section{Family Haemulidae}

Anisotremus interruptus (Gill, 1862)

Burrito Grunt / Burro bacoco

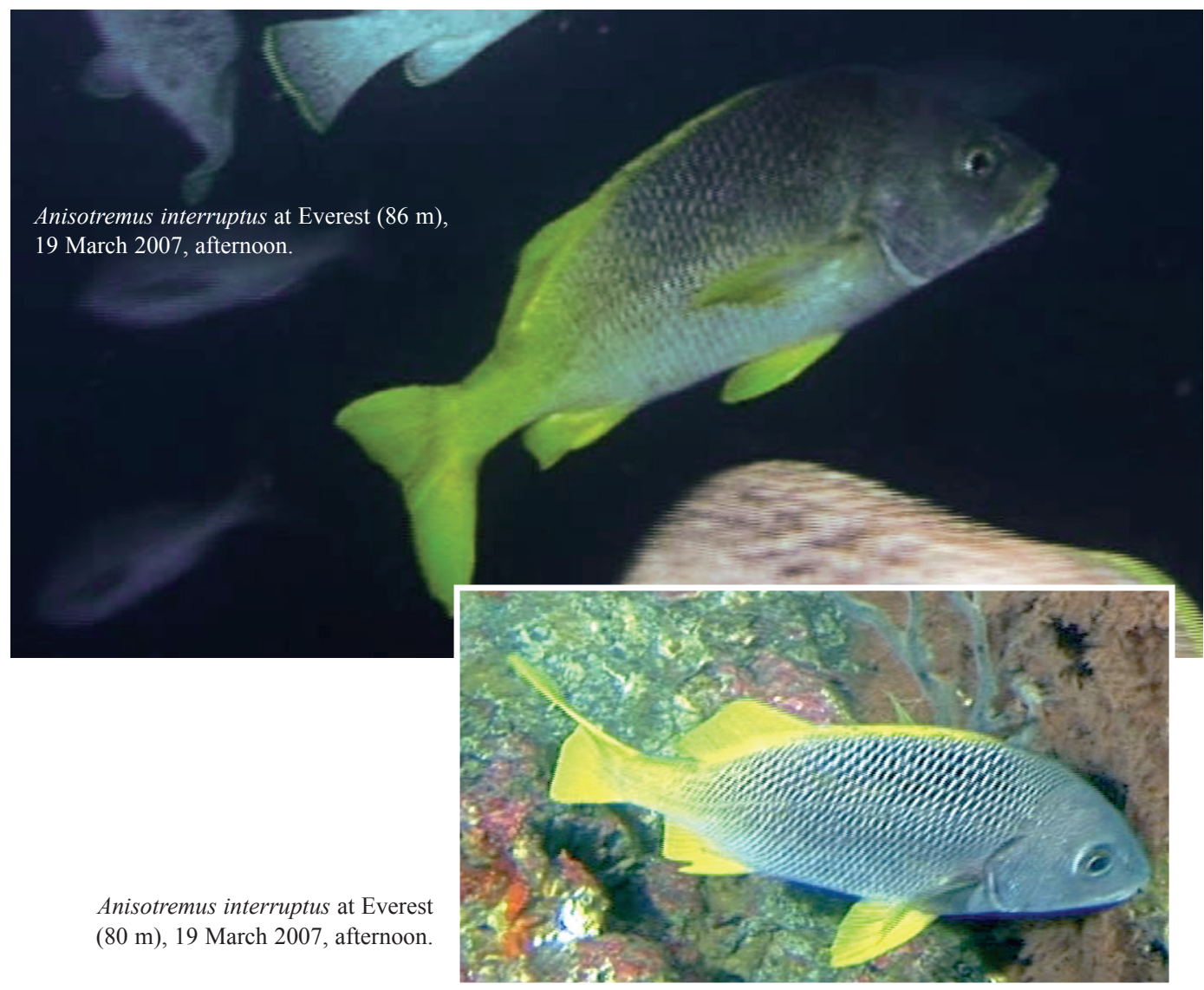

DeSCRIPTIOn: Body deep, compressed, silver dorsal side. Large scales above lateral line with a dark anterior border in oblique rows; fins greenish yellow (McKay \& Schneider, 1995); pectoral fins long (Bussing \& López, 2005). Maximum length, $90 \mathrm{~cm}$. Depth: 3-30 m (Humann \& Deloach, 1993; Robertson \& Allen, 2015).

Worldwide distribution: Eastern Pacific (McCosker \& Rosenblatt, 2010). Gulf of California to Perú, including all the oceanic islands, except Clipperton (Robertson \& Allen, 2015).

Occurrences at Isla del Coco (This study): 20-90 m, from the initial stage of descent to Everest (86-90 m), morning and afternoon; and Bajo Manuelita (65 m), afternoon.

Previous Reports from Isla del Coco: Bussing and López (2005), from common to occasional in shallow waters (Garrison, 2005) and by Fourriére et al. (2017).

REMARKs: No published reports from deep waters for this species; depth reported in shallow waters by Humann and Deloach (1993), extended here from $30 \mathrm{~m}$ to $90 \mathrm{~m}$. 


\section{Family Mullidae}

Mulloidichthys cf. dentatus (Gill, 1862)

Mexican Goatfish / Chivo barbón

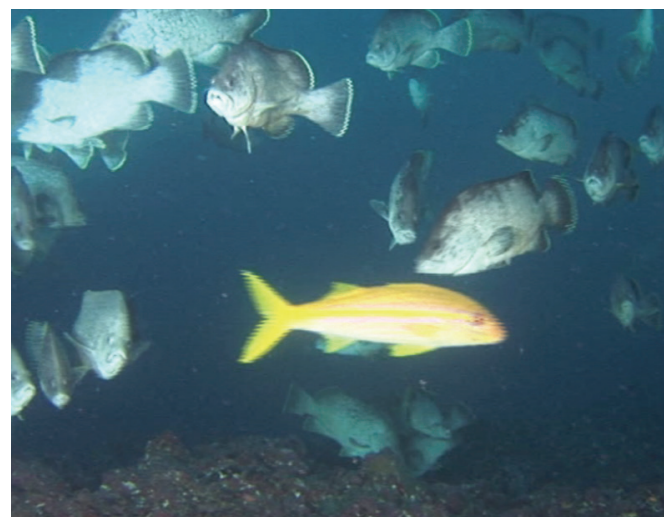

Mulloidichthys cf. dentatus at Everest (45 m), 28 April 2009, afternoon.

Mulloidichthys cf. dentatus at the top of Everest (45 m), 28 April 2009, afternoon.

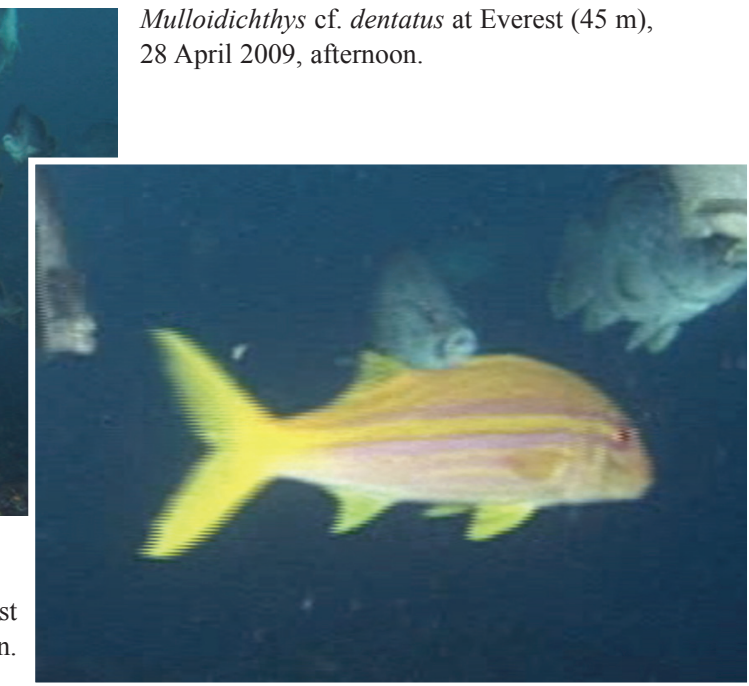

DesCriPTIOn: Both $M$. dentatus and M. vanicolensis have elongate, cylindrical bodies; underside of head and body nearly flat; mouth small; chin with a pair of large, long barbels; two dorsal fins; yellow to greenish yellow on back and top of head, whitish on lower parts; a broad bright yellow midlateral stripe with a thinner bluish stripe immediately above; tail fin bright yellow (Robertson $\&$ Allen, 2015). These species are very similar, which makes it difficult to distinguish them based on the photographs. Mulloidichthys vanicolensis differs from $M$. dentatus in having more pectoral fin rays, a slightly longer pectoral fin, slightly longer barbels and more gill-rakers (Robertson \& Allen, 2015). These differences are so slight that in practice it is probably not possible to separate all individuals of the two species when they are together at the same location (Robertson \& Allen, 2015). Mulloidichthys dentatus reaches $40 \mathrm{~cm}$, and M. vanicolensis $31 \mathrm{~cm}$ (Robertson \& Allen, 2015). Depth range known for both species: 2-110 m (Robertson \& Allen, 2015).

Worldwide Distribution: Mulloidichthys dentatus: Eastern Pacific (McCosker \& Rosenblatt, 2010), from southern Baja and the Gulf of California to the north of Perú, including the outer islands of Revillagigedo, Galápagos, Malpelo and Isla del Coco (Robertson \& Allen, 2015). Mulloidichthys vanicolensis is widespread throughout the Indo-Pacific, but it also can be found in the Eastern Tropical Pacific (Lessios \& Robertson, 2013; Robertson \& Allen, 2015).

Occurrences at Isla del Coco (This study): Surface down to $60 \mathrm{~m}$, on the way to Everest.

Previous Reports from Isla Del Coco: Mulloidichthys dentatus reported by Bussing and López (2005) and Robertson and Allen (2015).

Remarks: $M$. vanicolensis was until recently believed to be limited to the Indo-Pacific and the Central Pacific (Randall, 2005), but it has now been confirmed to exist on the American coast (Robertson, Grove, \& McCosker, 2004; Lessios \& Robertson, 2006, 2013). 


\section{Family Chaetodontidae}

Johnrandallia nigrirostris (Gill, 1862)

Barberfish / Mariposa barbero

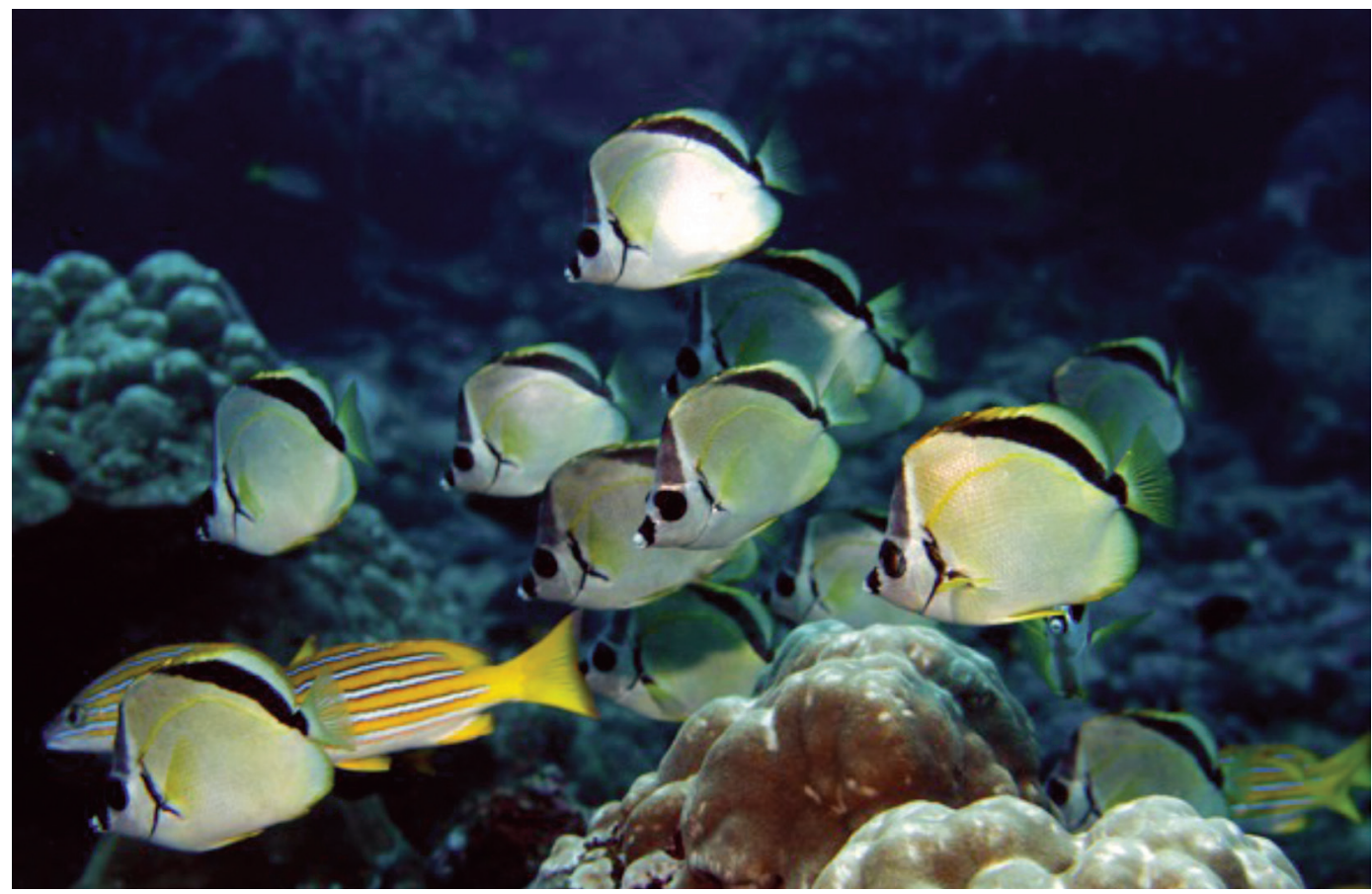

Johnrandallia nigrirostris in shallow waters at Isla del Coco. Photograph by Avi Klapfer.

Description: Body and fins yellow. Oblique black band from spinous dorsal fin to tail base (Bussing \& López, 2005; Garrison, 2005). Eye and operculum bordered with black. Body compressed, disk-shaped. Mouth small and protrusible (Garrison, 2005). Dorsal fin with XII spines, 4th spine the longest. Maximum size: $20 \mathrm{~cm}$. Depth: 5-40 m, common between 6-12 m (Schneider, 1995).

Worldwide Distribution: Central Baja to the central Gulf of California to central Perú and all the Eastern Tropical Pacific oceanic islands (Garrison, 2005).

Occurrences at Isla del Coco (This study): Bajo Manuelita $(40 \mathrm{~m})$ and at the summit of Everest (45 $\mathrm{m}$ ) down to $50 \mathrm{~m}$, afternoon.

Previous Reports from Isla del Coco: Reported by Garrison (2005) and Fourriére et al. (2017).

ReMARKs: Known depth range expanded from 40 to $50 \mathrm{~m}$.

NotE: The images available from the deep waters are of very poor quality, reason why we use this shallow water photograph. 


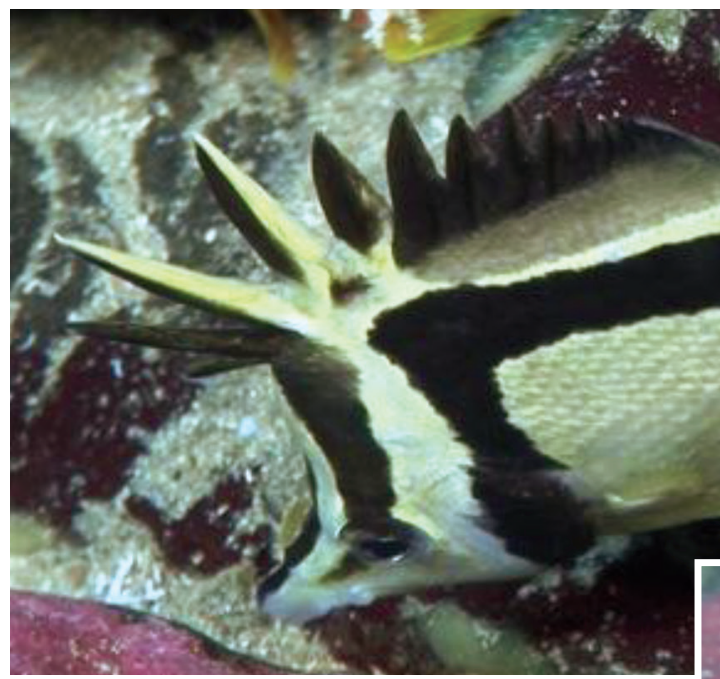

Prognathodes carlhubbsi at The Arch (90 m), 22 February 2007, morning.

Prognathodes carlhubbsi at The Arch (90 m), 22 February 2007, morning.

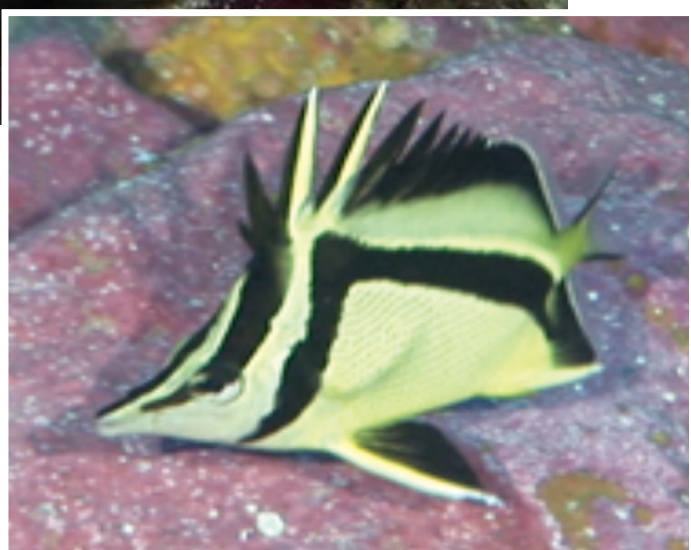

DESCRIPTION: Body high, well compressed, yellowish. Head rhomboid, with a relatively long and pointed snout. Orbit large (Nalbant, 1995). Dorsal spines, 2nd anal spine very long. Body with two dark bands, an inverted black "V" and a black band from snout to first dorsal spine. The ventral fins are black except 1st spine and ray (Hooker, 2009). Size: grows to $12 \mathrm{~cm}$. Depth: 12-270 m (Robertson \& Allen, 2015), possibly at an optimum of 75-100 m (Nalbant, 1995).

Worldwide Distribution: Galápagos Islands, Isla del Coco and Malpelo (Robertson \& Allen, 2015) and Islas Lobos de Afuera, Perú (Hooker, 2009).

Occurrences at Isla del Coco (This study): 90-150 m, Everest (70 m), The Arch (90 m) and deeper areas close by, morning and afternoon.

Previous RePORTS FROM IsLA Del Coco: Reported by Fourriére et al. (2017)

Remarks: McCosker and Rosenblatt (2010) consider P. carlhubbsi to be a junior synonym of P. falcifer (Hubbs \& Rechnitzer, 1958). Depth range possibly limited by diet, composed mainly of coral polyps and other benthic invertebrates, especially crustaceans and polychate worms (Nalbant, 1995). 


\section{Family Pomacanthidae}

Holacanthus passer Valenciennes, 1846

King Angelfish / Ángel real

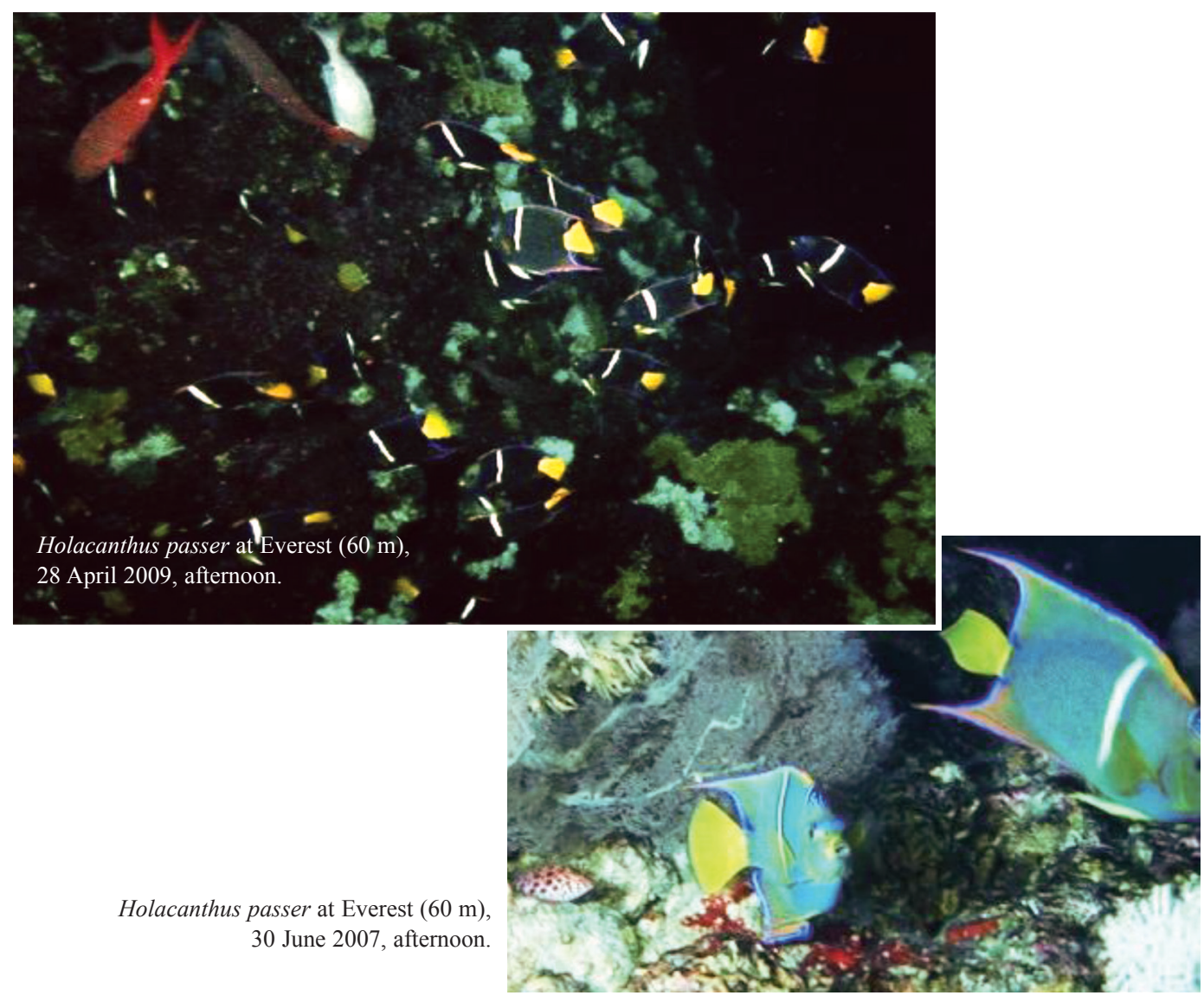

DesCRIPTION: Deep compressed body, small mouth (Robertson \& Allen, 2015). Blueish green with a white transverse band (Krupp \& Schneider, 1995), from the base of the dorsal fin to the back of the pectoral fin (Bussing \& López, 2005). Tail fin yellow or orange. Juveniles reddishbrown, blue stripes, pectoral band and tail fin deep orange (Krupp \& Schneider, 1995). Maximum length approximately $36 \mathrm{~cm}$ Depth range: 1-80 m (Aburto-Oropeza \& Balart-Páez, 2001; Robertson \& Allen, 2015).

Worldwide Distribution: Eastern Pacific (McCosker \& Rosenblatt, 2010). Central Baja California and Gulf of California to northern Perú, including the Revillagigedo, Galápagos, Malpelo and Coco islands (Robertson \& Allen, 2015).

Occurrences at Isla del Coco (This study): On the way and at Everest (20-60 m) morning and afternoon.

Previous Reports from Isla del Coco: Common in shallow waters down to approximately $42 \mathrm{~m}$ (Garrison, 2005), and Fourriére et al. (2017). 


\section{Family Cirrhitidae}

Cirrhitichthys oxycephalus (Bleeker, 1855)

Coral Hawkfish / Halcón de coral

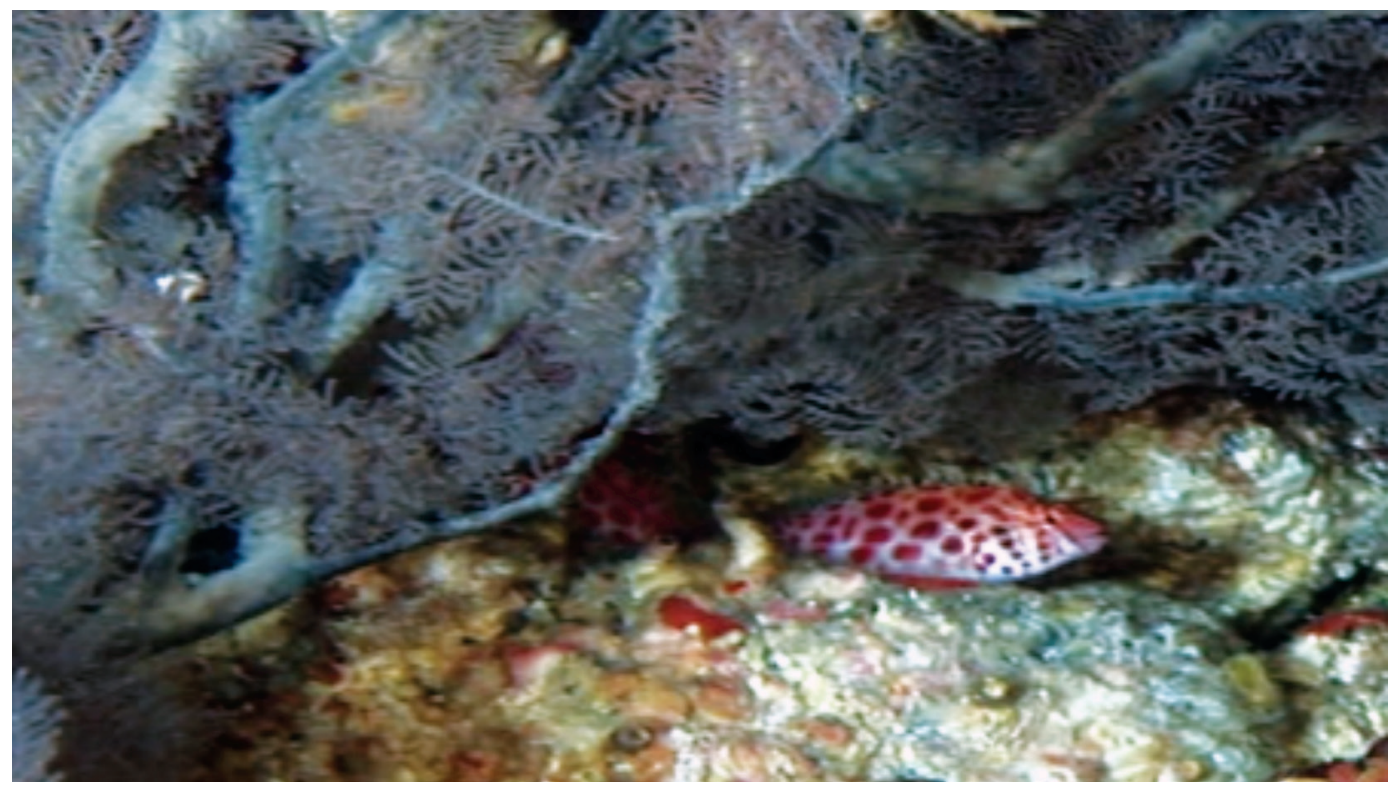

Cirrhitichthys oxycephalus at Bajo Manuelita (65 m), 30 June 2007, afternoon, under a black coral.

DESCRIPTION: Whitish or pinkish body with reddish brown spots, margined in red (Bussing \& López, 2005), shading to white ventrally, with a fringe of cirri at the tips of dorsal fin spines (Garrison, 2005). Body oval; snout pointed. Size: grows to $10 \mathrm{~cm}$. Depth: 2-40 m (Myers, 1999; Bussing \& Lavenberg, 1995a).

Worldwide distribution: Tropical Indo-Pacific and Eastern Pacific (Randall, Allen \& Steene, 1990), from the Gulf of California and Cabo San Lucas to northern Peru, including Gorgona and the Galápagos Islands (Bussing \& Lavenberg, 1995a).

Occurrences at Isla del Coco (This study): 40-65 m, Bajo Manuelita (40-60 m), the summit of Everest $(45 \mathrm{~m})$ and down to $65 \mathrm{~m}$; afternoon.

Previous Reports from Isla del Coco: Bussing and López (2005), common in shallow waters down to $36 \mathrm{~m}$ (Garrison, 2005), and Fourriére et al. (2017).

REMARKS: Observed $25 \mathrm{~m}$ deeper than reported previously, down to $65 \mathrm{~m}$. 


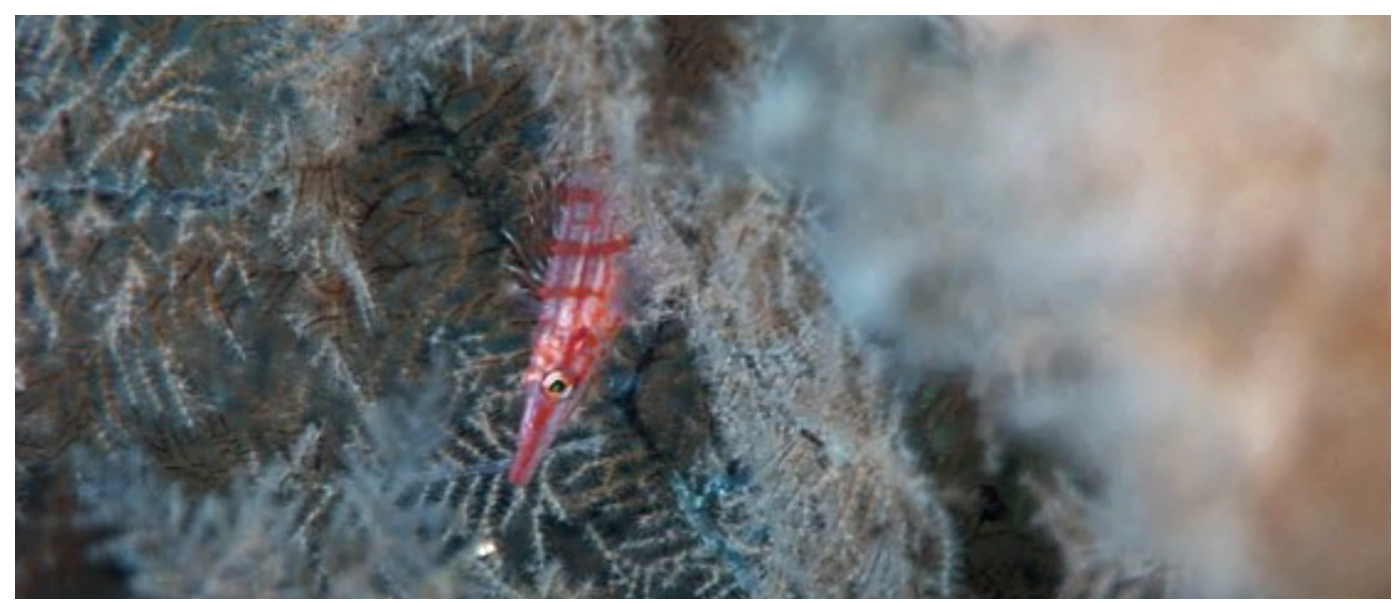

Oxycirrhites typus within black coral and gorgonians, at Everest (84 m), 20 June 2010, morning.

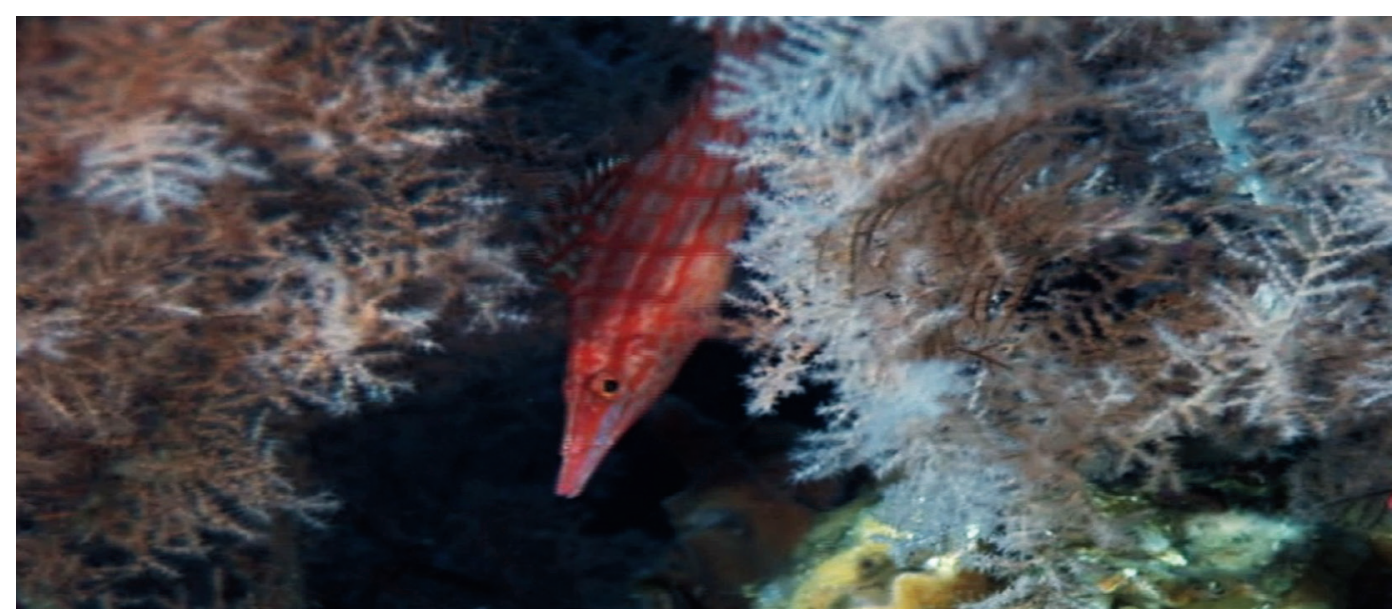

Oxycirrhites typus within black coral and gorgonians, at Everest (84 m), 20 June 2010, morning.

DesCRIPTION: Long-snouted fish with horizontal and vertical red bands (Bussing \& López, 2005), forming a cross-hatch pattern. Dorsal spines with 2-4 cirri near the tip (Randall et al., 1990). Size to $13 \mathrm{~cm}$. Depth: 5-100 m (Bussing \& Lavenberg, 1995a).

Worldwide Distribution: Indo-Pacific and Eastern Pacific (Randall et al., 1990), Gulf of California, from Cabo San Lucas to Guaymas, (Bussing \& Lavenberg, 1995a), Isla del Coco, Galápagos, Revillagigedo and Malpelo Islands (Robertson \& Allen, 2015).

OCCurRences at Isla del Coco (This Study): Everest at $84 \mathrm{~m}$, in the morning.

Previous Reports from Isla del Coco: Bussing and López (2005) and Fourriére et al. (2017). 


\section{Family Pomacentridae}

Chromis alta Greenfield \&Woods, 1980

Silverstripe Chromis / Castañeta alta

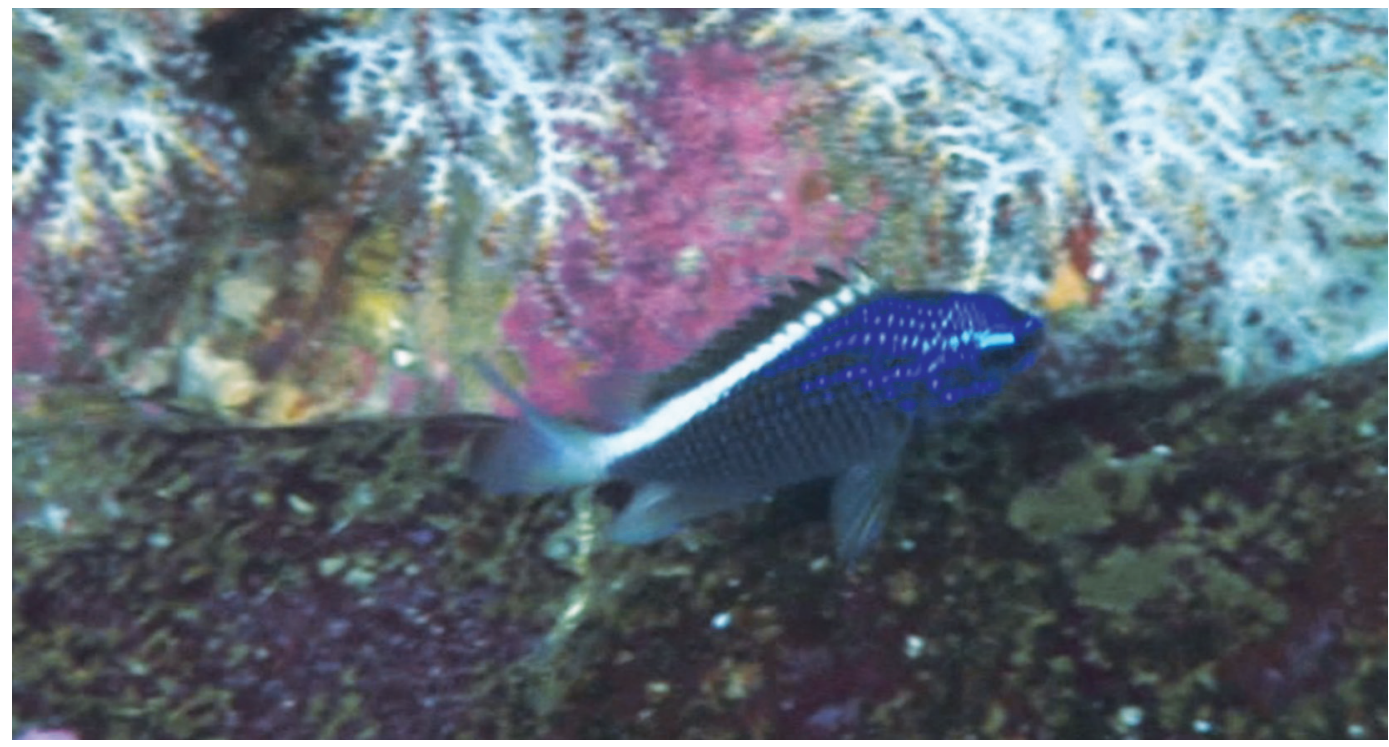

Chromis alta, juvenile at Everest (80 m), 28 April 2009, afternoon.

DESCRIPTION: Deep oval compressed body. Adults overall light brown with darker scale margins; juveniles blue with neon-blue stripe above and below eye, and broad withish band along base of dorsal fin that joins diffuse pale bar across tail base (Bussing \& López, 2005; Robertson \& Allen, 2015). Depth: 1-200 m (Robertson \& Allen, 2015).

Worldwide distribution: Southern California to southern México, all the Eastern Tropical Pacific offshore islands, to Lobos de Afuera islands off Perú (Robertson \& Allen, 2015).

Occurrences at Isla del Coco Coco (This study): At the base of Everest (80-90 m), morning.

Previous reports from Isla del Coco: Bussing and López (2005) and Fourriére et al. (2017). 


\section{Family Labridae}

Bodianus diplotaenia (Gill, 1862)

Mexican Hogfish / Vieja mexicana

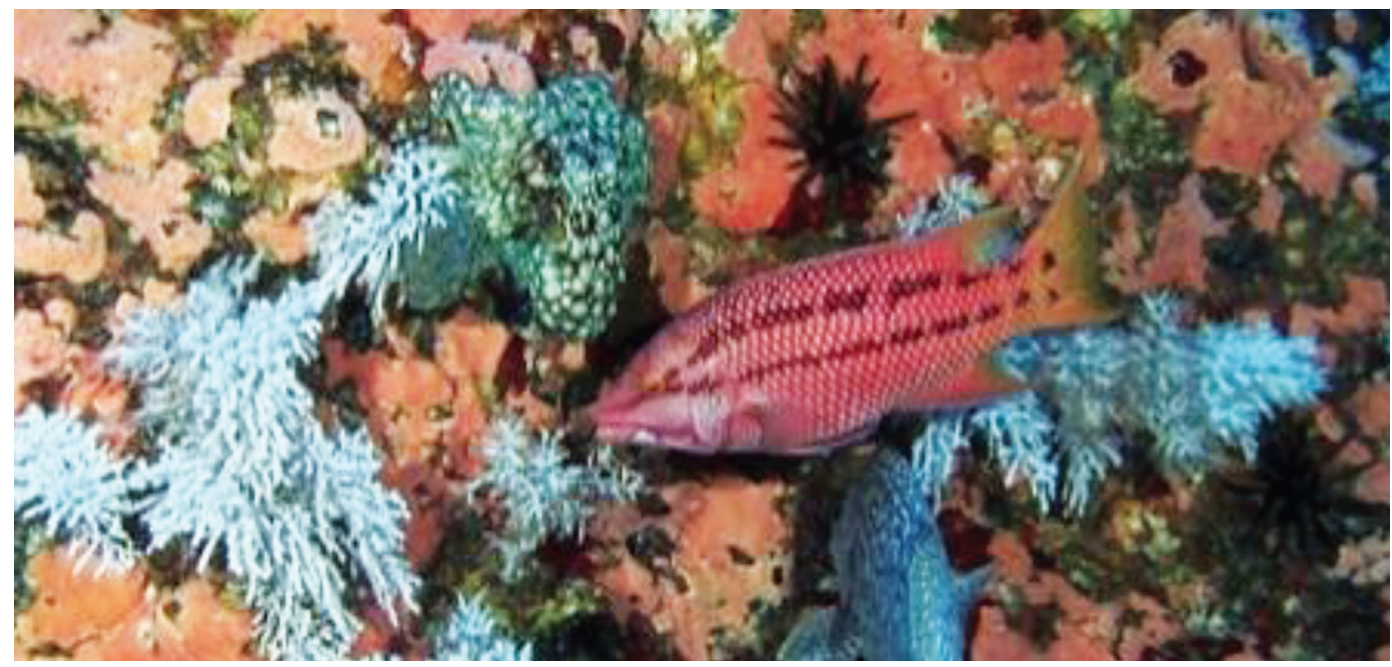

A juvenil of Bodianus diplotaenia start life as a female, then matures into a male and changes its colors. At Everest (80 m), 13 December 2009, afternoon.
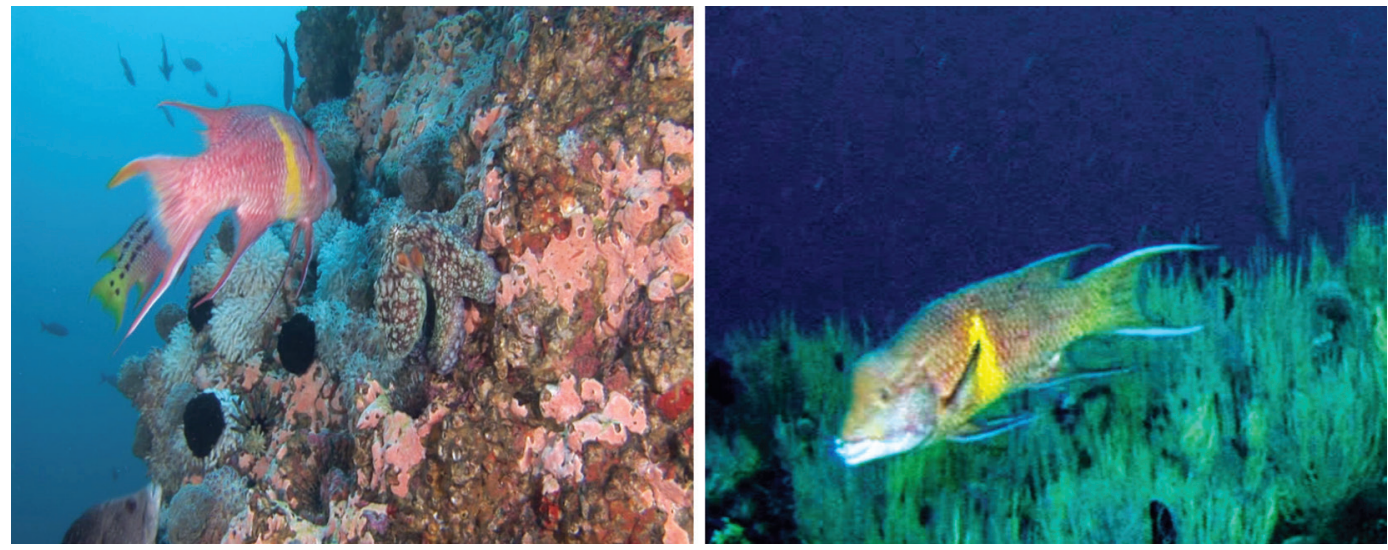

Bodianus diplotaenia, adult at Everest ( 85 m), 22 December 2007 (left) and at The Arch $(80 \mathrm{~m}), 15$ January 2008, afternoon (right).

DeSCRIPTIOn: Moderately deep and compressed; head large, snout pointed. Adult males greyish with a yellow band immediately behind posterior edge of pectoral. Female and juveniles reddish with two longitudinal dark broken stripes (Gomon, 1995; Bussing \& López, 2005). Hump between eyes and lateral line somewhat arched. Maximum size: $76 \mathrm{~cm}$. Depth: shallow waters to $76 \mathrm{~m}$; common between 5 and $18 \mathrm{~m}$ (Gomon, 1995).

Worldwide Distribution: Eastern Pacific (McCosker \& Rosenblatt, 2010) from Central Baja California to the Gulf of California to northern Chile, including all the oceanic islands (Garrison, 2005), Isla del Coco (Bussing \& López, 2005) and Galápagos (Baldwin \& McCosker, 2001). 


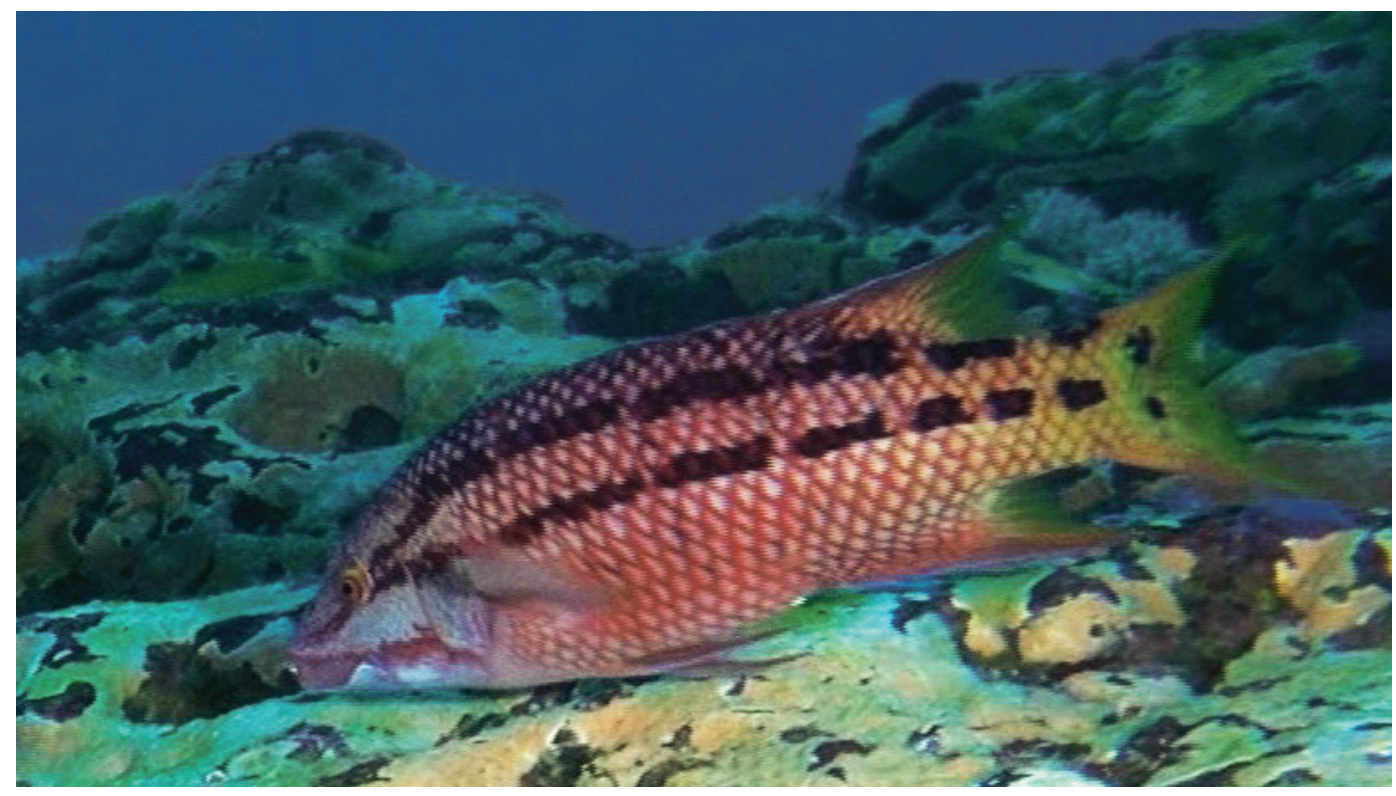

Bodianus diplotaenia at Everest (85 m), 8 August 2012.

Occurrences at Isla del Coco (This Study): 40-85 m; The Arch (60 m), afternoon; $40 \mathrm{~m}$ on the way to Everest and at Everest $(60-85 \mathrm{~m})$, morning and afternoon.

Previous RePorts from Isla del Coco: Common in shallow waters at Isla del Coco. Juveniles observed at the end of June and beginning of July (Garrison, 2005) and Fourriére et al. (2017).

REMARKS: Maximum known depth reported increased to $85 \mathrm{~m}$. 
Decodon melasma Gomon, 1974

Blackspot Wrasse / Vieja manchada

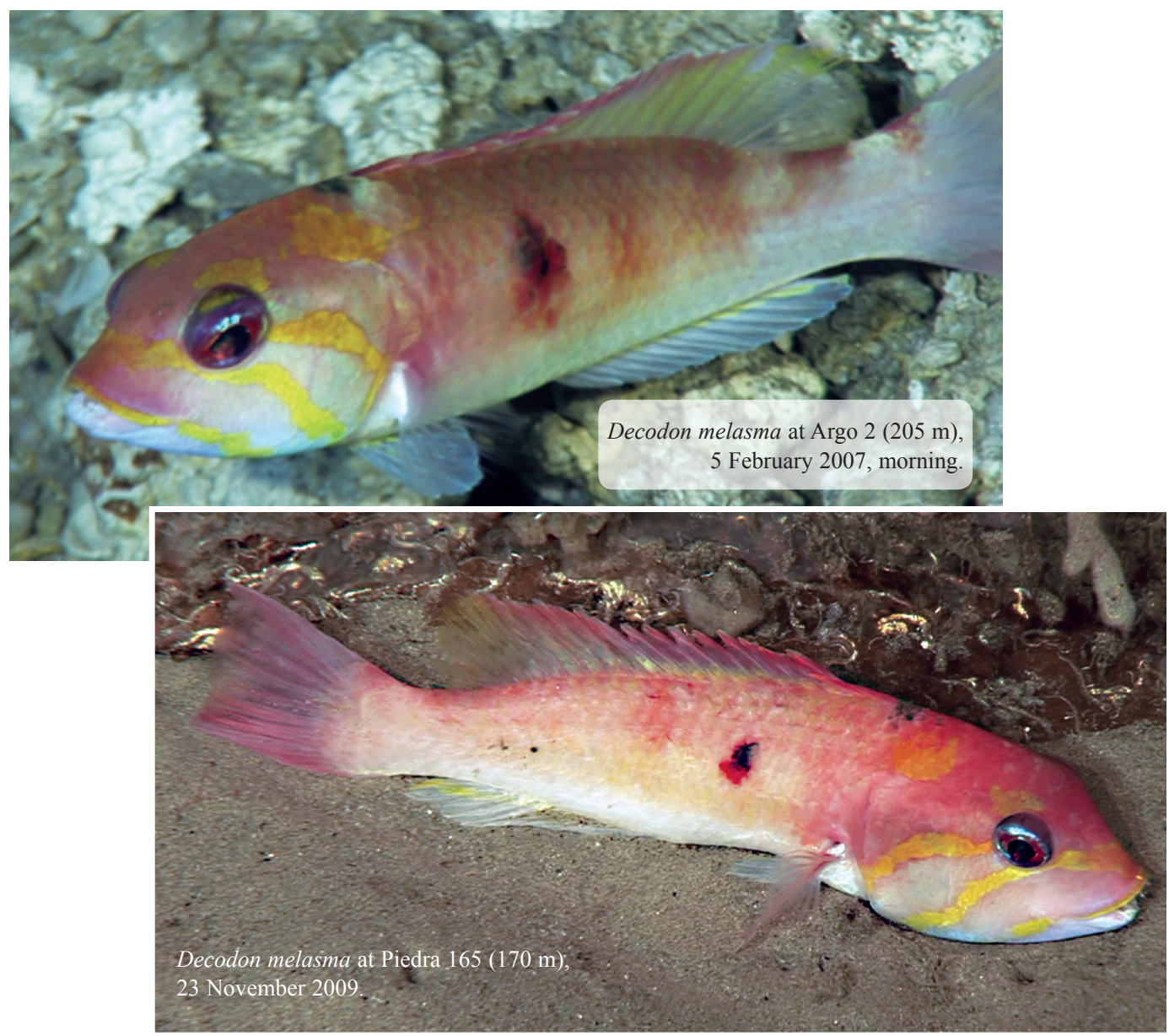

DesCriPTIOn: Body compressed, head relatively large, lateral line slightly arched (Gomon, 1995). Pink above, white below, a black spot above tip of pectoral fin and 3 yellow stripes on head (Bussing \& López, 2005). Size: 23 cm. Depth: Gomon (1995) reports 4-120 m deep. Aburto-Oropeza et al. (2010) report the occurrence of the species at 80-220 $\mathrm{m}$ at the Gulf of California.

Worldwide Distribution: Gulf of California (Lea \& Rosenblatt, 2000) to Perú and Isla del Coco and Galápagos (Baldwin \& McCosker, 2001; McCosker \& Rosenblatt, 2010).

Occurrences at Isla del Coco (This study): 150-300 m, Piedra 165 (150-170 m), The Edge (200$300 \mathrm{~m})$, Argo 2 (205 m) and The Wall 475 (300 m), morning.

Previous reports from Isla del Coco: In shallow waters (Bussing \& López, 2005) and in deep waters at more than $50 \mathrm{~m}$ (Starr et al., 2012b), and Fourriére et al. (2017).

REMARKs: Maximum depth expanded $80 \mathrm{~m}$ deeper to $300 \mathrm{~m}$. 


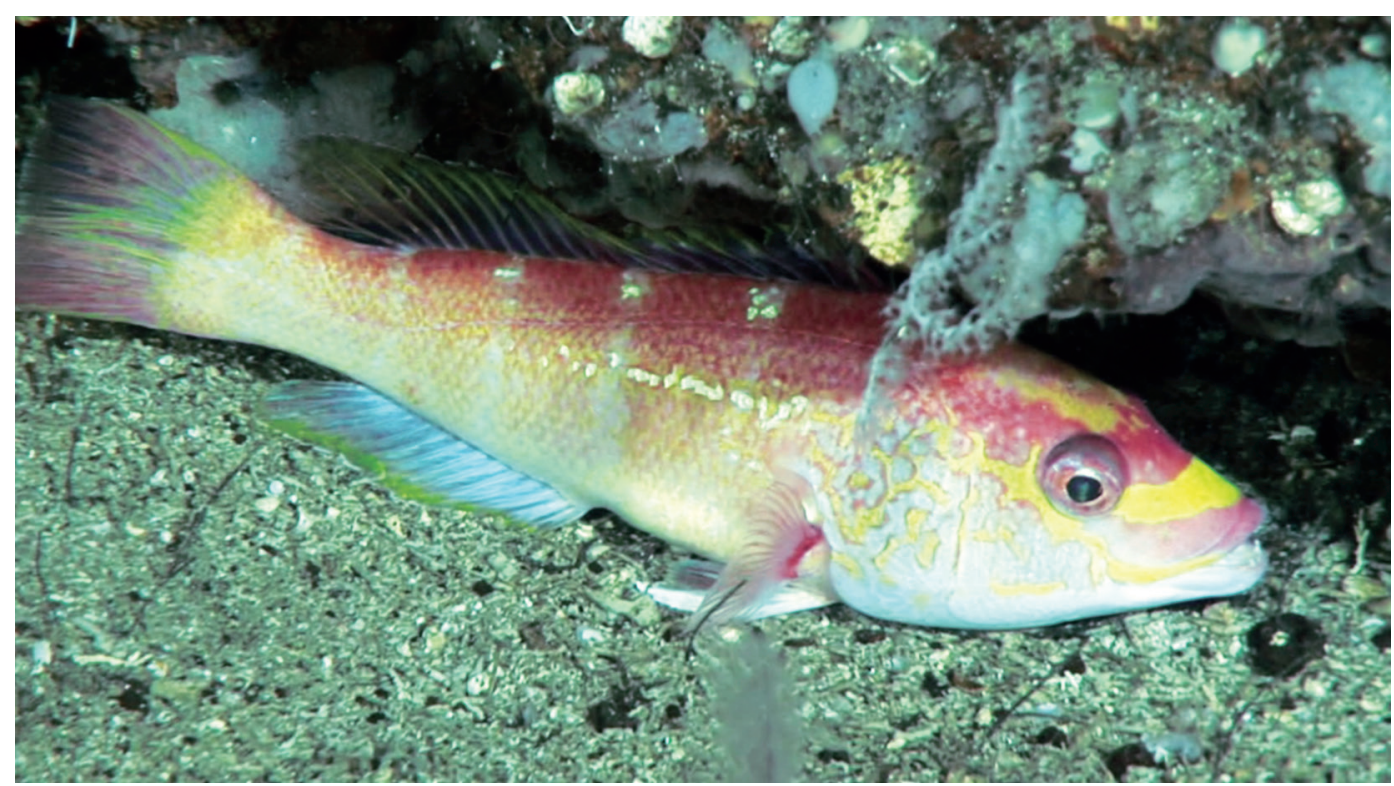

Polylepion cruentum at Las Gemelas 1 (250 m), 13 September 2009, afternoon.

DESCRIPTION: Body moderately slender, tapering markedly at rear; head large and pointed, forehead and snout profile straight except for convexity above eyes in small specimens; nape nearly straight in juveniles to moderately arched in adults (Gomon, 1977; Robertson \& Allen, 2015). Dorsal fin continuous, origin slightly anterior to a vertical at axis of pectoral fin (Gomon, 1977). Body color mostly pink; chest, belly and underside of head white; with a horizontal single stripe reaching from posterodorsal extent of opercular flap to below fourth segmented dorsal fin ray (Gomon, 1977). Head with many yellow stripes and marks, narrow black border present on dorsal side of eye (Gomon, 1977). Large oval spot on upper caudal base black in juveniles, becoming red in adults and diffuse in large individuals (Gomon, 1977). Anal fin white with distal yellow stripe, pectoral fins transparent with broad blood red band on fleshy base, pelvic fins white, membrane of spinous dorsal fin black (Gomon, 1977; Bussing \& López, 2005). Size reaches $25 \mathrm{~cm}$, depth range: 150-200 m (Robertson \& Allen, 2015).

Worldwide Distribution: Baja California to Colombia, including Isla del Coco (Bussing \& López, 2005; Robertson \& Allen, 2015). 


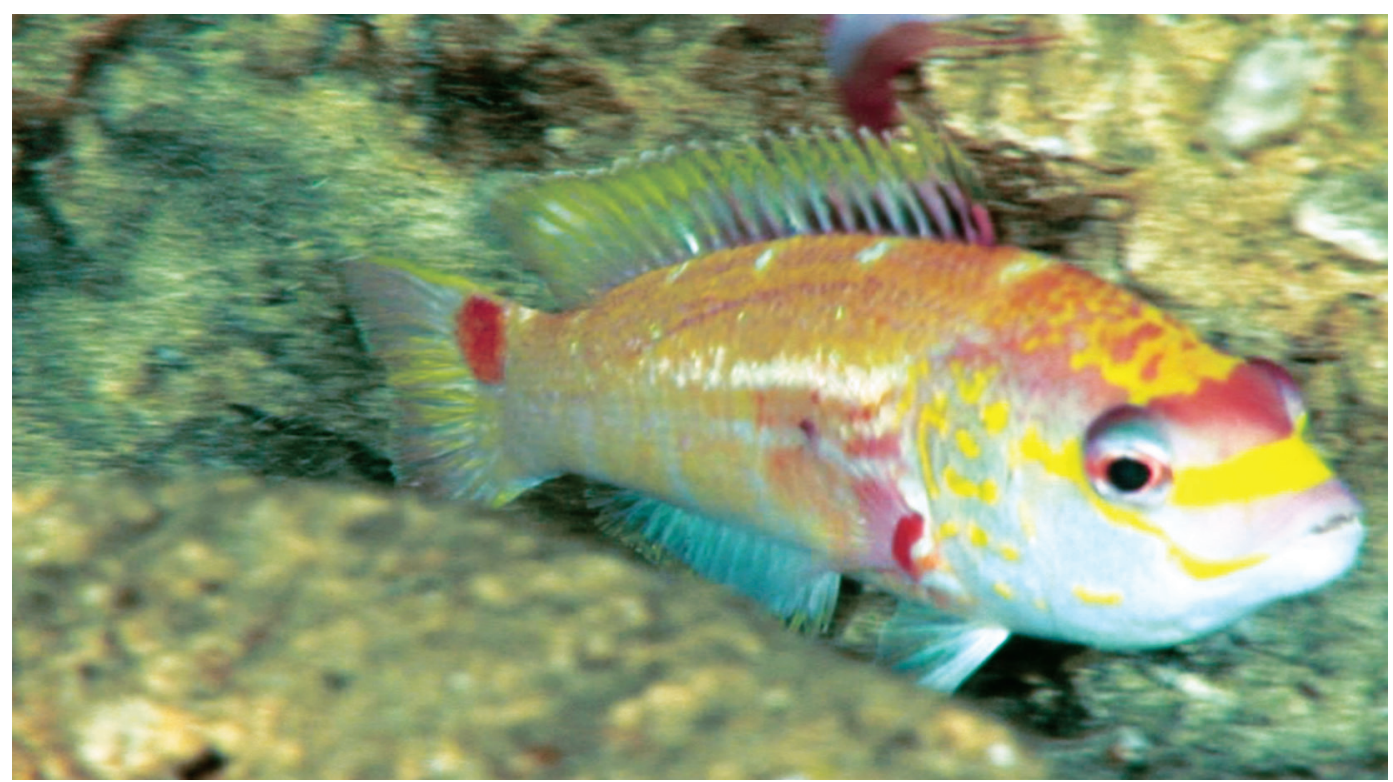

Polylepion cruentum at Everest (80 m), 12 September 2009, afternoon.

Occurrences at Isla del Coco and Las Gemelas Seamount (This study): 80-305 m; Everest (80 m) and The Wall 475 (305 m), morning; Las Gemelas 3 (163-182), Piedra 165 (170 m), Las Gemelas $1(250 \mathrm{~m})$ and Piedra Drop (300 m), afternoon.

Previous Reports from Isla del Coco: Bussing and López (2005), Robertson and Allen (2015), and Fourriére et al. (2017).

ReMARKS: Maximum depth increased by $105 \mathrm{~m}$, new maximum depth record is $305 \mathrm{~m}$. Minimum depth decreased from 150 to $80 \mathrm{~m}$. 
Family Uranoscopidae

Kathetostoma averruncus Jordan \& Bollmann, 1890

Smooth Stargazer / Miracielo buldog

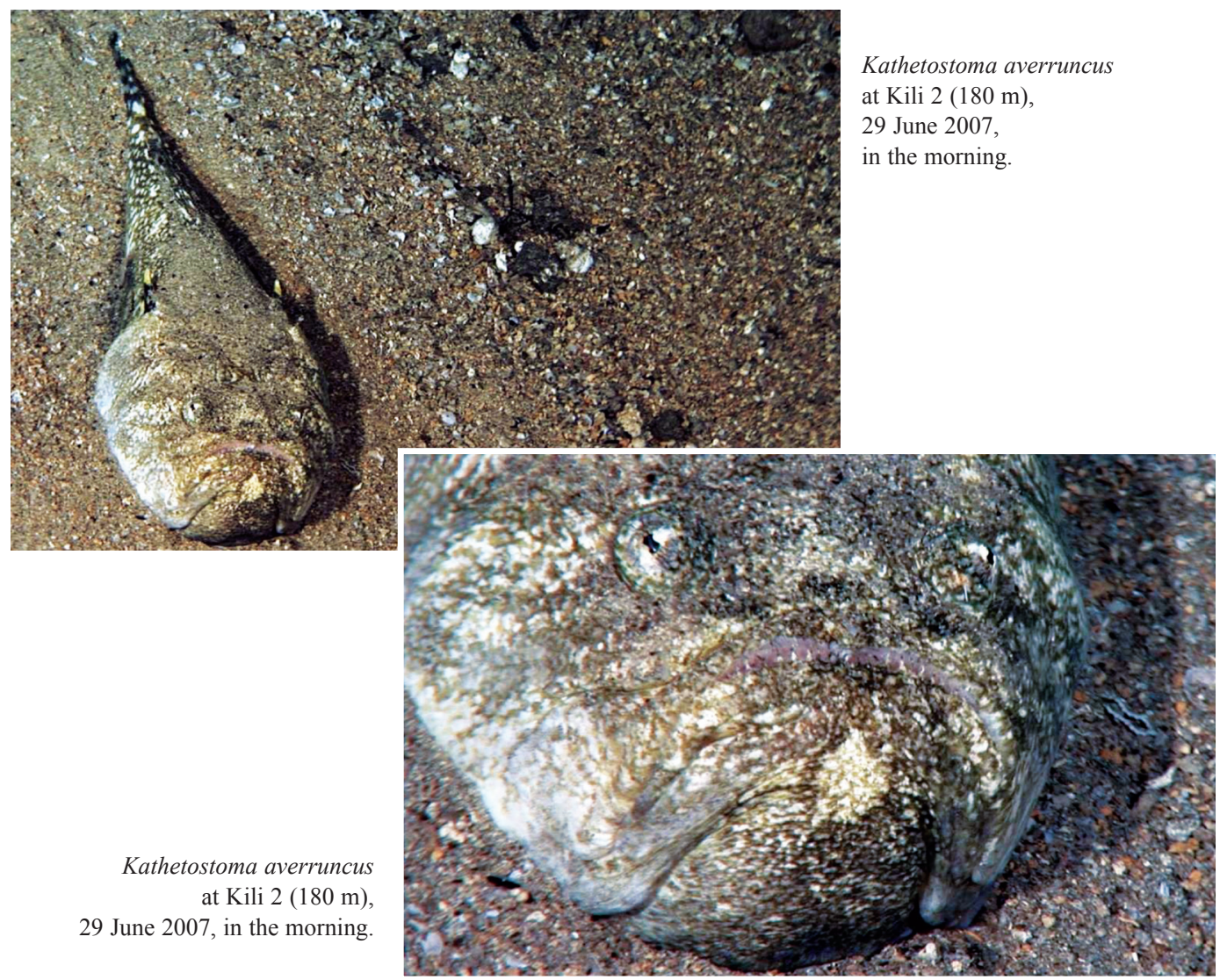

DESCRIPTION: Body short, thick, progressively becoming more compressed posteriorly; head broad, high, hard and heavily boned, eyes placed anteriorly and somewhat dorsally, mouth large, strongly oblique to vertical (Bussing \& Lavenberg, 1995b). Color black, greenish-brown to grey above, paler below; tips of the opercular spines yellowish; white dots on head; white spots and blotches on body, and on dorsal, tail and pectoral fins (Robertson \& Allen, 2015). Kathetostoma averruncus reaches $32 \mathrm{~cm}$, and is known from a depth range of 15-600 m (Robertson \& Allen, 2015).

Worldwide Distribution: California to the mouth of the Gulf of California to Perú, and the Galápagos (McCosker \& Rosenblatt, 2010; Robertson \& Allen, 2015).

Occurrences at Isla del Coco (This study): 180-311 m; at Kili 2 (180 m), morning, and at Boulders (250-311 m), afternoon.

Previous RePorts From Isla del Coco: None.

REMARKs: This is the first report for Isla del Coco. 


\section{Family Callionymidae}

Synchiropus atrilabiatus (Garman, 1899)

Blacklip Dragonet / Dragoncillo de asta

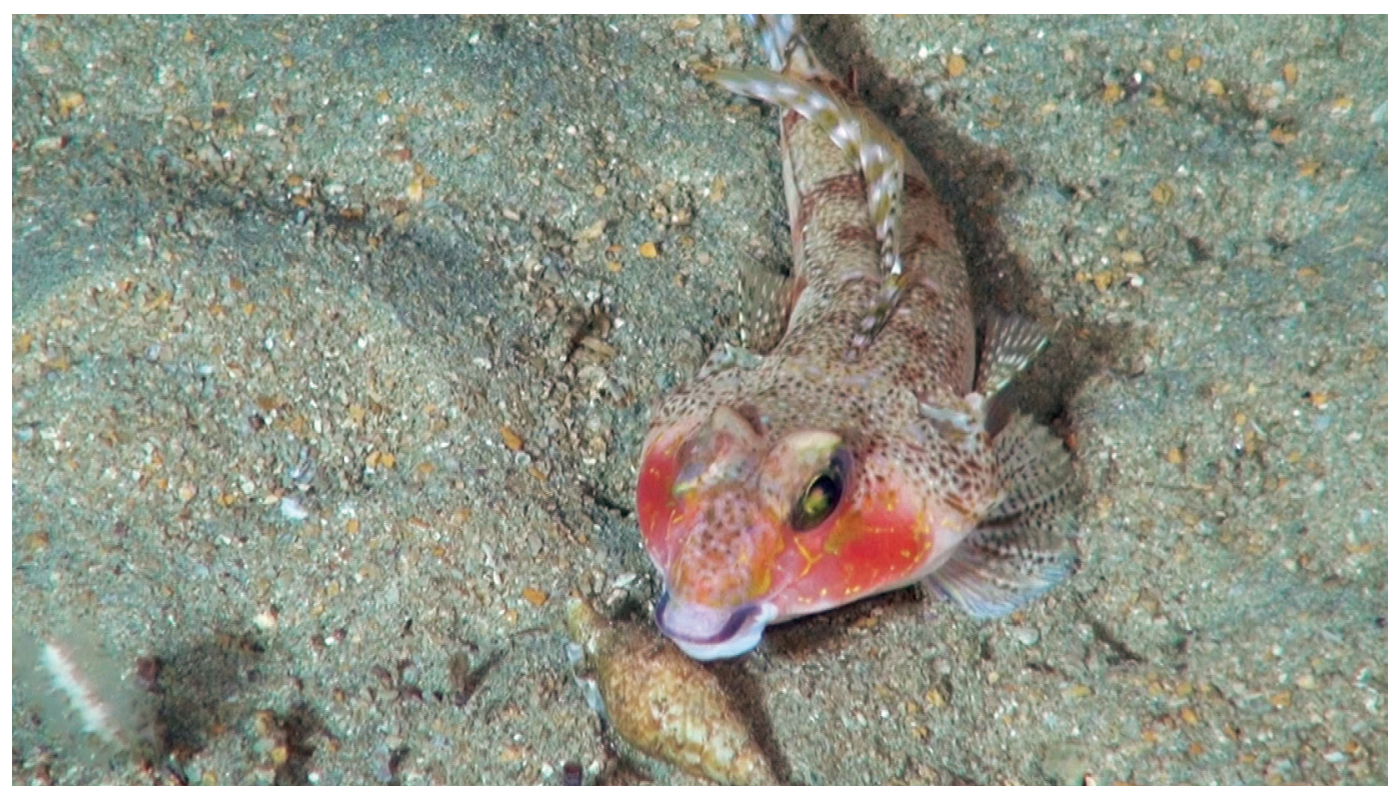

Synchiropus atrilabiatus at Piedra 165 (155 m), footage taken in 2012.

DESCRIPTION: Blacklip dragonets are found on sand, mud or rubble; have an elongate body; long and slightly depressed head; eyes large, on top of head; mouth small; preopercular spine large (Robertson \& Allen, 2015). Upper body and head red brown, with numerous small dark dots; dark oval ocellus on the anterior dorsal fin (larger and brighter in males); anal fin white, a broad red-black band near outer edge, margin white; margin of top jaw black (Robertson \& Allen, 2015). Size: 12 cm. Depth: 3-235 m, usually deeper than $40 \mathrm{~m}$ (Robertson \& Allen, 2015).

Worldwide Distribution: Southern California to the mouth of the Gulf of California to Peru, also Galapagos, Cocos and Malpelo islands (Robertson \& Allen, 2015).

Occurrences at Isla del Coco (This study): At $155 \mathrm{~m}$ deep at Piedra 165.

Previous Reports from Isla del Coco: Bussing and López (2005) and reported by Fourriére et al. (2017) as a deep-water species. 


\section{Family Gobiidae}

Lythrypnus cobalus Bussing, 1990

Cocos Blue Banded Goby / Gobio pícaro

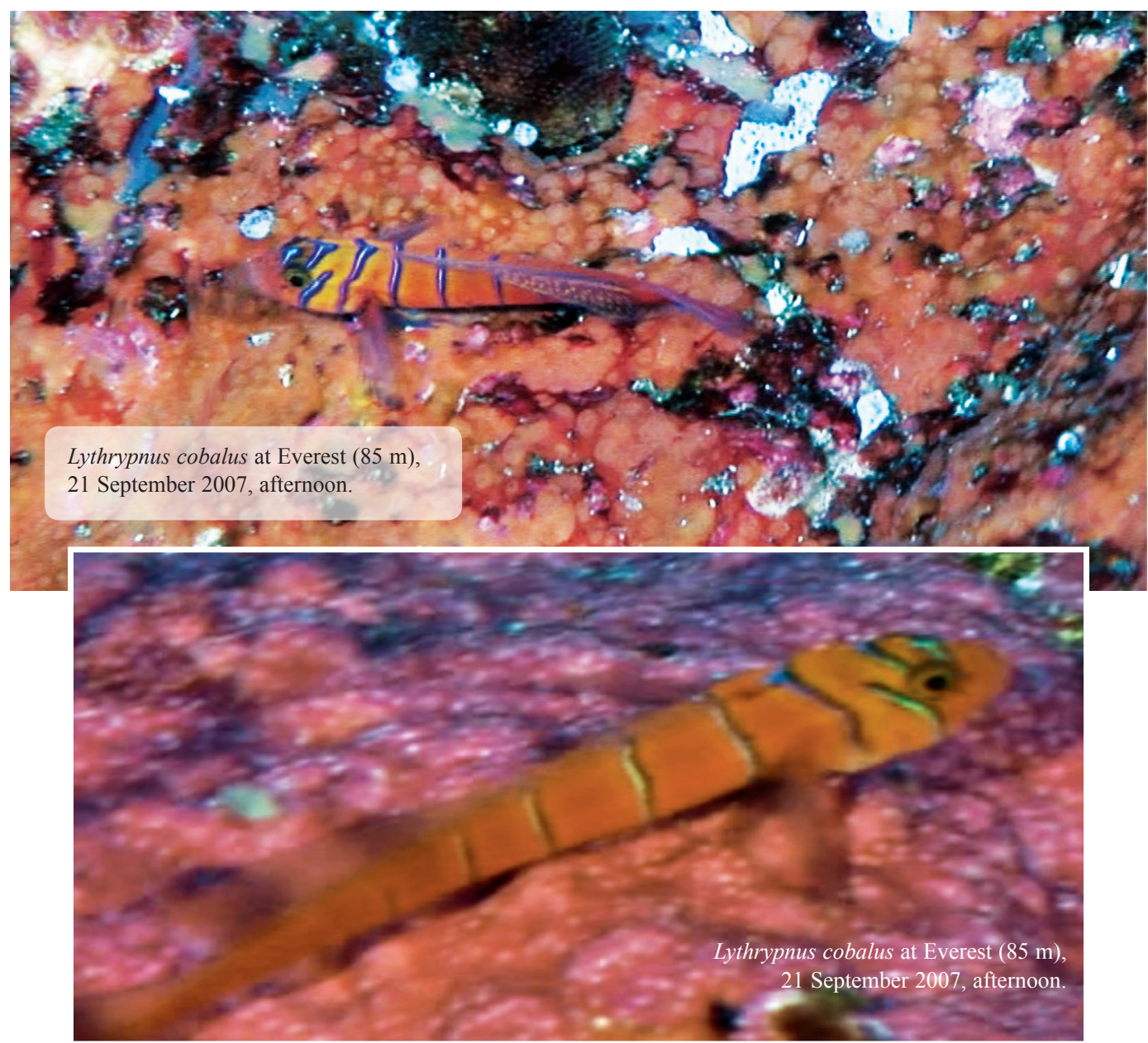

DESCRIPTION: Head and body orange-red with blue dark-edged crossbars, laterally compressed (Bussing, 1990). First dorsal fin spines are long (Garrison, 2005). Head without pores; nape without predorsal scales (Hoese, 1995); dorsal, tail and anal fins orange; pectoral and pelvic blue-grey. Size: $2.6 \mathrm{~cm}$. Depth: 30-93 m (Bussing, 1990).

Worldwide Distribution: Species endemic to Isla del Coco (Garrison, 2005).

Occurrences at Isla del Coco (This study): At Everest 60-90 m, morning and afternoon.

Previous reports from Isla del Coco: At Bahía Chatham (Bussing, 1990) and Alcyone, Roca Sucia, Roca Aleta de Tiburón, Manuelita, Roca Sumergida (Garrison, 2005), and Fourriére et al. (2017).

REMARKS: In deep waters observed only at Everest. 


\section{Family Acanthuridae}

Prionurus laticlavius (Valenciennes, 1846)

Razor Surgeonfish / Cochinito barbero

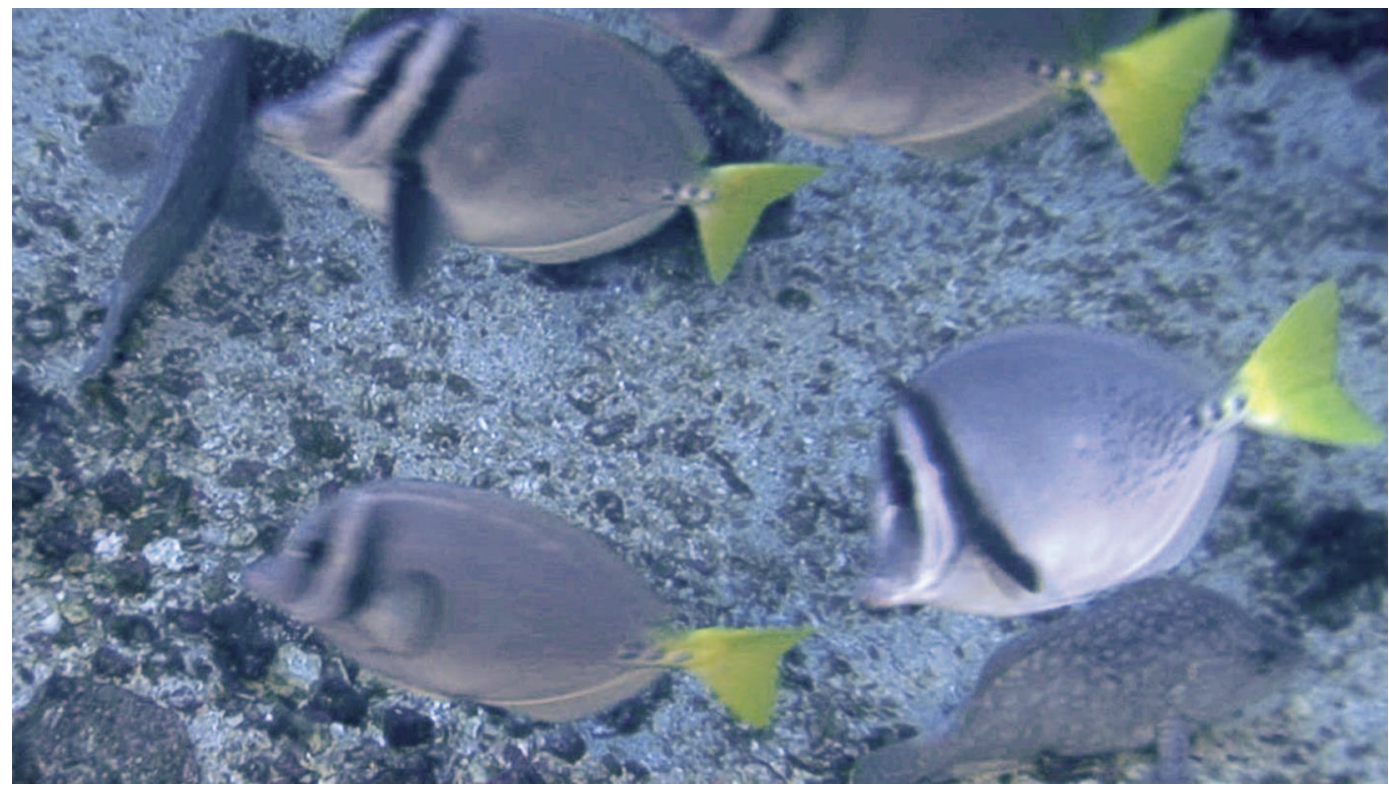

Prionurus laticlavius at Bajo Manuelita (65 m), 18 December 2006, afternoon.

DESCRIPTION: Body oval and compressed. Dorsal fin with 27 branched rays, plain gray body, with three pairs of bony plates with cutting keels along middle of tail base. Snout pointed, small protrusible mouth. Up to $32 \mathrm{~cm}$. Depth range: Inhabits shallow waters and forms large schools (Krupp \& Schneider, 1995). Depth: 0-30 m (Robertson \& Allen, 2015).

Worldwide Distribution: From the Southwest Gulf of California to Ecuador, including Galapagos Islands, Isla del Coco, Malpelo, Revillagigedo and some places around the mouth of the Gulf of California (Robertson \& Allen, 2015).

Occurrences at Isla del Coco (This study): 40-65 m at Bajo Manuelita, afternoon.

Previous Reports from Isla del Coco: Starr et al. (2012b) reported this species at more than a 50 $\mathrm{m}$ at Isla del Coco. Reported by Fourriére et al. (2017) from shallow waters.

REMARKs: The known maximum depth reported by Robertson and Allen (2015) is increased by 35 $\mathrm{m}$, to $65 \mathrm{~m}$. 
Family Trichiuridae

Trichiuridae, unidentified

Cutlassfish / Peces sable o cinta

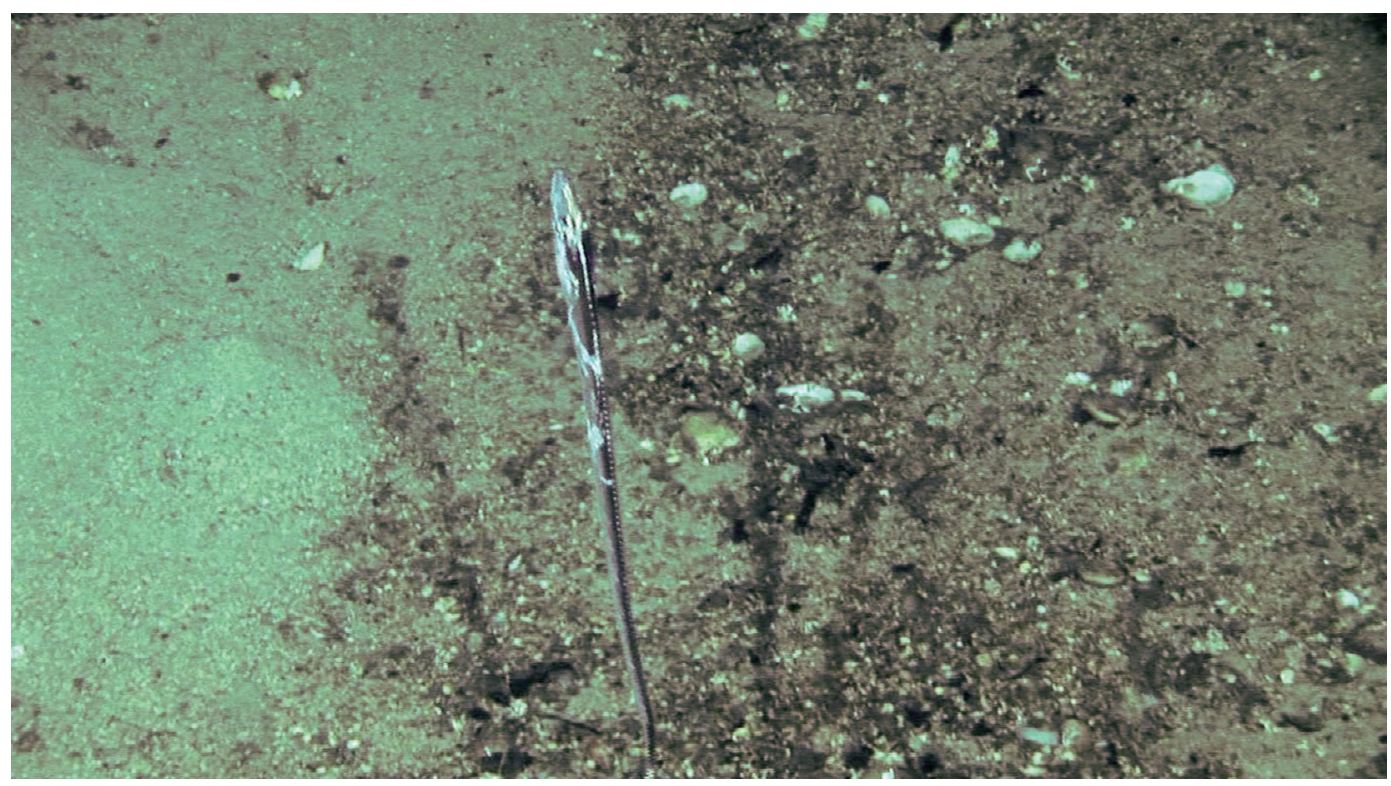

Trichiuridae, unidentified at The Wall 475 (300 m), 30 December 2009, afternoon.

DesCriPTION: Cutlassfishes are large fishes (1-2 m) with thin ribbon-like bodies. They have a large mouth, dorsal and anal fins extremely long-based and low (Robertson \& Allen, 2015). It is necessary to examine the caudal fin for proper identification. The genus Trichiurus has no caudal fin, while Lepidopus has (Nakamura, 1995). Our images are not sufficient to determine the genus.

WorLDWide Distribution: The family occurs in all temperate and tropical seas.

Occurrences at Isla del Coco (This study): The Wall 475 (300 m).

Remarks: Trichiurus lepturus is circumglobal and is known in the Eastern Tropical Pacific from California to Peru and the Galápagos Islands. Lepidopus manis is known only from Galápagos, Lepidopus caudatus has widespread distribution and Lepidopus tenuis is a circumglobal species (Robertson \& Allen, 2015; Eschmeyer et al., 2017). 


\section{ORDER PLEURONECTIFORMES \\ Family Bothidae \\ Bothus mancus (Broussonet, 1782)}

Tropical Flounder / Lenguado tropical

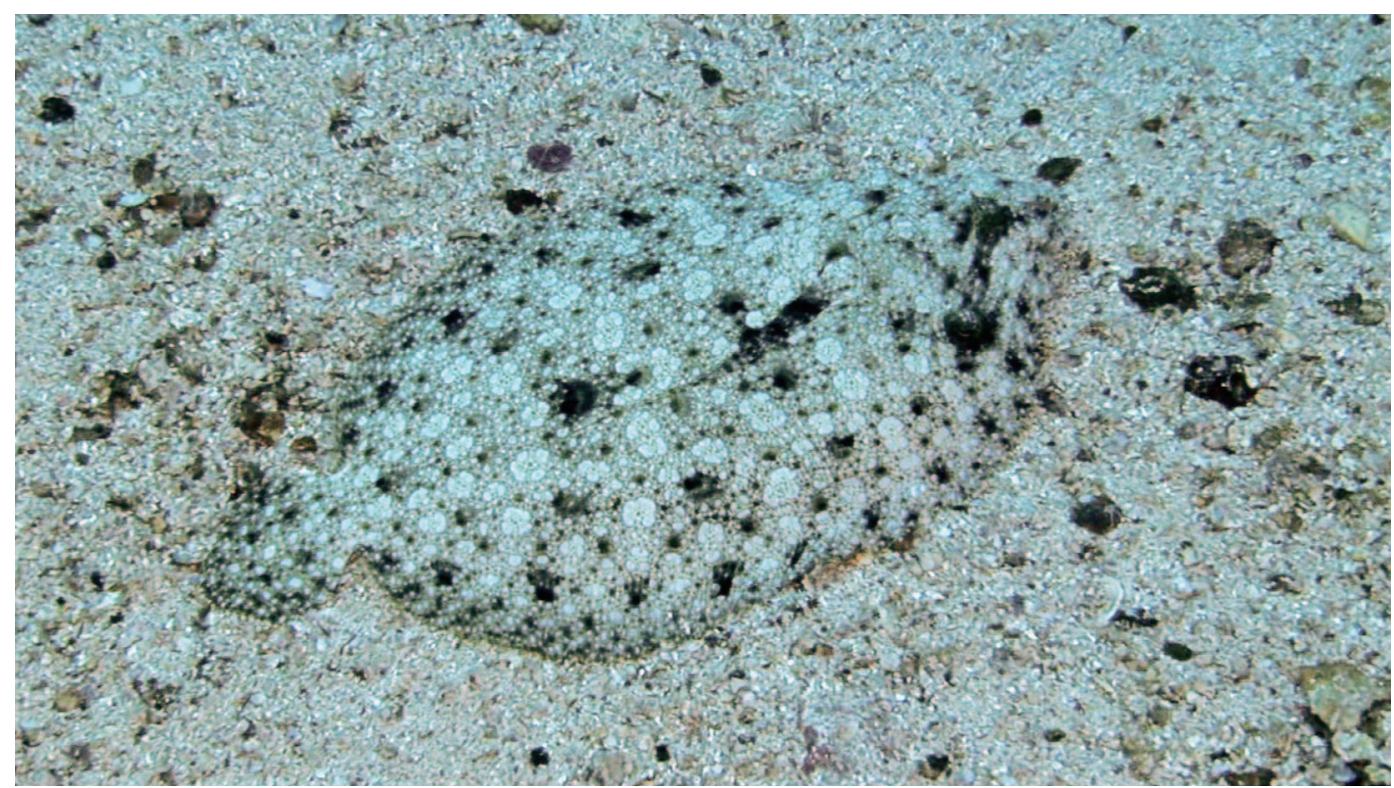

Bothus mancus at Bajo Manuelita (50 m), 28 August 2007, afternoon.

DesCRIPTION: Eyes on left side of head, wide and flat between eyes, much wider eye in males; lower eye well before upper eye; male with very elongate pectoral fin on eyed side (Robertson \& Allen, 2015). Color brown with numerous white to pale blue spots, some of them forming partial circles; dark brown spots also present; three dark blotches along lateral line (Robertson \& Allen, 2015). Size: reaches $42 \mathrm{~cm}$, depth: 0-150 m (Robertson \& Allen, 2015).

Worldwide Distribution: Tropical Indo-Pacific, Panamá, Costa Rica, the mouth of the Gulf of California; the Revillagigedos, Clipperton, Isla del Coco, Malpelo and Galapagos (Bussing \& López, 2005; Robertson \& Allen, 2015).

ocCurRences at IsLa del Coco: Bajo Manuelita (40-60 m).

Previous Reports from Isla Del Coco: Bussing and López (2005), and by Fourriére et al. (2017) as a deep-water species. 


\section{Family Cynoglossidae}

Symphurus diabolicus Mahadeva \& Munroe, 1990

Devil's Tonguefish / Lengua diabólica

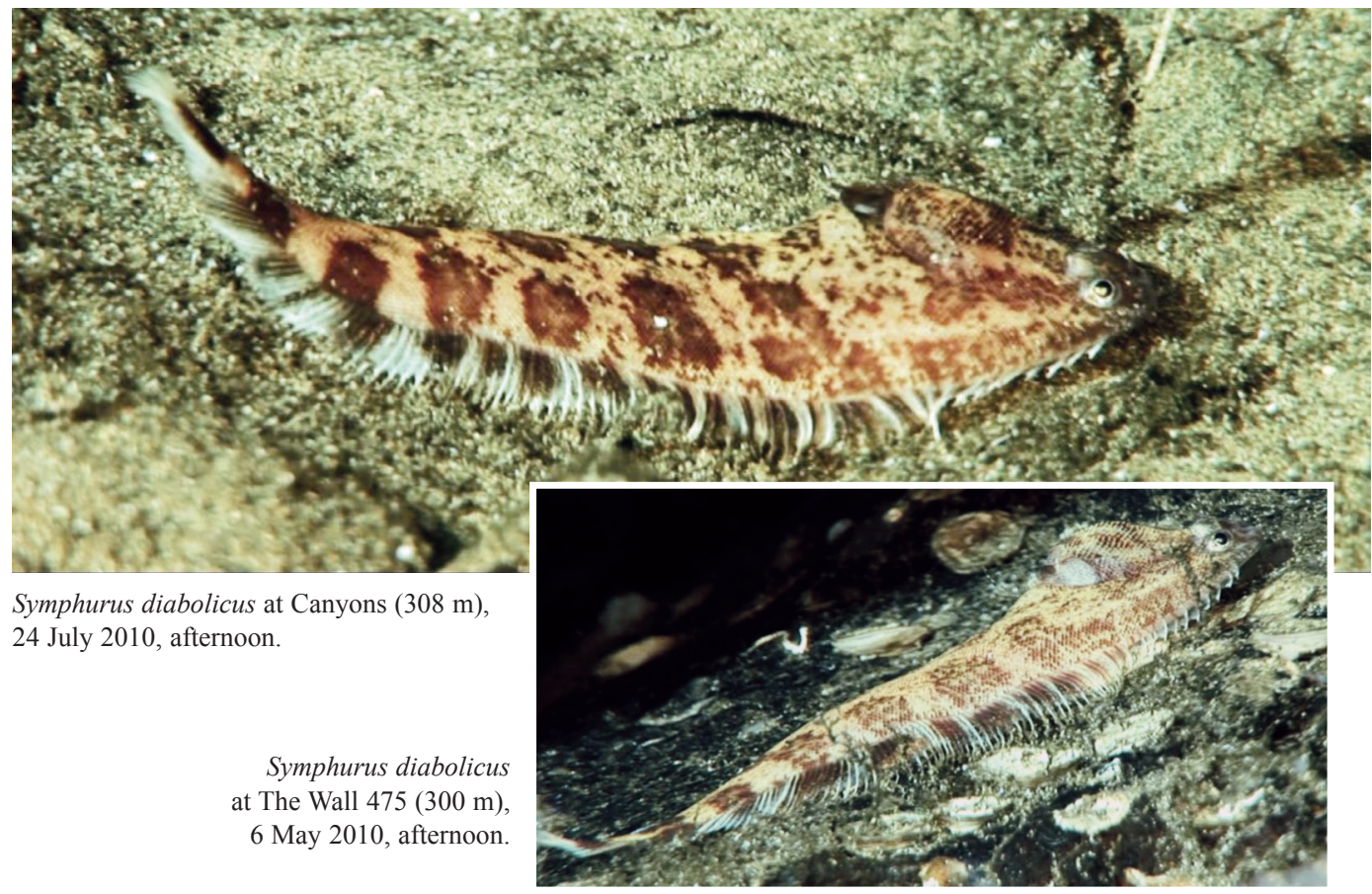

DESCRIPTION: Solid olive green or brown with dark rectangular blotches along body and at the bases of the dorsal and anal fins. Dorsal and anal fins with dark blotches. Elongate body; narrow head with pointed snout. No pupillary operculum; large, prominent eyes, with migrated eye near dorsal margin of head. Size: reaches around $12.5 \mathrm{~cm}$. Relatively common (captured for research) at depths of 308 to $757 \mathrm{~m}$, observed as shallow as $245 \mathrm{~m}$ (Munroe \& McCosker, 2001).

WorLDWIDE DISTRIBUTION: Observations and captures from submersibles showed this species is common in deep waters at the Galápagos (Munroe \& McCosker, 2001).

Occurrences at Isla del Coco (This study): 250-316 m, Canyons (308 m) and The Wall 475 (250$316 \mathrm{~m})$, morning and afternoon.

Previous RePORTS From IsLA Del Coco: This is the first published report from Isla del Coco. Reported previously by Fourriére et al. (2017) based on Robertson and Allen (2015) website, who obtained the information of the record for Isla del Coco during the preparation of the present work.

Remarks: Previously assumed to be endemic from the Galápagos (Munroe \& McCosker, 2001); this and Fourriére et al. (2017) records for Isla del Coco widens its known distribution. It was observed during the morning as well as in the afternoon. Munroe and McCosker (2001) suggest that natural light levels at greater depths are low enough such that during daytime tonguefishes do not bury themselves in the substrate until frightened, as opposed to Symphurus from shallow waters that lie buried in the substrate during daylight. 
Pleuronectiformes, unidentified

Flatfish / Lenguado

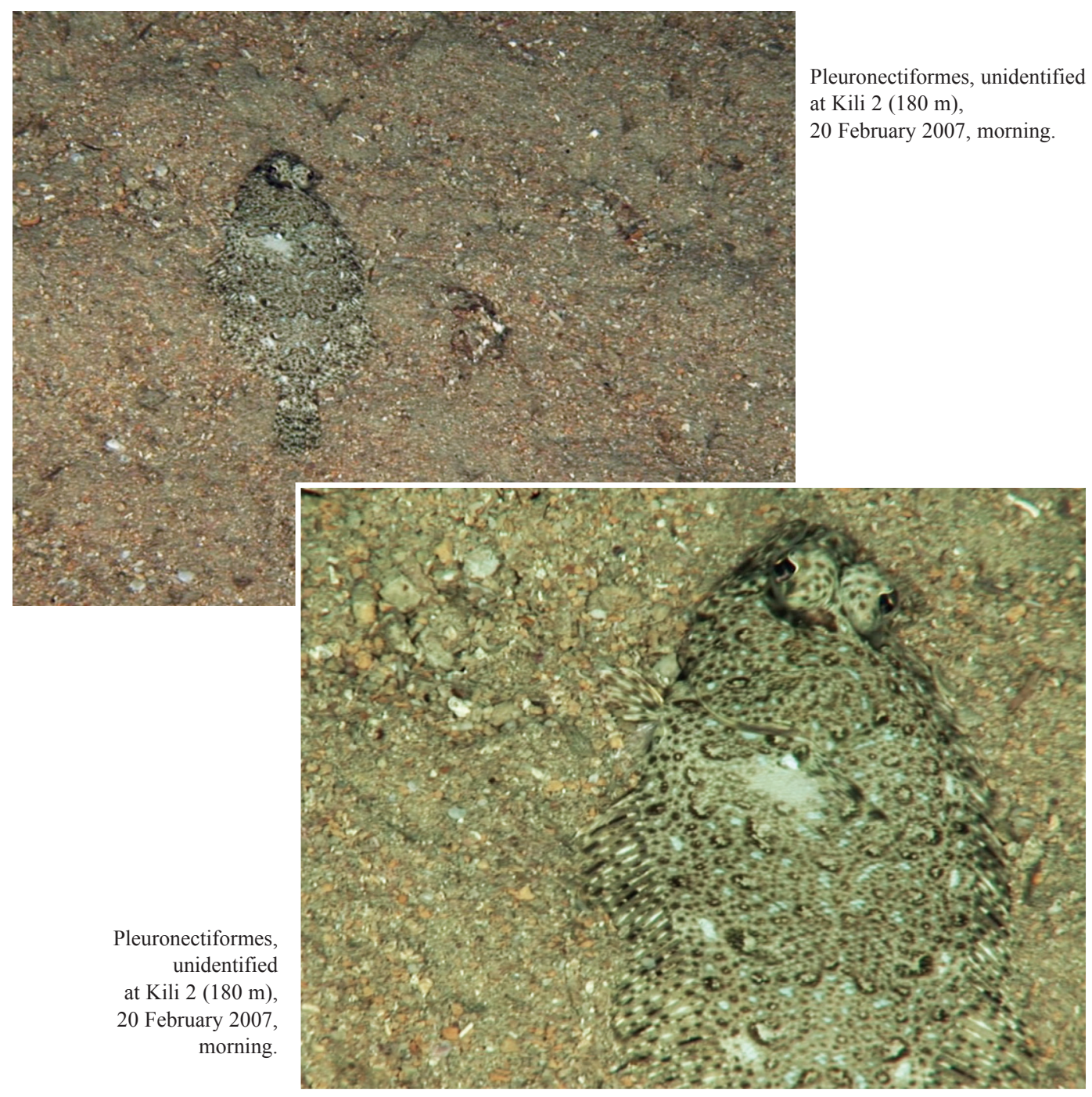

DESCRIPTION: Photographed specimens have enlarged eyes on left side of head, with a brown margin, and the eye lobules have brown spots or blotches. Body greyish brown with numerous dark brown blotches and relatively rounded whitish spots, mostly on the upper and lower part of the body on the ocular side. Light blue elongate spots and lighter rounded blotches with a dark margin all over the head and body. Dorsal, anal, caudal and pelvic fins mottled.

OCCurRences at Isla Del Coco (This study): 180-190 m, Kili $2(180 \mathrm{~m})$ and at the slope to a depth of $190 \mathrm{~m}$, morning.

Previous RePORTS FROM Isla Del Coco: An unidentified pleuronectiform individual was reported by Starr et al. (2012b) at depths greater than $50 \mathrm{~m}$. 


\section{ORDER TETRAODONTIFORMES \\ Family Tetraodontidae \\ Arothron hispidus (Linnaeus, 1758) \\ Stripebelly Puffer / Botete panza rayada}

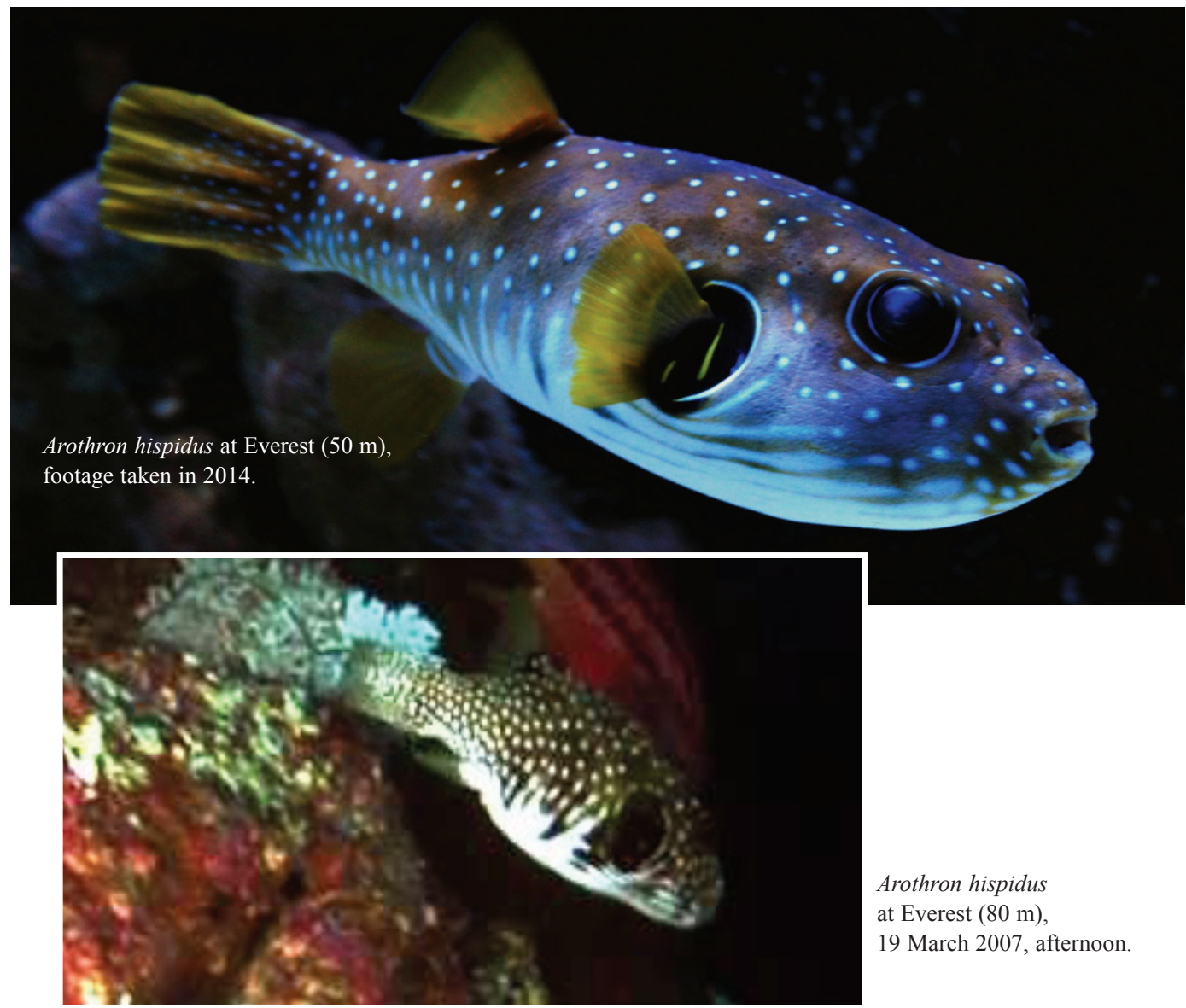

DESCRIPTION: Head and body gray with white spots vanishing ventrally, white stripes below and the ventral region; pectoral fin circled by white and black stripes (Bussing \& López, 2005). A single dorsal fin; no pelvic fins, caudal fin rounded. Size: reaches $50 \mathrm{~cm}$. Depth: 1-90 m (Robertson \& Allen, 2015).

Worldwide distribution: Eastern Pacific, Baja California to Colombia; also, western Pacific (Bussing, 1995) and Indo-Pacific (Garrison, 2005).

Occurrences at Isla Del Coco (This Study): 10-80 m, descending to Everest and at Everest (45-80 m) morning and afternoon.

Previous Reports from Isla del Coco: From $6 \mathrm{~m}$ to depths of at least $40 \mathrm{~m}$ (Bussing \& López, 2005); in shallow waters at Bahía Chatam, Roca Sucia, Manuelita, Punta María, Roca Aleta de Tiburón and Ulloa (Garrison, 2005), and by Fourriére et al. (2017) as a shallow water species. 

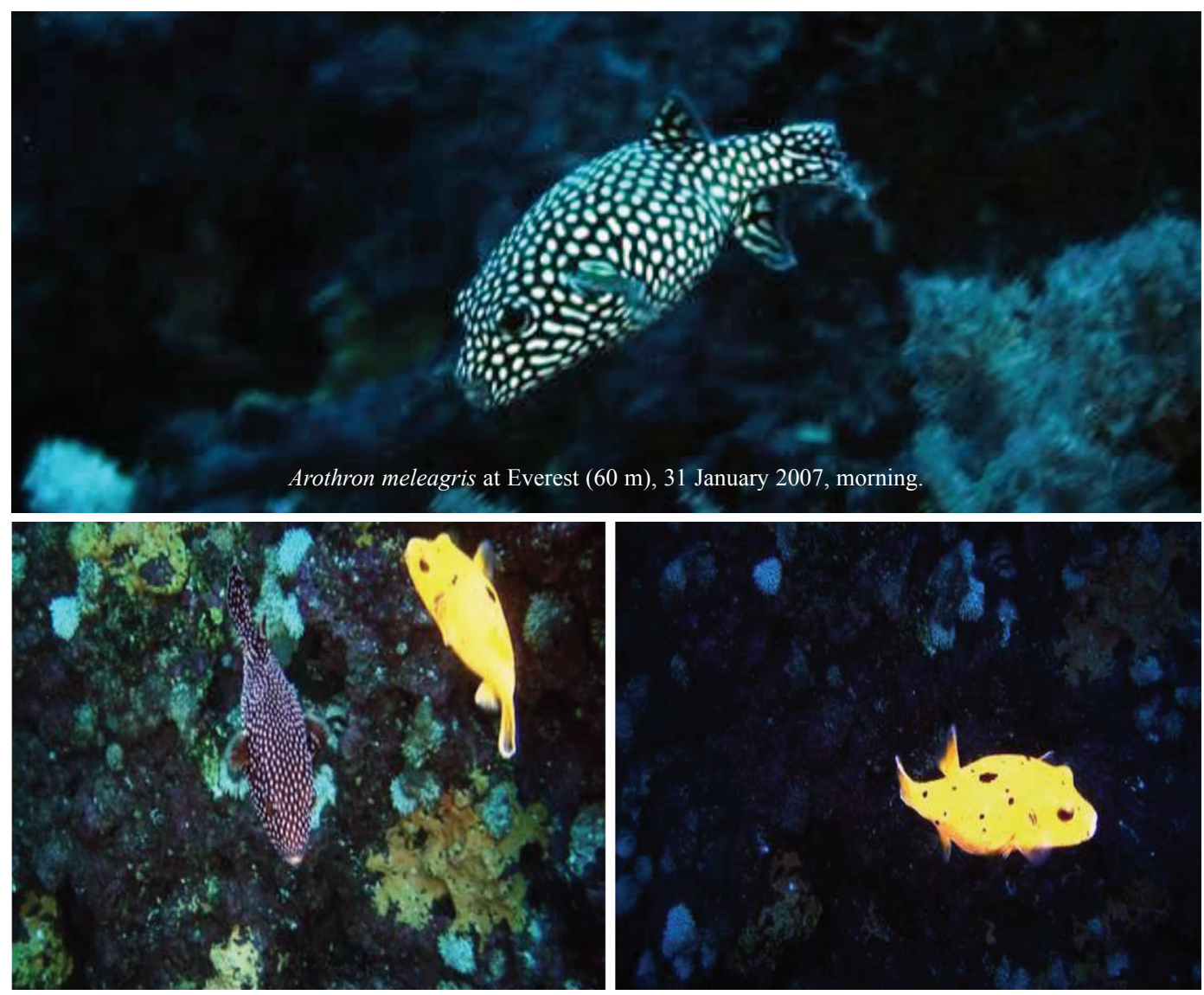

Left, Arothron meleagris two color phases at Everest (60 m), 11 February 2007, morning. Right, A. meleagris yellow phase, at Everest (80 m), 11 February 2007, morning.

DESCRIPTION: Head, body and all fins black with white dots in the spotted phase, or yellow (Bussing \& López, 2005; Garrison, 2005) with a few black spots in the golden phase (Garrison, 2005). Body robust, capable of inflation by taking in water or air (Bussing, 1995), tail rounded, mouth beak-like and terminal (Garrison, 2005). Depth: 1-73 m (Randall \& Cea, 2011).

Worldwide Distribution: Tropical Indo-Pacific and Eastern Tropical Pacific, from México to Ecuador, including all oceanic islands (Bussing, 1995; Garrison, 2005).

Occurrences at Isla del Coco (This study): 10-80 m, descending to Everest and at Everest (45-80 $\mathrm{m})$, morning; at Bajo Manuelita (55 m), afternoon.

Previous RePorts From Isla Del Coco: Bussing and López (2005), common in shallow waters from $1 \mathrm{~m}$ to at least $20 \mathrm{~m}$ (Garrison, 2005), and by Fourriére et al. (2017) as shallow water species.

REMARKs: Known maximum depth increases from $73 \mathrm{~m}$ to $80 \mathrm{~m}$. 
Oceanic Puffer / Botete oceánico

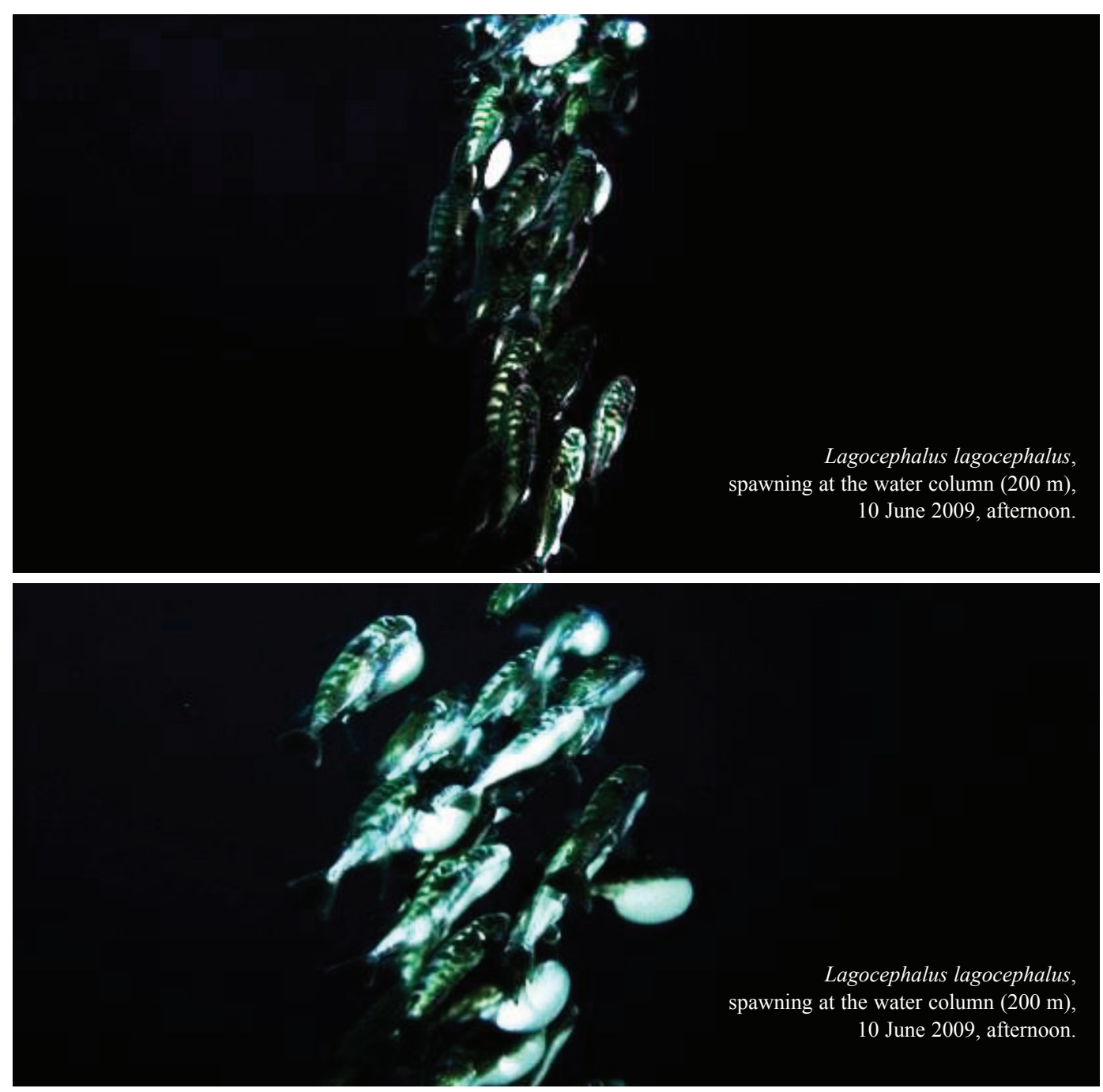

DESCRIPTION: Elongate body with tough scaleless skin, flanks silver with black spots, white ventrally. Upper body and head dark green, brownish gray or dark blue; fins dark. Size: $61 \mathrm{~cm}$ (Robertson \& Allen, 2015). Depth: 0-475 m (Robertson \& Allen, 2015).

WORLDWIDE DISTRIBUtion: Circumtropical; California to Ecuador and oceanic islands (Robertson \& Allen, 2015).

Occurrences at Isla del Coco (This study): From the surface to $200 \mathrm{~m}$ at the water column on the north side of the island, at Everest and The Wall 475, in the afternoon.

Previous RePORTS from IsLA DEL Coco: Robertson and Allen (2015) report this species for the oceanic islands of the Eastern Tropical Pacific, and by Fourriére et al. (2017) as shallow water species. 


\section{Family Diodontidae}

Chilomycterus reticulatus (Linnaeus, 1758)

Spotfin Burrfish / Pez erizo enano

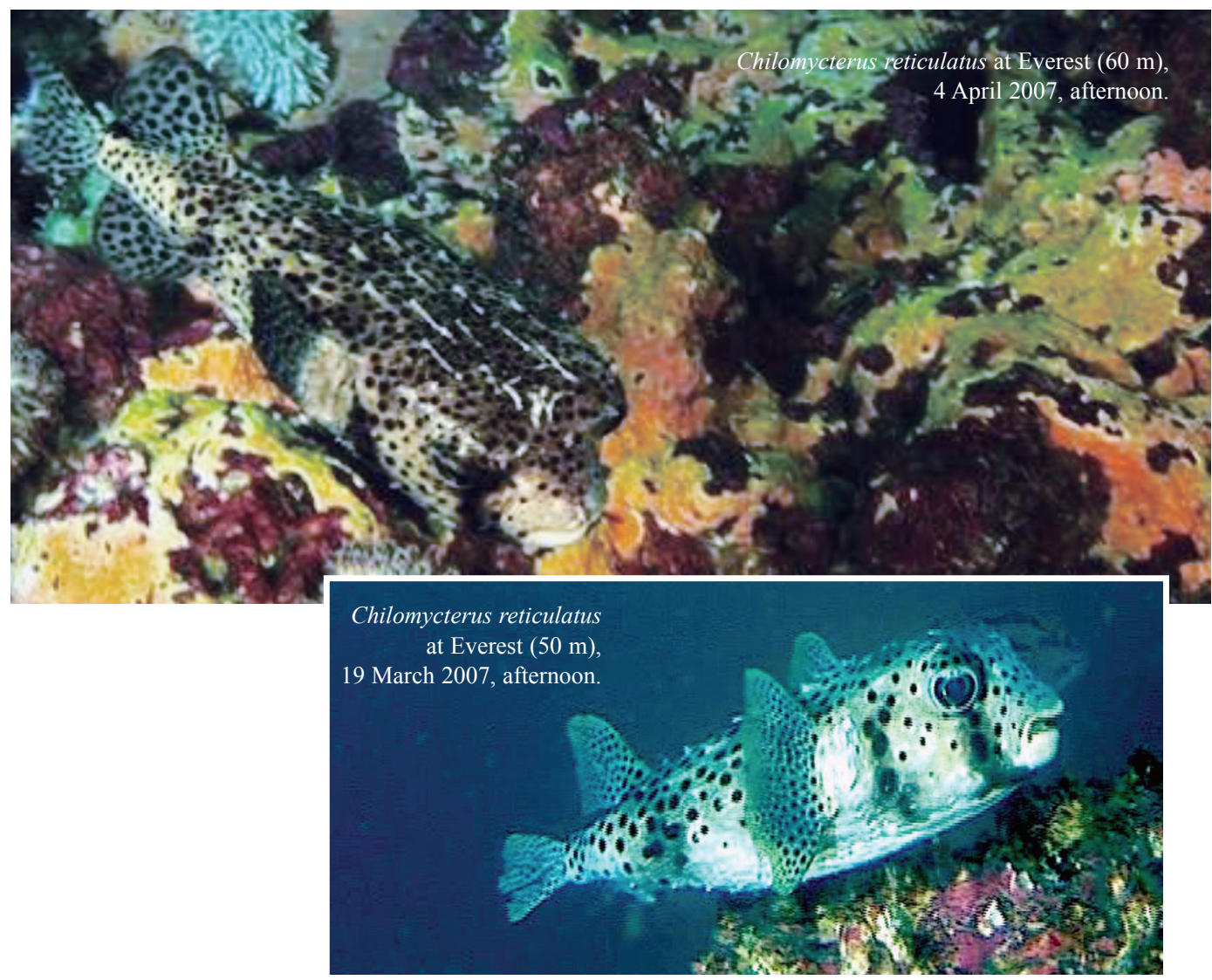

DeSCRIPTION: Small spine dorsally on caudal peduncle; no tentacles over eyes (Leis, 2007). No movable spines; body covered with black spots (Bussing \& López, 2005). Dusky brown bars on head and body. Dorsal and anal fins small; pelvic fin absent (Garrison, 2005). Size: grows to about 75 cm. Depth: to $141 \mathrm{~m}$ (Robertson \& Allen 2015).

WORLDWIDE DISTRIBUTION: Circumtropical and with a largely temperate distribution (Garrison, 2005; Leis, 2007). In the Eastern Tropical Pacific from California to Chile (Garrison, 2005, Robertson \& Allen, 2015).

Occurrences at Isla del Coco (This study): Everest (45-60 m), afternoon and morning.

Previous Reports from Isla del Coco: At Isla del Coco (Bussing \& López, 2005), $6 \mathrm{~m}$ to at least $36 \mathrm{~m}$, sightings at practically every site in shallow waters (Garrison, 2005), and by Fourriére et al. (2017) as shallow water species.

Remarks: Maximum depth reported by Garrison (2005) for this species at Isla del Coco is now almost doubled, to $60 \mathrm{~m}$. 